\title{
A NEOSARTORYA FISCHERI ANTIFUNGÁLIS PROTEIN 2 (NFAP2) IZOLÁLÁSA ÉS JELLEMZÉSE
}

\author{
DOKTORI ÉRTEKEZÉS \\ TÓTH LILIÁNA
}

\section{TÉMAVEZETŐK:}

DR. GALGÓCZI LÁSZLÓ

TUDOMÁNYOS MUNKATÁRS

PROF. DR. VÁGVÖLGYI CSABA

TANSZÉKVEZETŐ EGYETEMI TANÁR

\section{BIOLÓGIA DOKTORI ISKOLA}

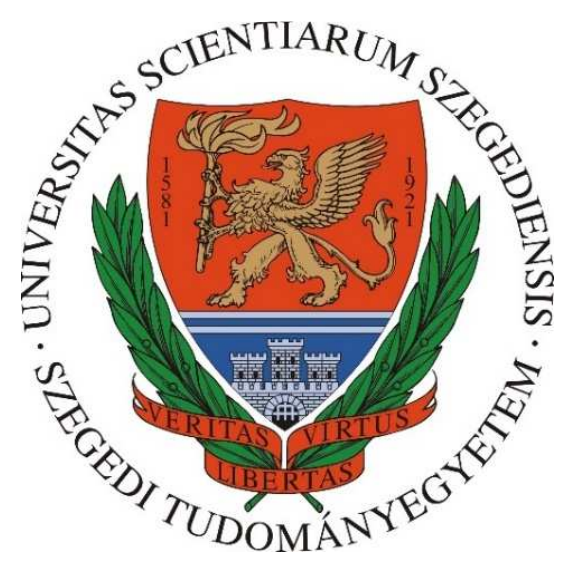

SZEGEDI TUDOMÁNYEGYETEM TERMÉSZETTUDOMÁNYI ÉS INFORMATIKAI KAR MIKROBIOLÓGIAI TANSZÉK

\section{SZEGED}




\section{TARTALOMJEGYZÉK}

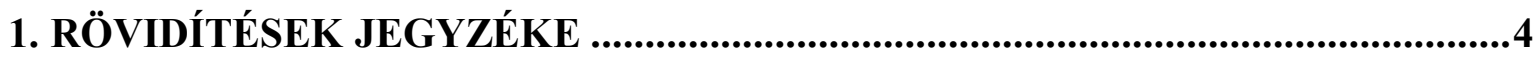

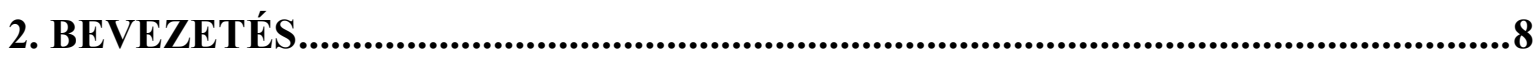

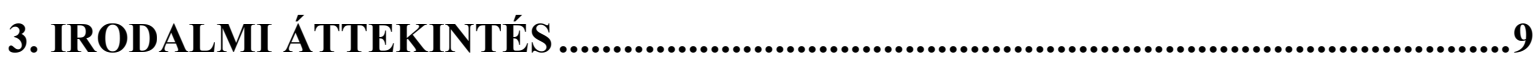

3.1. A Candida nemzetség klinikai jelentősége...............................................................9

3.1.1. A Candida fertőzések kezelése.........................................................................11

3.1.2. Azol és echinokandin rezisztencia kialakulása klinikai Candida

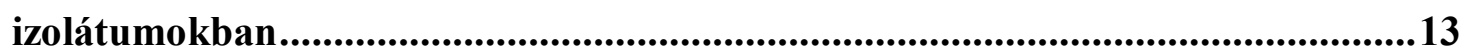

3.2. A fonalas tömlösgombák ciszteinben gazdag antifungális fehérjéi......................14

3.2.1. A cgAFP-k szerkezete, a szerkezet és hatásmechanizmus összefüggése......18

3.2.2. A cgAFP-k hatásmechanizmusa ....................................................................21

3.2.3. A cgAFP-k antifungális spektruma ..............................................................24

3.2.4. A cgAFP-k alkalmazási lehetőségei .................................................................25

3.2.5. A cgAFP-k heterológ expressziója ...................................................................28

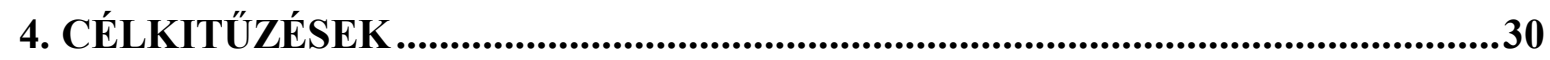

5. ANYAGOK, ESZKÖZÖK ÉS MÓDSZEREK ...................................................32

5.1. A kísérletek során alkalmazott mikroorganizmusok ............................................32

5.2. Alkalmazott tápközegek és tenyésztési körülmények...........................................32

5.2.1. Tápközegek ......................................................................................................32

5.2.2. Tenyésztési körülmények .............................................................................34

5.3. Alkalmazott pufferek és oldatok ......................................................................35

5.4. Alkalmazott indítószekvenciák............................................................................38

5.5. Alkalmazott módszerek .........................................................................................38

5.5.1. NFAP2 izolálása és azonosítása .............................................................38

5.5.1.1. Fehérjetermelés..........................................................................................38

5.5.1.2. Az NFAP2 tisztítása ...............................................................................39

5.5.1.3. NFAP2 tisztítás ellenőrzése..................................................................39

5.5.1.4. NFAP2 sómentesítése és liofilezése ...........................................................40

5.5.1.5. Az NFAP2 koncentrációjának meghatározása .........................................40

5.5.1.6. Az NFAP2 azonosítása tömegspektrometriával.........................................40

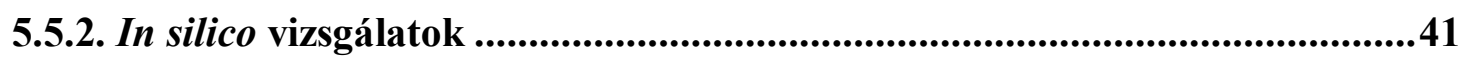

5.5.3. Az NFAP2 és homológ proteinek filogenetikai analízise.................................41

5.5.4. Az rNFAP2-termelő $P$. chrysogenum-alapú heterológ expressziós rendszer

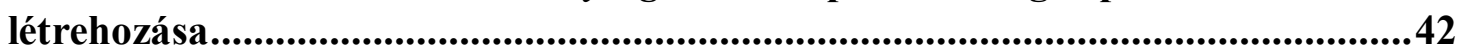


5.5.4.1. Az érett NFAP2-t kódoló gén pSK275paf vektorba történő klónozása.42

5.5.4.2. A P. chrysogenum $\Delta p a f$ törzs transzformációja a pSK275nfap2 plazmiddal

5.5.4.3. Az NFAP2 termelésre legalkalmasabb törzs kiválasztása

5.5.4.4. Az nfap2 genomi jelenlétének bizonyítása az NFAP2 termelő törzs kiválasztásához

5.5.5. Az NFAP2 és peptidfragmenseinek kémiai szintézise. 48

5.5.6. Az rNFAP2, az szNFAP2 és peptid fragmenseinek azonosítása 49

5.5.7. Antifungális érzékenységi tesztek LCM és RPMI 1640 tápoldatban ..........50

5.5.7.1. Minimális gátló koncentráció meghatározása LCM tápoldatban..........50

5.5.7.2. Az rNFAP2 és az FLK MIC értékének meghatározása RPMI 1640 tápoldatban. .51

6. EREDMÉNYEK ÉS ÉRTÉKELÉSÜK...............................................................58

6.1. Az NFAP2 izolálása és azonosítása .............................................................58

6.2. In silico vizsgálatok......................................................................................661

6.3. Az NFAP2 és homológ proteinek filogenetikai analízise ..................................61

6.4. Az NFAP2 antifungális hatásmechanizmusának tanulmányozása ....................65

6.4.1. Antifungális érzékenységi tesztek .............................................................65

6.4.2. Az NFAP2 hatásmechanizmusának mikroszkópos vizsgálata....................66

6.5. Az NFAP2 hőstabilitásának és szerkezetének vizsgálata ................................69

6.6. Az NFAP2 heterológ expressziója ...............................................................71

6.6.1. Az NFAP2 heterológ termelésére alkalmas expressziós vektor létrehozása és bejuttatása a $P$. chrysogenum $\Delta$ paf törzsbe.................................................. 73

6.6.2. Az rNFAP2 termelése, tisztítása és azonosítása ..........................................73

6.7. Az NFAP2 kémiai szintézise .......................................................................76

6.8. A rekombináns és szintetikus NFAP2 antifungális hatásának vizsgálata .........77

6.8.1. A rekombináns és szintetikus NFAP2 MIC értékének meghatározása LCM tápoldatban ...................................................................................................................... 77

6.8.2. Az rNFAP2 MIC értékének meghatározása RPMI 1640 tápoldatban........ 79

6.8.3. Az rNFAP2 és az FLK kölcsönhatásának vizsgálata .................................8 80

6.9. Az NFAP2 funkcionális térképezése ...................................................................83

6.9.1. NFAP2 peptidfragmensek szintézise ....................................................83

6.9.2. Az szNFAP2 peptidfragmensek antifungális hatásámechanizmusának

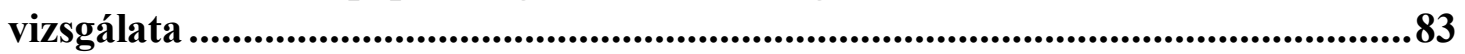

6.10. Az NFAP2 másodlagos és harmadlagos szerkezetének vizsgálata ...................89

6.10.1. A rekombináns és szintetikus NFAP2 RP-HPLC analízise........................89 
6.10.2. A rekombináns és szintetikus NFAP2 szerkezetének vizsgálata ECD spektroszkópiával....................................................................................................90

6.10.3. A rekombináns és szintetikus NFAP2 NMR vizsgálata .............................93

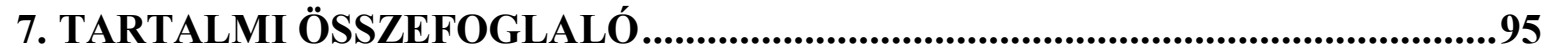

8. ANGOL NYELVÜ ÖSSZEFOGLALÓ (SUMMARY) .......................................101

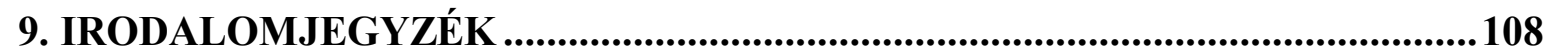

10. KÖSZÖNETNYILVÁNÍTÁS .............................................................................118

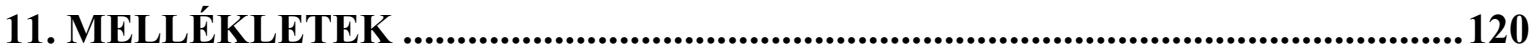




\section{RÖVIDÍTÉSEK JEGYZÉKE}

5-FC: $\quad$ 5-fluorocitozin

ABC: $\quad$ ATP-binding cassette (ATP-kötő kazetta)

AcAFP: $\quad$ Aspergillus clavatus ES1 antifungal protein (A. clavatus ES1 antifungális protein)

AcAMP: Aspergillus clavatus VR1 antimicrobial protein (A. clavatus VR1 antimikrobiális protein)

ACM: $\quad$ Aspergillus nidulans complete medium (A. nidulans komplett tápoldat)

ACN: acetonitril

AFP: Aspergillus giganteus MDH18894 antifungal protein (A. giganteus MDH18894 antifungális protein)

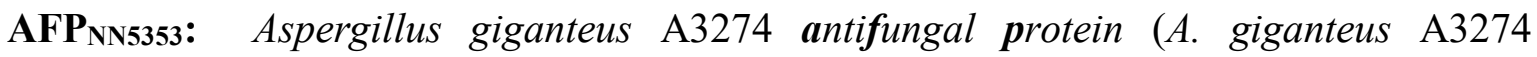
antifungális protein)

AMB: $\quad$ amfotericin B

AnAFP: Aspergillus niger KCTC202 antifungal protein (A. niger KCTC202 antifungális protein)

APS: $\quad$ ammónium-peroxo-diszulfát

ATCC: $\quad$ American Type Culture Collection

BCRC: $\quad$ Bioresource Collection and Research Center, Tajvan

BLAST: Basic Local Alignment Search Tool

BP: $\quad$ Penicillium brevicompactum DierckX bubble protein

cAMP: $\quad$ cyclic adenosine monophosphate (ciklikus adenozin-monofoszfát)

CBS: $\quad$ Centraalbureau voor Schimmelcultures, Utrecht, Hollandia

cDNS: $\quad$ complementary DNS (komplementer DNS)

cgAFP: fonalas tömlősgomba-eredetủ ciszteinben gazdag antifungális protein

CM: $\quad$ Complete medium (komplett táptalaj)

CWI: $\quad$ cell-wall integrity (sejtfalintegritás)

DCC: $\quad N, N$-Dicyclohexylcarbodiimide (N,N-diciklohexil-karbodiimid)

DTT: ditiotreitol

ECD: $\quad$ Electronic circular dichroism (cirkuláris dikroizmus)

EDTA: Ethylenediaminetetraacetic acid (etilén-diamin-tetraecetsav)

ESI-MS: Electrospray ionization mass spectrometry (elektrospray ionizációs tömegspektrométer) 
ExPASy: $\quad$ Expert Protein Analysis System

FGSC: $\quad$ Fungal Genetics Stock Center, Kansas, USA

FICI: fractional inhibitory concentration index (frakcionális gátló koncentráció index)

FITC: fluoreszcein-izotiocianát

FLK: flukonazol

FPAP: $\quad$ Fusarium polyphialidicum SZMC 11042 antifungal protein (F. polyphialidicum antifungális protein

Fr: $\quad$ szintetikus peptidfragmens

GRAVY: grand average of hydropathy value (átlagos hidrofóbicitás érték)

GSH: $\quad$ glutation

GSSG: $\quad$ glutation-diszulfid

HOBt: $\quad$ hydroxybenzotriazole (benzotriazol-1-ol-hidrát)

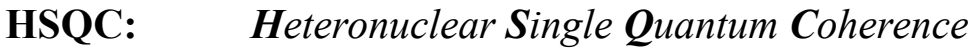

JGI: Joint Genome Institute

KCTC: $\quad$ Korean Collection for Type Cultures, Daejeon, Koreai Köztársaság

Kr-Fr: $\quad$ kevert aminosavsorrendủ szintetikus peptidfragmens

LCM: $\quad$ low cationic medium (alacsony kationtartalmú táptalaj)

MAFP1: Monascus pilosus BCRC 38072 antifungal protein 1 (M. pilosus BCRC 38072 antifungális protein 1)

MDH: $\quad$ Michigan Department of Health, Michigan, USA

MEA: $\quad$ malt extract agar (malátás táptalaj)

MES: $\quad$ 2-N-morfolino-etánszulfonsav

MFS: Major Facilitator Superfamily (fő membrántranszport-elősegítő szupercsalád)

MIC: $\quad$ minimal inhibitor concentration (minimális gátló koncentráció)

MOPS: $\quad$ 4-morfolinpropánszulfonsav

MpkA: $\quad$ mitogén-aktivált protein kináz A

MS: $\quad$ Mass spectrometry (tömegspektrometria)

NAC: $\quad$ non-albicans Candida (nem-albicans Candida)

NAF: $\quad$ Penicillium nalgiovense BFE 66, 67, 474 antifungal protein ( $P$. nalgiovense BFE 66, 67, 474 antifungális protein)

NCBI: $\quad$ National Centre for Biology Information 
NFAP: $\quad$ Neosartorya fischeri NRRL 181 antifungális protein (N. fischeri NRRL 181 antifungális protein)

NFAP2: $\quad$ Neosartorya fischeri NRRL 181 antifungal protein 2 (N. fischeri NRRL 181 antifungális protein 2)

NMR: $\quad$ Nuclear magnetic resonance (mágneses magrezonancia)

NRRL: Northern Regional Research Laboratory, Agricultural Research Service Culture Collection (ARSCC), National Center for Agricultural Utilization Research (NCAUR), Peoria, USA

OB: Oligonucleotide/Oligosaccharide-Binding (oligonukleotid/oligoszacharid kötö)

PAF: Penicillium chrysogenum Q176 antifungal protein (P. chrysogenum Q176 antifungális protein)

Pc-Arctin: Penicillium chrysogenum A096 antifungal protein (P. chrysogenum A096 antifungális protein)

PCMM: Penicillium chrysogenum minimal medium (P. chrysogenum minimál táptalaj)

PCR: $\quad$ polymerase chain reaction (polimeráz láncreakció)

PgAFP: Penicillium chrysogenum RP42C antifungal protein (P. chrysogenum RP42C antifungális protein)

pI: izoelektromos pont

PI: $\quad$ propidium iodide (propídium jodid)

Pka: $\quad$ protein kináz A

Pkc: $\quad$ protein kináz $\mathbf{C}$

Q-TOF: $\quad$ Quadrupole-time of flight (kvadrupól repülési idő)

rNFAP2: rekombináns Neosartorya fischeri antifungális protein 2

ROS: $\quad$ reactive oxigen species (reaktív oxigén gyökök)

RP-HPLC: Reversed-phase high-performance liquid chromatography (fordított fázisú nagy teljesítményü folyadékkromatográfia)

SDS-PAGE: Sodium dodecyl sulfate-polyacrylamide gel electrophoresis (nátrium-laurilszulfát-poliakrilamid gélelektroforézis)

SP: $\quad$ spórapuffer

SZMC: $\quad$ Szeged Microbiology Collection, Szeged, Magyarország

SzNFAP2: $\quad$ szintetikus Neosartorya fischeri antifungális protein 2

TAE: tris-acetate-EDTA (tris-ecetsav-dinátrium-EDTA) 
TE: $\quad$ tris-EDTA

TEMED: tetrametil-etilén-diamin

TFA: $\quad$ trifluoroacetic acid (trifluorecetsav)

TRIS: tris-(hidroximetil)-aminometán

UniProtKB: Universal Protein Knowledgebase

YEGK: $\quad \boldsymbol{y}$ east extract glucose medium (élesztőkivonat-glükóz táptalaj)

YPD: $\quad$ yeast extract-peptone-dextrose medium (élesztőkivonat-pepton-D-glükóz)

A dolgozatban előforduló gének:

afp: $\quad$ Aspergillus giganteus antifungális proteint kódoló gén

ags $A$ : $\quad \alpha$-1,3-glukán-szintázt kódoló gén

CDR1, 2: $\quad$ Candida drog-rezisztencia gén 1, 2

ERG11: lanoszterin-14- $\alpha$-demetilázt kódoló gén

FKS1, 2, 3: 1,3- $\beta$-glukán-szintázt kódoló gén 1, 2, 3

MDR1: $\quad$ multidrog-rezisztencia gén 1

nfap: Neosartorya fischeri antifungális proteint kódoló gén

nfap2: $\quad$ Neosartorya fischeri antifungális proteint 2 kódoló gén

paf: $\quad$ Penicillium chrysogenum antifungális proteint kódoló gén 


\section{BEVEZETÉS}

Az utóbbi néhány évtizedben a gombafertőzések esetszáma folyamatosan emelkedik, ami egyre nagyobb kihívást jelent az egészségügy számára. Jelenleg is a Candida nemzetség tagjai állnak leggyakrabban az invazív gombafertőzések hátterében. Ezek az élesztők általában könnyen kezelhető nyálkahártya canididiázist okoznak immunkompetens egyénekben, azonban a legyengült immunrendszerü páciensekben magas halálozási rátát mutató, szisztémás fertőzést kiválthatnak. A szakirodalom egyre több, a kezelés során alkalmazott antifungális szerekkel (például azolokkal és echinokandinokkal) szemben rezisztens, illetve multirezisztens Candida törzsröl számol be. Mindezek alapján szükségessé vált, a gyógyászatban rutinszerüen alkalmazott, gombaellenes szerek mellett új, alternatív antifungális stratégiák bevezetése.

Az antifungális aktivitással rendelkező természetes eredetű peptidek és proteinek, illetve szintetikus származékaik új, a gombafertőzések kezelésére alkalmazható szerek alapjául szolgálhatnak. Erre a célra, a fonalas tömlősgomba-eredetű ciszteinben gazdag antifungális proteinek (cgAFP) kedvező tulajdonságaik alapján (széles antifungális spektrum, stabilitás extrém környezeti körülmények között, alacsony vagy nem létező toxicitás emlös- és növénysejtekkel szemben) megfelelhetnek. A jelenleg 13 izolált és jellemzett képviselővel rendelkező csoport elsősorban a mezőgazdasági és egészségügyi szempontból fontos patogén fonalasgombákkal szemben mutat növekedésgátló hatást, míg az élesztőgombák ellen csupán néhány esetben írtak le gyenge antifungális aktivitást. Ezek alapján a fehérjecsoport élesztőgombákkal szembeni gyakorlati alkalmazása megkérdőjelezhető.

Munkánk során a Neosartorya fischeri NRRL 181 izolátum fermentlevéből egy új, élesztőellenes aktivitással rendelkező, cgAFP-t izoláltunk. Azonosítását és jellemzését követően megállapítottuk, hogy a protein hatékonyan gátolja számos, klinikai szempontból jelentős Candida izolátum növekedését. Mivel a natív termelő csak kis mennyiségben szekretálja az N. fischeri antifungális protein 2-t (NFAP2), ezért létrehoztunk a fehérje nagy mennyiségben történő termelésére képes Penicillium chrysogenum-alapú heterológ expressziós rendszert, továbbá kémiai módszerrel előállítottuk a fehérje szintetikus változatát, majd összehasonlítottuk a különböző eredetű proteinek szerkezetét, hőstabilitását és hatásmechanizmusát, illetve feltártuk az antifungális aktivitásért felelős fehérjerégiót. 


\section{IRODALMI ÁTTEKINTÉS}

\subsection{A Candida nemzetség klinikai jelentősége}

Az opportunista gombafertőzések esetszáma folyamatosan növekvő tendenciát mutat az utóbbi évtizedekben. Ennek legfőbb okai a fertőzések elsődleges célpontját jelentő immunszupresszált páciensek számának emelkedése és az antibiotikum-rezisztens törzsek mind gyakoribb felbukkanása. A candidiázis az egyik leggyakrabban azonosított szisztémás gombafertőzés a legyengült immunrendszerü betegekben és a nozokomiális fertőzések 8 10\%-áért felelős (Pfaller és Diekema, 2007). A jelenleg több mint 150 fajt magába foglaló Candida nemzetségböl mindössze 15 fajt írtak le humán patogénként (Yapar, 2014). A nemzetség számos tagja széles körben elterjedt a természetben és a normál humán flóra részét képezik. Egészséges gazdaszervezetben a Candida fajok kommenzalista közösséget alkotnak a baktériumokkal és ritkán okoznak súlyos fertőzést. Azonban a gazdaszervezet legyengülését kihasználva (amikor a lokálisan vagy szisztémásan károsodott immunrendszer nem képes kontrollálni a gomba növekedését) a Candida fajok opportunista patogénekként helyi vagy az egész szervezetre kiterjedő fertőzéseket, gyulladásokat alakíthatnak ki, amit összefoglaló néven candidiázisnak nevezünk (Papon és mtsi., 2013).

A Candida fajok felszíni és invazív fertőzéseket egyaránt kiválthatnak. A bőrt, a körmöt, továbbá a száj és genitáliák nyálkahártyáját érintő felszíni fertőzések elsősorban AIDS-ben szenvedő pácienseknél figyelhetők meg, míg a szájpenész és a vaginitisz (hüvelygyulladás) a csecsemők és a felnőtt nők körében gyakoribb (Papon és mtsi., 2013). Az invazív candidiázis (candidémia) magas mortalitási rátát mutat a fiatalok és az idősek körében egyaránt (Pappas és mtsi., 2003; Morgan és mtsi., 2005; Falagas és mtsi., 2010; Pfaller és mtsi., 2010). A véráramba került gomba képes eljutni a legtöbb szervhez és szövethez (szív, szem, központi idegrendszer és csontvelö) és ott megtelepedve gyulladást kiváltani (Pappas, 2006). Számos, a gazdaszervezetre vonatkozó és egészségügyi ellátással kapcsolatos tényező hozzájárulhat az invazív fertőzések kialakulásához. A legfőbb rizikófaktorok közé sorolható a magas életkor, az antibiotikum terápia, a szervtranszplantáció, a katéterhasználat, a sebészeti beavatkozás, a kemoterápia, illetve csecsemők esetében az alacsony születési súly (Pappas, 2006; Bouza és Muñoz, 2008; Playford és mtsi., 2008; Leroy és mtsi., 2009). Mindezeken túl az egyik legnagyobb kockázatot az elhúzódó kórházi tartózkodás jelenti (Pfaller és Diekema, 2007). 
Az összes invazív candidiázis eset 92 - 95\%-ában a következö öt faj azonosítható: $C$. albicans, C. glabrata, C. parapsilosis, C. tropicalis és C. krusei (Pfaller és mtsi., 2010; Lyon és mtsi., 2010; Pfaller és mtsi., 2011; Pfaller és mtsi., 2012; Lockhart és mtsi., 2012). A candidiázisban szenvedő betegekből izolált Candida fajok megoszlási aránya az utóbbi években jelentős változást mutat, azonban még mindig a $C$. albicans felelős a fertőzések döntő hányadáért. Ennek legfőbb okai közé sorolható a flukonazol (FLK) elsődleges terápiás szerként történő alkalmazása és a vénás katéterek egyre elterjedtebb használata a kórházakban (Pappas, 2006; Tortorano és mtsi., 2006; Pfaller és Diekema, 2007; Richardson és Lass-Flörl, 2008; Lass-Flörl, 2009; Rodloff és mtsi., 2011). A FLK napjainkban is az elsődlegesen alkalmazott szer a Candida fajok okozta fertőzések kezelésére azonban széleskörü használata rezisztens törzsek megjelenését eredményezte. Ugyanakkor a FLK még mindig hatékonyan alkalmazható és a fertőzések esetszámának csökkenését eredményezi (Richardson és Lass-Flörl, 2008).

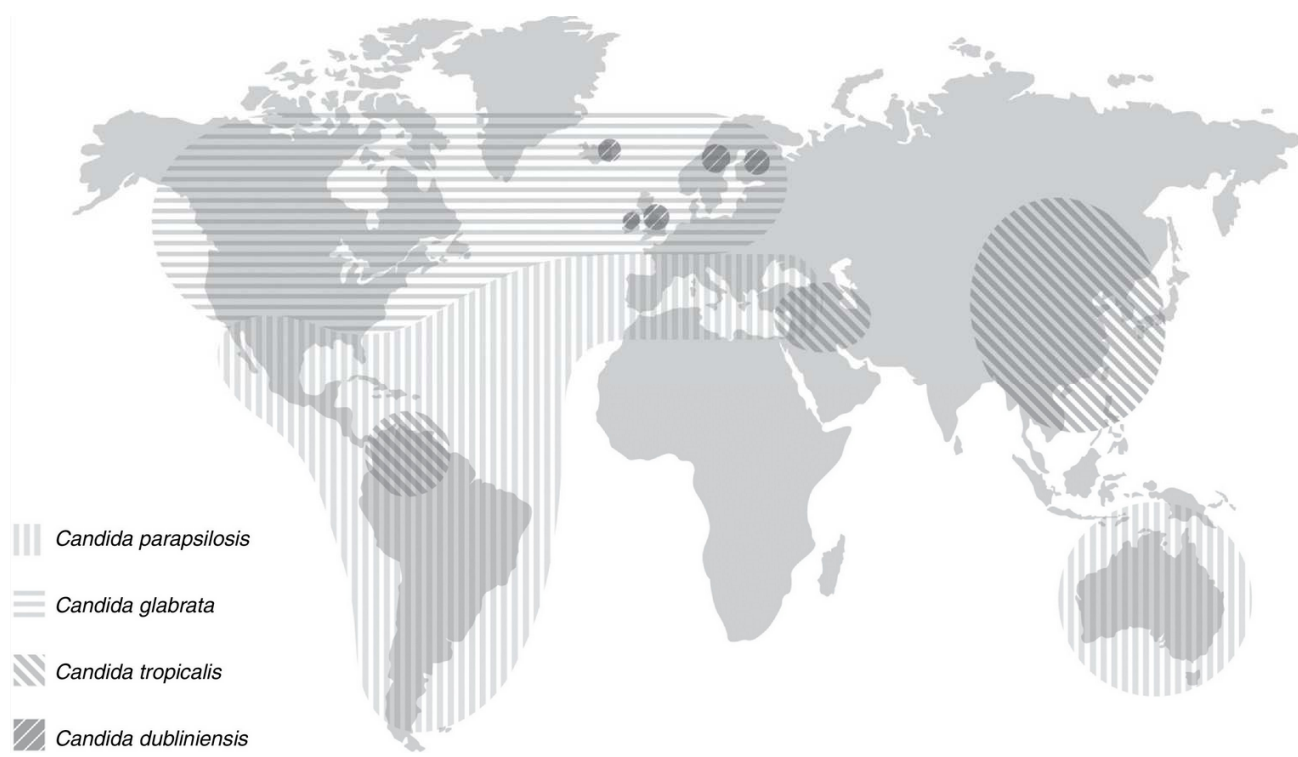

1. ábra. A leggyakrabban előforduló nem-albicans Candida (NAC) fajok elterjedése (Quindós, 2014).

A vénás katéterek használata az újszülöttek körében egyre elterjedtebb, aminek következtében a biofilmképző Candida fajok okozta candidémia mind gyakoribb megjelenése figyelhető meg ebben a korosztályban. Tanulmányok alapján a C. parapsilosis és a C. albicans a két, a katéter használatával összefüggő gombafertőzésekből elsődlegesen 
izolált faj (Pfaller és mtsi., 2002; Puig-Asensio és mtsi., 2014). A nem-albicans Candida (NAC) fajok eloszlási gyakorisága a betegek jellemzői (életkor, nem, betegség), a higiéniás körülmények, a földrajzi elhelyezkedés és az elsődlegesen alkalmazott antifungális szer szerint változik. Candida parapsilosis-t elsősorban újszülöttek és katéterezett páciensek fertőzéseiből izolálnak. Ez a faj háromszor gyakoribb okozója a candidiázisnak ÉszakAmerikában, mint Európában. Ezzel szemben a C. glabrata-t, ami Észak-Amerikában elterjedtebb, mint Latin-Amerikában, elsősorban az idős és daganatos betegekből izoláltak. A C. tropicalis a leukémiás és neutropéniás páciensekben, míg a C. krusei a hematopoetikus össejt transzplantáción átesett és FLK profilaxisban részesülö leukémiás páciensek körében jellemző. Az ázsiai országokban a C. tropicalis okozta esetek száma folyamatosan növekvő tendenciát mutat az utóbbi években (Pappas, 2006; Pfaller és Diekema, 2007; Pfaller és mtsi., 2010).

\subsubsection{A Candida fertőzések kezelése}

\section{A gombafertőzések kezelésére alkalmazott monoterápiás szerek}

Az invazív gombafertőzések kezelése során az azolok, a poliének és az echinokandinok csoportjába tartozó antifungális szereket alkalmazzák (Roemer és Krysan, 2014). Az 1950-es évektől az azolok felfedezéséig leggyakrabban a Streptomyces nemzetség tagjai által termelt természetes poliének osztályába tartozó amfotericin B-t (AMB) alkalmazták a gombafertőzések kezelésére (Wheat és mtsi., 2007; Kuse és mtsi., 2007; Sanglard és mtsi., 2009; Staab és mtsi., 2010; Perfect és mtsi., 2010). Az AMB az ergoszterinhez irreverzibilisen kötődve pórusokat formál a gomba sejtmembránján, ami az ozmotikus egyensúly megváltozásán $\left(\mathrm{Na}^{+}\right.$és $\mathrm{K}^{+}$vesztés) keresztül a sejt halálát okozza (Masia és Gutierrez, 2002; Odds és mtsi., 2003; Sanglard és mtsi., 2009). Az AMB széles spektrumú antifungális szer, alkalmazása ugyanakkor korlátozott, mivel nagy dózisban nefrotoxikus hatású lehet (Bates és mtsi., 2001; Pappas és mtsi., 2009; Wang és mtsi., 2010). A mellékhatások kivédése érdekében kifejlesztett, nagyobb antifungális hatással rendelkező liposzómás és lipid komplex formáit ma már széles körben alkalmazzák az életveszélyes invazív mikózisok kezelésére (Pappas és mtsi., 2009; Perfect és mtsi., 2010). A Candida fajok közül a $C$. lusitaniae, $C$. rugosa, C. glabrata és a $C$. krusei esetében regisztráltak poliénekkel szembeni rezisztenciát (Papon és mtsi., 2013).

Az 1980-as években a gombafertőzések kezelésére bevezetett azolok olyan szintetikus vegyületek, amelyek a lanoszterin-14- $\alpha$-demetiláz müködésében szerepet játszó 
citokróm P450 14a-demetiláz gátlásával megakadályozzák az ergoszterin és ez által a sejtmembrán szintézisét (Shapiro és mtsi., 2011). Ezek a vegyületek szerkezetük alapján lehetnek imidazolok ( 2 nitrogént tartalmaz) vagy triazolok (3 nitrogént tartalmaz). A Candida fajok okozta gombafertőzések kezelése során az általánosan alkalmazott azolok a ketokonazol (imidazol), az FLK és az itrakonazol (első generációs triazolok), illetve a vorikonazol (második generációs triazol). Az imidazolokat általában felületi, míg a triazolokat szisztémás fertőzések kezelésére használják (Ostrosky-Zeichner és mtsi., 2010). Az azolokat alacsony toxicitásuk miatt széles körben alkalmazzák a klinikumban, azonban nagymértékű használatuk összefüggésbe hozható olyan rezisztens Candida törzsek felbukkanásával, melyek eddig érzékenynek bizonyultak velük szemben (Walsh és mtsi., 2008; Perfect és mtsi., 2010; Pappas és mtsi., 2016). A C. albicans esetében megfigyelték, hogy a FLK-rezisztenciát mutató esetek száma nagyon kevés (mindössze 1-3\%) annak ellenére, hogy már több mint 20 éve alkalmazzák a klinikumban (Pfaller és mtsi., 2010; Lyon és mtsi., 2010; Pfaller és mtsi., 2011; Lockhart és mtsi., 2012; Pfaller és mtsi., 2012).

Az echinokandinok a klinikumban használt antifungális szerek legújabb osztálya. A csoport jelenleg elérhető képviselői a kaszpofungin, az anidulafungin és a mikafungin. Ezek a nagyméretü, félszintetikus lipopeptidek a gomba sejtfalának bioszintézisében szerepet játszó 1,3- $\beta$-D-glükán-szintáz gátlásával, a sejtfalintegritás útvonal (cell-wall inegrity, $\mathrm{CWI}$ ) megzavarása révén, a gombasejt halálát okozzák (Denning, 2003). A tápcsatornából alig szívódnak fel, ezért csak intravénásan adhatók a kezelés során. A többi antifungális készítményhez képest az echinokandinok egyáltalán nem vagy csak kis mértékben okoznak mellékhatásokat (Denning, 2003). Ennek ellenére azonban alkalmazási lehetőségük korlátozott, mivel a klinikai szempontból jelentős Candida fajok esetében az echinokandinrezisztencia növekvő tendenciáját figyelték meg (Walker és mtsi., 2010; Arendrup és Perlin, 2014).

\section{A gombafertőzések kezelésére alkalmazott szerkombinációk}

A monoterápiás szerekkel szembeni rezisztencia kialakulásának késleltetése vagy akár megakadályozása érdekében széles körben elterjedt az antifungális szerek kombinációban történő alkalmazása az invazív gombafertőzések kezelésére. A hatékony szerkombinációk képesek a felhasznált vegyületek dózisának, illetve a kezelés időtartamának csökkentésére, továbbá szinergista kölcsönhatás révén javíthatják a szerek antifungális hatékonyságát, nagyobb terápiás hatást és szélesebb aktivitást eredményezhetnek, mint önmagukban (Onyewu és mtsi., 2003; Zimmermann és mtsi., 2007; 
Hill és Cowen, 2015). A legtöbb Candida fajjal szemben az echinokandinok antifungális hatást mutatnak, ennek ellenére még mindig a FLK-t javasolják a fertőzések kezdeti kezelésére (Pappas és mtsi., 2016; McCarty és Pappas, 2016). Az invazív candidiázis esetében a kombinált kezelés nem ajánlott, mivel nem hatékonyabb, mint ha önmagukban alkalmaznánk az antifungális szereket (Pappas és mtsi., 2016).

A Candida fertőzések kezelésére nukleotid analógokat is használnak. Ilyen pl. az 5fluorocitozin (5-FC), a flucitozin szintetikus pirimindinanalógja. Monoterápiás szerként való alkalmazását a vele szembeni rezisztencia gyors kialakulása kizárja, így gyakran AMB-vel kombinálják. Ez a szerkombináció az általános kezelés a $C$. neoformans, a $C$. gattii és más kevésbé gyakori Candida fajok okozta fertőzések esetében (Brown és mtsi., 2012; Day és mtsi., 2013). Az 5-FC a gombasejtbe jutva 5-fluorouracillá metabolizálódik, ami további termékekké alakulva gátolja a protein- és DNS-szintézist (Loyse és mtsi., 2013).

\subsubsection{Azol és echinokandin rezisztencia kialakulása klinikai Candida izolátumokban}

Az utóbbi években a Candida fertőzések ellen széleskörüen alkalmazott triazol és echinokandin terápia rezisztens klinikai izolátumok kialakulását és ezek egyre szélesebb körben történő elterjedését eredményezte.

A triazol-rezisztens fenotípus olyan molekuláris mechanizmusok együttes eredményeként alakulhat ki, mint az alkalmazott antifungális szer intracelluláris koncentrációjának a csökkentése, a lanoszterin-14- $\alpha$-demetiláz termelés növelése és a gomba sejtfal szerkezetének a módosítása (Cowen és mtsi., 2015). A Candida fajok az ATPkötő kazetta $(\mathrm{ABC})$ protein szupercsalád és a fő membrántranszport-elősegítő szupercsalád (MFS) transzportereit használják az antifungális szerek intracelluláris koncentrációjának csökkentésére. Candida albicans klinikai izolátumai esetében megfigyelték, hogy a Candida drog-rezisztencia gén 1 és 2 ( $\mathrm{ABC}$ transzportereket kódoló $C D R 1$ és $C D R 2$ gének), illetve a multidrog-rezisztencia gén 1 (MFS transzportert kódoló MDRl gén) overexpressziója szerepet játszik a rezisztencia kialakulásában, mivel a gének inaktivációja vagy mutációja extrém FLK-érzékeny mutánsokat eredményezett (Sanglard és mtsi., 1997, 2009; Das és mtsi., 2011). Az azolok az ergoszterin-bioszintézis utolsó szakaszában résztvevő enzimek (elsősorban a lanoszterin-14- $\alpha$-demetiláz) gátlásával fejtik ki hatásukat (Das és mtsi., 2011; Snelders és mtsi., 2011; Monk és mtsi., 2014). A lanoszterin-14- $\alpha$-demetilázt kódoló gén (ERG11) mutációi vagy overexpressziója azol-rezisztens fenotípus kialakulását eredményezik Candida izolátumokban. A génben történő mutációk, a lanoszterin-14- $\alpha$ - 
demetiláz szerkezetét megváltoztatva, csökkentik a molekula és a szer közötti kölcsönhatást (Das és mtsi., 2011; Snelders és mtsi., 2011; Monk és mtsi., 2014), míg a gén overexpressziója fokozott ergoszterin bioszintézist eredményez (Cowen és mtsi., 2015). Klinikai C. albicans izolátum esetében megfigyelték, hogy az ERG11 mutációja következtében keresztrezisztencia alakult ki az azolok és az AMB között (Hull és mtsi., 2012).

Nemcsak azol, hanem echinokandin-rezisztens klinikai Candida izolátumokat is leírtak, ami a $C$. albicans, $C$. krusei, és $C$. tropicalis izolátumok esetében ritka, viszont a $C$. glabrata törzsek között egyre gyakoribb (Maubon és mtsi., 2014; Jung és mtsi., 2015). Az

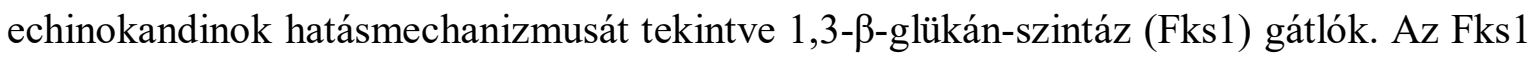
szintéziséért $3 F K S$ gén (FKS1, FKS2, FKS3) felelős (Mazur és mtsi., 1995). Az FKS1 génben végbemenő mutációk eredményezik a rezisztens fenotípus kialakulását, mivel a génben történő átrendeződések következtében megváltozik az Fks1 konformációja, ami által csökken a kölcsönhatás az enzim és a szer között (Balashov és mtsi., 2006; Perlin, 2007; Garcia-Effron és mtsi., 2010; Walker és mtsi., 2010). A másik lehetséges rezisztenciamechanizmus a kitin szintézisének fokozása. C. albicans esetében megfigyelték, hogy a kis mennyiségben jelenlévő echinokandin indukálta a kitin-szintázt kódoló gén expresszióját, aminek következtében megnövekedett a kitin mennyisége a sejtfalban és csökkent a sejtek echinokandinnal szembeni érzékenysége (Walker és mtsi., 2008). Ezt a rezisztenciamechanizmust a $C$. glabrata, C. krusei, $C$. parapsilosis és $C$. tropicalis egyes izolátumainál szintén leírták (Cota és mtsi., 2008; Walker és mtsi., 2013).

Az azol- és echinokandin-rezisztens élesztőgombák megnövekedett száma miatt elengedhetetlenné vált új antifungális szerek és terápiák bevezetése a gyógyászatba. Számos kutatás igazolta, hogy a már alkalmazott antifungális szerek kombinációi ígéretesek lehetnek a gombafertőzések kezelése során, azonban a természetben előforduló antifungális hatású vegyületek, így peptidek és proteinek is, új antifungális terápiák alapjául szolgálhatnak.

\subsection{A fonalas tömlösgombák ciszteinben gazdag antifungális fehérjéi}

Az 1990-es évek második felétől számos cgAFP-t izoláltak és jellemeztek (1. táblázat). A csoportra jellemző legfontosabb tulajdonságok a nagyszámú arginin és lizin jelenléte, ami miatt a fehérje pozitívan töltött, az alacsony molekulatömeg és a 6-8 cisztein által képzett 34 intramolekuláris diszulfid-híddal stabilizált szerkezet. Ez utóbbi tulajdonság nagyfokú stabilitást biztosít a protein számára szélsőséges környezeti körülmények között (pl. magas 
1. táblázat. Az eddig azonosított cgAFP-k fizikai és kémiai tulajdonságai (Virágh, 2015 alapján).

\begin{tabular}{|c|c|c|c|c|c|c|c|c|}
\hline $\begin{array}{c}\text { Antifungális } \\
\text { protein }\end{array}$ & Termelö törzs & $\begin{array}{c}\text { Aminosavak } \\
\text { száma }\end{array}$ & $\begin{array}{c}\text { Molekula- } \\
\text { tömeg (kDa) }\end{array}$ & $\begin{array}{c}\text { Ciszteinek } \\
\text { száma }\end{array}$ & Becsült pI & $\begin{array}{c}\text { Lizinek/argininek } \\
\text { száma }\end{array}$ & Azonosító & Referencia \\
\hline \multicolumn{9}{|c|}{ PAF klasztert hordozó fehérjék } \\
\hline AcAFP & Aspergillus clavatus VR1 & 51 & 5,8 & 8 & 9,06 & $11 / 1$ & ABR10398 & Skouri-Gargouri és mtsi., 2008 \\
\hline AcAMP & Aspergillus clavatus $\mathrm{ES} 1$ & 51 & 5,8 & 8 & 9,06 & $11 / 1$ & ADC55278 & Hajji és mtsi., 2010 \\
\hline AFP & Aspergillus giganteus MDH 18894 & 51 & 5,8 & 8 & 9,27 & $12 / 1$ & X60771 & Wnendt és mtsi., 1994 \\
\hline $\mathbf{A F P}_{\mathrm{NN} 5353}$ & Aspergillus giganteus A3274 & 51 & 5,7 & 8 & 9,30 & $11 / 2$ & n.a. & Binder és mtsi., 2011 \\
\hline AnAFP & Aspergillus niger КСТС 2025 & 58 & 6,6 & 6 & 7,14 & $5 / 3$ & n.a. & Lee és mtsi., 1999 \\
\hline FPAP & Fusarium polyphialidicum SZMC 11042 & 55 & 6,4 & 6 & 9,10 & $12 / 1$ & CAR79015 & Galgóczy és mtsi., 2013a \\
\hline MAFP1 & Monascus pilosus BCRC 38072 & 58 & 6,5 & 6 & 8,3 & $7 / 2$ & AHA86567 & Tu és mtsi., 2016 \\
\hline NAF & Penicillium nalgiovense BFE 66, 67, 474 & 55 & 6,3 & 6 & 8,93 & $13 / 0$ & n.a. & Geisen, 2000 \\
\hline NFAP & Neosartorya fischeri NRRL 181 & 57 & 6,6 & 6 & 8,93 & $11 / 2$ & CAQ42994 & Kovács és mtsi., 2011 \\
\hline PAF & Penicillium chrysogenum Q176 & 55 & 6,3 & 6 & 8,93 & $13 / 0$ & AAA92718 & Marx és mtsi., 1995 \\
\hline \multirow[t]{2}{*}{ PgAFP } & Penicillium chrysogenum $\mathrm{RP} 42 \mathrm{C}$ & 58 & 6,5 & 6 & 8,83 & $8 / 2$ & ACX54052 & Rodriguez-Martin és mtsi., 2010 \\
\hline & \multicolumn{8}{|c|}{ BP klasztert hordozó fehérjék } \\
\hline BP & Penicillium brevicompactum DireckX & 64 & 6,5 & 8 & 7,20 & $4 / 4$ & P83799 & Seibold és mtsi., 2011 \\
\hline Pc-Arctin & Penicillium chrysogenum A096 & 64 & 6,6 & 8 & 7,71 & $2 / 6$ & CAP96194 & Chen és mtsi., 2013 \\
\hline
\end{tabular}

$\mathrm{AFP}_{\mathrm{NN} 5353}$ : A. giganteus A3274 antifungális protein, AnAFP: A. niger KCTC 2025 antifungális protein, BP: Penicillium brevicompactum DierckX bubble protein, FPAP. Fusarium polyphialidicum SZMC 11042 antifungális protein, MAFP1: Monascus pilosus BCRC 38072 antifungális protein 1, NAF: Penicillium nalgiovense BFE 66, 67, 474 antifungális protein, NFAP: Neosartorya fischeri NRRL 181 antifungális protein, PAF: Penicillium chrysogenum Q176 antifungális protein, Pc-Arctin: P. chrysogenum A096 antifungális protein, PgAFP: P. chrysogenum RP42C antifungális protein. MDH: Michigan Department of Health, Michigan, USA; KCTC: Korean Collection for Type Cultures, Daejeon, Koreai Köztársaság; SZMC: Szeged Microbiology Collection, Szeged, Magyarország; BCRC: Bioresource Collection and Research Center, Tajvan, NRRL: Northern Regional Research Laboratory Agricultural Research Service Culture Collection, Peoria, USA; n.a.: nincs adat. 
hőmérséklet, tág pH tartomány), illetve ellenállóvá teszi proteázokkal szemben (Marx, 2004; Meyer, 2008; Galgóczy és mtsi., 2010; Delgado és mtsi., 2015). A fehérjék aminosavszekvenciái nagymértékben eltérnek egymástól, azonban konzervált régiók minden esetben megfigyelhetők, elsősorban a ciszteinek és az őket határoló aminosavak pozíciójában (Marx, 2004; Meyer, 2008; Seibold és mtsi., 2011) (2. ábra).

A hasonló szekvenciamotívumok alapján a cgAFP-ket két nagy csoportba különíthetjük el: a Penicillium chrysogenum antifungális proteinre (PAF) jellemző aminosav klasztert és a Penicillium brevicompactum „,bubble protein”-re (BP) jellemző aminosav klasztert tartalmazó proteinek csoportjába (Seibold és mtsi., 2011) (2. ábra). A két csoportba tartozó fehérjék közös tulajdonsága, hogy hatékony antifungális aktivitással rendelkeznek (Marx, 2004; Meyer, 2008; Seibold és mtsi., 2011). Míg a PAF-klaszterrel rendelkező proteinek elsősorban fonalasgombákkal (Marx, 2004; Meyer, 2008; Galgóczy, 2010), addig a BP-klaszterrel rendelkező proteinek az élesztő- és fonalasgombákkal szemben egyaránt mutatnak növekedésgátló hatást (Seibold és mtsi., 2011; Chen és mtsi., 2013).

A cgAFP-k biológiai szerepéről kevés információ áll a rendelkezésünkre. Meyer és Stahl (2003) az Aspergillus giganteus és a Fusarium oxysporum együtt-tenyésztése során az A. giganteus által termelt, a Fusarium fajok növekedését gátló antifungális proteint (AFP) kódoló afp gén fokozott transzkripcióját figyelték meg. Az AFP-re nem érzékeny élesztőgombákkal (Saccharomyces cerevisiae, C. albicans) és baktériummal (Pseudomonas aeruginosa) történő együtt-tenyésztés hasonló transzkripciószint változást eredményezett a gén esetében (Meyer és Stahl, 2003). Mindezek alapján arra következtettek, hogy az AFP fokozott expressziójáért felelős transzkripciós faktorok a megváltozott $\mathrm{pH}, \mathrm{a}$ tápanyagkorlátozás és a különböző eredetű külső stressz folyamatok következtében aktiválódnak, amiket egy másik mikroorganizmus jelenléte válthat ki a gomba környezetében. Mindezt alátámasztja az a megfigyelés, hogy az afp gén 5'-upstream régiója a külső környezeti szignálokra és stresszhatásra termelődő, a transzkripciót szabályozó elemek kötőhelyeit tartalmazza (Marx, 2004; Meyer, 2008). Az AFP esetében megfigyelt eredmények alapján arra a megállapításra jutottak, hogy a cgAFP-k fontos szerepet játszanak a tápanyagokért és az élőhelyért folytatott versenyben a hasonló ökológiai niche-t elfoglaló mikroorganizmusokkal szemben, és ez nagymértékben függ a kompetítor fajok fiziológiai állapotától. Ezt a megfigyelést támasztják alá az AFP-rokon Neosartory fischeri antifungális protein (NFAP)-termelő és NFAP-deléciós mutáns $N$. fischeri NRRL 181 törzsekkel végzett in vitro antagonizmus tesztek eredményei is (Kovács, 2014). 


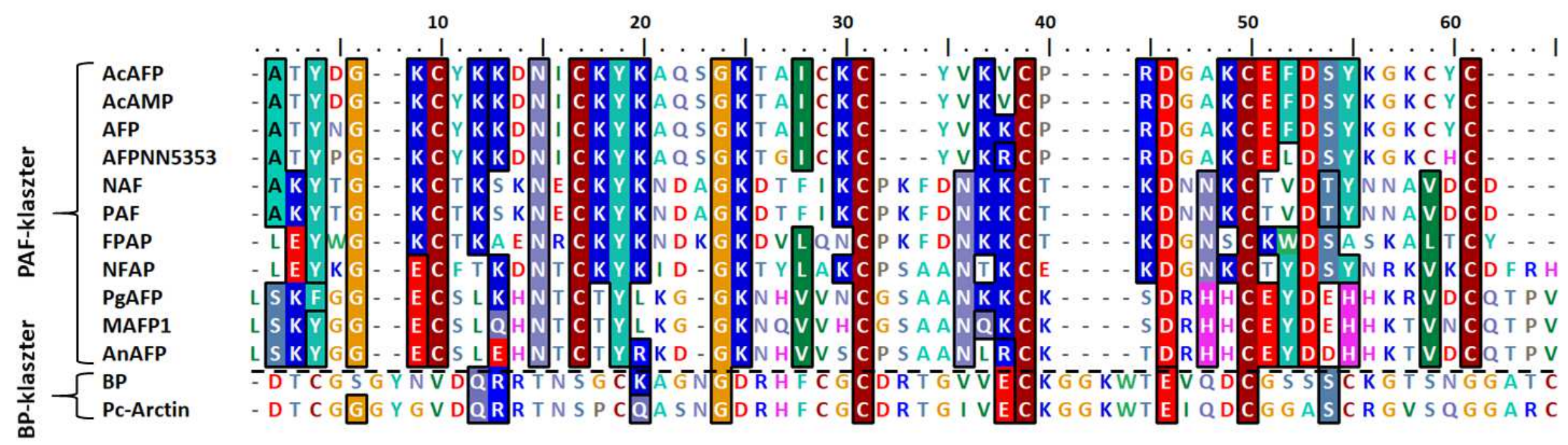

2. ábra. Az eddig izolált cgAFP-k aminosav-szekvenciáinak illesztése. AcAFP: Aspergillus clavatus VR1 antifungális ptotein (azonosító: ABR1039), AcAMP: A. clavatus ES1 antimikrobiális protein (azonosító: ABR10398), AFP: Aspergillus giganteus MDH 18894 antifungális protein (azonosító: X60771), AFPNN5353: A. giganteus A3274 antifungális protein, AnAFP: A. niger KCTC 2025 antifungális protein, BP: Penicillium brevicompactum DierckX bubble protein (azonosító: P83799), FPAP: Fusarium polyphialidicum SZMC 11042 antifungális protein (azonosító: CAR79015), MAFP1: Monascus pilosus BCRC 38072 antifungális protein 1 (azonosító: AHA86567), NAF: Penicillium nalgiovense BFE 66, 67, 474 antifungális protein, NFAP: Neosartorya fischeri NRRL 181 antifungális protein (azonosító: CAQ42994), PAF: Penicillium chrysogenum Q176 antifungális protein (azonosító AAA92718), Pc-Arctin: P. chrysogenum A096 antifungális protein (azonosító: CAP96194), PgAFP: P. chrysogenum RP42C antifungális protein (azonosító: ACX54052). MDH: Michigan Department of Health, Michigan, USA; KCTC: Korean Collection for Type Cultures, Daejeon, Koreai Köztársaság; SZMC: Szeged Microbiology Collection, Szeged, Magyarország; BCRC: Bioresource Collection and Research Center, Tajvan, NRRL: Northern Regional Research Laboratory Agricultural Research Service Culture Collection, Peoria, USA. 


\subsubsection{A cgAFP-k szerkezete, a szerkezet és hatásmechanizmus összefüggése}

A cgAFP-k aminosav-szekvenciái 9-96\% hasonlóságot mutatnak egymással, azonban konzervált homológ régiók minden esetben megfigyelhetők a ciszteinek és a velük szomszédos aminosavak pozícióiban (2. ábra). A PAF-klaszter csoport tagjainak elsődleges szekvenciái 25-96\% hasonlóságot mutatnak, míg ez a BP-klaszter csoport tagjainál 80\%. Az Aspergillus clavatus ES1 antifungális protein (AcAFP) és az A. clavatus VR1 antimikrobiális protein (AcAMP), illetve a PAF és a Penicillium nalgiovense BFE 66, 67, 474 antifungális protein (NAF) aminosav-szekvenciája egymással teljesen megegyezik (Geisen, 2000; Marx, 2004; Meyer, 2008; Skouri-Gargouri és mtsi., 2008; Hajji és mtsi., 2010).

A cgAFP-k preproproteinként szintetizálódnak. Az éretlen proteinek az N-terminális végen tartalmaznak egy szignál szekréciós szekvenciát és azt követően egy proszekvenciát, amit egy KexB-szerű proteáz hasít le az érett proteinről (Wnendt és mtsi., 1990, 1994; Martínez-Ruiz és mtsi., 1997). A PAF-ra érzékeny Aspergillus nidulans törzsekben termeltetett, csak proszekvenciát tartalmazó és preproszekvencia nélküli PAF formák vizsgálata során bebizonyították, hogy a szignálszekvencia a protein szekréciójáért felelős, míg a proszekvencia, mint egy „intramolekuláris chaperon”, a még kitekeredett fehérjéhez kötődve megakadályozza a protein szekréció előtti aktiválódását, ezáltal megvédi a termelő szervezetet a fehérje antifungális hatásától, továbbá megakadályozhatja a fehérje sejten belüli lebomlását is (Eder és Fersht, 1995; Marx és mtsi., 2005). Az érett fehérjék 51-64 aminosav hosszú, 5,8-6,6 kDa tömegü, 6-8 ciszteint tartalmazó molekulák (1. táblázat).

A fonalas tömlősgomba-eredetű ciszteinben gazdag fehérjék harmadlagos szerkezete nagymértékű hasonlóságot mutat egymással (3. ábra). Kísérletesen ez idáig csak az AFP (Campos-Olivas és mtsi., 1995), a PAF (Batta és mtsi., 2009) és a BP (Olsen és mtsi., 2004) szerkezetét határozták meg mágneses magrezonancia spektroszkópia (NMR) (AFP és PAF esetében) és röntgenkrisztallográfia (BP esetében) segítségével. Továbbá néhány protein harmadlagos szerkezetét in silico homológia modellezéssel tárták fel (Skouri-Gargouri és mtsi., 2009; Kovács és mtsi., 2011; Seibold és mtsi., 2011; Galgóczy és mtsi., 2013a, 2017; Tu és mtsi., 2016).

Az AFP 5 antiparallel $\beta$-redőjét három rövid hurokrégió köti össze, amelyek két, egymással merőleges szöget bezáró $\beta$-lemezt létrehozva egy $\beta$-hordó stuktúrát alakítanak ki (Campos-Olivas és mtsi., 1995; Olsen és mtsi., 2004; Meyer, 2008; Batta és mtsi., 2009). Az AFP egy központi hidrofób maggal rendelkezik, amit poláros és aromás aminosavak vesznek körül. Az aminosavak felületi eloszlása a fehérje nagymértékü oldékonyságát eredményezi 

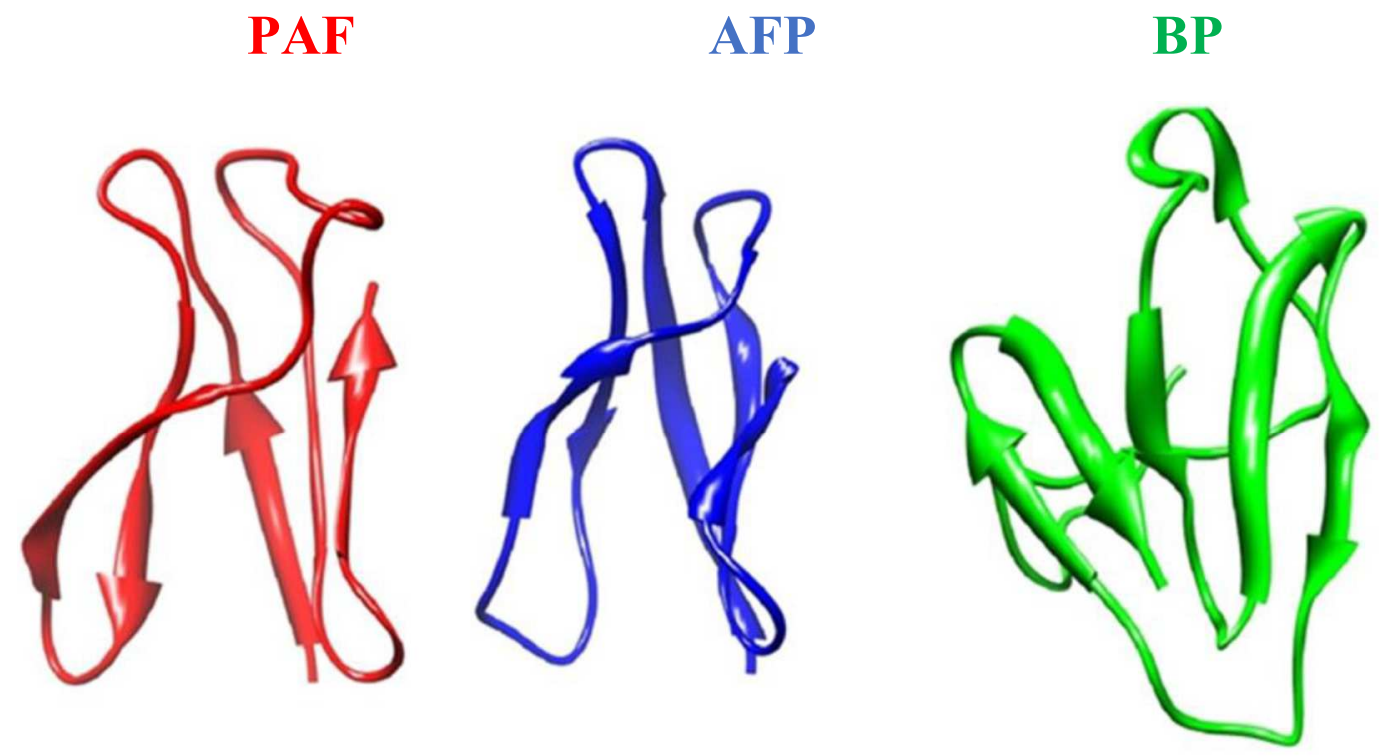

3. ábra. A Penicillium chrysogenum Q176 antifungális protein (PAF; NMR, Protein Data Bank (PDB) azonosító: 2KCN), az Aspergillus giganteus MDH 18894 antifungális protein (AFP; NMR, PDB azonosító: 1AFP) és a Penicillium brevicompactum DierckX "bubble protein" (BP, röntgen krisztallográfia, PDB azonosító: 1UOY) harmadlagos térszerkezeti képe (Seibold és mtsi., 2011).

különböző oldószerekben (Campos-Olivas és mtsi., 1995). Az AFP harmadlagos szerkezetét a 7., 14., 26., 28., 33., 40., 49. és 51. pozíciókban elhelyezkedő ciszteinek között kialakuló diszulfid-hidak stabilizálják, melyek a kialakult cisztein párok alapján „abcdabcd” mintázatba rendeződnek (a cisztein párok a 7-33., 14-40., 26-49. és 28-51. pozíciójú aminosavpárok között jönnek létre). A 9., 10. és 32. pozícióban jelenlévő lizinek által kialakított pozitív felszíni régók és a szomszédságukban elhelyezkedő hidrofób árok (29. és 45. tirozin, 30. és 50. valin) következtében az AFP egy amfipatikus struktúrát vesz fel (Campos-Olivas és mtsi., 1995). Az AFP rendelkezik egy oligonukleotid/oligoszacharidkötő (OB) doménnel is, ami a protein RNS-hez, DNS-hez, oligoszacharidokhoz és proteinekhez történő kötődését teszi lehetővé (Meyer, 2008). In vitro kísérletek bizonyították, hogy az AFP az OB motívumán keresztül a DNS-hez kötődve kromatinkondenzációt okoz (del Pozo és mtsi., 2002). Továbbá az N-terminális végén elhelyezkedő kitin-kötő doménjén keresztül képes a gombasejtfal felépítésében szerepet játszó kitinhez kapcsolódni, így a sejtfal kiépülését megakadályozni (Meyer, 2008).

A PAF harmadlagos szerkezete az AFP-hez hasonlóan 3 hurokrégióval összekapcsolt 5 antiparallel lefutású $\beta$-redőből áll. Az $5 \beta$-redő $2 \beta$-lemezt hoz létre, ami egy $\beta$-hordó struktúrát alakít ki. A 7., 14., 28, 36., 43. és az 54. pozícióban lévő 6 cisztein által alkotott 3 diszulfid-híd, a két $\beta$-lemezt körbevéve, egy rejtett, központi hidrofób magot hoz létre (Batta 
és mtsi., 2009). A ciszteinek által kialakított diszulfid-hidak, a kialakult cisztein párok alapján, „abcabc” mintázatba rendeződnek (a cisztein párok a 7-36., 14-43. és 28-54. pozíciójú aminosavpárok között jönnek létre) (Batta és mtsi., 2009; Váradi és mtsi., 2013). A PAF szintén egy pozitív és negatív töltésű felületi régiókat tartalmazó amfipatikus molekula (Batta és mtsi., 2009). A pozitív töltésü régiókat a 9., 35. és 38. pozícióban lévő lizin aminosavak alkotják (Batta és mtsi., 2009). A diszulfid-hidak és a pozitívan töltött lizingazdag régiók fontos szerepet játszanak a protein megfelelö, antifungálisan aktív szerkezetének kialakításában. Kísérletesen bizonyították, hogy a diszulfid-hidak ditiotreitollal (DTT) történő redukciója után a PAF antifungális aktivitása csökken Aspergillus niger-rel szemben, illetve a pozitív töltésü régiók mutációja szintén szignifikáns csökkenést eredményez a protein növekedésgátló hatásában (Batta és mtsi., 2009). Az AFPvel ellentétben a PAF nem rendelkezik OB-kötő doménnel, így nem képes sem nukleinsavhoz sem kitinhez kötődni in vitro (Marx és mtsi., 2007; Batta és mtsi., 2009).

A BP-klasztert hordozó proteinek elsődleges-szekvenciája nagymértékben különbözik a PAF-klasztert hordozó proteinekétöl (2. ábra). Ennek ellenére a BP harmadlagos szerkezete nagymértékü hasonlóságot mutat az AFP és a PAF harmadlagos szerkezetével (3. ábra). A protein az N-terminális végén egy 26 aminosavból álló hurokrégióval rendelkezik, amit egy 3 antiparallel $\beta$-redő által kialakított $\beta$-lemez követ. A molekula a C-terminális végén 2 antiparallel $\beta$-redö által kialakított $\beta$-lemezt tartalmaz. A 2 $\beta$-lemez $\beta$-hordó-szerü struktúrát alakít ki. A protein szerkezetét 4 , a 8 cisztein által alkotott diszulfid-híd stabilizálja, ugyanazzal a topológiával (,abcdabcd”), mint amit az AFP esetében is megfigyeltek. Két diszulfid-híd az N-terminális hurokrégiót és az első $\beta$-lemezt, míg a másik kettő a két $\beta$-lemezt kapcsolja össze (Olsen és mtsi., 2004). Az AFP-től és a PAF-tól eltérően, a BP esetében a $2 \beta$-lemez a molekula N-terminális végén található 26 aminosavból álló hurokrégióval együtt egy tölcsért képez. Az aminosavak a molekula egyik végén kis, negatív töltésű, a másik végén pedig nagy, pozitív töltésű felületi régiót alakítanak ki, aminek következtében a molekula bipoláris jelleget kap (Olsen és mtsi., 2004).

A PAF-klasztert hordozó AcAFP, Fusarium polyphialidicum SZMC 11042 antifungális protein (FPAP), Monascus pilosus BCRC 38072 antifungális protein 1 (MAFP1), NFAP és $P$. chrysogenum RP42C antifungális protein (PgAFP) szintén $\beta$-hordó szerkezettel rendelkezik az in silico szerkezetvizsgálatok alapján. Harmadlagos szerkezetüket 3, a 6 cisztein által alkotott diszulfid-híd stabilizálja a PAF-éhoz hasonló szerkezeti mintázattal, kivételt az AcAFP képez, ahol a 8 cisztein 4 diszulfid-hidat alakít ki 
„abcdabcd” mintázatban (Skouri-Gargouri és mtsi., 2009; Kovács és mtsi., 2011; Seibold és mtsi., 2011; Galgóczy és mtsi., 2013a; Tu és mtsi., 2016).

\subsubsection{A cgAFP-k hatásmechanizmusa}

A cgAFP-k hasonló fenotipikus változásokat eredményeznek a velük szemben érzékeny fonalasgombákban (gátolt vagy késleltetett spóracsírázás; többszörösen elágazó, duzzadt végü hifafonalak létrejötte), azonban a hatásmechanizmusuk eltérő lehet. Mind ez idáig csak néhány protein esetében végeztek részletes vizsgálatot az antifungális hatás hátterében végbemenő folyamatok megismerésére. A három legintenzívebben tanulmányozott protein, az AFP, a PAF és az NFAP, hasonló szerkezetük, funkciójuk és antifungális spektrumuk ellenére különböző módon fejtik ki hatásukat.

Az AFP hatásmechanizmusának vizsgálata során megfigyelték, hogy az alkalmazott AFP kisebb hányada, pozitívan töltött felülete révén, képes a vele szemben érzékeny gombasejtek membránjának negatívan töltött foszfolipideihez kötődni, azon pórusokat képezni, ezáltal a plazmamembrán permeabilitását megváltoztatni (Theis és mtsi., 2003). Az AFP nagyobb hányada ugyanakkor a sejtfal külső rétegében és a sejtfalban felhalmozódva, valószínűsíthetően a kitinhez kötődve megzavarja a sejtfal megfelelő kiépülését (Theis és mtsi., 2005; Hagen és mtsi., 2007). Ezzel szemben az AFP-rezisztens gombasejtekben a protein intracellulárisan, a vakuólumokban halmozódik fel, majd a normál degradatív folyamatok során lebomlik (Theis és mtsi., 2003, 2005). Az AFP-vel szemben érzékeny $A$. niger, Aspergillus oryzae és F. oxysporum fajokkal végzett in vivo kísérletek bebizonyították, hogy az AFP gátolja a kitin-szintázok müködését és ezáltal megakadályozza a sejtfal megfelelő kiépülését. A III-as típusú kitin-szintáz A. oryzae mutáns, illetve az V-ös típusú kitin-szintáz A. oryzae és $F$. oxysporum mutánsok vizsgálata során a deléciós mutánsok kisebb mértékü érzékenységet mutattak AFP-kezeléssel szemben a vad típusú törzsekhez képest. Továbbá megfigyelték, hogy a III-as és V-ös típusú kitinszintáz kizárólag az AFP-érzékeny fonalasgombákban fordul elő (Hagen és mtsi., 2007). A kitinszintézis során a kitin-szintázok specifikus mikrovezikulákban (kitoszómákban) transzportálódnak a hifacsúcsokhoz (Ruiz-Herrera és Martinez-Espinoza, 1999). A kitinszintázok a plazmamembránhoz transzportálódva felszabadulnak a vezikulákból és proteolitikus aktivációjukat követően az $\mathrm{N}$-acetil-glükózamin polimerizációjában vesznek részt. A kitin molekulák a plazmamembrán mentén mikrofibrillumokat alakítanak ki és a sejtfal más komponenseihez kapcsolódnak (Ruiz-Herrera és Martinez-Espinoza, 1999; 
Cohen, 2001). Mivel számos folyamat áll a kitinszintézis hátterében, több lehetséges magyarázat is létezik az AFP kitinszintézist gátló aktivitására: a fehérje (1) zavarhatja a kitoszómák plazmamembránhoz történő transzportját, (2) megakadályozhatja a kitinszintázok felszabadulását a kitoszómákból, (3) illetve a kitin-szintázok plazmamebránhoz történő lehorgonyzását, (4) gátolhatja a kitin-szintázok aktivitását, (5) továbbá zavarhatja a kitin mikrofibrillumok sejtfalba épülését (Meyer, 2008). Érzékeny gombákban az AFP, a sejtfal bioszintézis közvetett vagy közvetlen módon történő megakadályozásával, zavarja a hifák polarizált növekedését, aminek következtében az érzékeny törzsekben a protein kináz C A/mitogén-aktivált proteinkináz A (PkcA/MpkA) szignalizációs útvonalon keresztül indukálódik a CWI-útvonal (Theis és mtsi., 2003; Li és mtsi., 2006). Az AFP gombaellenes aktivitásában feltételezhetően az OB-kötő doménje is fontos szerepet játszik, mivel így képes kölcsönhatásba lépni nukleinsavakkal és oligoszacharidokkal (del Pozo és mtsi., 2002).

$\mathrm{AFP}_{\mathrm{NN5353}}$-mal kezelt $A$. nidulans-ban megfigyelték, hogy a PkcA/MpkA útvonal szabályozza a proteinnel szembeni sejtválaszt. Továbbá bebizonyították, hogy a fehérje hatására megemelkedik az $\alpha$-1,3-glükán-szintáz gén $\left(a_{S S A}\right)$ transzkripciója $A$. niger-ben, ami a sejtfal újraépítését indukálja (Binder és mtsi., 2011). A PkcA/MpkA útvonal mellett a $\mathrm{Ca}^{2+}$ szignalizációs kaszkádnak is fontos szerepe van az $\mathrm{AFP}_{\mathrm{NN} 5353}$ aktivitásában. A fehérje hatására A. niger-ben megemelkedik az intracelluláris $\mathrm{Ca}^{2+}$ koncentrációja (Binder és mtsi., 2011), ami a $\mathrm{Ca}^{2+}$-homeosztázis hirtelen megváltozása révén programozott sejthalált indukál

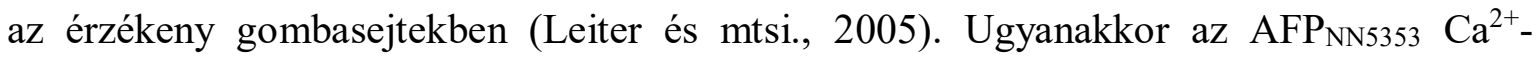
szignalizációs kaszkádon keresztül, a ChsD kitin szintáz expressziójának indukciója révén, a sejtfal újraépítését indukálja (Binder és mtsi., 2011). Az egy- és kétértékü kationok antifungális aktivitásra gyakorolt neutralizáló hatását az $\mathrm{AFP}_{\mathrm{NN} 5353}$ esetében bizonyították (Binder és mtsi., 2011).

A PAF az AFP-hez hasonlóan több szinten fejti ki antifungális hatását. A protein receptormediált endocitózissal jut be a sejtbe és ott a citoplazmában lokalizálódik (Kaiserer és mtsi., 2003; Leiter és mtsi., 2005; Marx és mtsi., 2008). A PAF a vele szemben érzékeny gombasejtekben a plazmamembrán hiperpolarizációját eredményezi, továbbá intracelluláris reaktív oxigén gyökök (ROS) képződését és apoptózist indukál (Kaiserer és mtsi., 2003; Leiter és mtsi., 2005; Marx és mtsi., 2005). Antifungális hatását részben a FadA-SfaD-GpgA ( $\alpha$-, $\beta$ - és $\gamma$-alegységek) -függő heterotrimer G-protein kapcsolt jelátviteli útvonalon keresztül fejti ki (Marx és mtsi., 2008). Aspergillus nidulans fadA ${ }^{G 203 R}$ gén vizsgálata során megerösítették a PAF G-protein kapcsolt aktivitását (Leiter és mtsi., 2005). Az A. nidulans 
fadA $A^{G 203 R}$ mutánsban a heterotrimer G-protein FadA alegységének 203. pozíciójában jelenlévő glicin argininra történő cseréje miatt az $\alpha$-alegység nem tud disszociálni a $\beta \gamma$ alegységről (Leiter és mtsi., 2005). Ez a mutáns a PAF-fal szemben kevésbé volt érzékeny, mint a vad típus, ami arra enged következtetni, hogy aktív heterotrimer G-protein szükséges a protein megfelelő antifungális aktivitásához (Leiter és mtsi., 2005; Marx és mtsi., 2008). PAF kezelést követően az érzékeny gombák hifáinak végénél a plazmamembrán azonnali hiperpolarizációja és jelentős mértékű $\mathrm{K}^{+}$kiáramlás figyelhető meg, ami az intracelluláris ionhomeosztázis felborulásához vezet (Marx és mtsi., 2008). A PAF, receptormediált endocitózisát követően, a citoplazmatikus ROS képződés indukálása révén, programozott sejthalált eredményez (Kaiserer és mtsi., 2003; Leiter és mtsi., 2005; Marx és mtsi., 2005). PAF-fal szemben érzékeny $A$. nidulans-ban megállapították, hogy a protein indukálja a heterotrimer G-protein kapcsolt jelátviteli útvonal által aktivált ciklikus adenozinmonofoszfát/protein kináz A (cAMP/PkaA) szignalizációs kaszkádot, ami az aktin abnormális polimerizációját, a polarizált növekedés zavarát és apoptózist eredményez (Binder és mtsi., 2010). Az AFP ${ }_{\mathrm{NN} 5353}-\mathrm{hoz}$ hasonlóan PAF esetében is megfigyelték a citoplazmatikus $\mathrm{Ca}^{2+}$ koncentráció megemelkedését a proteinnel kezelt Neurospora crassaban, ami a $\mathrm{Ca}^{2+}$-homeosztázis felborulása révén programozott sejthalált vált ki (Binder és mtsi., 2010).

Az NFAP hatásmechanizmusa elsősorban a PAF esetében leírtakkal mutat nagymértékü hasonlóságot. Az NFAP mikroszkópos vizsgálatai során azt tapasztalták, hogy a fehérjével történő rövid idejü kezelést követően csökken a vele szemben érzékeny $A$. nidulans metabolikus aktivitása és apoptózist indukál, továbbá csökkenti a sejtek falának kitintartalmát és a hifák szubapikális régiójában való lokalizációját eredményezi (Virágh és mtsi., 2015). Megfigyelték, hogy a fehérje közvetlen módon hatást gyakorol a növekvő hifa apikális régiójának aktinmintázatára, így annak kitineloszlására is, ami a polarizált növekedés megzavarását okozza az érzékeny gombafajokban (Virágh és mtsi., 2015). A PAF és az $\mathrm{AFP}_{\mathrm{NN} 5353}$ aktív receptormediált endocitózisával ellentétben az NFAP valószínűsíthetően passzív diffúzióval jut a sejtbe. Aspergillus nidulans mutánsok vizsgálata során leírták, hogy az NFAP heterotrimer G-protein-kapcsolt receptorhoz kötődve a cAMP/PkaA szignalizációs útvonal aktiválása révén apoptózist indukál és gátolja a poláris hifanövekedést. Az NFAP a PAF-hoz (Binder és mtsi., 2010) hasonlóan, de az AFP-vel ellentétben (Binder és mtsi., 2011) nem indukálja a CWI-t, hanem egy MpkA által aktivált, a CWI-útvonaltól független célponton keresztül apoptotikus folyamatot hoz létre (Virágh és mtsi., 2015). A cgAFP-k eddig azonosított hatásmechanizmusát a 2. táblázat foglalja össze. 
Az élesztőgombákkal szemben hatékonynak bizonyuló cgAFP-k (mint pl. a BP) antifungális hatásának mechanizmusát mind ez idáig nem vizsgálták.

\section{2. táblázat. A cgAFP-k hatásmechanizmusa.}

\begin{tabular}{|c|c|c|}
\hline Protein & Hatásmechanizmus & Referencia \\
\hline AFP & Plazmamembrán permeabilizáció és kitin szintézis gátlás & $\begin{array}{l}\text { Theis és mtsi., 2003; Hagen } \\
\text { és mtsi., } 2007\end{array}$ \\
\hline $\mathbf{A F P}_{\mathrm{NN5353}}$ & $\begin{array}{l}\mathrm{Ca}^{2+} \text {-beáramlás, az intracelluláris } \mathrm{Ca}^{2+} \text {-homeosztázis megzavarása, MAPK } \\
\text { szignalizáció és sejtfal integritás útvonal aktiválás }\end{array}$ & Binder és mtsi., 2011 \\
\hline PAF & $\begin{array}{l}\text { Plazmamembrán hiperpolarizáció, } \mathrm{K}^{+} \text {kiáramlás és } \mathrm{Ca}^{2+} \text { beáramlás, az } \\
\text { intracelluláris } \mathrm{Ca}^{2+} \text {-homeosztázis megzavarása, cAMP/PKA szignalizáció, } \\
\text { intracelluláris ROS képződés és apoptózis indukció }\end{array}$ & $\begin{array}{l}\text { Leiter és mtsi., 2005; Binder } \\
\text { és mtsi., 2010; Kaiserer és } \\
\text { mtsi., } 2003\end{array}$ \\
\hline NFAP & cAMP/PKA és Pkc/Mpk szignalizáció aktiválása és apoptózis indukció & Virágh és mtsi., 2015 \\
\hline
\end{tabular}

AFP: Aspergillus giganteus $\mathrm{MDH} 18894$ antifungális protein, $\mathrm{AFP}_{\mathrm{NN} 5353}$ : A. giganteus $\mathrm{A} 3274$ antifungális protein, NFAP: Neosartorya fischeri NRRL 181 antifungális protein, PAF: Penicillium chrysogenum Q176 antifungális protein, MDH: Michigan Department of Health, Michigan, USA; NRRL: Northern Regional Research Laboratory Agricultural Research Service Culture Collection, Peoria, USA.

\subsubsection{A cgAFP-k antifungális spektruma}

A cgAFP-k eltérő aminosav-szekvenciájuk ellenére nagyon hasonló fenotípusváltozást eredményeznek a rájuk érzékeny gombákban (Marx, 2004). A fonalasgombák hifáinak növekedésének gátlásával többszörösen elágazó hifák, duzzadt hifavégek megjelenését eredményezik, továbbá gátolják a spórák csírázását is (Kaiserer és mtsi., 2003; Marx, 2004; Theis és mtsi., 2003, 2005).

A cgAFP-k által kiváltott hatás dózisfüggő. Szubletális koncentrációtartományban csak lassítják a gomba növekedését, azonban magasabb koncentrációban már fungicid hatást fejtenek ki (Theis és mtsi., 2003; Kaiserer és mtsi., 2003; Marx, 2004). Hatásukat az egy- és kétértékü kationok jelenléte jelentős mértékben csökkenti. Kaiserer és mtsi. (2003) megfigyelték, hogy a $20 \mathrm{mM}$-nál nagyobb koncentrációjú $\mathrm{MgCl}_{2}$ és az $50-100 \mathrm{mM}$ koncentrációjú $\mathrm{Na}_{2} \mathrm{SO}_{4}$ szignifikánsan csökkenti a PAF antifungális hatását. Az AFP esetében is bebizonyították, hogy a $20 \mathrm{mM}$-nál nagyobb koncentrációjú $\mathrm{KH}_{2} \mathrm{PO}_{4}$ illetve az 50-100 mM koncentrációjú $\mathrm{KCl} / \mathrm{NaCl}$ jelenlétében csökken a fehérje antifungális hatékonysága (Theis és mtsi., 2003). Hasonló hatást írtak le az AcAFP és az NFAP esetében is (Skouri-Gargouri és mtsi., 2009, Galgóczy és mtsi., 2013a). A fonalas tömlősgombák antifungális fehérjéihez hasonlóan a növényi és bakteriális eredetű antimikrobiális proteinek hatékonysága is csökken egy- és kétértékü kationok jelenlétében, amit azzal magyaráznak, 
hogy kompetíció által megakadályozzák a pozitív töltésü proteinek kötődését a célorganizmus negatívan töltött membránjához (Cociancich és mtsi., 1993; Abad és mtsi., 1996; Hughes és mtsi., 2000; Lee és mtsi., 2002).

Korábbi tanulmányok alapján a cgAFP-k fajspecifikusak és antifungális spektrumuk, kismértékü átfedéssel, nagyon eltérö lehet (Marx, 2004). Növekedésgátló hatással rendelkeznek mezőgazdasági és egészségügyi szempontból fontos patogén fonalasgombák ellen (Lacadena és mtsi., 1995; Lee és mtsi., 1999; Geisen, 2000; Theis és mtsi., 2003; Kaiserer és mtsi., 2003; Marx, 2004; Moreno és mtsi., 2003, 2006; Galgóczy és mtsi., 2005, 2007, 2008; Meyer, 2008; Barna és mtsi., 2008; Kovács és mtsi., 2011; Virágh és mtsi., 2014). A járomspórás gombákkal szemben csak a PAF és az FPAP mutatott hatékony aktivitást (Galgóczy és mtsi., 2010, 2013a). A bazídiumos gombák érzékenységéről jelenleg kevés információ áll rendelkezésünkre. Az AFP-vel szemben a Rhodotorula mucilaginosa rezisztensnek, az AnAFP-vel és a PAF-fal szemben a Trichosporon beigelii és a Puccinia recondita f. sp. tritici érzékenynek bizonyult (Lacadena és mtsi., 1995; Lee és mtsi., 1999; Barna, 2008). Meglepő módon az eddig izolált cgAFP-k közül csak egy esetében írtak le baktériumellenes hatást. Az A. clavatus által termelt AcAMP hatékony növekedésgátló aktivitást mutatott Staphylococcus aureus, Bacillus cereus, Micrococcus luteus, Enterococcus faecalis, P. aeruginosa és Escherichia coli ellen (Hajji és mtsi., 2010). Néhány viszonylag magas koncentrációban alkalmazott fehérje esetében élesztőkkel szemben kiváltott növekedésgátló hatást is megfigyeltek. A PAF-klaszterrel rendelkező proteinek közül az AnAFP és az FPAP; a BP-klaszterrel rendelkezők közül pedig csak a BP mutatott gyenge élesztőellenes aktivitást a Candida nemzetségbe tartozó fajokkal és a $S$. cerevisiaevel szemben (Lee és mtsi., 1999; Seibold és mtsi., 2011; Galgóczy és mtsi, 2013a).

Az eddig izolált cgAFP-k antifungális spektrumát a 3. táblázat tartalmazza.

\subsubsection{A cgAFP-k alkalmazási lehetőségei}

A világszerte megjelenő gombafertőzések komoly gondot jelentenek mind az egészségügy, mind a mezőgazdaság számára. A gyógyászatban a legfőbb problémát a jelenleg alkalmazott szerekkel szemben rezisztenssé váló patogén gombák számának folyamatos emelkedése jelenti. A gombafertőzések kezelésére az antifungális szerek 3 csoportját (azolok, echinokandinok és poliének) alkalmazzák leggyakrabban, azonban ezek alkalmazási lehetősége is korlátozott. Ennek legfőbb oka a gyakran alacsony gombaellenes 
3. táblázat. Az eddig izolált cgAFP-k gombaellenes spektruma (Virágh, 2015 alapján).

\begin{tabular}{|c|c|c|}
\hline Protein & Érzékeny mikroorganizmus & Referencia \\
\hline \multicolumn{3}{|c|}{ PAF-klaszter } \\
\hline AcAFP & $\begin{array}{l}\text { Ascomycota: Alternaria solani, Aspergillus niger, Botrytis cinerea, Fusarium spp. } \\
\text { (Fusarium oxysporum, Fusarium solani), Stachybotrys microspora, Trichoderma reesei }\end{array}$ & $\begin{array}{l}\text { Skoura Gargouri és } \\
\text { Gargouri } 2008\end{array}$ \\
\hline AcAMP & $\begin{array}{l}\text { Ascomycota: } \text { A. niger, F. oxysporum, F. solani } \\
\text { Gram+ baktériumok: Bacillus cereus, Enterococcus faecalis, Escherichia coli, } \\
\text { Klebsiella pneumoniae, Micrococcus luteus, Pseudomonas aeruginosa }\end{array}$ & Hajji és mtsi., 2010 \\
\hline AnAFP & $\begin{array}{l}\text { Ascomycota: Aspergillus spp. (A. flavus, A. fumigatus), Candida albicans, Fusarium } \\
\text { spp. (F. oxysporum, F. solani), Saccharomyces cerevisiae } \\
\text { Basidiomycota: Trichosporon beigelii }\end{array}$ & Lee és mtsi., 1999 \\
\hline AFP & $\begin{array}{l}\text { Ascomycota: Alternaria alternata, Aspergillus spp. (A. flavus, A. nidulans, A. niger, A. } \\
\text { terreus, A. welwitschiae), Botrytis cinerea, Erysiphe graminis, Fusarium spp. (F. } \\
\text { aqueductum, F. bubigenum, F. culmorum, F. equiseti, F. lactis, F. lini, F. moniliforme, } \\
\text { F. oxysporum, F. poae, F. proliferatum, F. sambucinum, F. solani, F. sporotrichioides, } \\
\text { F. vasinfectum), Gliocladium roseum, Magnaporthe grisea, Penicillium purpurogenum, } \\
\text { Trichoderma spp. (T. harzianum, T. koningii) } \\
\text { Oomycota: Phytophthora infestans }\end{array}$ & $\begin{array}{l}\text { Lacadena és mtsi., } 1995 \\
\text { Moreno és mtsi., 2003, } \\
2006 \\
\text { Theis és mtsi., } 2003 \\
\text { Meyer } 2008\end{array}$ \\
\hline $\mathbf{A F P}_{\mathrm{NN5353}}$ & $\begin{array}{l}\text { Ascomycota: Aspergillus spp. (A. flavus, A. fumigatus, A. giganteus, A. nidulans, } A . \\
\text { niger, A. terreus), Botrytis cinerea, Fusarium spp. (F. oxysporum f. sp. oxysporum, } F \text {. } \\
\text { sambucinum), Gliocladium roseum, Neurospora crassa, P. chrysogenum, T. koningii }\end{array}$ & Binder és mtsi., 2011 \\
\hline FPAP & $\begin{array}{l}\text { Ascomycota: Aspergillus spp. (A. nidulans, A. niger, A. terreus), Candida spp. }(C \text {. } \\
\text { inconspicua, C. lusitaniae, C. norvegica), Cladosporium herbarum, T. harzianum } \\
\text { Zygomycota: Gilbertella persicaria }\end{array}$ & Galgóczy és mtsi., 2013a \\
\hline MAFP1 & $\begin{array}{l}\text { Ascomycota: } \text { Acremonium persicinum, Colletotrichum truncatum, Fusarium spp. }(F . \\
\text { proliferatum, F. oxysporum), Helminthosporium spp. (H. cucumerinum, H. panici, H. } \\
\text { seasamum, H. torulosum), Paecilomyces formosus, Pestalotia psidii, Scopulariopsis } \\
\text { brevicaulis }\end{array}$ & Tu és mtsi., 2016 \\
\hline NAF & $\begin{array}{l}\text { Ascomycota: Aspergillus flavus; Byssochlamys sp.; Fusarium solani; Geotrichum } \\
\text { candidum; Penicillium spp. (P. digitatum; P. italicum; P. roquefortii) } \\
\text { Zygomycota: } \text { Mucor } \mathrm{sp.}\end{array}$ & Geisen 2000 \\
\hline NFAP & $\begin{array}{l}\text { Ascomycota: Aspergillus spp. (A. nidulans, } \text { A. niger) } \\
\text { Zygomycota: Rhizomucor miehei }\end{array}$ & Kovács és mtsi., 2011 \\
\hline PgAFP & 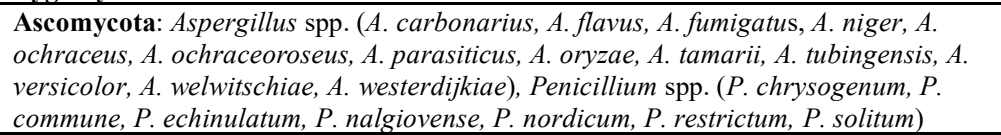 & $\begin{array}{l}\text { Rodriguez-Martin és } \\
\text { mtsi., } 2010 \\
\text { Delgado és mtsi., } 2015\end{array}$ \\
\hline PAF & $\begin{array}{l}\text { Ascomycota: Aspergillus spp. (A. flavus, A. fumigatus, A. giganteus, A. nidulans, } A \text {. } \\
\text { niger, A. terreus), Blumeria graminis f. sp. hordei, Botrytis cinerea, Cladosporium } \\
\text { herbarum, Cochliobolus carbonum, F. oxysporum, Gliocladium roseum, Hypocrea } \\
\text { orientalis, } N \text {. crassa, Microsporum canis, M. gypseum, Trichoderma spp. (T. atroviride, } \\
\text { T. harzianum, T. inhamatum, T. koningii, T. longibrachiatum, Trichophyton spp. (T. } \\
\text { mentagrophytes, T. rubrum, T. tonsurans) } \\
\text { Basidiomycota: Puccinia recondita } \mathrm{f} \text {. sp. tritici } \\
\text { Zygomycota: Lichtheimia corymbifera, Micromucor ramanniana, Mortierella spp. (M. } \\
\text { elongata, M. natalensis, M. wolfii), Mucor piriformis, Mycotypha africana, Rhizomucor } \\
\text { miehei, Rh. pusillus, Rhizopus microsporus var. oligosporus, } R \text {. oryzae, Thamnostylum } \\
\text { piriforme, Umbellopsis isabellina, Zygorrhynchus macrocarpus }\end{array}$ & $\begin{array}{l}\text { Kaiserer és mtsi., } 2003 \\
\text { Marx } 2004 \\
\text { Galgóczy és mtsi., 2005, } \\
2007,2008 \\
\text { Barna és mtsi., } 2008\end{array}$ \\
\hline \multicolumn{3}{|c|}{ BP-klaszter } \\
\hline BP & Ascomycota: $S$. cerevisiae & Seibold és mtsi., 2011 \\
\hline Pc-Arctin & Ascomycota: Paecilomyces variotii, Alternaria longipes, Trichoderma viride & Chen és mtsi., 2013 \\
\hline
\end{tabular}

AcAMP: Aspergillus clavatus VR1 antimikrobiális protein, AcAFP: A. clavatus ES1 antifungális protein, AFP: Aspergillus giganteus $\mathrm{MDH} 18894$ antifungális protein, AFP ${ }_{\mathrm{NN} 5353}$ : A. giganteus $\mathrm{A} 3274$ antifungális protein, AnAFP: Aspergillus niger KCTC 2025 antifungális protein, FPAP: Fusarium polyphialidicum SZMC 11042 antifungális protein, MAFP1: Monascus pilosus BCRC38072 antifungális protein 1, NAF: Penicillium nalgiovense BFE 66, 67, 474 antifungális protein, NFAP: Neosartorya fischeri NRRL 181 antifungális protein, PAF: Penicillium chrysogenum Q176 antifungális protein, PgAFP: P. chrysogenum RP42C antifungális protein, BP: Penicillium brevicompactum Dierck X „bubble protein”, Pc-Arctin: $P$. chrysogenum A096 antifungális protein. MDH: Michigan Department of Health, Michigan, USA; KCTC: Korean Collection for Type Cultures, Daejeon, Koreai Köztársaság; SZMC: Szeged Microbiology Collection, Szeged, Magyarország; BCRC: Bioresource Collection and Research Center, Tajvan, NRRL: Northern Regional Research Laboratory Agricultural Research Service Culture Collection, Peoria, USA. 
hatékonyság, ami inkább fungisztatikus mint fungicid, illetve az azolok és poliének nagy dózisú alkalmazása esetén kialakuló súlyos, szervkárosító mellékhatások (Gupte és mtsi., 2002; Hector, 2005). A mezőgazdaságban a fonalasgombák által okozott, világszerte hatalmas terméskiesést ('́gy nemzetgazdasági veszteséget is) eredményező gombás fertőzések leküzdése jelenti a legnagyobb problémát (Talbot, 2003; Edwards, 2004). Mindezek alapján, új, biztonságosan alkalmazható, alacsony költséggel előállítható, hatékony antifungális szerek kifejlesztése vált szükségessé.

A cgAFP-k tulajdonságaik alapján megfelelnek a gyógyászati- és növényvédőszerekkel szemben támasztott legfontosabb követelményeknek (Meyer és Stahl, 2003; Marx, 2004; Galgóczy és mtsi., 2005, 2007, 2008; Meyer, 2008). Hatékonyan gátolják a mezőgazdasági és egészségügyi szempontból fontos patogén fonalasgombák növekedését (Lacadena és mtsi., 1995; Lee és mtsi., 1999; Geisen, 2000; Theis és mtsi., 2003; Kaiserer és mtsi., 2003; Marx, 2004; Moreno és mtsi., 2003, 2006; Galgóczy és mtsi., 2005, 2007, 2008; Meyer, 2008; Barna és mtsi., 2008; Kovács és mtsi., 2011; Virágh és mtsi., 2015). Diszulfid-hidakkal stabilizált szerkezetüknek köszönhetően jelentős stabilitást mutatnak magas hőmérsékleten és szélsőséges pH-értékeken, továbbá ellenállóak proteázokkal szemben (Marx, 2004; Meyer, 2008; Galgóczy és mtsi., 2010; Delgado és mtsi., 2015).

Gyakorlati alkalmazhatóságukat már több kísérlettel is igazolták. Az AFP és a PAF esetében is bizonyították, hogy nem toxikusak emlős sejtekre in vitro, nem indukálnak proinflammatorikus (gyulladáskeltő) citokin termelődést és nem módosítják az emlős neuronok, asztrociták és vázizomrostok ioncsatornáinak müködését gombanövekedést gátló koncentrációtartományban (Szappanos és mtsi., 2005, 2006). A PAF in vivo kísérletekben sem indukált citokintermelődést és nem okozott szervkárosodást egér tüdőaszpergillózis modellben (Palicz és mtsi., 2013). Mindezek mellett a PAF esetében igazolták, hogy in vitro szinergista kölcsönhatást mutat AMB-vel, sztatinokkal és FLK-val (Galgóczy és mtsi., 2007, 2008; Palicz és mtsi., 2016). Ezzel összhangban tüdőaszpergillózisos egérmodellben a PAF és az AMB együttes alkalmazása megnövelte a fertőzött egerek túlélési idejét (Palicz és mtsi., 2016). Az AFP mezőgazdaságban történő alkalmazásának lehetőségeit már több növényvédelmi kísérletben is megvizsgálták. Vila és mtsi. (2001) a protein közvetlenül a rizsnövény felületén történő alkalmazásával védelmet biztosítottak Magnaporthe grisea okozta fertőzéssel szemben, míg Theis és mtsi. (2005) a paradicsom gyökerének AFP-vel történő előkezelésével a növény $F$. oxysporum fertőzéssel szembeni megnövekedett ellenállóképességét tapasztalták. Az említett vizsgálatok során az AFP-kezelés nem 
károsította a növényt, az normális növekedést és morfológiát mutatott, továbbá a fertilitását is megörizte (Meyer, 2008).

Midezek alapján a cgAFP-k ígéretes jelöltjei lehetnek új, a gyógyászatban és a növényvédelemben egyaránt alkalmazható gombaellenes szereknek.

\subsubsection{A cgAFP-k heterológ expressziója}

A cgAFP-k extracelluláris szekréciójuknak köszönhetően könnyen tisztíthatók a termelő fonalasgomba fermentlevéből. Az AFP és PAF esetében megfigyelték, hogy a fehérjehozam a maximumot a leoltást követően 70-90. órával, a gomba stacionárius növekedési fázisában éri el. A termelés hatékonyságát a különböző környezeti faktorok és vegyületek befolyásolhatják (Marx és mtsi., 1995; Meyer és mtsi., 2002; Marx, 2004). Így például a lúgos pH, a só, az alkohol, a magas hőmérséklet, a szén- és foszfátéhezés, továbbá más gombával történő együtt-tenyésztés fokozza az afp gén transzkripcióját, míg a savas $\mathrm{pH}$ és a feleslegben adott foszfát jelenléte gátolja azt (Meyer és mtsi., 2002; Marx, 2004; Meyer, 2008). Azonban a termelö gomba még a termelés szempontjából figyelembe vehető stresszkörülmények alkalmazása ellenére is viszonylag kis mennyiségben választja ki a fehérjét a környezetébe (López-García és mtsi., 2010; Tu és mtsi., 2016), így a fehérjék ilyen módon történő, nagy mennyiségben való előállítása és tisztítása idő- és költségigényes lehet.

Az antimikrobiális proteinek előállítása szempontjából a leghatékonyabb módszer a heterológ expressziós rendszerben történő termeltetés, amit már néhány cgAFP (AFP, PAF, NFAP és MAFP1) esetében hatékonyan alkalmaztak (Marx és mtsi., 2005; Batta és mtsi., 2009; López-García és mtsi., 2010; Galgóczy és mtsi., 2013b; Virágh és mtsi., 2014; Tu és mtsi., 2016; Sonderegger és mtsi., 2016). Az AFP, PAF és NFAP heterológ termeltetésére Pichia pastoris- (Marx és mtsi., 2005; Batta és mtsi., 2009; López-García és mtsi., 2010; Galgóczy és mtsi., 2013b; Virágh és mtsi., 2014), a MAFP1 esetében pedig E. coli-alapú expressziós rendszert használtak (Tu és mtsi., 2016). Ezek az expressziós rendszerek ugyanakkor számos hátrányos tulajdonsággal rendelkeznek. Az antifungális proteinek termeltetésére alkalmazott heterológ expressziós rendszerekkel szemben elvárt legfontosabb követelmény a fehérje megfelelő feltekeredése a megfelelő diszulfid-híd mintázattal, ami elengedhetetlen a funkcionálisan aktív fehérje szempontjából (Batta és mtsi., 2009). Az E. coli-alapú expressziós rendszerrel történő termeltetés egyszerü és költséghatékony, továbbá magas fehérjehozamot biztosít (Demain és Vaishnav, 2009), ugyanakkor a termelés során gyakran előfordul a fehérje endotoxinnal történő szennyeződése, helytelen feltekeredése és 
a diszulfid-kötések kialakulásának hiánya vagy annak nem megfelelő mintázata, valamint az alacsony oldhatósága (Demain és Vaishnav, 2009; Rosano és Ceccarelli, 2014). A P. pastoris élesztőgomba egy megbízhatóbb expressziós rendszer, amely a megfelelő szerkezet kialakításával aktív protein termelésére alkalmas lehet (Demain és Vaishnav, 2009). Azonban ez a gomba nem kívánt fehérje-módosításokat (O-kapcsolt és nem kovalensen kapcsolt cukrok) és magas koncentrációjú mannán szekréciót eredményez a tápközegbe (Palczewska és mtsi., 2003). Mindezek miatt fonalasgombákat is alkalmaznak homológ és heterológ gének kifejeztetésére (Nevalainen és mtsi., 2005; Su és mtsi., 2012). A $P$. chrysogenum hatékonyan alkalmazható expressziós rendszer (Graessle és mtsi., 1997; Díez és mtsi., 1999), amelyet már a PAF, PAF-mutánsok (aminosav-szekvencia módosított mutánsok) és az NFAP heterológ módon történő termelésére is sikeresen alkalmaztak (Sonderegger és mtsi., 2016). A termeltetés során az erősen kifejeződő paf gén promóterét, a megfelelő fehérjefeldolgozáshoz és szekrécióhoz szükséges paf preproszekvenciát és a paf gén terminációs szignált tartalmazó expressziós kazettát használtak (Marx és mtsi., 1995; Sonderegger és mtsi., 2016). A transzformáns $P$. chrysogenum törzsek minimál tápoldatban való tenyésztése a fehérjék fermentléből történő, egyszerü, egylépéses kromatográfiás tisztítását tette lehetővé (Sonderegger és mtsi., 2016). Ezek alapján a $P$. chrysogenum-alapú heterológ expressziós rendszer hatékonyan alkalmazható lehet más, nem csak a PAF-klaszter csoportba tartozó, cgAFP-k nagymennyiségü termeltetésére is. 


\section{CÉLKITŰZÉSEK}

Az utóbbi három évtizedben, a Candida fajok által kiváltott megbetegedések száma ugrásszerűen megemelkedett ugyanis a fertőzések kezelése során alkalmazott antifungális szerek gyakran nem megfelelö hatékonyságúak, szük spektrumúak és káros mellékhatásaik lehetnek a gazdaszervezetre, továbbá rezisztens klinikai izolátumok kialakulását és ezek egyre gyakoribb megjelenését eredményezhetik. Mindezek alapján új, biztonságosan alkalmazható, alacsony költséggel elöállítható, hatékony antifungális szerek kifejlesztése vált szükségessé. Ennek a kihívásnak eleget tehetnek a cgAFP-k.

Korábbi, előzetes kísérleteinkben megfigyeltük, hogy a minimál tápoldatban tenyésztett $N$. fischeri NRRL 181 fermentleve és annak fehérjetartalma gátolja az élesztőgombák növekedését. Doktori munkám témájául az élesztőellenes antifungális hatás hátterében álló protein azonosítását és jellemzését választottuk, amit $N$. fischeri antifungális protein 2-nek (NFAP2) neveztünk el. Az NFAP2 tanulmányozása tovább bővítheti a cgAFPkről már meglévő ismereteinket és a Candida fajok okozta fertőzések kezelésére hatékonyan alkalmazható, új terápiás stratégiák kifejlesztését teheti lehetővé.

Mindezek alapján a következő konkrét célokat fogalmaztuk meg:

1. Az NFAP2 izolálása és azonosítása a $N$. fischeri NRRL 181 fermentlevéből. A protein tisztítása, azonosítása és fizikai, kémiai tulajdonságainak meghatározása in silico módszerekkel.

2. Az NFAP2 filogenetikai kapcsolatainak feltárása. NFAP2 homológok adatbázisokban történő keresése, továbbá a protein és más cgAFP-k evolúciós kapcsolatának vizsgálata.

3. Az NFAP2 hatékonyságának és hatásmechanizmusának tanulmányozása. A protein növekedésgátló hatásának vizsgálata in vitro klinikai szempontból is jelentős élesztő- és fonalasgomba izolátumokkal szemben. A fehérje élesztősejtekre gyakorolt hatásának megfigyelése mikroszkópos módszerekkel.

4. Az NFAP2 hőstabilitásának és szerkezetének vizsgálata. A fehérje antifungális aktivitásának vizsgálata hővel történő kezelést követően in vitro és az NFAP2 másodlagos szerkezetének tanulmányozása cirkuláris dikroizmus (ECD) spektroszkópia segítségével. 


\section{Az NFAP2 nagy mennyiségben történő előállítása $P$. chrysogenum-alapú heterológ}

expressziós rendszerben. Az NFAP2-t kódoló cDNS expressziós vektorba történő klónozása, a $P$. chrysogenum $\Delta p a f$ törzs vektorral történő transzformációja, majd a rekombináns NFAP2 (rNFAP2) termeltetése, tisztítása és azonosítása.

6. Az NFAP2 kémiai szintézise. A szintetikus NFAP2 (szNFAP2) szilárd fázisú peptidszintézissel és natív kémiai ligációval történő előállítása és tisztítása fordított fázisú nagy teljesítményü folyadékkromatográfia (RP-HPLC) segítségével. Továbbá a szintetikus protein azonosítása.

7. Az rNAFP2 és szNFAP2 antifungális hatásának vizsgálata. A $P$. chrysogenum által termelt és a kémiai módszerekkel szintetizált NFAP2 antifungális hatásának vizsgálata klinikai szempontból jelentős Candida fajokkal szemben in vitro, és aktivitásuk összehasonlítása a natív NFAP2-vel. Az rNFAP2 antifungális hatásának vizsgálata FLK-val kombinációban alkalmazva.

8. Az NFAP2 funkcionális térképezése. A kémia szintézissel előállított NFAP2 peptidfragmensek élesztősejtekre gyakorolt hatásának vizsgálata in vitro illetve mikroszkóp használatával.

9. Az NFAP2 másodlagos és harmadlagos szerkezetének előzetes vizsgálata. A szerkezet meghatározása RP-HPLC, ECD spektroszkópia és NMR segítségével. 


\section{ANYAGOK, ESZKÖZÖK ÉS MÓDSZEREK}

\subsection{A kísérletek során alkalmazott mikroorganizmusok}

A munkánk során vizsgált mikroorganizmusokat a 4. táblázat foglalja össze.

4. táblázat. A dolgozatban vizsgált mikroorganizmusok jegyzéke.

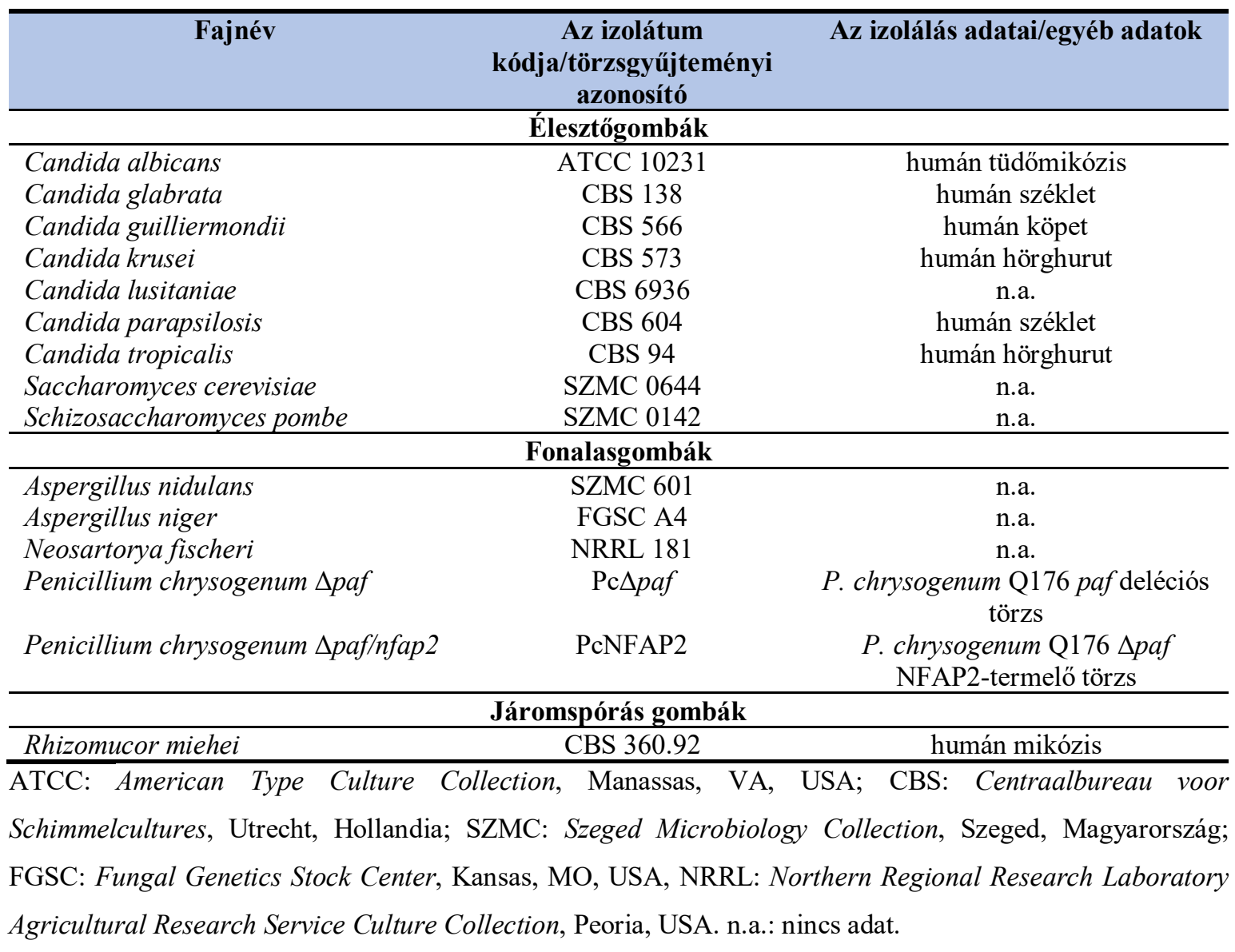

\subsection{Alkalmazott tápközegek és tenyésztési körülmények}

\subsubsection{Tápközegek}

Alacsony kationtartalmú tápoldat/táptalaj (low cationic medium, LCM): 0,5\% (m/V\%) D-glükóz, 0,025\% (m/V\%) élesztőkivonat, 0,0125\% (m/V\%) pepton, táptalaj készítése esetén $2 \%(\mathrm{~m} / \mathrm{V} \%)$ agar. 
Aspergillus (nidulans) komplett tápoldat (Aspergillus (nidulans) complete medium, ACM): $2 \%(\mathrm{~m} / \mathrm{V} \%)$ D-glükóz, $0,2 \%(\mathrm{~m} / \mathrm{V} \%)$ pepton, $0,1 \%(\mathrm{~m} / \mathrm{V} \%)$ élesztőkivonat, $0,1 \%$ (m/V\%) NZ-amin (Sigma-Aldrich), 2\% (V/V\%) sóoldat*, 0,1\% (V/V\%) nyomelemoldat (pH 6,5)**. *Sóoldat: 2,6\% (m/V\%) KCl, 2,6\% (m/V\%) $\mathrm{MgSO}_{4} \times 7 \mathrm{H}_{2} \mathrm{O}, 7,6 \%(\mathrm{~m} / \mathrm{V} \%)$ $\mathrm{KH}_{2} \mathrm{PO}_{4}, 0,2 \%$ (V/V\%) kloroform, **Nyomelemoldat (pH 6,5): 0,1\% (m/V\%) $\mathrm{FeSO}_{4} \times 7$ $\mathrm{H}_{2} \mathrm{O}, \quad 0,9 \% \quad(\mathrm{~m} / \mathrm{V} \%) \quad \mathrm{ZnSO}_{4} \times 7 \quad \mathrm{H}_{2} \mathrm{O}, \quad 0,4 \% \quad(\mathrm{~m} / \mathrm{V} \%) \quad \mathrm{CuSO}_{4} \times 5 \quad \mathrm{H}_{2} \mathrm{O}, 0,01 \% \quad(\mathrm{~m} / \mathrm{V} \%)$ $\mathrm{MnSO}_{4} \times \mathrm{H}_{2} \mathrm{O}, 0,01 \%(\mathrm{~m} / \mathrm{V} \%) \mathrm{H}_{3} \mathrm{BO}_{3}, 0,01 \%(\mathrm{~m} / \mathrm{V} \%) \mathrm{Na}_{2} \mathrm{MoO}_{4} \times 2 \mathrm{H}_{2} \mathrm{O}$.

Élesztőkivonat-glükóz táptalaj (yeast extract-glucose medium, YEGK): 1\% (m/V\%) Dglükóz; $1 \%(\mathrm{~m} / \mathrm{V} \%) \mathrm{KH}_{2} \mathrm{PO}_{4} ; 0,5 \%(\mathrm{~m} / \mathrm{V} \%)$ élesztőkivonat, $2 \%(\mathrm{~m} / \mathrm{V} \%)$ agar.

Élesztőkivonat-pepton-glükóz tápoldat/táptalaj (yeast extract-peptone-glucose medium, YPD): $1 \%(\mathrm{~m} / \mathrm{V} \%)$ élesztőkivonat, $2 \%(\mathrm{~m} / \mathrm{V} \%)$ pepton, $2 \%(\mathrm{~m} / \mathrm{V} \%)$ D-glükóz, táptalaj készítése esetén $2 \%(\mathrm{~m} / \mathrm{V} \%)$ agar.

Komplett táptalaj (complete medium, CM): 5\% (V/V\%) sóoldat*, 0,1\% (V/V\%) vitaminoldat** (V/V\%), 1\% (m/V\%) D-glükóz, 0,085\% (m/V\%) $\mathrm{NaNO}_{3}, 0,15 \%(\mathrm{~m} / \mathrm{V} \%)$ kazaminosav, 0,2\% (m/V\%) pepton, $0,1 \%(\mathrm{~m} / \mathrm{V} \%)$ élesztőkivonat. *Sóoldat: $2,6 \%(\mathrm{~m} / \mathrm{V} \%)$ $\mathrm{KCl}, 2,6 \%(\mathrm{~m} / \mathrm{V} \%) \mathrm{MgSO}_{4} \times 7 \mathrm{H}_{2} \mathrm{O}, 7,6 \%(\mathrm{~m} / \mathrm{V} \%) \mathrm{KH}_{2} \mathrm{PO}_{4}, 5 \%(\mathrm{~V} / \mathrm{V} \%)$ nyomelemoldat, Nyomelemoldat: 0,004\% (m/V\%) Na-borát, 0,04\% (m/V\%) $\mathrm{CuSO}_{4} \times 5 \mathrm{H}_{2} \mathrm{O}, 0,0714 \%$ $(\mathrm{m} / \mathrm{V} \%) \mathrm{FePO}_{4}, 0,0728 \%$ (m/V\%) $\mathrm{MnSO}_{4} \times \mathrm{H}_{2} \mathrm{O}, 0,08 \%(\mathrm{~m} / \mathrm{V} \%) \mathrm{Na}_{2} \mathrm{MoO}_{4} \times 2 \mathrm{H}_{2} \mathrm{O}, 0,0008 \%$ $(\mathrm{m} / \mathrm{V} \%) \mathrm{ZnSO}_{4} \times 7 \mathrm{H}_{2} \mathrm{O}$, **Vitaminoldat: 0,004\% (m/V\%) pantoténsav, 0,004\% (m/V\%) para-aminobenzoesav, $0,005 \%(\mathrm{~m} / \mathrm{V} \%)$ riboflavin, $0,0025 \%(\mathrm{~m} / \mathrm{V} \%)$ piridoxin, $0,00001 \%$ $(\mathrm{m} / \mathrm{V} \%)$ biotin, $0,005 \%(\mathrm{~m} / \mathrm{V} \%)$ tiamin.

Malátás táptalaj (malt extract agar, MEA): $0,5 \%(\mathrm{~m} / \mathrm{V} \%)$ malátakivonat, $0,25 \%(\mathrm{~m} / \mathrm{V} \%)$ élesztőkivonat, 1\% (m/V\%) D-glükóz, 2\% (m/V\%) agar.

Penicillium chrysogenum minimál tápoldat/táptalaj (Penicillium chrysogenum minimal medium, PCMM): 2\% (m/V\%) szacharóz, 0,3\% (m/V\%) $\mathrm{NaNO}_{3}, 0,05 \%(\mathrm{~m} / \mathrm{V} \%) \mathrm{KCl}$, 0,05\% (m/V\%) $\mathrm{MgSO}_{4} \times 7 \quad \mathrm{H}_{2} \mathrm{O}, 0,005 \%(\mathrm{~m} / \mathrm{V} \%) \quad \mathrm{FeSO}_{4} \times 7 \mathrm{H}_{2} \mathrm{O}, 0,25 \%(\mathrm{~V} / \mathrm{V} \%) \quad 1 \mathrm{M}$ $\mathrm{K}_{2} \mathrm{HPO}_{4} / \mathrm{KH}_{2} \mathrm{PO}_{4}$ puffer $(\mathrm{pH} 5,8)^{*}, 0,01 \%(\mathrm{~V} / \mathrm{V} \%)$ nyomelemoldat**, táptalaj készítése esetén 2\% (m/V\%) agar. ${ }^{*} \mathrm{~K}_{2} \mathrm{HPO}_{4} / \mathrm{KH}_{2} \mathrm{PO}_{4}$ puffer $\left(\mathrm{pH}\right.$ 5,8): $174 \mathrm{~g} / 1 \mathrm{~K}_{2} \mathrm{HPO}_{4}, 136 \mathrm{~g} / 1$ $\mathrm{KH}_{2} \mathrm{PO}_{4}$, **Nyomelemoldat: 0,1\% (m/V\%) $\mathrm{FeSO}_{4} \times 7 \mathrm{H}_{2} \mathrm{O}, 0,9 \%(\mathrm{~m} / \mathrm{V} \%) \mathrm{ZnSO}_{4} \times 7 \mathrm{H}_{2} \mathrm{O}$, 0,4\% (m/V\%) $\mathrm{CuSO}_{4} \times 5 \mathrm{H}_{2} \mathrm{O}, 0,01 \%(\mathrm{~m} / \mathrm{V} \%) \mathrm{MnSO}_{4} \times \mathrm{H}_{2} \mathrm{O}, 0,01 \%(\mathrm{~m} / \mathrm{V} \%) \mathrm{H}_{3} \mathrm{BO}_{3}, 0,01 \%$ (m/V\%) $\mathrm{Na}_{2} \mathrm{MoO}_{4} \times 2 \mathrm{H}_{2} \mathrm{O}$. 
${ }^{13} \mathbf{C} /{ }^{15} \mathbf{N}$-jelölt PCMM: PCMM tápoldatban az eredeti szén és nitrogén forrás helyett: $0,3 \%$ $\mathrm{Na}^{15} \mathrm{NO}_{3}$ és $1 \%{ }^{13} \mathrm{C}$-glükóz ( $\mathrm{m} / \mathrm{V} \%$ ) (Euriso-Top).

RPMI 1640 (Sigma-Aldrich): $0,3 \quad \mathrm{mg} / 1 \quad$ L-glutaminnal kiegészítve, $0,165 \quad \mathrm{M} \quad 4-$ morfolinpropánszulfonsav (MOPS, Sigma-Aldrich), $\mathrm{pH}$ 7,0.

Transzformáló táptalaj: $0,05 \%(\mathrm{~m} / \mathrm{V} \%) \mathrm{MgSO}_{4} \times 7 \mathrm{H}_{2} \mathrm{O}, 0,05 \%(\mathrm{~m} / \mathrm{V} \%) \mathrm{KCl}, 0,005 \%$ (m/V\%) $\mathrm{FeSO}_{4} \times 7 \mathrm{H}_{2} \mathrm{O}, 2 \%(\mathrm{~m} / \mathrm{V} \%)$ szacharóz 1\% (fedőagar) vagy 2\% (alapagar) agarral kiegészítve, $30 \%(\mathrm{~V} / \mathrm{V} \%) \mathrm{R} 1$ oldat $(\mathrm{pH} 5,8) *{ }^{*} \mathrm{R} 1$ oldat: $1 \%(\mathrm{~m} / \mathrm{V} \%) \mathrm{NaNO}_{3}, 11,6 \%$ $(\mathrm{m} / \mathrm{V} \%) \mathrm{NaCl} 75 \mathrm{mM} \mathrm{K} \mathrm{HPO}_{4} / \mathrm{KH}_{2} \mathrm{PO}_{4}$ pufferben $(\mathrm{pH} 5,8) * *$. ** $\mathrm{K}_{2} \mathrm{HPO}_{4} / \mathrm{KH}_{2} \mathrm{PO}_{4}$ puffer (pH 5,8): 13,05 g/1 K $2 \mathrm{HPO}_{4}, 10,2 \mathrm{~g} / 1 \mathrm{KH}_{2} \mathrm{PO}_{4}$.

Fedőagar: transzformáló táptalaj 1\% (m/V\%) agarral és $0,1 \%(\mathrm{~V} / \mathrm{V} \%)$ nyomelemoldattal kiegészítve.

Alapagar: transzformáló táptalaj 2\% (m/V\%) agarral és $0,1 \%(\mathrm{~V} / \mathrm{V} \%)$ nyomelemoldattal, és $0,6 \mu \mathrm{g} / \mathrm{ml}$ piritiaminnal (Sigma-Aldrich) kiegészítve.

\subsubsection{Tenyésztési körülmények}

A natív NFAP2-termelő $N$. fischeri NRRL 181 törzset CM, az rNFAP2-termelő $P$. chrysogenum-ot PCMM, míg a mikrodilúciós tesztek során alkalmazott élesztőgomba törzseket YEGK, a fonalasgomba törzseket pedig MEA táptalajon tartottuk fenn $4{ }^{\circ} \mathrm{C}$-on.

A sejt- és spóraszuszpenziók készítéséhez a gombák fenntartására alkalmazott táptalajon nevelt tenyészeteket használtuk. Az inkubációs hömérséklet az egyes törzsek igényeinek megfelelően $25{ }^{\circ} \mathrm{C}$ (A. nidulans FGSC A4, A. niger SZMC 601, $N$. fischeri NRRL 181), $30^{\circ} \mathrm{C}$ (C. albicans ATCC 10231, C. glabrata CBS 138, C. guilliermondii CBS 566, C. krusei CBS 573, C. lusitaniae CBS 6936, C. parapsilosis CBS 604, C. tropicalis CBS 94, S. cerevisiae SZMC 0644, S. pombe SZMC 0142) és $37{ }^{\circ} \mathrm{C}$ ( $R$. miehei CBS 360.92) volt. A mikrodilúciós tesztek során alkalmazott izolátumok sejt-, illetve spóraszuszpenzióihoz az élesztőgombákat 16 órán át, $30^{\circ} \mathrm{C}$-on, 160 rpm-en rázatva YPD tápoldatban növesztettük, a fonalasgombák esetében pedig 4 napos tenyészetek felületéröl spórapufferrel (SP) lemosott és vattás tölcséren átszürt konídiumokat használtunk.

Natív NFAP2 termeléséhez a $N$. fischeri NRRL 181 törzset PCMM tápoldatban 25 ${ }^{\circ} \mathrm{C}$-on, 7 napon át, 210 rpm-en rázatva, míg a heterológ expresszió során a $P$. chrysogenum Lpaf/nfap2 törzset PCMM tápoldatban $25{ }^{\circ} \mathrm{C}$-on, 4 napon át, $210 \mathrm{rpm}$-en rázatva növesztettük. 
Az antifungális hatásvizsgálatokhoz LCM és RPMI 1640 tápoldatot használtunk. Az LCM táboldatban végzett tesztek során az inkubációs hőmérséklet fajtól függően $25^{\circ} \mathrm{C}(A$. nidulans FGSC A4, A. niger SZMC 601, $N$. fischeri NRRL 181), $30^{\circ} \mathrm{C}(C$. albicans ATCC 10231, C. glabrata CBS 138, C. guilliermondii CBS 566, C. krusei CBS 573, C. lusitaniae CBS 6936, C. parapsilosis CBS 604, C. tropicalis CBS 94, S. cerevisiae SZMC 0644, S. pombe SZMC 0142), vagy $37^{\circ} \mathrm{C}$ (R. miehei CBS 360.92) volt, RPMI 1640 esetében $35^{\circ} \mathrm{C}$.

\subsection{Alkalmazott pufferek és oldatok}

\section{Spórapuffer (SP):}

- $0,9 \%(\mathrm{~m} / \mathrm{V} \%) \mathrm{NaCl}$

- $0,01 \%(\mathrm{~V} / \mathrm{V} \%)$ Tween 80

\section{A DNS-tisztítás során használt oldatok:}

- $10 \%(\mathrm{~m} / \mathrm{V} \%)$ nátrium-lauril-szarkozinát

- $5 \mathrm{M} \mathrm{Na}$-acetát (pH 5,5)

- $70 \%(\mathrm{~V} / \mathrm{V} \%)$ etil-alkohol

\section{Nukleinsav-gélelektroforézishez használt oldatok:}

- TAE puffer: $40 \mathrm{mM}$ Tris-HCl (pH 7,6), 1 mM Na 2 EDTA

- Agaróz gél: 0,7 vagy $1,5 \%(\mathrm{~m} / \mathrm{V} \%)$ agaróz, TAE pufferben

- $1 \times S Y B R$ Safe (Life Technologies) DNS festék törzsoldat agaróz gélben

- Mintapuffer: $6 \times$ DNS mintapuffer (Thermo Scientific)

- Molekulasúlymarker: GeneRuler 50 bp DNA Ladder (Thermo Fisher Scientific/Fermentas); $p U C$ Mix Marker (Thermo Fisher Scientific): steril desztillált víz: 6×DNS mintapuffer: molekulasúlymarker 4:1:1 arányú elegye

\section{Fehérjetisztításhoz használt oldatok:}

- Ekvilibráló puffer (1\% (V/V\%) $1 \mathrm{M} \mathrm{Na}_{2} \mathrm{HPO}_{4} / \mathrm{NaH}_{2} \mathrm{PO}_{4}$ puffer $(\mathrm{pH} 6,6)^{*}, 0,5 \%$ (V/V\%) $5 \mathrm{M} \mathrm{NaCl}, 0,01 \%(\mathrm{~V} / \mathrm{V} \%$ ) 0,5 M etilén-diamin-tetraecetsav (EDTA), $* \mathrm{Na}_{2} \mathrm{HPO}_{4} / \mathrm{NaH}_{2} \mathrm{PO}_{4}$ puffer (pH 6,6): 37,5\% (V/V\%)1 $\mathrm{M} \mathrm{Na}_{2} \mathrm{HPO}_{4}, 62,5 \%(\mathrm{~V} / \mathrm{V} \%) 1$ $\mathrm{M} \mathrm{NaH}_{2} \mathrm{PO}_{4}$ )

- $20 \mathrm{mM} \mathrm{NaH}_{2} \mathrm{PO}_{4}$ puffer

- $20 \mathrm{mM} \mathrm{Na}_{2} \mathrm{HPO}_{4}$ puffer

- $4 \mathrm{M} \mathrm{NaCl}$ oldat 


\section{Fehérje-gélelektroforézishez használt anyagok:}

- Elöre elkészített 4-12\%-os fehérjegél (NuPAGE ${ }^{\mathrm{TM}}$ Novex ${ }^{\mathrm{TM}} 4-12 \%$ Bis-Tris Protein Gels, $1.5 \mathrm{~mm}$, 10-well; Thermo Fisher Scientific)

- 1× futtatópuffer: NuPAGE® MES Running Buffer (pH 7,3) (Thermo Fisher Scientific)

- Fehérje-molekulasúlymarker: SeeBlue ${ }^{\mathrm{TM}}$ Plus2 Pre-stained Protein Standard (Thermo Fisher Scientific)

- Low-range Amersham Rainbow Marker (GE Healthcare Life Sciences)

\section{Poliakrilamid gél festéséhez használt oldatok:}

Coomassie Brilliant Blue R-250 festés:

- Coomassie-kék festőoldat: 0,63\% (m/V\%) Coomassie Brilliant Blue R-250, 45\% (V/V\%) metanol, 10\% (V/V\%) ecetsav

- Mosó oldat 1: 40\% (V/V\%) metanol, 7\% (V/V\%) ecetsav

- Mosó oldat 2: 5\% (V/V\%) metanol, 3,5\% (V/V\%) ecetsav

Ezüst-festés:

- Fixáló oldat: 50\% (V/V\%) metanol, 12\% (V/V\%) ecetsav, 0,05\% (V/V\%) formaldehid

- Szenzitizáló oldat: $0,02 \%(\mathrm{~m} / \mathrm{V} \%) \mathrm{Na}_{2} \mathrm{~S}_{2} \mathrm{O}_{3}$

- Ezüst-nitrát oldat: $0,2 \%(\mathrm{~m} / \mathrm{V} \%) \mathrm{AgNO}_{3}$ oldat

- Elöhívó oldat: 0,0004\% (m/V\%) $\mathrm{Na}_{2} \mathrm{~S}_{2} \mathrm{O}_{3}, 6 \%(\mathrm{~m} / \mathrm{V} \%) \mathrm{NaCO}_{3}, 0,05 \%$ (V/V\%) formaldehid

Tömegspektrometriás méréseknél használt oldatok:

- $25 \mathrm{mM} \mathrm{NH}_{4} \mathrm{HCO}_{3}(\mathrm{pH} 8,0)$

- 10 mM DTT

- $55 \mathrm{mM}$ jódacetamid

- $25 \mathrm{mM} \mathrm{NH}_{4} \mathrm{HCO}_{3}+0,1 \mu \mathrm{g}$ tripszin (Promega)

- „A” eluens: desztillált víz, 0,1% (V/V\%) hangyasav

- „B” eluens: acetonitril (ACN), 0,1\% (V/V\%) hangyasav

\section{RP-HPLC méréseknél használt oldatok:}

- „A” eluens: desztillált víz, 0,1% (V/V\%) trifluorecetsav (TFA)

- „B” eluens: desztillált víz, 80\% (V/V\%) ACN, 0,1\% (V/V\%) TFA 
A $P$. chrysogenum $\Delta p a f$ transzformálása során használt pufferek és oldatok:

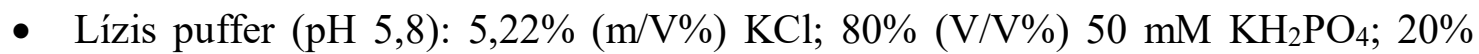
(V/V\%) $50 \mathrm{mM} \mathrm{K}_{2} \mathrm{HPO}_{4}$

- $0,7 \mathrm{M} \mathrm{KCl}$

- $\mathrm{KCM}(\mathrm{pH} 5,8): 5,22 \%(\mathrm{~m} / \mathrm{V} \%) \mathrm{KCl} ; 0,8 \%$ (m/V\%) $\mathrm{CaCl}_{2} ; 0,2 \%$ (m/V\%) MOPS; $\mathrm{pH}$ beállítás $0,1 \mathrm{M} \mathrm{KOH-val}$

- PCM (pH 5,8): 0,8\% (m/V\%) $\mathrm{CaCl}_{2} ; 0,2 \%$ (m/V\%) MOPS; 50\% (m/V\%) Polietilénglikol (PEG) 6000 vagy 8000; pH beállítás $1 \mathrm{M} \mathrm{NaOH-val}$

- TE puffer (pH 8,8): 50 mM Tris-HCl (pH 8,8), 10 mM Na 2 EDTA (pH 8,8); pH beállítás $\mathrm{NaOH}-\mathrm{val}$

A transzformánsok NFAP2 termelésének vizsgálata során végzett fehérje gélelektroforézishez használt oldatok (18\% fehérjegél):

- Gyüjtőgél: 0,1\% ProSieve 50 Gel Solution (Lonza); 0,13\% (V/V\%) 1 M Tris-HC1 ( $\mathrm{pH} 6,8) ; 0,005 \%$ (V/V\%) 10\%-os ammónium-peroxo-diszulfát (APS); 0,005\% (V/V\%) 10\%-os SDS; 0,0008\% (V/V\%) tetrametil-etilén-diamin (TEMED)

- Szeparálógél: 0,36\% ProSieve 50 Gel Solution (Lonza); 0,25\% (V/V\%) 1,5 M Tris$\mathrm{HCl}(\mathrm{pH} 8,8) ; 0,01 \%$ (V/V\%) 10\%-os APS; 0,01\% (V/V\%) 10\%-os SDS; 0,0004\% (V/V\%) TEMED

- 1×futtatópuffer: NuPAGE® MES Running Buffer (pH 7,3) vagy Novex ${ }^{\mathrm{TM}}$ TrisGlycine SDS Running Buffer (Life Technologies)

- Fehérje-molekulasúlymarker: SeeBlue ${ }^{\mathrm{TM}}$ Plus2 Pre-stained Protein Standard (Thermo Fisher Scientific)

\section{A kémiai peptidszintézisnél használt oldatok:}

Natív kémiai ligálás:

- $\quad 0,1 \mathrm{M}$ ammónium-acetát $\left(\mathrm{NH}_{4} \mathrm{OAc}\right)$ puffer $+3 \%(\mathrm{~V} / \mathrm{V} \%)$ tiofenol

- $6 \mathrm{M}$ guanidin-hidroklorid

- $10-15 \%(\mathrm{~V} / \mathrm{V} \%) \mathrm{ACN}$

Oxidatív feltekeredés:

- 0,1 M ammónium-acetát $\left(\mathrm{NH}_{4} \mathrm{OAc}\right)$ puffer $+1 \mathrm{mM}$ glutation $(\mathrm{GSH})+1 \mathrm{mM}$ glutation-diszulfid (GSSG) (pH 7,5) 


\section{Mikroszkópos vizsgálatoknál használt oldatok:}

Metabolikus aktivitás vizsgálata:

- $5 \mu \mathrm{M}$ FUN-1 festék (Life Technologies)

- $10 \mathrm{mM}$ HEPES puffer (pH 7,2) (Sigma-Aldrich)

Apoptózis detektálása:

- Annexin V-FITC Apoptosis Detection Kit (Sigma-Aldrich)

Membránintegritás vizsgálata:

- $5 \mu \mathrm{g} / \mathrm{ml}$ propídium-jodid (PI, Sigma-Aldrich) LCM-ben oldva

- $70 \%(\mathrm{~V} / \mathrm{V} \%)$ etanol LCM-ben oldva

\subsection{Alkalmazott indítószekvenciák}

Az nfap2 cDNS felszaporításához használt indítószekvenciák

NFAP2F: 5'-GGCCGCTGAGGCCGGTGT-3' (Tm: 64,1 ${ }^{\circ} \mathrm{C}$ )

NFAP2R: 5'-GGCCAAGCTTCGAGAATCACAGG-3' (Tm: 61,5 $\left.{ }^{\circ} \mathrm{C}\right)$

A paf 5'- és 3'-UTR végü konstrukció felszaporításához használt indítószekvenciák

1stF: 5'-GGCCCCATGGTGGTAAACAAGTAGTG-3' (Tm: 62,8 ${ }^{\circ} \mathrm{C}$ )

1stR: 5'-GGTGGCGGCCGCTCTAGAACTAG-3’ (Tm: 64,8 $\left.{ }^{\circ} \mathrm{C}\right)$

\subsection{Alkalmazott módszerek}

\subsubsection{NFAP2 izolálása és azonosítása}

\subsubsection{Fehérjetermelés}

A natív NFAP2 termeléséhez $2 \times 10^{7} N$. fischeri NRRL 181 konídiumot $10 \mathrm{db}, 200$ ml MM tápoldatot tartalmazó, egy literes Erlenmeyer-lombikba oltottunk, majd $25{ }^{\circ} \mathrm{C}$-on, 210 rpm-en folyamatos rázatva 7 napig növesztettük.

Az NFAP2 heterológ expressziója során $2 \times 10^{8} \quad P$. chrysogenum Apaf/nfap2 konídiumot $10 \mathrm{db}, 200 \mathrm{ml}$ PCMM tápoldatot tartalmazó $500 \mathrm{ml}$-es Erlenmeyer-lombikba oltottunk, majd $25{ }^{\circ} \mathrm{C}$-on, 210 rpm-en folyamatosan rázatva 4 napig növesztettük. $\mathrm{A}^{13} \mathrm{C} /{ }^{15} \mathrm{~N}$ jelölt NFAP2 termelése, a tápoldat kivételével $\left({ }^{13} \mathrm{C} /{ }^{15} \mathrm{~N}\right.$-jelölt PCMM), az rNFAP2 esetében leírt körülmények között történt. 


\subsubsection{Az NFAP2 tisztítása}

A tisztítás során a fermentléböl papírfilteren (Rotilabo-round filters, type 111A, Carl Roth) keresztül történő vákuum-szüréssel távolítottuk el a micéliumot. A fermentlevet centrifugáltuk $\left(10000 \times \mathrm{g}, 30\right.$ perc, $\left.17^{\circ} \mathrm{C}\right)$ majd redős papírfilteren (Fisherbrand QL115 folded filter paper, Fisher Scientific) keresztül ismét átszürtük. A felülúszót ultraszüréssél $30 \mathrm{kDa}$ alatti és $30 \mathrm{kDa}$ feletti frakciókra különítettük el (Amicon Stirred Cell, 400ml és Ultracell $30 \mathrm{kDa}$ Ultrafiltartion Discs, regenerated cellulose, Millipore). Az NFAP2-t tartalmazó $30 \mathrm{kDa}$ alatti frakciót kationcserés oszlopon, (Bio-Scale ${ }^{T M}$ Mini Macro-Prep ${ }^{\circledR}$ High S column, Bio-Rad) DuoFlow folyadékkromatográfiás készülék segítségével (Duoflow Fast Protein Liquid Chromatography (FPLC) System, Bio-Rad) tisztítottuk. Az oszlopot 25 mM NaCl-ot és 0,15 mM EDTA-t tartalmazó 10 mM Na $2 \mathrm{HPO}_{4} / \mathrm{NaH}_{2} \mathrm{PO}_{4}$ pufferrel $(\mathrm{pH} 6,6)$ ekvilibráltuk. A felkötött fehérjéket $10 \mathrm{mM} \mathrm{Na}_{2} \mathrm{HPO}_{4} / \mathrm{NaH}_{2} \mathrm{PO}_{4}(\mathrm{pH} 6,6)$ pufferben készített $\mathrm{NaCl}$ grádienssel (0,0-2 M) eluáltuk 1,2 ml/perc átfolyási sebességgel.

\subsubsection{NFAP2 tisztítás ellenőrzése}

A tisztítás eredményeként nyert, fehérjét tartalmazó frakciókat poliakrilamid gélelektroforézissel (SDS-PAGE) ellenőriztük. A fehérje-gélelektroforézist 4-12\%-os BisTris gélen $(N u P A G E \AA$, Novex $\AA$, 4.12\% Bis-Tris Protein Gel, $1.0 \mathrm{~mm}, 10$ well, Life Technologies) végeztük el, 1×MES (2-(N-morfolino)etánszulfonsav, Thermo Fisher Scientific) futtatópufferben. Az elválasztást $150 \mathrm{~V}$ feszültségen 45 percig végeztük. A protein sávok megjelenítésére Coomassie Brilliant Blue $R-250$ - és ezüst-festést alkalmaztunk.

\section{Coomassie Brilliant Blue $R-250$ festés}

A fehérje géleket 1 órán át Coomassie-kék festőoldatban rázattuk $45 \mathrm{rpm}$ sebességgel. A festőoldat eltávolítását követően a géleket 2 órán át kétszer cserélve az 1. mosóoldatban, majd 1 órán át kétszer cserélve a 2. mosóoldatban lassan rázattuk (45rpm).

\section{$\underline{\text { Ezüst-festés }}$}

A géleket 2 órán keresztül fixáló oldatban rázattuk (45 rpm). A fixáló oldat leöntését követően háromszor 20 percig $20 \%$ (V/V\%) etanollal, majd 2 percen át szenzitizáló oldattal kezeltük. Kétszer egy perces desztillált vízzel történő mosás után 20 percig, $0,2 \%(\mathrm{~m} / \mathrm{V} \%)$ $\mathrm{AgNO}_{3}$ oldatban rázattuk (45 rpm), majd újabb desztillált vizes mosást követően előhívóoldatban kevertettük (45 rpm) a géleket a fehérjesávok megjelenéséig. A sávok 
megjelenése után $5 \%$-os (V/V\%) ecetsavval állítottuk le a reakciót (10 perc, 45 rpm rázatás mellett). Végül a géleket desztillált vízzel öblítettük.

\subsubsection{NFAP2 sómentesítése és liofilezése}

A tisztítás során gyüjtött, fehérjét tartalmazó frakciókat egyesítettük, és dialízismembránban (Snake Skin ${ }^{T M}$ dialysis tubing, 3,5 K MWCO, Thermo Fisher Scientific) 1:400 arányban bidesztillált vízzel szemben 8 órán keresztül, $4{ }^{\circ} \mathrm{C}$-on sómentesítettük. A dializált mintát liofilizáltuk, majd a fehérjét $5 \mathrm{ml}$ bidesztillált vízben feloldottuk. Újabb dialízist követően (1:2000 arányban bidesztillált vízzel szemben; Snake Skin ${ }^{T M}$ dialysis tubing, 3,5 K MWCO, Thermo Fisher Scientific) a fehérjeoldatot fecskendőszürő (MillexGV, PVDF, pore size: $0.22 \mu m$; low protein binding, Millipore) segítségével sterilre szürtük.

\subsubsection{Az NFAP2 koncentrációjának meghatározása}

Az NFAP2 vizes oldatának koncentrációját spektrofotometriás méréssel 280 nm-en $\left(\mathrm{OD}_{280}\right)$, az NFAP2 moláris extinkciós koefficiensének $(\varepsilon=1,842)$ figyelembevételével határoztuk meg a következő képlet segítségével:

$$
\mathrm{OD}_{280} / \varepsilon=\text { fehérje }(\mathrm{mg} / \mathrm{ml})
$$

\subsubsection{Az NFAP2 azonosítása tömegspektrometriával}

Az NFAP2 tömegspektrometriás azonosítása enzimatikus emésztéses módszeren alapult, és egy nanoelektrospray ionforrással felszerelt $Q$-TOF Premier tömegspektrométer (kvadrupól-repülési idő tömegspektrométer, Micromass ${ }^{\circledR} Q-T O F$, Waters) segítségével történt. $10 \mu \mathrm{l}, 1 \mu \mathrm{g} / \mu 1$ fehérjét tartalmazó, protein oldathoz hozzámértük $25 \mathrm{mM} \mathrm{NH}_{4} \mathrm{HCO}_{3}$ t (pH 8) tartalmazó puffert, $10 \mathrm{mM}$ DTT a diszulfid-hidak redukálásához és $55 \mathrm{mM}$ jódacetamidot a minta alkilálásához. A redukált és alkilált fehérjét C184-et tartalmazó ZipTip pipettaheggyel (Millipore) tisztítottuk és $25 \mathrm{mM} \mathrm{NH}_{4} \mathrm{HCO}_{3}$-ban oldott $0,1 \mu \mathrm{g}$ tripszin (Promega) oldattal emésztettük 16 órán át, $37^{\circ} \mathrm{C}$-on. Az emésztett minták analízise egy ultra-nagyhatékonyságú folyadékkromatográffal (Nano Aquity Ultraperformance Liquid Chromatography System, UPLC, Waters) összekapcsolt Q-TOF MS készülék segítségével történt BEH130 C18 oszlopon (Waters, oszlophossz $250 \mathrm{~mm}$, oszlopátmérö: $75 \mu \mathrm{m}$, részecskeméret: 1,7 $\mu \mathrm{m})$. A mozgó fázis kiindulási összetétele 3\% (V/V\%) „B eluens” volt, amelyet 40 perc alatt 40\%-ra (V/V\%) növeltünk $350 \mathrm{nl} /$ perc áramlási sebesség mellett. Az enzimatikus hasításból származó adatokat a ProteinLynx Global Server (Waters) 
segítségével dolgoztuk fel. Az adatfeldolgozás eredményeként egy olyan tömeglistát kaptunk, amely tartalmazta az enzimatikus emésztés során nyert peptidek tömegének listáját, valamint azok tandem tömegspektrometriás (MS/MS) fragmentálásával kapott, az egyes peptidekhez tartozó fragmenslistát is. Ez utóbbi felhasználásával meghatároztuk a peptidek rész- vagy szerencsés esetben teljes szekvenciáját. Az adathalmazt egy kereső szoftverrel elemeztük (Mascot Search Engine, NCBInr database). Ez a szoftver az adatbázisban található fehérje szekvenciák között oly módon képes keresni, hogy a mért tömegeket és az MS/MS mérésekből meghatározott szekvenciákat összeveti az adatbázisból a (elméleti) tripszinhasítás eredményeként valószínüsített szekvenciákkal.

A tömegspektrometriás méréseket és az adatok kiértékelését Dr. Kele Zoltán, a Szegedi Tudományegyetem, Általános Orvostudományi Kar, Orvosi Vegytani Intézetének munkatársa végezte el.

\subsubsection{In silico vizsgálatok}

Az érett NFAP2 molekulatömegének, izoelektromos pontjának, töltésének és peptid fragmenseinek in silico meghatározását az ExPAsy ProtParam tool (Gasteiger és mtsi., 2005) és a Protein Calculator (v3.4) szerver (The Scripps Research Institute; http://www.scripps.edu/ cdputnam/protcalc.html) segítségével végeztük el. Az NFAP2 másodlagos szerkezetét a PSIPRED (v3.3) Protein Analysis Workbench szoftver (Buchan és mtsi., 2013), diszulfid-híd mintázatát a DISULFIND Cysteines Disulfide Bonding State and Connectivity Predictor szerver (Ceroni és mtsi., 2006), a szignálszekvencia hasítóhelyét pedig a SignalP1 4.1 szerver segítségével határoztuk meg (Petersen és mtsi., 2011). A 2-es és 4-es szNFAP2 peptidfragmensek kevert aminosavsorrendü változatait a Sequence Manipulation Suite random shuffle protein generátorával készítettük el (Stothard, 2000).

\subsubsection{Az NFAP2 és homológ proteinek filogenetikai analízise}

Az antifungális fehérjeszekvenciák vizsgálata során a $M E G A$ v7.0 és BioEdit programokat használtuk (Hall, 1999; Kumar és mtsi., 2016). Az NFAP2 homológok keresését a Basic Local Alingment Search Tool (BLAST; Pevsner, 2009) segítségével a National Center for Biotechnology Information (NCBI), az Expert Protein Analysis System (ExPASy) és a Joint Genome Institute (JGI) adatbázisokban végeztük el. A filogenetikai analízisbe az összes korábban izolált és jellemzett cgAFP-t és azok feltételezett homológjait vontuk be. A szekvenciák igazítását a $P R A N K$ v. 140110 szoftver segítségével végeztük el 
(Löytynoja és Goldman, 2008). A hiányos pozíciókat a FastGap v 1.2 -vel bináris kóddá alakítottuk át (Borchsenius, 2009). A maximális valószínűség-elemzést (MaximumLikelihood, ML) a RAxML v8.2.10 verziójával készítettük (Stamatakis, 2014). Az analízist a protein evolúció WAG-modellje alapján végeztük el gamma-eloszlású rátaheterogenitás és 1000 bootstrap-replikátum alkalmazásával. A számításokat partícionált adatsorokon hajtottuk végre, melyben az első partíció a fehérje szekvencia, a második pedig a FastGap v 1.2 szoftverrel létrehozott bináris kód volt.

A filogenetikai analízisben Dr. Kocsubé Sándor, a Szegedi Tudományegyetem, Természettudományi és Informatikai Kar, Mikrobiológiai Tanszékének munkatársa volt segítségünkre.

\subsubsection{Az rNFAP2-termelő $P$. chrysogenum-alapú heterológ expressziós rendszer létrehozása}

\subsubsection{Az érett NFAP2-t kódoló gén pSK275paf vektorba történő klónozása}

$\underline{\text { Az } n f a p 2 \text { cDNS felszaporítása }}$

Az nfap2, a paf proszekvenciával és a paf 3'-UTR-rel részben átfedő cDNS-ét a $B b v C I$ és HindIII restrikciós endonukleázok hasítóhelyeit tartalmazó NFAP2F és NFAP2R indítószekvenciák és Q5 High Fidelity DNA Polymerase (New England Biolabs) segítségével szaporítottuk fel a pUC57 plazmid EcoRV restrikciós helyére beágyazott szintetikus konstrukcióból (GenScript USA Inc.). A szintetikus konstrukció nukleotid sorrendje (5'-3') a 4. ábrán látható.

$$
\downarrow \text { BbvCI } \quad \text { nfap2 }
$$

GGCCGCTGAGGCCGGTGTCCTGATCGCCACCTCCCCCTACTACGCCTGCAACTGCC CCAACAACTGCAAGCACAAGAAGGGCTCCGGCTGCAAGTACCACTCCGGCCCCT CCGACAAGTCCAAGGTCATCTCCGGCAAGTGCGAGTGGCAGGGCGGCCAGCTCA ACTGCATCGCCACCTAAATGGTCTCTGCGATCACCAGGGCATTTAATGGTTTTTGGTT CCCTTCTTGTTGGTGATATGCGAGATGCCCTGTGATTCTCGAAGCTTGGCC

4. ábra. A pUC57 plazmid EcoRV restrikciós helyére beágyazott szintetikus konstrukció nukleotid sorrendje. Dőlt piros betűkkel jelöltük a paf proszekvenciával és kékkel a paf 3'-UTR-rel részben átfedő nukleotidokat. Szürkével emeltük ki az érett NFAP2-t kódoló cDNS-t. A BbvCI és a HindIII restrikciós endonukleázok hasítóhelyeit aláhúzással jelöltük. 
A polimeráz láncreakciót MJ Mini ${ }^{\mathrm{TM}}$ Personal Thermal Cycler (Bio-Rad) készülékkel végeztük az 5. táblázatban látható reakciókörülmények között. A reakciót $25 \mu 1$ végtérfogatban mértük össze a következők szerint:

- $1 \times Q 5$ High Fidelity DNA Polymerase puffer (New England Biolabs)

- $\quad 0,5 \mathrm{mM}$ dNTP mix (New England Biolabs)

- $0,4 \mu \mathrm{M}$ NFAP2F és NFAP2R indítószekvencia

- $2,5 \mathrm{mM} \mathrm{MgCl} 2$

- 10 ng plazmid DNS

- 2 U Q5 High Fidelity DNS Polymerase (New England Biolabs)

A PCR-terméket gélelektroforézissel ellenőriztük 1,5\%-os (m/V\%), SYBR Safe-fel (Invitrogen) festett agaróz gélen.

Az érett NFAP2-t kódoló cDNS klónozása pGEM-Tnfap vektorba

Az érett NFAP2-t kódoló cDNS-t tartalmazó felszaporított 273 bp amplikont, egy korábban elkészített, pGEM-Tnfap vektorba klónoztuk (Sonderegger és mtsi., 2016). A pGEM-Tnfap vektorban jelenlévő, a paf részleges 5'- és 3'-UTR régióval határolt, a paf preproszekvenciához fúzionált $n f a p$ cDNS-t $B b v C I$ és HindIII restrikciós endonukleázokkal (New England Biolabs) kihasítottuk, majd a helyére az nfap2 cDNS-t klónoztuk. Az így létrehozott vektor a paf részleges 5'- és 3'-UTR határolt, a paf preproszekvenciához fúzionált nfap2 cDNS-t tartalmazta (pGEM-Tnfap2 vektor).

\section{A paf 5'- és 3'-UTR régiókkal szegélyezett konstrukció felszaporítása}

A paf részleges 5'- és 3'-UTR régiókkal szegélyezett konstrukciót a BspMI és NotI restrikciós endonukleázok hasítóhelyeit tartalmazó 1stF és 1stR indítószekvenciák segítségével amplifikáltuk a pGEM-Tnfap2 vektorból. A felszaporított DNS szakasz nukleotid sorrendje (5'-3') az 5. Ábrán látható. A polimeráz láncreakciót $M J M i n i^{\mathrm{TM}}$ Personal Thermal Cycler (Bio-Rad) készülékkel végeztük az 5. táblázatban látható reakciókörülmények között és a reakciót $25 \mu$ végtérfogatban, Q5 High Fidelity DNA Polymerase segítségével (New England Biolabs) mértük össze a fent leírtak szerint. Az 1033 bp méretü PCR-terméket gélelektroforézissel ellenőriztük 1,5\%-os (m/V\%), SYBR Safe-fel (Invitrogen) festett agaróz gélen. 


$$
\downarrow \text { BspMI }
$$

GGCCCCATGGTGGTAAACAAGTAGTGCATCTTACCCCGGAGGCTGAAGCAGGTAAGG GATTTTGGAGAGACCCCACCCGTAAGAATATACCAGCCAAGAGGTCCAGTATCCTGAA GTATGTGAGGCATTAATGTCATTGGAGAAGTCATGCAATCCATAAGCTGCCACCCCCA AGATGACTGCATTGGACCTGAGCATTGTATGTGTCACCTTTCACACAGAGCTCATGAT CTGGTTTATAAAGGCGGCTTCATGACCCTCAATTCCATATAGTATCACTCCCATCACAG CATTTCGATATCTTCAACCACTTTAACCTTCTCCAGAGGATCATCATCTCAAGCCCTTC ATAATGCAAATCACCACAGTTGCCCTTTTTCTCTTCGCTGCAATGGGCGGGGTAGCCAC CCCCATTGAGTCTGTATCAAACGACCTCGATGCCAGGGCTGAGGCCGGTGTCCTGATCG CCACCTCCCCCTACTACGCCTGCAACTGCCCCAACAACTGCAAGCACAAGAAGGG CTCCGGCTGCAAGTACCACTCCGGCCCCTCCGACAAGTCCAAGGTCATCTCCGGC AAGTGCGAGTGGCAGGGCGGCCAGCTCAACTGCATCGCCACCTAAATGGTCTCTG CGATCACCAGGGCATTTAATGGTTTTTGGTTCCCTTCTTGTTGGTGATATGCGAGATGC CCTGTGATTCTCGAAGCTTACTACCCTACACCCACAAGGACTCGAACCAAGGACTGCT CGGTGGGTGATACATATACACCCAGTATCTATCCAGCTTCAATTTTCGGCGAATTTTGT TTCTTATTTCATAAAGACACTCGTTTGATATCTAGCTAGATATTGTTGCTCATCAACGA AATGGTTGTAGATTATCGAATATATCCAGCATCTTTTGATCGTAGTCGGAAGTGAAAT GGAGTACTATGATACGACACATGTACATTGTAAGCAGAAATAGGCTAGAGGGATAAC TATCAAACTGCTGCAGCCCGGGGGATCCACTAGTTCTAGAGCGGCCGCACC

\section{$\uparrow$ NotI}

5. ábra. A pGEM-Tnfap2 vektorból amplifikált, paf részleges 5'- és 3'-UTR régiókkal szegélyezett konstrukció nukleotid sorrendje. Lila színnel jelöltük a paf részleges 5'-UTR és kékkel a 3'-UTR régióit, dőlt piros betűkkel a paf preproszekvenciát és szürkével az érett NFAP2-t kódoló cDNS-t. A BspMI és a NotI restrikciós endonukleázok hasítóhelyeit aláhúzással emeltük ki.

5. táblázat. A PCR során alkalmazott reakciókörülmények.

\begin{tabular}{ccc}
\hline Lépések & $\begin{array}{c}\text { nfap2 cDNS felszaporítás } \\
\text { pUC57 plazmidból }\end{array}$ & $\begin{array}{c}\text { Konstrukció felszaporítás } \\
\text { pGEM-Tnfap2 vektorból }\end{array}$ \\
\hline 1. Elödenaturáció & 1 perc $30 \mathrm{mp}, 94{ }^{\circ} \mathrm{C}$ & 1 perc $30 \mathrm{mp}, 94^{\circ} \mathrm{C}$ \\
2. Denaturáció & $10 \mathrm{mp}, 94^{\circ} \mathrm{C}$ & $30 \mathrm{mp}, 94^{\circ} \mathrm{C}$ \\
3. Inditószekvencia kötödés & $15 \mathrm{mp}, 60^{\circ} \mathrm{C}$ & $21 \mathrm{mp}, 60^{\circ} \mathrm{C}$ \\
4. Láncszintézis & $15 \mathrm{mp}, 72{ }^{\circ} \mathrm{C} \rightarrow$ & $54 \mathrm{mp}, 72{ }^{\circ} \mathrm{C} \rightarrow$ \\
5. Végső láncszintézis & 2. lépés $30 \times$ & 2.1 lépés $30 \times$ \\
\hline
\end{tabular}

A pSK275nfap2 vektor létrehozása

A rendelkezésünkre álló pSK275paf vektort (Sonderegger és mtsi., 2016), amely az 1280 bp paf 5'- és 373 bp 3'- UTR határolt paf gént tartalmazza, BspMI és NotI restrikciós 
endonukleázokkal (New England Biolabs) hasítottuk és a korábban felszaporított 1033 bp hosszúságú, az érett NFAP2-t kódoló, a paf részleges 5'- és 3'-UTR régiókkal határolt cDNS-t az emésztési helyekre klónoztuk, így létrehozva a pSK275nfap2 expressziós vektort. Az elkészült vektor az 1280 bp paf 5'- és 373 bp 3'-UTR határolt, a paf gén preproszekvenciájával fúzionált nfap2 cDNS-t tartalmazta. A pSK275nfap2 expressziós vektor (6. ábra) tartalmazta továbbá a piritiamin és ampicillin rezisztencia gén kazettákat, replikációs origókat és a vektor linearizálásához szükséges NotI restrikciós endonukleáz felismerőhelyet. A pSK275nfap2 expressziós vektor létrehozásának egyes lépéseit a $\mathbf{1}$. számú melléklet foglalja össze.

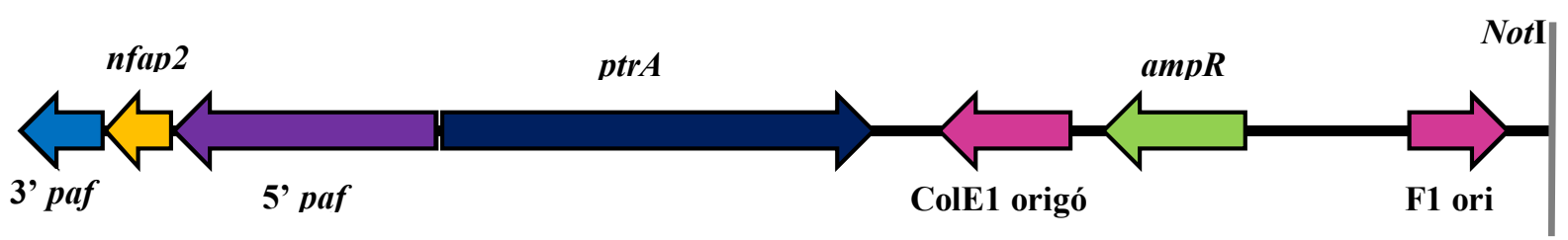

6. ábra. A pSK275nfap2 expressziós vektor. Lila színű nyíllal jelöltük az 5'-UTR és kékkel a 3'-UTR régiókat, valamint sárgával a paf gén preproszekvenciájával fúzionált $n f a p 2$ cDNS-t. PtrA jelöli a piritiamin és $a m p R$ az ampicillin rezisztencia génkazettát. Rózsaszín nyilak jelölik a replikációs origókat: ColE1 origó és F1ori egyszálú fagemid origó. NotI: a NotI restrikciós endonukleáz felismerőhelye.

Emésztési és ligálási reakciók

A plazmid DNS és PCR amplikonok emésztési reakcióit és a ligálási reakciókat a $\mathbf{6}$. táblázat foglalja össze.

6. táblázat. Az emésztési és ligálási reakciókörülmények.

\begin{tabular}{lll}
\hline & \multicolumn{1}{c}{ Emésztési reakciók } & \multicolumn{1}{c}{ Ligálási reakciók } \\
\hline Összetétel: & $-5 \mu$ g plazmid DNS vagy PCR amplikon & -300 ng inszert DNS \\
& -50 U restrikciós endonukleáz* & -100 ng linearizált plazmid DNS \\
& $-1 \times$ enzimpuffer* & -40 U T4 DNS ligáz* \\
& & $-1 \times \mathrm{T} 4$ DNS ligáz puffer* \\
\hline Reakció & 16 óra, $37^{\circ} \mathrm{C}$ & 3 óra, $25^{\circ} \mathrm{C}$ \\
Leállítás & 10 perc, $65^{\circ} \mathrm{C}$ & 10 perc, $65^{\circ} \mathrm{C}$ \\
\hline
\end{tabular}

*New England Biolabs

\subsubsection{A $P$. chrysogenum $\Delta$ paf törzs transzformációja a pSK275nfap2 plazmiddal}

A transzformációhoz $2 \times 200 \mathrm{ml} \mathrm{ACM-et} \mathrm{(egy} \mathrm{literes} \mathrm{Erlenmeyer-lombikban)} 2 \times 10^{8}$ P. chrysogenum $\Delta$ paf konídiummal oltottunk be, majd 40 órán keresztül $25^{\circ} \mathrm{C}$-on inkubáltuk 
folyamatos rázatás mellett $(210 \mathrm{rpm})$. A micéliumokat vákuum-szüréssel gézlapon összegyüjtöttük, desztillált vízzel mostuk, majd 20 g-ot $90 \mathrm{ml}$ 0,1 mg/ml Vinotaste (Novozyme) koncentrációjú lízis pufferben feloldottunk. A micéliumok pipettával történő óvatos szétmacerálása után az oldatot 60 percig $25^{\circ} \mathrm{C}$-on óvatosan rázattuk (60 rpm). Ezután az oldatot papírszürőn átszürtük (Fisherbrand QL115 folded filter paper, Fisher Scientific), majd a szürletet 10 percig $4{ }^{\circ} \mathrm{C}$-on alacsony fokozatú gyorsulás és fékezés nélkül $500 \times \mathrm{g}$-n centrifugáltuk. A leülepedett protoplasztokat $40 \mathrm{ml}$ hideg $0,7 \mathrm{M} \mathrm{KCl}$ oldatban óvatosan felszuszpendáltuk, majd az előbbiek szerint ismét centrifugáltuk. A leülepedett protoplasztokat $5 \mathrm{ml}$ hideg $0,7 \mathrm{M} \mathrm{KCl-ban} \mathrm{óvatosan} \mathrm{felszuszpendáltuk} \mathrm{és} \mathrm{ismét}$ centrifugáltuk az előbbiek szerint. Ezután az összegyült protoplasztokat $150 \mu 1 \mathrm{KCM}$ oldatba óvatosan, pipettázás nélkül felvettük és Bürker-kamra segítségével meghatároztuk a protoplasztok számát, amit a transzformációhoz $1 \times 10^{8}$ protoplaszt $/$ ml-re állítottunk be. A transzformáció során az alábbi reakcióelegyeket mértük össze:

- $\quad 100 \mu 110^{8}$ protoplaszt/ml KCM-ben

- $5 \mu \mathrm{l} 5 \mu \mathrm{g} / \mathrm{ml}$ NotI emésztett lineáris pSK275nfap2 vagy $5 \mu 1 \mathrm{ddH}_{2} \mathrm{O}$ a negatív kontroll esetén

- $\quad 25 \mu \mathrm{PCM}$

Az elegyet 30 percig jégen inkubáltuk, majd $250 \mu$ PCM-et adtunk hozzá és $25^{\circ} \mathrm{C}$ on, 20 percig inkubáltuk. Az inkubációs idő letelte után $1 \mathrm{ml} 0,7 \mathrm{M} \mathrm{KCl}$ oldatot adtunk az elegyhez. Ezt követően $172 \mu$ lelegyhez $50{ }^{\circ} \mathrm{C}$-ra melegített $4 \mathrm{ml}$ fedőagart mértünk, majd $0,6 \mu \mathrm{g} / \mathrm{ml}$ piritiaminnal kiegészített alapagart tartalmazó, $37{ }^{\circ} \mathrm{C}$-ra előmelegített Petricsészébe öntöttük és egyenletesen eloszlattuk. A regenerációs ráta számolásához a protoplasztokat 10-es léptékben hígítottuk $\left(10^{-2}-10^{-6}\right)$, az előzőekhez hasonlóan, piritiamint nem tartalmazó alapagarra szélesztettük. A csészéket maximum 10 napig $25{ }^{\circ} \mathrm{C}$-on inkubáltuk a transzformáns telepek megjelenéséig.

\section{A transzformánsok szelektálása}

A stabil transzformánsok szelektálása 3 lépésben, piritiamin (1 vagy $2 \mu \mathrm{g} / \mathrm{ml}$ ) tartalmú PCMM tápközegen történt. Elöször a transzformáció után megjelent klónok 10 telepéről konídiumot gyüjtöttünk, és szilárd, $1 \mu \mathrm{g} / \mathrm{ml}$ piritiaminnal kiegészített PCMM tápközegre pontban leoltottuk, majd 7 napon keresztül $25{ }^{\circ} \mathrm{C}$-on inkubáltuk. Ezután spóra polimeráz láncreakció segítségével igazoltuk az nfap2 genomi jelenlétét. Ennek során az első szelekciós lépés után felnőtt klónok felszínéről ismét konídiumokat gyüjtöttünk, amik DNS- 
tartalmát mikrohullámú sütőben történő melegítéssel kinyertük (8000 W, 5 perc) és $30 \mu 1$

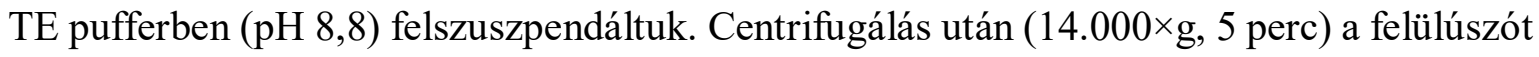
a konídiumokról eltávolítottuk, aminek $1 \mu$ l-ét alkalmaztuk a polimeráz láncreakcióban az 5.5.4.1. fejezetben ismertetett, az nfap2 cDNS felszaporítása során alkalmazott reakciókörülményekkel. 1,5\% (m/V\%) agaróz gélen vizsgáltuk a 273 bp méretü amplikonok megjelenését.

Az első szelekciós lépés után a transzformánsnak bizonyult klónok konídium szuszpenziójából 10-es léptékü hígítási sort készítettünk SP-ben, majd a hígítási sor negyedik, ötödik és hatodik tagjából 10-10 $\mu \mathrm{l}-\mathrm{t} 10 \mathrm{ml}, 2 \mu \mathrm{g} / \mathrm{ml}$ piritiaminnal kiegészített PCMM tápközegre szélesztettünk. A tenyészeteket 7 napon keresztül $25{ }^{\circ} \mathrm{C}$-on inkubáltuk. A telepek megjelenése után ezt a lépést még egyszer megismételtük, majd az NFAP2 termelési vizsgálatokhoz további 10 klónt választottunk ki.

\subsubsection{Az NFAP2 termelésre legalkalmasabb törzs kiválasztása}

Az NFAP2 termelési kísérletekhez kiválasztott 10 klónból konídium szuszpenziót készítettünk SP-ben, majd egyenként 200 ml PCMM-et tartalmazó 500 ml-es Erlenmeyerlombikba $2 \times 10^{8}$ konídiumot oltottunk. A 10 eltérő transzformánssal leoltott lombikot 4 napig, $25{ }^{\circ} \mathrm{C}$-on, $210 \mathrm{rpm}$ rázatás mellett inkubáltuk. A rázatott tenyészetek felülúszójából 48, 72 és 96 óra után mintát vettünk, centrifugáltuk $(10000 \times \mathrm{g}, 15$ perc), majd az így nyert sejtmentes felülúszók fehérjetartalmát 18\%-os poliakrilamid, bis-poliakrilamid fehérjegélen vizsgáltuk, $1 \times$ tris-glicin futtatópuffer (Thermo Fisher Scientific) használatával. Az elválasztást $150 \mathrm{~V}$ feszültségen 90 percig végeztük. A gélek fehérjetartalmát Coomassie Brilliant Blue-R250 festéssel tettük láthatóvá.

\subsubsection{Az nfap2 genomi jelenlétének bizonyítása az NFAP2 termelő törzs kiválasztásához}

A fermentlevek szürése után genomi DNS-t tisztítottunk a visszamaradó micéliumból és az 5.5.4.1. fejezetben ismertetett, az nfap2 cDNS felszaporítása során alkalmazott PCR-rel megegyező reakcióval bizonyítottuk az nfap2 genomi jelenlétét. A 273 bp méretü PCR-termékeket gélelektroforézissel ellenőriztük 1,5\% (m/V\%) agaróz gélen. Az nfap2 genomi jelenlétét mutató és a fehérjegél alapján a legjobban termelő törzset használtuk fel az rNFAP2 nagy mennyiségben történő előállítására. 


\section{$\underline{\text { A genomi DNS tisztítása }}$}

A micéliumokat folyékony nitrogénben történt fagyasztás után dörzsmozsárban tártuk fel, majd $300 \mu 1$ 10\%-os (m/V\%) nátrium-lauril-szarkozinát oldatot adtunk a mintákhoz és azokat 1 percig vortexeltük. Következő lépésben a mintákhoz 1-1 $\mu 1$ RNaseA$\mathrm{t}(10 \mathrm{mg} / \mathrm{ml})$ adtunk, és 1 percig vortexeltük. Ezt követően a mintákat 10 percig $65^{\circ} \mathrm{C}$-on inkubáltuk, és $4{ }^{\circ} \mathrm{C}$-on 10 percig hütöttük. A hütés után $300 \mu 15 \mathrm{M}$ nátrium-acetátot mértünk a mintákhoz, 1 percig vortexeltük, majd 15 percig 1400×g-n, szobahőmérsékleten centrifugáltuk. A felülúszót Eppendorf-csövekbe mértük át, majd $500 \mu 1$ hideg izopropanol hozzámérését követően elkevertük és 10 perc szobahőmérsékleten történő inkubáció után 20 percig $1400 \times$ g-n, szobahőmérsékleten centrifugáltuk. A centrifugálás után a felülúszót eltávolítottuk, a kicsapódott DNS-t $500 \mu$ 70\%-os (V/V\%) hideg etanollal mostuk és 5 percig $1400 \times$ g-n, szobahőmérsékleten centrifugáltuk. A felülúszó eltávolítását követően a csapadékot beszárítottuk majd $30 \mu$ desztillált vízben visszaoldottuk. A genomi DNS kivonásának sikerességét gélelektroforézissel ellenőriztük $0,7 \%(\mathrm{~m} / \mathrm{V} \%)$ agaróz gélen.

\subsubsection{Az NFAP2 és peptidfragmenseinek kémiai szintézise}

Az szNFAP2-t és peptidfragmenseit, valamint ezek aminosavsorrend kevert változatait szilárd fázisú peptidszintézissel állítottuk elő Boc vagy Fmoc kémiával N,N'diciklohexil-karbodiimid (DCC)/benzotriazol-1-ol-hidrát (HOBt) kapcsolás alkalmazásával. A tioészter-részt (Fr-2 fragmens) Cys-SH gyantán szintetizáltuk (Váradi és mtsi., 2013).

\section{$\underline{\text { Natív kémiai ligálás }}$}

A peptid fragmentek natív kémiai ligálását $6-8 \mathrm{mg} / \mathrm{ml}$ peptid koncentrációjú, 3\% (V/V\%) tiofenolt tartalmazó 0,1 M ammónium-acetát $\left(\mathrm{NH}_{4} \mathrm{OAc}\right)$ pufferben $(\mathrm{pH} 7,5)$ hajtottuk végre $25^{\circ} \mathrm{C}$-on. A reakciót analitikai RP-HPLC-vel követtük nyomon. A ligáció minden esetben 3-4 óra alatt befejeződött. A csapadékot 10-15\% (V/V\%) ACN és $6 \mathrm{M}$ végkoncentrációjú guanidin-hidroklorid hozzáadásával oldottuk fel. Ezután a reakcióelegyet szürtük és félpreparatív RP-HPLC-vel tisztítottuk.

A proteinek és peptidek oxidatív feltekeredése

A tisztított ligációs termékek tiol-csoportjainak oxidációját $0,1 \mathrm{M}$-os, $1 \mathrm{mM}$ glutationt (GSH) és $1 \mathrm{mM}$ glutation-diszulfidot (GSSG) tartalmazó $\mathrm{NH}_{4} \mathrm{OAc}$ pufferben (pH 
7,5, 0,2 $\mathrm{mg} / \mathrm{ml}$ peptid koncentráció) végeztük el. 24 óra reakcióidő után az elegyet félpreparatív RP-HPLC segítségével tisztítottuk.

\section{A peptidek tisztítása RP-HPLC-vel}

$\mathrm{Az}$ éretlen peptideket félpreparatív RP-HPLC-vel tisztítottuk, Shimadzu-Knauer készüléken, a következő oldószerek alkalmazásával: („A” eluens) 0,1\% (V/V\%) TFA, („B” eluens) $80 \%(\mathrm{~V} / \mathrm{V} \%) \mathrm{ACN}, 0,1 \%(\mathrm{~V} / \mathrm{V} \%)$ TFA. A peptidek összetételén alapuló lineáris gradienseket $4 \mathrm{ml} /$ perc áramlási sebesség mellett alkalmaztuk. A csúcsokat $220 \mathrm{~nm}$-en detektáltuk. A peptidek tisztaságát analitikai RP-HPLC-vel ellenőriztük egy Agilent 1200 Series folyadékkromatográf segítségével, ugyanazt az oldószerrendszert használva, mint a tisztítás során. A mozgó fázis kiindulási összetétele 5\% (V/V\%) „B eluens” volt, amelyet 35 perc alatt 40\%-ra (V/V\%) növeltünk $1 \mathrm{ml} /$ perc áramlási sebesség mellett.

A kémiai peptidszintézist és az RP-HPLC-s tisztításokat Dr. Váradi Györgyi, a Szegedi Tudományegyetem, Általános Orvostudományi Kar, Orvosi Vegytani Intézetének munkatársa végezte el.

\subsubsection{Az rNFAP2, az szNFAP2 és peptid fragmenseinek azonosítása}

A rekombináns és szintetikus NFAP2 valamint a szintetikus peptidfragmensek azonosítása és analízise pontos tömegméréssel történt $Q-T O F$ MS (kvadrupól-repülési idő tömegspektrométer, Micromass ${ }^{\circledR}$ Q-TOF, Waters) készülékkel összekapcsolt ultra nagyhatékonyságú folyadékkromatográf (Nano Aquity Ultraperformance Liquid Chromatography System, UPLC, Waters) segítségével BEH130 C18 oszlopon (Waters, oszlophossz: $250 \mathrm{~mm}$, oszlopátmérő: $75 \mu \mathrm{m}$, részecskeméret: 1,7 $\mu \mathrm{m}$ ). A mozgó fázis kiindulási összetétele 3\% (V/V\%) „B eluens” volt (ACN és $0,1 \%(\mathrm{~V} / \mathrm{V} \%)$ hangyasav elegye), amit 40 perc alatt 40\%-ra (V/V\%) növeltünk 350 ml/perc áramlási sebesség mellett (oszloptermosztát hőmérséklete: $40^{\circ} \mathrm{C}$ ). A tömegspektrométert MSE módban alkalmaztuk elektrospray ionizációs forrással, pozitív polaritással. Az adatok kiértékelésére a WATER Biopharmalynx szoftvert (Waters) használtuk.

A tömegspektrometriás méréseket és az adatok kiértékelését Dr. Kele Zoltán, a Szegedi Tudományegyetem, Általános Orvostudományi Kar, Orvosi Vegytani Intézetének munkatársa végezte el. 


\subsubsection{Antifungális érzékenységi tesztek LCM és RPMI 1640 tápoldatban}

\subsubsection{Minimális gátló koncentráció meghatározása LCM tápoldatban}

A natív, rekombináns és szintetikus NFAP2 antifungális hatékonyságát in vitro mikrodilúciós tesztben hasonlítottuk össze. A natív és rekombináns NFAP2-t 9 élesztőgomba izolátummal szemben (4. táblázat), míg a szNFAP2-t C. albicans ATCC 10231, C. krusei CBS 573, C. parapsilosis CBS 604, és S. cerevisiae SZMC 0644 izolátumokkal szemben teszteltük. A natív NFAP2 antifungális hatását 3 fonalasgomba izolátummal szemben is vizsgáltuk.

\section{Inokulumkészítés}

Az egyes élesztőgomba izolátumok sejtszuszpenzióinak elkészítéséhez a Pasteurflaskákban, YEGK táptalajra leoltott telepekből 1-1 kacsnyit 10-10 ml YPD tápoldatot tartalmazó lombikokba oltottunk. A lombikokba oltott élesztőgomba izolátumokat $30{ }^{\circ} \mathrm{C}$-on folyamatos rázatás $(210 \mathrm{rpm})$ mellett 16 órán át növesztettük. Ezután a sejtszámot Bürkerkamra segítségével meghatároztuk, majd a szuszpenzióból $2 \times 10^{5}$ sejt/ml koncentrációjú hígítást készítettünk LCM tápoldatban.

A fonalasgombák esetében a Pasteur-flaskákban, MEA táptalajra masszívan oltott 4 napos tenyészetekre 3-3 ml SP-t mértünk. A telepekről a konídiumokat oltókacs segítségével lemostuk, a szuszpenziót steril vattán átszürtük, majd a Bürker-kamrával történő számolást követően $2 \times 10^{5}$ spóra/ml koncentrációjú hígítást készítettünk LCM tápoldatban.

\section{Mikrodilúciós teszt}

Először a tesztelendő fehérjék törzsoldatából 11 lépcsős felező hígítási sort készítettünk (natív, rekombináns és szintetikus NFAP2-ből 50-0,048 $\mu \mathrm{g} / \mathrm{ml}$ koncentrációban). A proteinek in vitro antifungális hatását 96 lyukú mikrotiterlemezen (96 wells, flat-bottom Tissue Culture Plates, VWR) vizsgáltuk. Minden mintahely $100 \mu 12 \times 10^{5}$ sejt/ml vagy konídium/ml szuszpenziót és $100 \mu \mathrm{l}$ LCM tápoldatban oldott, adott koncentrációjú fehérjét tartalmazott. Növekedési kontrollként $100 \mu$ lápoldatot és $100 \mu 1$ $2 \times 10^{5} \mathrm{sejt} / \mathrm{ml}$ vagy konídium/ml szuszpenzió elegyét használtuk. Steril kontrollként $100 \mu 1$ tápoldatot és $100 \mu \mathrm{l}$ adott koncentrációjú fehérjeoldat keverékét alkalmaztuk. A mikrotiterlapokat $25^{\circ} \mathrm{C}$-on (Aspergillus spp.), $30{ }^{\circ} \mathrm{C}$-on (élesztőgombák), vagy $37{ }^{\circ} \mathrm{C}$-on $(R$. miehei), rázatás nélkül, nedves papírtörlőt tartalmazó műanyag dobozban inkubáltuk. Az egyes mintahelyek fényelnyelését $\left(\mathrm{OD}_{620}\right)$ 0, 24 és 48 óra elteltével, pipettával történő 
összeszuszpendálás és a lemezek $5 \mathrm{mp}$-es rázatását követően SPECTROstar Nano mikrotiterlemez-leolvasó készülékkel (BMG Labtech), a fonalasgombák esetében „well scanning" módban mértük meg. A spektrometriai kalibrációhoz $200 \mu 1$ steril LCM tápoldatot használtunk. Az érzékenységi teszteket három alkalommal ismételtük meg és minden esetben három párhuzamos leoltást alkalmaztunk.

\section{Kiértékelés}

Az egyes fehérjék antifungális hatását a tesztekben történő alkalmazásuk során bekövetkezett növekedésgátlás mértékével jellemeztük. A növekedési kontrollhoz tartozó fényelnyelés mértékét vettük $100 \%$-os növekedésnek minden izolátum esetében, és ehhez viszonyítottuk a fehérjét tartalmazó minta fényelnyelését, ami alapján növekedési százalékot számítottunk. Végül meghatároztuk a MIC (minimal inhibitory concentration, minimális gátló koncentráció) értékeket. MIC-értéknek az alkalmazott protein (vagy későbbiekben peptid) azon legalacsonyabb koncentrációját vettük, amely esetében, az $\mathrm{OD}_{620}$ értékek alapján, 48 óra elteltével sem volt megfigyelhető növekedés (növekedés $\leq 5 \%$ a kezeletlen kontrollhoz képest).

\subsubsection{Az rNFAP2 és az FLK MIC értékének meghatározása RPMI 1640 tápoldatban}

Az rNFAP2 és az FLK (Sigma-Aldrich) Candida izolátumokkal szembeni MIC értékeit a CLSI-M27A3 szabvány előírásainak megfelelően, in vitro mikrodilúciós teszttel határoztuk meg (Clinical and Laboratory Standards Institute, 2008). A tesztekhez szükséges rNFAP2 törzsoldatot bidesztillált vízben, az FLK-t pedig dimetil-szulfoxidban (DMSO) oldottuk fel. A spóraszuszpenziók és hígítások elkészítéséhez RPMI 1640 tápoldatot használtunk. Az rNFAP2 esetében a vizsgált koncentrációtartomány 100-0,39 $\mu \mathrm{g} / \mathrm{ml}$, míg FLK esetében $64-0,0625 \mu \mathrm{g} / \mathrm{ml}$ volt. A szuszpenzióból $2 \times 10^{3} \mathrm{sejt} / \mathrm{ml}$ koncentrációjú hígítást készítettünk. A mikrotiterlemezek összemérése és kiértékelése az előzőekben leírt módon történt, azonban a mikrotiterlapokat ebben az esetben $35^{\circ} \mathrm{C}$-on inkubáltuk.

\subsubsection{Az rNFAP2 és FLK kombináció élesztőgombák növekedésére gyakorolt hatásának vizsgálata}

Az rNFAP2 és FLK közötti szerkölcsönhatást ún. checkerboard titrálással (Eliopoulos és Moellering, 1996) vizsgáltuk, amely során RPMI 1640 tápoldatot alkalmaztunk az rNFAP2 és az FLK hígításainak és a sejtszuszpenziók elkészítése során, a 
CLSI-M27A3 dokumentumban leírtaknak megfelelően (Clinical and Laboratory Standards Institute, 2008). A kombinációs tesztekben C. albicans, C. parapsilosis és C. krusei izolátumok érzékenységét vizsgáltuk. A tesztekhez az rNFAP2 és az FLK törzsoldatából RPMI 1640 tápoldatban 5 lépcsős, felező hígítási sort készítettünk. A mikrotiterlapon elért végső koncentrációtartomány az rNFAP2 esetében 100-6,25 ㅆg/ml volt felező hígításban, az FLK esetében pedig izolátumonként, az egyes MIC értékek alapján változott, felező hígításban $(C$. albicans esetében 1-0,0625 $\mu \mathrm{g} / \mathrm{ml}, C$. parapsilosis esetében 8-0,5 $\mu \mathrm{g} / \mathrm{ml}, C$. krusei esetében 64-4 $\mu \mathrm{g} / \mathrm{ml}$ ). Az elözőekben leírtaknak megfelelöen, ebben az esetben is mintahelyenként $200 \mu$ l végtérfogatban végeztük el a kísérleteket, a korábbiakhoz képest azonban ezúttal egy mintahely $50 \mu 1$ tápoldatban oldott, adott koncentrációjú rNFAP2-t, 50 $\mu 1$ tápoldatban oldott, adott koncentrációjú FLK-t, valamint $100 \mu 12 \times 10^{3} \mathrm{sejt} / \mathrm{ml}$ koncentrációjú sejtszuszpenziót tartalmazott. Az alkalmazott módszernek köszönhetően az egyes mintahelyek a vizsgált hatóanyagok különböző hígításainak más-más kombinációit tartalmazták. A mikrotiterlapokat (96 wells, flat-bottom Tissue Culture Plates, VWR) $35^{\circ} \mathrm{C}$ on, 48 órán keresztül, rázatás nélkül, nedves papírtörlöt tartalmazó müanyag dobozban inkubáltuk.

\section{Kiértékelés}

Ahhoz, hogy a két hatóanyag közötti kölcsönhatás típusát megállapíthassuk, ún. frakcionális gátló koncentráció index (fractional inhibitory concentration index, FICI) értékeket számítottunk az alábbi képlet alapján (Johnson és mtsi., 2004):

$$
\mathrm{FICI}=\mathrm{FIC}_{\mathrm{A}}+\mathrm{FIC}_{\mathrm{B}}=\frac{\mathrm{MIC}_{\mathrm{A}_{\_} \text {kombinációban }}}{\mathrm{MIC}_{\mathrm{A}_{-} \text {_egyedül }}}+\frac{\mathrm{MIC}_{\mathrm{B}_{-} \text {kombinációban }}}{\text { MIC }_{\mathrm{B}_{-} \text {egyedül }}},
$$

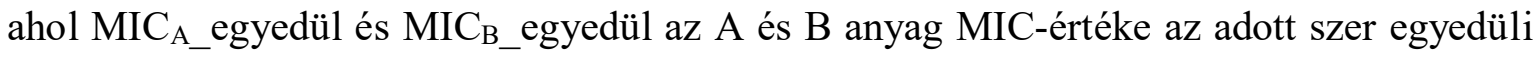

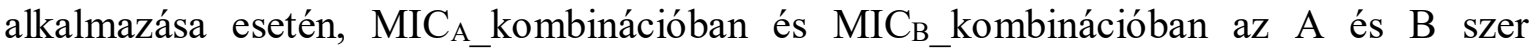
kombinált alkalmazásakor megfigyelt MIC-értéket jelöli, míg a $\mathrm{FIC}_{\mathrm{A}}$ és $\mathrm{FIC}_{\mathrm{B}}$ az $\mathrm{A}$ és $\mathrm{B}$ anyag kombinált alkalmazásakor megfigyelt MIC-értékek és az egyedüli alkalmazáskor megfigyelt MIC-értékek hányadosa. A két szer között fellépő kölcsönhatás szinergizmusnak tekinthető, ha $\mathrm{FICI}<0,5$, antagonizmusnak, ha $\mathrm{FICI}>4$, illetve nincs kölcsönhatás a két hatóanyag között, ha 0,5<FICI $\leq 4$ (Odds, 2003). 


\subsubsection{Az NFAP2 hőstabilitásának vizsgálata}

Az NFAP2 hőstabilitását $S$. cerevisiae-vel szemben mikrodilúciós tesztben vizsgáltuk. Az LCM tápoldatban hígított NFAP2 (0,78-0,049 $\mu \mathrm{g} / \mathrm{ml}$ koncentrációtartomány, felező hígítási sor) minták hőmérsékletét $25^{\circ} \mathrm{C}$-ról folyamatosan $95{ }^{\circ} \mathrm{C}$-ra emeltük, majd 95 ${ }^{\circ} \mathrm{C}$-on 5 percen át inkubáltuk. Szobahőmérsékletre történő lehütés után (30 perc) $100 \mu 1$ adott koncentrációjú kezelt fehérje oldatot az 5.5.7.1. alfejezetben ismertettek alapján elkészített $100 \mu 110^{5} \mathrm{sejt} / \mathrm{ml}$ spóraszuszpenzióval elegyítettünk. A mikrotiterlemezeket (96 wells, flatbottom Tissue Culture Plates, VWR) $30^{\circ} \mathrm{C}$-on, 24 órán át, rázatás nélkül inkubáltuk. A $S$. cerevisiae növekedési képességét az antifungális érzékenységi tesztek esetében (5.5.7.1. alfejezet) leírtak alapján határoztuk meg. A hővel nem kezelt NFAP2-t és a kezeletlen $S$. cerevisiae-t (100 $\mu \mathrm{l}$ LCM tápoldattal $100 \mu 10^{5}$ sejt/ml szuszpenziót elegyítettünk) aktivitási és növekedési kontrollként alkalmaztuk. A teszteket három alkalommal ismételtük meg és minden esetben két párhuzamos leoltást használtunk.

\subsubsection{A hatásmechanizmus tanulmányozása mikroszkópos vizsgálati módszerekkel}

A mikroszkópos vizsgálatok során az NFAP2 antifungális hatását LCM tápoldatban, $30{ }^{\circ} \mathrm{C}$-on történő folyamatos rázatás mellett felnövesztett mid-log fázisú $S$. cerevisiae sejtekkel szemben vizsgáltuk. Az NFAP2 rövid- és hosszútávú antifungális hatásának kimutatásához $10^{5}$ sejt/ml-t (24 órán át tartó inkubáció után megállapított sejtszám) letális $(0,195 \mu \mathrm{g} / \mathrm{ml})$ vagy szubletális $(0,098 \mu \mathrm{g} / \mathrm{ml})$ koncentrációjú NFAP2-vel kiegészített friss LCM tápoldatban rázatva $(210 \mathrm{rpm})$ tenyésztettük 10, 30, 60 percen, illetve 4, 6 és 16 órán át $30{ }^{\circ} \mathrm{C}$-on. Kontrollként NFAP2-mentes LCM tápoldatban felnövesztett sejteket használtuk.

Az NFAP2-vel kezelt és kezeletlen sejtek metabolikus aktivitásának összehasonlítását FUN1 viability stain (Thermo Fisher Scientific) festék segítségével vizsgáltuk. Az apoptótikus és nekrotikus sejtek arányának meghatározását pedig Annexin $V$ FITC (fluorescein isothiocyanate) Apoptosis Detection Kit (Sigma-Aldrich) használatával végeztük el a gyártó utasításait követve. Az NFAP2 plazmamembrán roncsoló aktivitását a membrán impermeábilis, vörösen fluoreszkáló és a kromoszómát festő propídium-jodid (PI) alkalmazásával vizsgáltuk. A sejteket LCM tápoldattal mostuk, majd $5 \mu \mathrm{g} / \mathrm{ml}$ PI-dal 10 percig festettük sötétben és szobahőmérsékleten. Ezután ismét LCM tápoldattal mostuk. A 30 percig, $4{ }^{\circ} \mathrm{C}$-on, $70 \%$-os etanollal (V/V\%) kezelt sejteket pozitív festési kontrollként, míg a kezeletlen sejteket negatív festési kontrollként alkalmaztuk. 
Az összes és Annexin- vagy PI-pozitív sejtek számát Bürker-kamra segítségével határoztuk meg. A mintákat festés után fény- és fluoreszcens mikroszkóppal vizsgáltuk, amihez AxioCam ERc $5 s$ kamerával (Carl Zeiss) felszerelt Axiolab (Carl Zeiss) fluoreszcens mikroszkópot használtunk. A felvételeket a ZEN 2011 (Carl Zeiss) szoftver segítségével készítettük el és értékeltük ki.

Minden vizsgálatot három biológiai párhuzamosban végeztünk el.

\subsubsection{Az NFAP2 funkcionális térképezése}

A teljes hosszúságú antifungális fehérjékből származó peptidfragmensek gombaellenes hatékonyságának vizsgálata lehetővé teszi a lehetséges, antifungálisan aktív fehérjemotívumok azonosítását (Garrigues és mtsi., 2017). Figyelembe véve ezt a módszert, az NFAP2 hat szintetikus peptidfragmensének (7. ábra) és két, vélhetően az antifungális aktivitásáért felelős fragmens (Fragmens-2, Fr-2 és Fragmens-4, Fr-4), kevert aminosavsorrendü változatának gombaellenes hatását in vitro mikrodilúciós tesztben vizsgáltuk annak érdekében, hogy felfedjük a fehérje funkcionálisan aktív helyeit és azt, hogy az antifungális hatás vajon az adott fehérjeszakasz elsődleges szerkezetétől vagy csak a fizikai-kémiai tulajdonságaitól függ-e. A peptidfragmensek növekedésgátló hatását $C$. albicans ATCC 10231, C. krusei CBS 573, C. parapsilosis CBS 604 és S. cerevisiae SZMC 0644 izolátumokkal szemben vizsgáltuk. A tesztelendő szNFAP2 peptidfragmensek törzsoldatából 11 lépcsős felező hígítási sort készítettünk 100-0,098 $\mu \mathrm{g} / \mathrm{ml}$ koncentrációtartományban. A mikrodilúciós tesztek összemérését és kiértékelését az 5.5.7.1 fejezetben leírtak alapján hajtottuk végre.

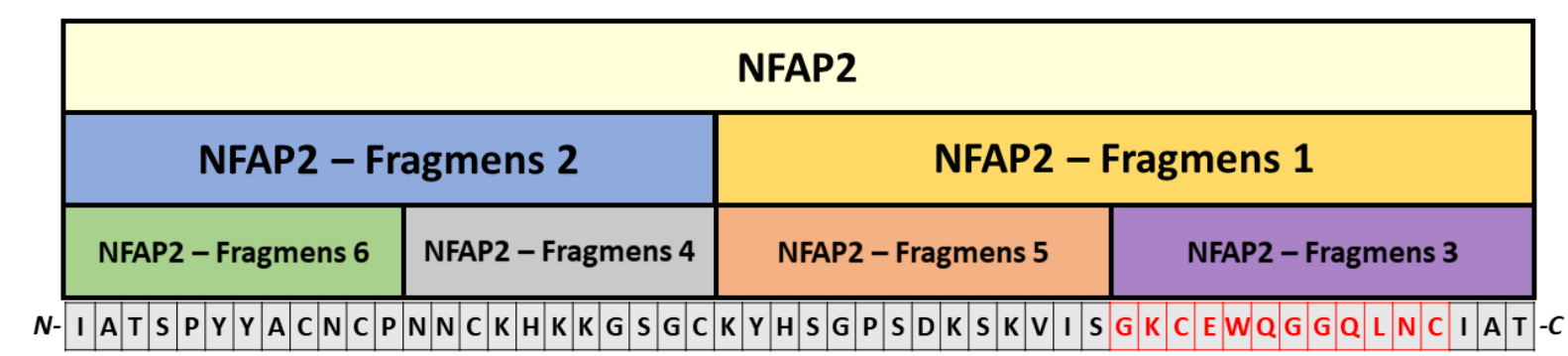

7. ábra. Az érett NFAP2 és szintetizált peptidfragmenseinek szekvenciája. Piros betük jelölik a protein $\gamma$ core motívumát. 
Az NFAP2 funkcionális térképezése során mikroszkópos vizsgálatokat is végeztünk annak igazolására, hogy az antifungális aktivitásért vélhetően felelős NFAP2 peptidfragmensek ugyanolyan módon gátolják-e a gomba növekedését, mint a teljes hosszúságú fehérje. Ezért az NFAP2 és peptidfragmenseinek plazmamembrán roncsoló aktivitását $C$. albicans ATCC 10231 sejtekkel szemben vizsgáltuk, PI-festés alkalmazásával. A mid-log fázisú C. albicans sejteket $\left(2 \times 10^{7} \mathrm{sejt} / \mathrm{ml}\right)$ MIC koncentrációjú NFAP2, Fr-2 és Fr-4 peptidfragmenssel és ezek kevert aminosavsorrendủ változatával LCM tápoldatban rázatva $(210 \mathrm{rpm})$ kezeltünk 10 percig, $30{ }^{\circ} \mathrm{C}$-on. A kezelés után a sejteket az 5.5.8. fejezetben, a $S$. cerevisiae esetében leírtak alapján PI-vel festettük és végül $100 \mu 1$ LCM tápoldatban vettük fel. C. albicans esetében is a pozitív és negatív festési kontrollt az említett fejezetben leírtak szerint készítettük el. A sejtszámok meghatározására és a minták vizsgálatára az 5.5.8. fejezetben leírt eszközöket alkalmaztuk. Az előbbiekben leírt módon megvizsgáltuk a szakirodalmi adatok alapján az antimikrobiális aktivitásban feltételezhetően szerepet játszó, ún. $\gamma$-core motívum (Fragmens-3, Fr-3) antifungális aktivitását is.

\subsubsection{A fehérjék szerkezetvizsgálata (RP-HPLC, ECD, NMR)}

\subsubsection{A fehérjék RP-HPLC-vel történő szerkezetvizsgálata}

A fehérjék feltekeredett szerkezetének (így a valószínüsíthető diszulfid-hidak kialakulásának igazolására) és azok azonosságának megállapításához RP-HPLC méréseket végeztünk Phenomenex Jupiter C18 oszlopon $(250 \times 4,6$ mm, $10 \mu \mathrm{m}$ részecskeméret, $300 \AA$ pórusméret, Phenomenex) Agilent 1100 Series folyadékkromatográf készülékkel (Agilent Technologies). A mozgó fázis kiindulási összetétele 5\% „B eluens” (V/V\%) volt, amelyet 35 perc alatt 40\%-ra (V/V\%) növeltünk $1 \mathrm{ml} /$ perc áramlási sebesség mellett.

Az RP-HPLC méréseket Dr. Váradi Györgyi, a Szegedi Tudományegyetem, Általános Orvostudományi Kar, Orvosi Vegytani Intézetének munkatársa végezte el.

\subsubsection{A fehérjék másodlagos szerkezetének vizsgálata ECD spektroszkópiával}

A $N$. fischeri NRRL 181 által termelt protein másodlagos szerkezetét ECD spektroszkópiával vizsgáltuk. Az ECD mérést Jasco-815 típusú ECD spektrofotométerrel (Jasco) végeztük 25-95 ${ }^{\circ} \mathrm{C}$-on, $195-260 \mathrm{~nm}$ hullámhossz tartományban. A vizsgálat alkalmával a liofilizált fehérjét desztillált vízben oldottuk fel, a fehérjére nézve hozzávetőlegesen $0,1 \mathrm{mg} / \mathrm{ml}$ koncentrációban. A mérés során $0,1 \mathrm{~cm}$ úthosszú kvarc küvettát alkalmaztunk. Termális letekeredés vizsgálatot is végeztünk $25-95{ }^{\circ} \mathrm{C}$ hőmérséklet 
tartományban, amely során a hőmérsékletet Peltier típusú termoelektronikus kontroller (TE Technology) segítségével változtattuk. A vizsgálatok előtt megmértük a tiszta desztillált víz spektrumát és ezt később kivontuk a fehérjét tartalmazó minta spektrumából. A fehérjeminta ECD spektrumát először $25^{\circ} \mathrm{C}$-nál vettük fel $100 \mathrm{~nm} /$ másodperc szkennelési sebesség mellett. Ezt követően a hőmérsékletet folyamatosan emeltük $95{ }^{\circ} \mathrm{C}$-ig a termoelektronikus kontroller segítségével. Ezalatt a $25^{\circ} \mathrm{C}$-on mért spektrumon azonosított extremumokhoz tartozó hullámhosszokon rögzítettük a jelintenzitás hőmérséklet függvényében fokozatosan bekövetkező változásait. A végső hőmérsékleten $\left(95^{\circ} \mathrm{C}\right)$ ismét felvettük a minta ECD spektrumát (195-260 nm tartományban) majd hagytuk, hogy visszahüljön $25^{\circ} \mathrm{C}$-ra. További spektrumfelvételeket készítettünk $25^{\circ} \mathrm{C}$-on egy perccel hütés után, majd 72 óra múlva és még négy héttel később is. Az ellipticitási adatokat mdeg egységekben adtuk meg.

Az RP-HPLC tisztított NFAP2 minták és peptidfragmensek másodlagos szerkezetének vizsgálatát a natív termelö által termelt NFAP2 esetében leírt körülmények között végeztük el, azonban a vizsgálatok során csak 228 nm-en rögzítettük a jelintenzitás hőmérséklet függvényében fokozatosan bekövetkező változásait.

A cirkuláris dikroizmus méréseket és az adatok kiértékelését Dr. Borics Attila, a Magyar Tudományos Akadémia, Szegedi Biológiai Kutatóközpont, Biokémiai Intézetének munkatársa végezte el.

\subsubsection{A fehérjék harmadlagos szerkezetének előzetes vizsgálata NMR spektroszkópiával}

Az NMR mérések során egy 5 mm-es inverz gradiens "txi" szondafejjel felszerelt Bruker Avance II. $500 \mathrm{MHz}$ spektrométert használtunk a spektrumok felvételéhez (Billerica). Az ${ }^{1} \mathrm{H} 90^{\circ}$-os impulzusa tipikusan 9-12 $\mu \mathrm{s}$, a ${ }^{13} \mathrm{C} 90^{\circ}$-os impulzusa $15,7 \mu \mathrm{s}$, és a ${ }^{15} \mathrm{~N} 90^{\circ}$-os impulzusa $37 \mu \mathrm{s}$. A 4,5 mg, $275 \mu$ l acetát pufferben feloldott, jelöletlen szNFAP2 minta ${ }^{13} \mathrm{C}-\mathrm{HSQC}$ (Heteronuclear Single Quantum Coherence) spektrumát a gyártó szabványos "hsqcetgpsi2" impulzus programjának alkalmazásával kaptuk meg $(2024 \times 700$ pont időbeli eloszlásából és a 64 vizsgálatból). A ${ }^{13} \mathrm{C} /{ }^{15} \mathrm{~N}$-jelölt $\mathrm{NFAP2}$ esetében “hsqcctetgpsp” impulzus programot használtuk az időállandó kísérletekhez (Vuister és Bax, 1992), amihez a ${ }^{13} \mathrm{C} /{ }^{15} \mathrm{~N}$-jelölt, 1,1 mg NFAP2-t $275 \mu 1$ acetát pufferben oldottuk fel. A protein HSQC spektrumának felvételéhez $2024 \times 400$ pontot használtunk és a vizsgálatok száma 8 volt minden egyes lépésben. Mindkét fehérje esetében az amid-deuterációs előrehaladást 298 K-en és 4,5 pH-értéken figyeltük. 
A mágneses magrezonancia spektroszkópia méréseket és az adatok kiértékelését Prof. Dr. Batta Gyula, a Debreceni Egyetem, Szerves Kémiai Tanszékének munkatársa végezte el.

\subsubsection{Statisztikai analízis}

A statisztikai analízishez a Microsoft Excel 2010 programot használtuk. A hipotézisvizsgálathoz, illetve a szignifikancia megállapításához kétmintás t-próbát alkalmaztunk, statisztikailag $\mathrm{p}<0,05$ esetén tekintettük szignifikánsnak a különbségeket. 


\section{EREDMÉNYEK ÉS ÉRTÉKELÉSÜK}

\subsection{Az NFAP2 izolálása és azonosítása}

Korábbi, előzetes kísérleteinkben megfigyeltük, hogy a PCMM tápoldatban tenyésztett $N$. fischeri NRRL 181 fermentleve élesztőellenes hatást mutat. Az antifungális hatásért felelős fehérje izolálásához nagyobb mennyiségü tápoldatban megismételtük a tenyésztést és a sejtmentes felülúszót kationcserés oszlopon tisztítottuk. A tisztítása során gyüjtött majd egyesített, antifungálisan aktív frakciókból egy 5,6 kDa méretü fehérje jelenlétét mutattuk ki (8. ábra). Egyéb fehérje, így pl. NFAP, még ezüst-festéssel sem volt kimutatható (8. ábra). Az öt párhuzamos fehérjetermelés NFAP2-kihozatalának átlaga $368 \pm 19 \mu \mathrm{g} / \mathrm{l}$ volt.
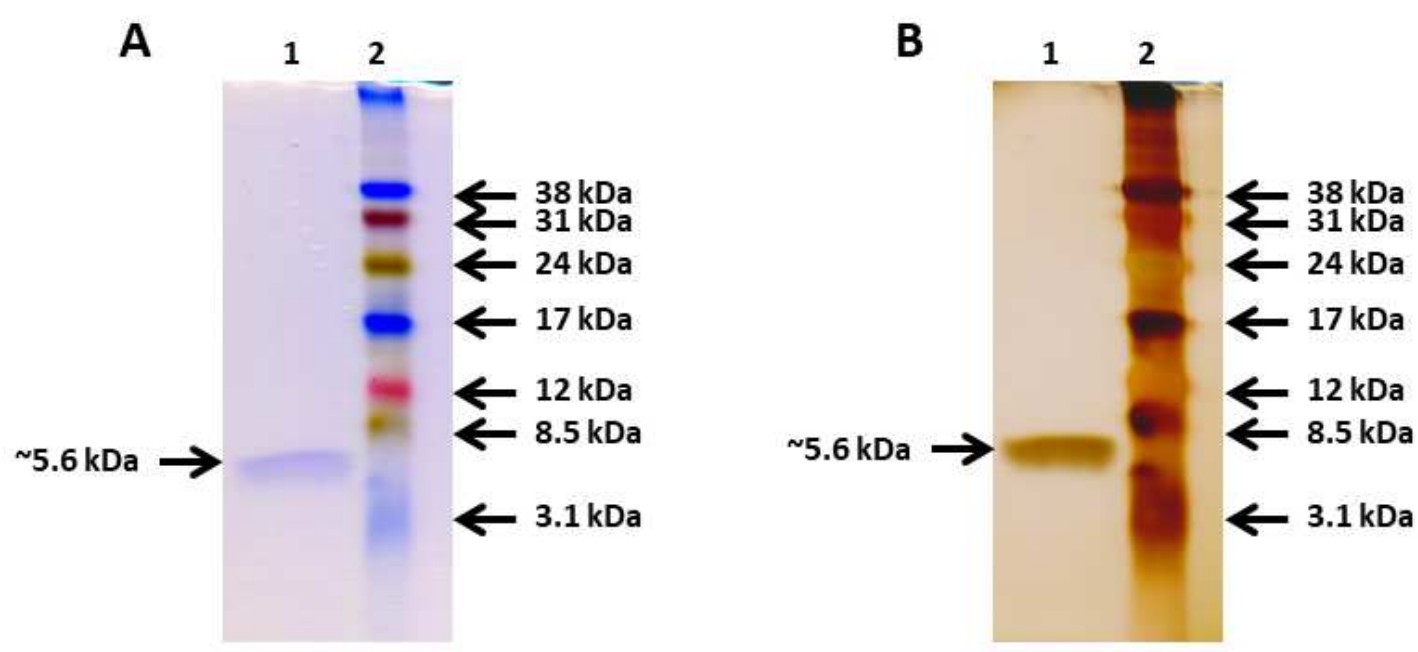

8. ábra. A $N$. fischeri NRRL 181 sejtmentes fermentlevéből származó, a kationcserés oszlopkromatográfiás tisztítás után élesztőellenes aktivitást mutató, egyesített frakciók elektroforetogramja 18\% tris-glicin SDS-PAGE-en Commassie-kék festést (A) és ezüst-festést (B) követően. 1: a fermentlé kationcserés kromatográfiás tisztításából származó, élesztőellenes aktivitást mutató, egyesített frakciókból 1,5 $\mu \mathrm{g}$ tisztított fehérjekivonat, 2: molekulasúly marker (Low-range Amersham Rainbow Marker, GE Healthcare Life Sciences).

A fehérje azonosítását enzimatikus emésztésen alapuló $Q-T O F$ tömegspektrometriás analízissel végeztük el. A móltömeg-mérés alapján az érett, szekretált fehérje pontos monoizotópos molekulatömege 5555,4380 Da (9. ábra), ami azonos a fehérjegélen azonosított sáv méretével. 


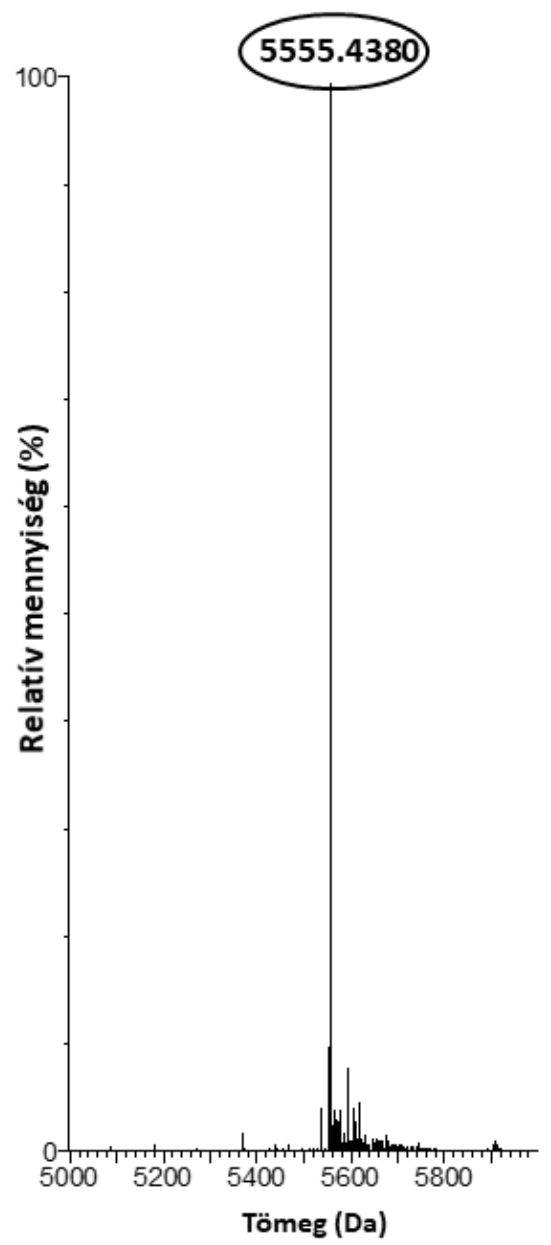

9. ábra. A tisztított NFAP2 ESI-MS monoizotópos tömegspektruma.

Az enzimatikusan emésztett NFAP2 MS analíziséből származó tömegadatok, Mascot search engine szoftver segítségével, adatbázisban történő keresése alapján, a vizsgált fehérje részleges szekvenciáját határoztuk meg, ami egy $N$. fischeri NRRL 181 hipotetikus fehérje IATSPYYACNCPNNCK peptidfragmensének felelt meg (10. ábra). A $N$. fischeri NRRL 181 genom UniProt és NCBI adatbázisokban a IATSPYYACNCPNNCK peptidfragmenssel végzett $B L A S T$-vizsgálat során egy nem-jellemzett, hipotetikus fehérjét azonosítottunk (azonosítószámok: A1DBL3 (UniProt) és XP_001262150.1 (NCBI)). A hipotetikus fehérje N-terminális fragmensének (IATSPYYACNCPNNCKHKKGSGCKYHSGPSDKSKVISG KCEWQGGQLNCIAT) kiszámított monoizotópos molekulatömege $5560.556 \mathrm{Da}$, ami megegyezik az általunk tisztított fehérje mért molekulatömegével abban az esetben, ha a ciszteinek oxidált állapotban vannak, vagyis a diszulfid-hidak kialakultak (10. ábra). Az azonosított 5,6 kDa tömegü fehérjét $N$. fischeri antifungális protein 2-nek (NFAP2) neveztük el, és a kódoló cDNS-szekvenciáját az $E M B L-E B I E N A$ nukleotidszekvencia-adatbázisban az LT160067 azonosítószámmal annotáltuk. 

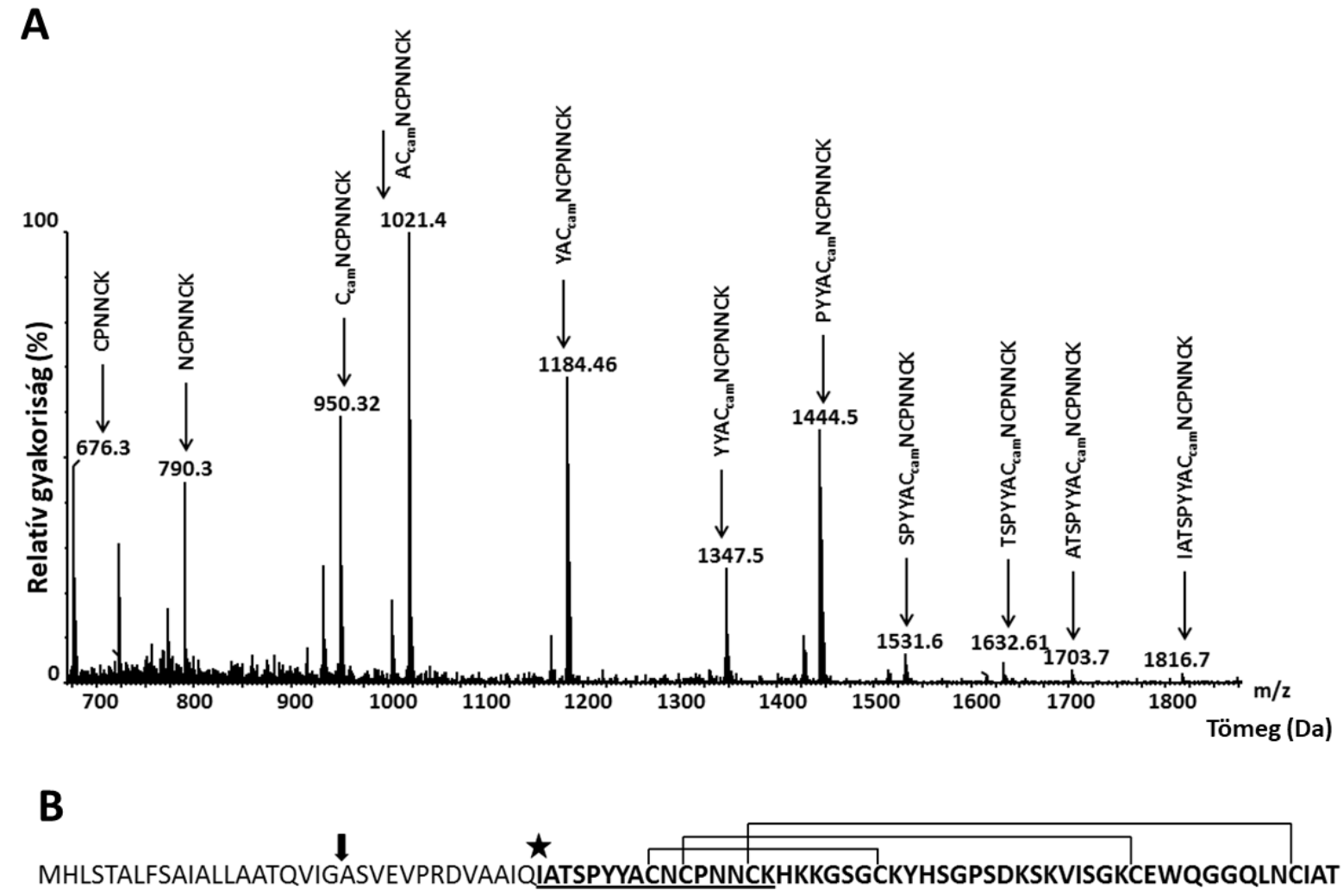

10. ábra. A tisztított NFAP2 N-terminális IATSPYYACNCPNNCK peptidfragmensének MS/MS spektruma (A) és az NFAP2 aminosav-szekvenciája (B). A nyíl a szignálszekvencia lehasadási helyét, a csillag pedig az érett NFAP2 első aminosavát jelöli. Az enzimatikusan emésztett NFAP2 MS analízisével azonosított peptidet aláhúzzásal emeltük ki. A vonallal összekapcsolt ciszteinek az elörejelzett diszulfidhidakat jelölik.

Vizsgálataink eredményeként elmondhatjuk, hogy a $N$. fischeri NRRL 181 az intenzíven tanulmányozott és fonalasgombákkal szemben hatékony NFAP (Kovács és mtsi., 2011; Galgóczy és mtsi., 2013B; Virágh és mtsi., 2014, 2015) mellett egy 5,6kDa tömegü, élesztőellenes fehérje (NFAP2) termelésére is képes. A $N$. fischeri NRRL 181 PCMM tápközegben történő tenyésztését követően az NFAP2, az NFAP esetében is alkalmazott kationcserélő kromatográfiás módszerrel (Virágh és mtsi., 2014) egy lépésben tisztítható volt a felülúszóból. A tisztítás során NFAP jelenléte nem volt megfigyelhető. Ezzel ellentétben a CM tápközegben tenyésztett $N$. fischeri NRRL 181 esetében csak az NFAP volt jelen a felülúszóban (Kovács és mtsi., 2011). Mindezek azt mutatják, hogy a N. fischeri NRRL 181 törzs antifungális protein szekréciós profilja nagymértékben függ az alkalmazott tápközegtől. 


\subsection{In silico vizsgálatok}

Az érett NFAP2 fizikai és kémiai tulajdonságainak meghatározásához, valamint a szignálszekvencia előrejelzéséhez in silico vizsgálatokat végeztünk. Ezek alapján kimutattuk, hogy az NFAP2 egy 86 aminosav hosszúságú preproproteinként expresszálódik, amiről az N-terminális végen elhelyezkedő 21 aminosav hosszúságú extracelluláris szignálszekvencia és az azt következő 13 aminosav az érés során lehasad (10/B ábra). Az NFAP2 érett formája 52 aminosav hosszúságú (10/B ábra), a számított átlagos molekulatömege 5564,3 Da és izoelektromos pontja 9,02. Az NFAP2 hidrofil (átlagos hidrofóbicitás érték; GRAVY $=-0,731$ ) és pozitívan töltött molekula (nettó töltés $\mathrm{pH} 7,0=$ $+5,2$ ) a 0/7/1/1 arányban jelenlévő arginin, lizin, aszparaginsav és glutamin következtében. Az NFAP2 aminosav-szekvenciájának 9., 11., 15., 23., 40. és 49. pozíciójában elhelyezkedő ciszteinek között kialakuló diszulfid-hidak ,abcabc” mintázatba rendeződnek (a kialakult cisztein párok a 9-23., 11-40. és 15-49. aminosav párok között jönnek létre) (10/B ábra).

Összefoglalva, az NFAP2 egy 5,6 kDa tömegü, pozitívan töltött, bázikus molekula, amit három diszulfid-híd stabilizál. Az AFP-hez, a PAF-hoz, a PgAFP-hez, az FPAP-hez, a MAFP1-hez és az NFAP-hoz hasonlóan az NFAP2 is preproprotein formájában expresszálódik, és az érés során lehasadnak a fehérje szekréciójáért és idő előtti aktiváció gátlásáért felelős szekvenciák (Wnendt és mtsi., 1994; Marx és mtsi., 1995; RodriguezMartin és mtsi., 2010; Kovács és mtsi., 2011; Galgóczy és mtsi., 2013; Tu és mtsi., 2016).

\subsection{Az NFAP2 és homológ proteinek filogenetikai analízise}

Az érett NFAP2 aminosav-szekvenciája 11-23\%-os azonosságot mutat a már izolált és jellemzett PAF- és BP-klasztert tartalmazó cgAFP-kel (11. ábra). Jellegzetes aminosavszekvenciamotívumai alapján az NFAP2 jól elkülönül a PAF- és BP-klasztert tartalmazó proteinektől, ami azt mutatja, hogy valószínüleg egy új, eddig nem jellemzett antifungális fehérjecsoporttal van dolgunk. Ennek bizonyítására genomi adatbázisokban NFAP2 homológokat kerestünk, és a PAF- és BP-klasztert tartalmazó, már izolált, illetve feltételezett homológ fehérjék bevonásával filogenetikai analízist hajtottunk végre.

Az NFAP2 homológok keresését a BLAST (Pevsner, 2009) segítségével az NCBI, ExPASy és JGI adatbázisokban végeztük el. A $B L A S T$-vizsgálatok során, a publikált fonalas tömlősgomba genomok között 32 olyan fehérjeszekvenciát találtunk, amelyek nagymértékü hasonlóságot mutatnak az NFAP2-vel (2. számú melléklet). 


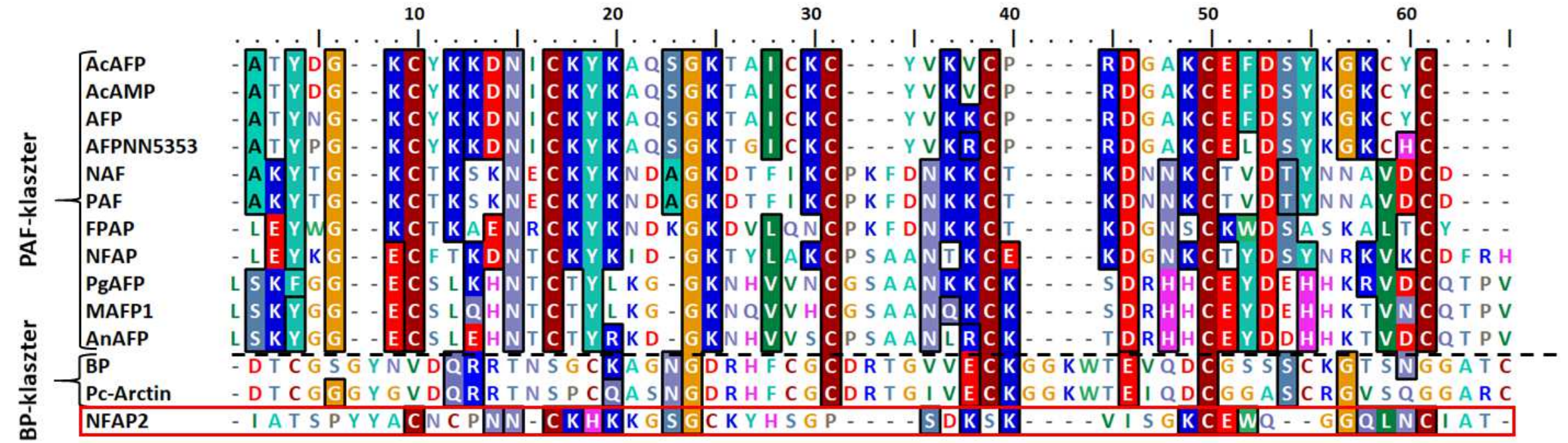

11. ábra. Az eddig izolált cgAFP-k és az NFAP2 aminosav-szekvenciáinak illesztése. AcAFP: Aspergillus clavatus VR1 antifungális ptotein (azonosító: ABR1039), AcAMP: A. clavatus ES1 antimikrobiális protein (azonosító: ABR10398), AFP: Aspergillus giganteus MDH 18894 antifungális protein (azonosító: X60771), AFP A3274 antifungális protein (Binder és mtsi., 2011), AnAFP: A. niger KCTC 2025 antifungális protein, BP: Penicillium brevicompactum DierckX bubble protein (azonosító: P83799), FPAP: Fusarium polyphialidicum SZMC 11042 antifungális protein (azonosító: CAR79015), MAFP1: Monascus pilosus BCRC 38072 antifungális protein 1 (azonosító: AHA86567), NAF: Penicillium nalgiovense BFE 66, 67, 474 antifungális protein (Gaisen, 2000), NFAP: Neosartorya fischeri NRRL 181 antifungális protein (azonosító: CAQ42994), NFAP2: Neosartorya fischeri NRRL 181 antifungális protein2 (azonosító: A0A1D0CRT2), PAF: Penicillium chrysogenum Q176 antifungális protein (azonosító AAA92718), Pc-Arctin: P. chrysogenum A096 antifungális protein (azonosító: CAP96194), PgAFP: P. chrysogenum RP42C antifungális protein (azonosító: ACX54052). MDH: Michigan Department of Health, Michigan, USA; KCTC: Korean Collection for Type Cultures, Daejeon, Koreai Köztársaság; SZMC: Szeged Microbiology Collection, Szeged, Magyarország; BCRC: Bioresource Collection and Research Center, Tajvan, NRRL: Northern Regional Research Laboratory Agricultural Research Service Culture Collection, Peoria, USA. cgAFP: fonala tömlősgomba-eredetű ciszteinben gazdag antifungális protein. 
A homológ fehérjék feltételezett érett formái 35-98\%-os azonosságot mutatnak az NFAP2 aminosav-szekvenciájával (2. számú melléklet). Mind ez idáig egyetlen NFAP2 homológot sem izoláltak vagy írtak le a szakirodalomban, vagyis az NFAP2 az első ilyen izolált fehérje.

Megvizsgáltuk az NFAP2, a PAF- és a BP-klasztert tartalmazó fehérjék filogenetikai kapcsolatait is. Az analízisbe az összes korábban izolált és jellemzett cgAFP-t és azok feltételezett homológjait vontuk be (3. számú melléklet). A filogenetikai analízis eredményeként megállapítottuk, hogy az elemzésbe bevont fehérjék három fő csoportra különíthetők el (12. ábra). Az első csoport tartalmazza a PAF-klasztert hordozó fehérjéket (12. ábra, kék kiemeléssel), a második a BP-klasztert hordozó proteineket (12. ábra, narancssárga kiemeléssel) és a harmadik az NFAP2-t és feltételezett homológjait (12. ábra, zöld kiemeléssel). A három klád statisztikai támogatottsága mérsékelt, ami nem meglepő, tekintettel a fehérjék röviden illeszthető szekvenciáira. Azonban ez a csoportosítás összhangban van több, korábbi filogenetikai elemzés eredményével (Seibold és mtsi., 2011; Galgóczy és mtsi., 2013a; Garrigues és mtsi., 2016). Analízisünk eredményeként megállapíthatjuk, hogy az NFAP2 és feltételezett homológjai (az Acremonium, Alternaria, Aspergillus, Byssothecium, Claviceps, Coniochaeta, Daldinia, Eutypa, Fusarium, Hypoxylon, Karstenula, Massarina, Melanomma, Myriangium, Neosartorya, Niesslia, Penicillium, Paraconiothyrium, Pseudogymnoascus, Pyrenophora, Sordaria és Thozetella nemzetséghez tartozó fajokban található proteinek) a PAF- és BP-klaszter proteinektől filogenetikailag jól elkülönülnek és a cgAFP-k egy új, eddig le nem írt csoportját alkotják.

Érdemes megjegyezni, hogy a $N$. fischeri NRRL 181 genomjában egy feltételezett BP-klasztert tartalmazó fehérjét kódoló gén is azonosítható, amit N. fischeri "bubble protein"-nek neveztünk el (NFBP, azonosító szám: A1DKX1). A SignalP1 4.1 szerver (Petersen és mtsi., 2011) segítségével elvégzett in silico vizsgálat eredményeként megállapítottuk, hogy az NFBP is egy szekretált protein. Mindezek alapján feltételezhetjük, hogy a $N$. fischeri NRRL 181 különböző evolúciós eredetű és valószínűleg eltérő antifungális spektrummal rendelkező extracelluláris antifungális fehérjék termelésére képes, amik fontos szerepet játszhatnak más gombákkal szemben, az azonos élőhelyért folytatott küzdelemben (Kovács, 2014). 


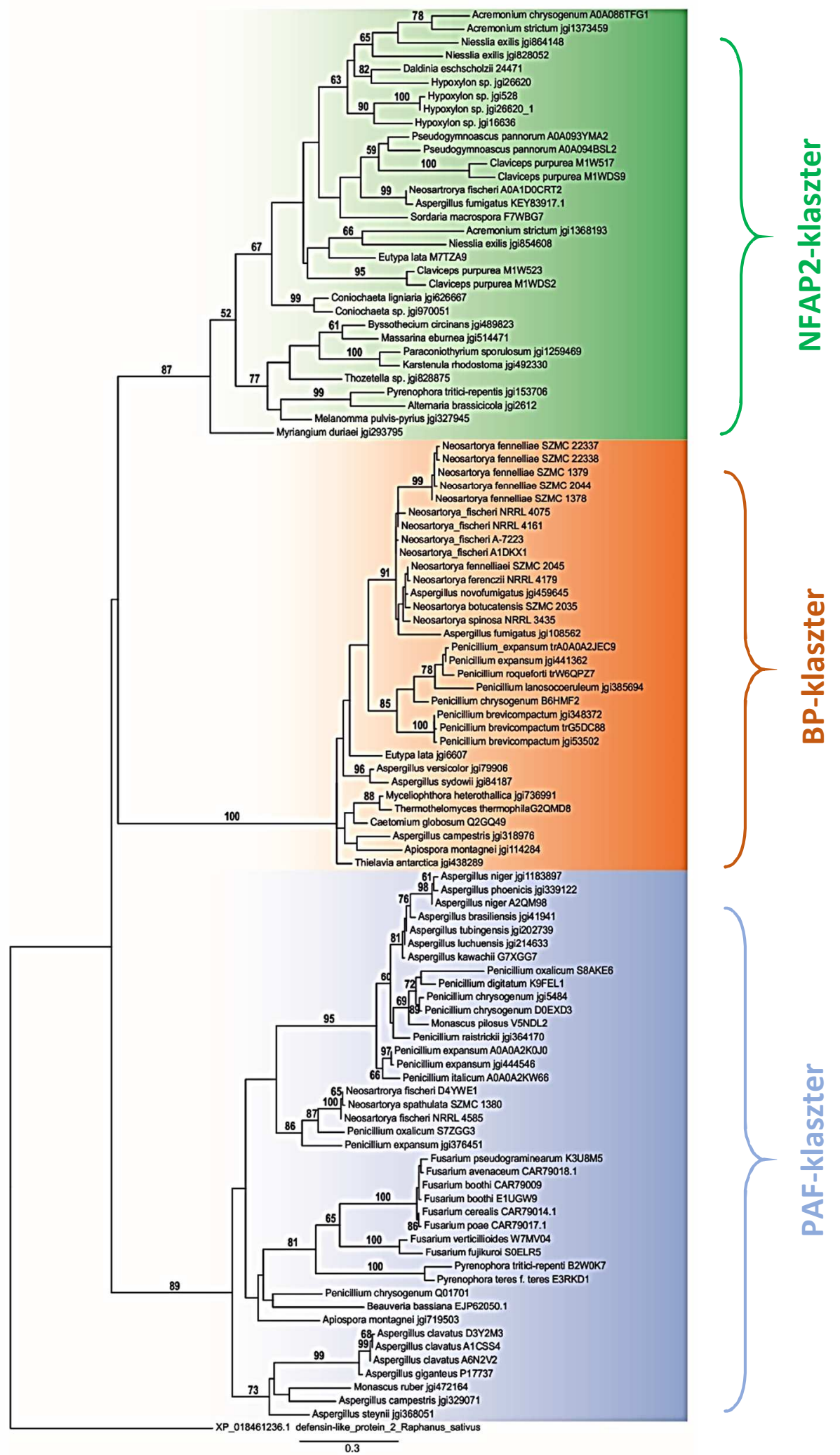

12. ábra. Az izolált és feltételezett $\operatorname{cgAFP-k}$ aminosav-szekvenciáján alapuló filogenetikai fa. Kék kiemelés: a PAF-klaszter proteinek, narancssárga kiemelés: a BP-klaszter proteinek és a zöld kiemelés: az NFAP2 és feltételezett homológjai. A fajnév után a fehérje azonosítószámát (3. számú melléklet) vagy a termelő izolátum törzsgyüjteményi azonosítóját tüntettük fel (abban az esetben, ha a fehérje szekvenciája adatbázisokban nem elérhető). cgAFP: fonalas tömlősgomba-eredetű ciszteinben gazdag antifungális protein. 


\subsection{Az NFAP2 antifungális hatásmechanizmusának tanulmányozása}

\subsubsection{Antifungális érzékenységi tesztek}

Az NFAP2 antifungális hatékonyságát LCM tápközegben, in vitro mikrodilúciós tesztben vizsgáltuk. A vizsgálatba kilenc élesztő- és három fonalasgomba izolátumot vontunk be (4. táblázat). Az NFAP2 az alkalmazott koncentrációtartományban (50-0,048 $\mu \mathrm{g} / \mathrm{ml}$ ) hatékonyan gátolta az élesztőgombák növekedését dózisfüggő módon, azonban a fonalasgombák vele szemben rezisztensnek bizonyultak (7. táblázat). 24 óra inkubációt követően az NFAP2 élesztőkkel szemben megfigyelt MIC értékei a 0,195-1,56 $\mu \mathrm{g} / \mathrm{ml}$ tartományba estek. A kísérlet során a $S$. cerevisiae mutatkozott a legérzékenyebbnek, a legnagyobb MIC értéket pedig a C. krusei esetében határoztuk meg.

7. táblázat. Az NFAP2 minimális gátló koncentrációja LCM tápoldatban 24 órán (Candida spp.) és 48 órán (Aspregillus spp., Rhizomucor miehei) át tartó, $25{ }^{\circ} \mathrm{C}$ (Aspergillus spp.), $30{ }^{\circ} \mathrm{C}$ (Candida spp.) és $37^{\circ} \mathrm{C}$-on (R. miehei) történő inkubációt követően.

\begin{tabular}{lc}
\hline Izolátum & MIC $(\boldsymbol{\mu g} / \mathrm{ml})$ \\
\hline \multicolumn{2}{c}{ Élesztögombák } \\
\hline Candida albicans ATCC 10231 & 0,78 \\
Candida glabrata CBS 138 & 0,39 \\
Candida guilliermondii CBS 566 & 0,39 \\
Candida krusei CBS 573 & 1,56 \\
Candida lusitaniae CBS 6936 & 0,78 \\
Candida parapsilosis CBS 604 & 0,39 \\
Candida tropicalis CBS 94 & 0,39 \\
Saccharomyces cerevisiae SZMC 0644 & 0,195 \\
Schizosaccharomyces pombe SZMC 0142 & 0,39 \\
\hline \multicolumn{2}{c}{ Fonalasgombák } \\
\hline Aspergillus nidulans FGSC A4 \\
Aspergillus niger SZMC 601 \\
Rhizomucor miehei CBS 360.92 & $>50$ \\
\hline
\end{tabular}

MIC: minimális gátló koncentráció

Korábbi tanulmányokban már kimutatták, hogy a PAF- és BP-klasztert hordozó fehérjék eltérő antifungális spektrummal rendelkeznek (Marx, 2004; Galgóczy és mtsi., 2010; Seibold és mtsi., 2011; Chen és mtsi., 2013). A PAF-klaszter tagjai a fonalasgombákkal szemben már kis koncentrációban hatékony antifungális aktivitást mutatnak, azonban élesztőkkel szemben egyáltalán nem (Marx, 2004; Galgóczy és mtsi., 
2010) vagy csak nagy koncentrációban alkalmazva (Lee és mtsi., 1999; Seibold mtsi., 2011; Galgóczy és mtsi., 2013a) aktívak. A BP-klaszter tagjai mérsékelt antifungális hatással bírnak fonalas- és élesztőgombákkal szemben egyaránt (Seibold és mtsi., 2011; Chen és mtsi., 2013).

\subsubsection{Az NFAP2 hatásmechanizmusának mikroszkópos vizsgálata}

Az NFAP2 antifungális hatását mid-log fázisú $S$. cerevisiae SZMC 0644 sejtekkel szemben mikroszkópos technikákkal vizsgáltuk, 24 óra inkubáció után, a fehérje letális $(0,195 \mu \mathrm{g} / \mathrm{ml})$ és szubletális $(0,098 \mu \mathrm{g} / \mathrm{ml})$ koncentrációban történő alkalmazásával. Az élesztősejtekben az antifungális protein jelenlétében végbemenő fiziológiai változásokat FUN1 és PI festéssel (Thermo Fisher Scientific) és Annexin V-FITC Apoptosis Detection Kit-tel (Sigma-Aldrich) követtük nyomon.

Az NFAP2 a $S$. cerevisiae SZMC 0644 metabolikus aktivitására kifejtett hatását FUN-1 fluoreszcens festékkel vizsgáltuk a fehérje szubletális koncentrációban történő alkalmazása során. Ez a festék passzív diffúzióval képes bejutni a citoplazmába és ott a metabolikusan aktív vakuólumokat pirosra, míg a metabolikusan inaktívakat zöldre festeni. A S. cerevisiae SZMC 0644 metabolikus aktivitásában, a piros és zöld vakuólumok aránya alapján, a kezelt és kezeletlen minták között nem volt megfigyelhető változás még 16 órás NFAP2 kezelést követően sem (nem közölt adatok).

A S. cerevisiae SZMC 0644 törzs esetében a szubletális koncentrációban alkalmazott NFAP2 hatására bekövetkező apoptótikus és nekrotikus eseményeket Annexin V-FITC Apoptosis Detection Kit-tel vizsgáltuk. Ez a kit két festéket tartalmaz: a fluoreszceinizotiocianát (FITC) kromofórral konjugáltatott Annexin V-öt és a PI-t. Az Annexin V-FITC az apoptózis korai szakaszában a sejtmembrán intracelluláris oldaláról az extracelluláris felszínére transzlokálódott foszfatidil-szerinhez kötődik és a sejtet zöldre festi. A PI nem jut át az intakt sejtmembránon, azonban a membrán integritásának megszűnése után bejut a sejtbe és a DNS-hez kötődve azokat pirosra festi. Vizsgálatunk során a szubletális koncentrációjú NFAP2-vel kezelt és kezeletlen mintákban nem volt szignifikáns különbség a zölden festődött sejtek aránya (az összes sejtszám kb. 1\%-a) között még 16 óra inkubáció után sem. Ehhez hasonlóan a rövid idejü (10, 30 és 60 perces) NFAP2 kezelést követően a PI-dal festődött sejtek aránya (az összes sejtszám kb. 1\%-a) is megegyezett a kezelt és a kezeletlen mintákban. Tizenhat óra inkubációt követően azonban, a kontrollhoz képest háromszor több piros festődést mutató sejt volt megfigyelhető a fehérje-kezelt mintában, ami 
statisztikailag szignifikáns különbséget jelent $(\mathrm{p}=0,00004)$. Ezek a megfigyelések arra engedtek következtetni, hogy az NFAP2 nem változtatja meg az élő sejtek metabolikus aktivitását és apoptózist sem indukál, viszont plazmamembrán roncsoló hatása lehet.

Az NFAP2 plazmamembrán roncsoló hatását PI festés alkalmazásával vizsgáltuk a fehérje szubletális és letális koncentrációban történő használata során. Hat órán át tartó inkubációt követően, az eddig tapasztalt megfigyelésekhez hasonlóan, a pirosan festődött sejtek száma megegyezett a kezeletlen és a szubletális koncentrációjú NFAP2-vel kezelt mintákban. Ugyanakkor, 16 óra inkubációt követően a kezeletlen kontrollban a teljes sejtszám 6\%-a, míg az NFAP2-kezelt mintában a sejtek 18\%-a volt PI-pozitív (13/A és C ábrák). A letális koncentrációjú NFAP2 esetében már 10 perces inkubációt követően szignifikáns különbség volt megfigyelhető a kontroll és a kezelt mintákban jelenlévő piros fluoreszcenciát mutató élesztősejtek száma között (13/B és C ábrák). Tizenhat óra elteltével pedig a kezelt mintában már nem volt megfigyelhető életképes sejt (13/C ábra). Eredményeink azt jelzik, hogy az NFAP2 antifungális hatásmechanizmusának hátterében plazmamembrán roncsoló hatás állhat, ami dózis és időfüggő.

Összefoglalva elmondhatjuk, hogy a cgAFP-khez hasonlóan az NFAP2 is dózisfüggő módon fejtette ki antifungális hatását az érzékeny gombaizolátumokkal szemben (Kaiserer és mtsi., 2003; Marx, 2004). Szubletális koncentrációban alkalmazva az NFAP2 növekedésgátló hatású volt, azonban magasabb koncentrációban ez a hatás már fungicid jellegüvé vált.

A szakirodalomban leírt cgAFP-k fajspecifikus hatást mutatnak és antifungális spektrumuk nagyon eltérő lehet (Marx, 2004). Ezek a fehérjék elsősorban mezőgazdasági és egészségügyi szempontból jelentős patogén fonalasgombákkal szemben mutatnak növekedésgátló hatást (Lacadena és mtsi., 1995; Lee és mtsi., 1999; Geisen, 2000; Theis és mtsi., 2003; Kaiserer és mtsi., 2003; Marx, 2004; Moreno és mtsi., 2003, 2006; Meyer, 2008; Barna és mtsi., 2008; Galgóczy és mtsi., 2005, 2007, 2008; Kovács és mtsi., 2011; Virágh és mtsi., 2014). Az AnAFP, az FPAP és a BP viszonylag magas koncentrációtartományban fejtettek ki antifungális hatást Candida fajokkal és $S$. cerevisiae-vel szemben (Lee és mtsi., 1999; Seibold és mtsi., 2011; Galgóczy és mtsi, 2013). Kísérleteink során már az alacsony koncentrációban alkalmazott NFAP2 is teljes növekedésgátlást eredményezett a vizsgált, súlyos bőr-, nyálkahártya- vagy szisztémás fertőzés kialakulásáért felelős $C$. albicans és más, NAC klinikai izolátumok esetében, ugyanakkor az NFAP-val ellentétben, a 
fonalasgombák rezisztensnek bizonyultak a fehérjével szemben (Kovács és mtsi., 2011) (7. táblázat).
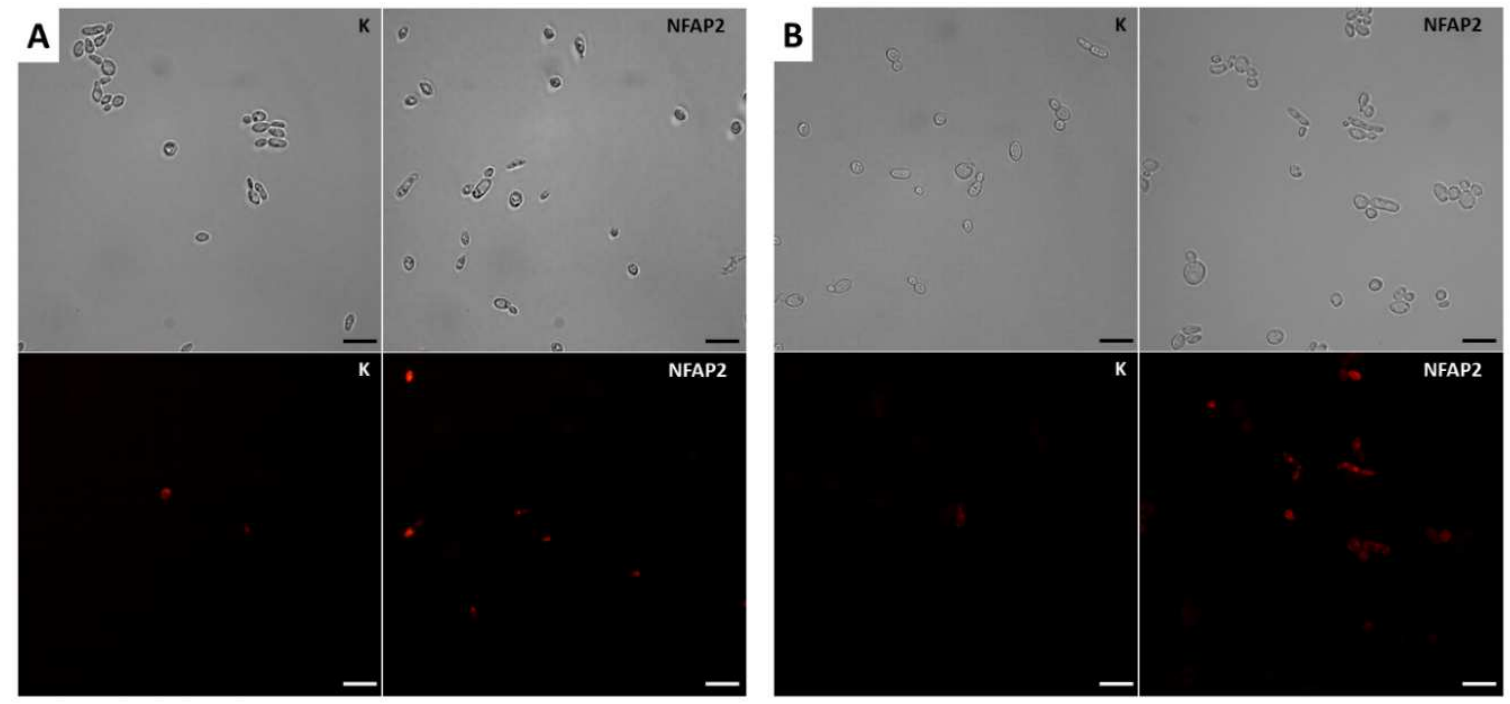

C

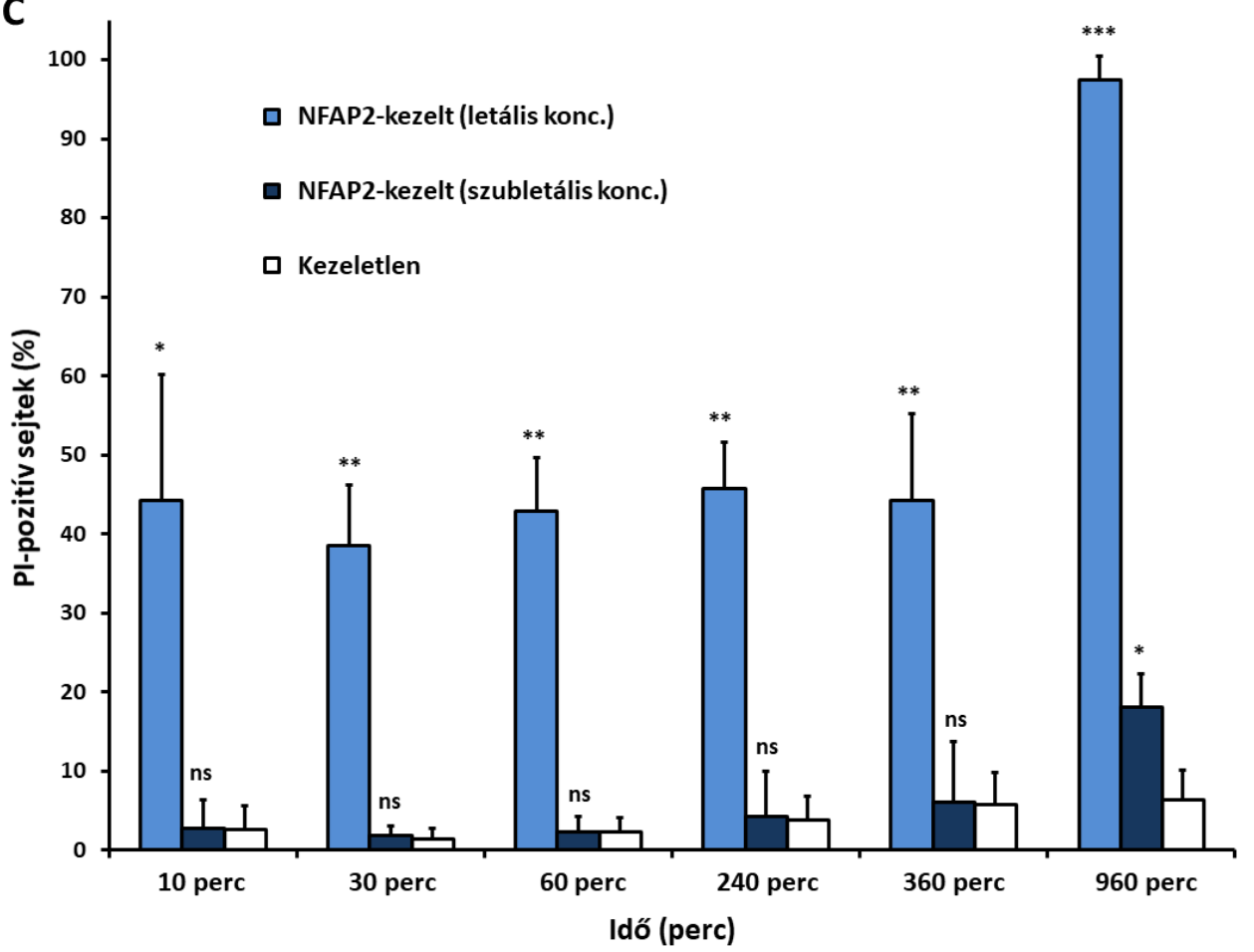

13. ábra. A S. cerevisiae SZMC 0644 PI-vel történő festése 16 órán át tartó, $30{ }^{\circ} \mathrm{C}$-on történő, szubletális koncentrációban $(0,098 \mu \mathrm{g} / \mathrm{ml})$ (A) és 10 perces, $30^{\circ} \mathrm{C}$-on történő, letális koncentrációban $(0,195 \mu \mathrm{g} / \mathrm{ml})$ alkalmazott NFAP2-kezelés után (B). A piros festődés membránkárosodást jelez. K: kezeletlen kontroll, NFAP2: NFAP2-kezelt sejtek. Méretskála: $20 \mu \mathrm{m}$. A PI-pozitív $\boldsymbol{S}$. cerevisiae sejtek aránya szubletális és letális koncentrációban alkalmazott NFAP2-kezelt és kezeletlen mintákban eltérő időtartamú, $30{ }^{\circ} \mathrm{C}$-on történő inkubációt követően (C). A szignifikancia-értékeket (p-érték) a kezeletlen kontrollokhoz viszonyítva határoztuk meg. ${ }^{* * *} \mathrm{p}<0,0001,{ }^{* *} \mathrm{p}<0,005,{ }^{*} \mathrm{p}<0,05$, ns: nincs szignifikáns különbség. 
A mikroszkópos vizsgálatainkat a fonalasgombákkal szemben hatékony NFAP kapcsán a szakirodalomban leírt hatásmechanizmussal összevetve elmondhatjuk, hogy a rövid időtartamú NFAP-kezelés csökkent metabolikus aktivitást és apoptózis indukciót vált ki az arra érzékeny $A$. nidulans-ban, a plazmamembránt viszont nem károsítja (Virágh és mtsi., 2015). Ezzel szemben az élesztőgomba-ellenes NFAP2 rövid időtartamon belül nem indukál apoptózist és nem okoz változást a metabolikus aktivitásban, viszont roncsolja a plazmamembránt, ami a hatásmechanizmusának fö eleme lehet. Ez utóbbi igazolására és a

pontos hatásmechanizmus feltárására azonban további kísérletek szükségesek. A szakirodalomban számos növényi és humán kationos antimikrobiális peptid esetében már leírtak C. albicans és nem-albicans sejteken kifejtett plazmamembrán roncsoló aktivitást (Nawrot és mtsi., 2013; Swidergall és Ernst, 2014). Továbbá megfigyelték, hogy az antimikrobiális proteinek plazmamembrán roncsoló képessége szorosan összefügg a fehérjében jelenlévő arginin és lizin aminosavak számával, amik a molekulát pozitívan töltötté teszik (Lee és Lee 2015; Tam és mtsi., 2015). Ezek alapján feltételezhetjük, hogy az NFAP2 plazmamembrán roncsoló hatásáért is a hét lizin aminosav jelenléte miatt kialakuló nagymértékű pozitív töltés (nettó töltés $\mathrm{pH} 7,0=+5,2$ ) tehető felelőssé.

\subsection{Az NFAP2 hőstabilitásának és szerkezetének vizsgálata}

A diszulfid-hidakat tartalmazó, feltételezett kompakt szerkezete következtében az NFAP2 is nagymértékủ stabilitást mutathat tág hőmérsékleti tartományon belül az NFAPhoz és egyéb cgAFP-khez hasonlóan (Kovács és mtsi., 2011). Az LCM-ben hígított NFAP2 oldat $(0,78-0,05 \mu \mathrm{g} / \mathrm{ml}$ koncentrációtartományban, felező hígítási sorban) hőmérsékletét 25 ${ }^{\circ} \mathrm{C}$-ról folyamatosan $95{ }^{\circ} \mathrm{C}$-ra emeltük, majd $95{ }^{\circ} \mathrm{C}$-on 5 percen át inkubáltuk. Az NFAP2 höstabilitását ezután $S$. cerevisiae-vel szemben mikrodilúciós tesztben vizsgáltuk. A hőkezelés után az NFAP2 megörizte a $S$. cerevisiae-vel szemben mutatott antifungális aktivitását, habár a MIC érték egy felező hígítási léptékkel 0,195 $\mu \mathrm{g} / \mathrm{ml}-$-ről 0,39 $\mu \mathrm{g} / \mathrm{ml}-\mathrm{re}$ növekedett.

Az NFAP2 diszulfid-hidakkal stabilizált, kompakt szerkezetét RP-HPLC analízissel, míg másodlagos szerkezeti elemeit és a diszulfid-hidak által biztosított hőstabil tulajdonságot ECD spektroszkópiával és az ezzel nyomon követhető termális letekeredési vizsgálatokkal bizonyítottuk. Az MS-adatok alapján, a ciszteinek oxidált állapotban vannak jelen a molekulában, ami a diszulfid-hidak kialakulását és így egy kompakt harmadlagos szerkezet létrejöttét feltételezi. Az RP-HPLC képes a peptidek és fehérjék retenciós 
viselkedése és konformációja közötti korreláció vizsgálatára. Az említett képesség, valamint a PAF feltekeredésére vonatkozó korábbi tapasztalatok alapján (Váradi és mtsi., 2013), az NFAP2 diszulfid-kötésekkel stabilizált kompakt harmadlagos szerkezete bizonyíthatóvá vált. A 14. ábra a feltekeredett NFAP2 és a PAF RP-HPLC elúciós profilját mutatja, ugyanazon körülmények között.
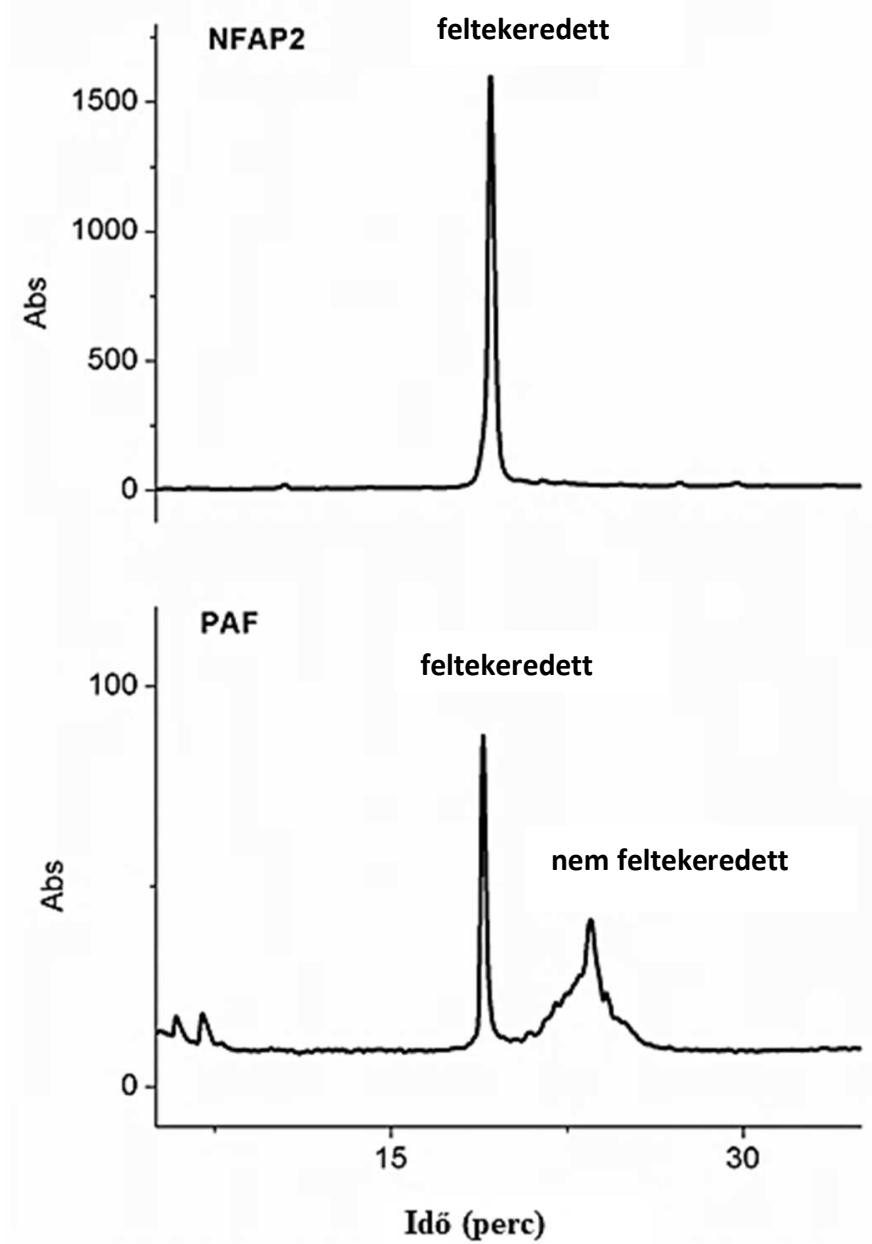

14. ábra. Az NFAP2 RP-HPLC kromatogramja és annak összehasonlítása a feltekeredett és nem feltekeredett PAF-éval.

Az NFAP2 és a PAF szerkezeti hasonlóságokat mutatnak a kationos jellegük és aminosav-szekvenciájuk hosszával kapcsolatban, továbbá mindkét fehérjét három diszulfidhíd stabilizálja. A PAF esetében már bebizonyították, hogy a ciszteinek között kialakult kötések „abcabc” mintázatot mutatnak és a természetes állapotú feltekeredett PAF-nak az RP-HPLC-s vizsgálat során sokkal rövidebb a retenciós ideje, mint bármely más, nem természetes diszulfid-híd mintázattal rendelkező változatáé (Batta és mtsi., 2009; Váradi és mtsi., 2013). Figyelembe véve, hogy a természetes módon feltekeredett PAF-hoz hasonlóan 
az NFAP2 is hamar lemosódik a fordított fázisú oszlopról, a kompakt PAF-éval megegyező diszulfid-híd mintázat (,abcabc”) valószínűsíthető, mint ahogy azt az in silico vizsgálatok során is előre jeleztük (10/B ábra).

Az NFAP2 $25{ }^{\circ} \mathrm{C}$-on mért ECD spektruma 200 nm-en és 228 nm-en két maximummal, $212 \mathrm{~nm}$-en pedig egy alacsony intenzitású minimummal rendelkezik (15/A ábra, fekete görbe). Ezek a tulajdonságok megegyeznek a PAF és más, diszulfid-hidakkal stabilizált, $\beta$-szerkezetű fehérjék ECD spektrumával (Lees és mtsi., 2006; Fizil és mtsi., 2015). A 200 nm-en mérhető maximum a $\beta$-redőzött szerkezet és a diszulfid-hidak jelenlétére utal, a 228 nm-es maximum leginkább a ciszteinek közötti kötéseknek tulajdonítható, míg a $212 \mathrm{~nm}$-en megfigyelt minimum ismét a $\beta$-konformációt jelöli. Magas hőmérsékleten a 228 nm-nél rögzített intenzív pozitív csúcs eltünése vagy a konformáció megváltozását (Hider és mtsi., 1988) vagy a diszulfid-hidak UV-fény okozta felszakadását jelzi. Korábbi tanulmányok bizonyították, hogy az aromás aminosavak UV által történő gerjesztése elektron vagy hidrogénatom vesztéssel járhat, ami a diszulfid-kötéseket redukálhatja (Neves-Petersen és mtsi., 2002). Az NFAP2 hőstabilitását a termális letekeredési görbék mutatják (15/B ábra), amik alapján a protein feltekeredett szerkezete 70 ${ }^{\circ} \mathrm{C}$-ig változatlan marad, azonban az ezután következő termális denaturáció irreverzibilis. Az NFAP2 oldat $25{ }^{\circ} \mathrm{C}$-ra történő visszahütése után a protein mérsékelt szerkezeti visszarendeződése történik, azonban ez a visszarendeződés még négy héttel a hőkezelés után sem teljes.

A vizsgálatok során nyert eredmények alapján elmondhatjuk, hogy az NFAP2 az NFAP-hoz hasonlóan (Kovács és mtsi., 2011) hőstabil tulajdonsággal rendelkezik a feltekeredett és diszulfid-kötésekkel stabilizált harmadlagos szerkezetének köszönhetően. Ez a szerkezet a cgAFP-k csoportjára általánosan jellemző, és az AFP (Campos-Olivas és mtsi., 1995; Lacadena és mtsi., 1995), a PAF (Batta és mtsi., 2009), illetve a BP (Olsen és mtsi., 2004) esetében már kísérletesen is bizonyított.

\subsection{Az NFAP2 heterológ expressziója}

Eddigi eredményeink alapján a $N$. fischeri NRRL 181 által termelt NFAP2 ígéretes jelölt lehet új, fehérjén alapuló antifungális stratégiák kifejlesztésére a gyógyászatban, mivel hatékonyan gátolja a gombafertőzések nagy hányadáért felelős Candida fajok vizsgált izolátumainak növekedését. Az NFAP2 szerkezetének pontos meghatározása, hatásmechanizmusának és toxicitásának megismerése, továbbá az antifungális aktivitás és 
szerkezet közötti kapcsolat feltárása elengedhetetlen a klinikumban történő felhasználáshoz. Mivel a $N$. fischeri NRRL 181 csak kis mennyiségben választja ki az NFAP2-t a fermentlébe, így a további gyakorlati célú vizsgálatához szükségessé vált a fehérje nagy mennyiségben történő előállítása egy biztonságosan alkalmazható és nagy fehérjekihozatalt biztosító heterológ expressziós rendszer segítségével.
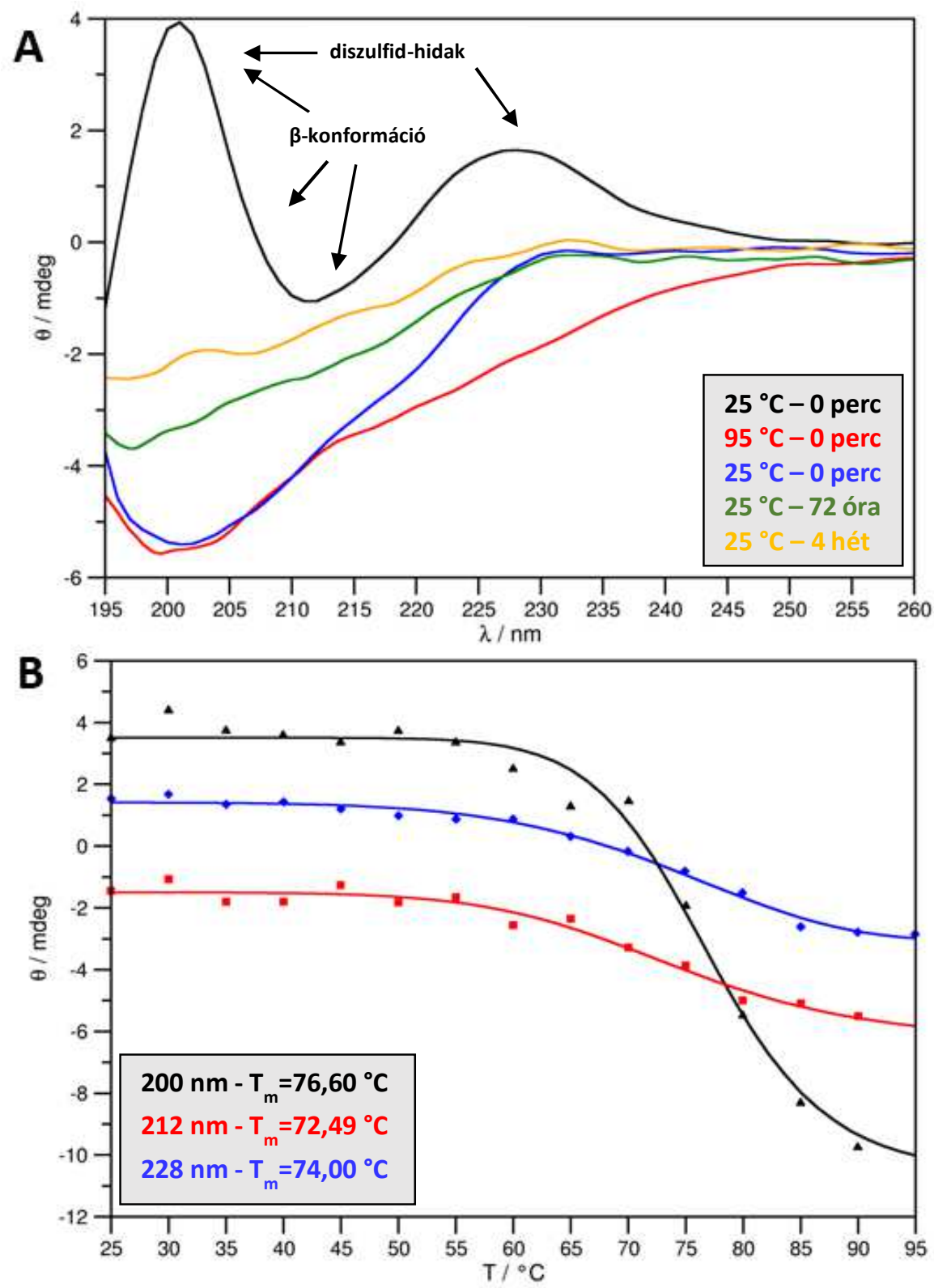

15. ábra. Az NFAP2 $25^{\circ} \mathrm{C}$-on (fekete), $95^{\circ} \mathrm{C}$-on (piros) és a hökezelést követően, $25^{\circ} \mathrm{C}$-on, közvetlenül (kék), 72 óra (zöld) és 4 hét (citromsárga) után rögzített ECD spektruma (A). Az NFAP2 200 nm-en (fekete, $R^{2}=0,9899, T_{m}=76,60{ }^{\circ} \mathrm{C}$ ), 212 nm-en (piros, $R^{2}=0,9770, T_{m}=72,49{ }^{\circ} \mathrm{C}$ ) és 228 nm-en (kék, $R^{2}=0,9910, T_{m}=74,00{ }^{\circ} \mathrm{C}$ ) mért termális letekeredési görbéi (B). 


\subsubsection{Az NFAP2 heterológ termelésére alkalmas expressziós vektor létrehozása és bejuttatása a $P$. chrysogenum $\Delta$ paf törzsbe}

A paf proszekvenciával és a paf 3'-UTR-rel részben átfedő nfap2 cDNS-ét a pUC57 plazmid EcoRV restrikciós helyére beágyazott szintetikus konstrukcióból amplifikáltuk. Az így felszaporított 273 bp amplikont a pGEM-T vektorba klónoztuk. A paf részleges 5'- és 3'-UTR határolt, a paf preproszekvenciához fúzionált nfap2 cDNS pGEM-Tnfap2 vektorból történő felszaporítását követően a pSK275paf plazmidba klónoztuk. Az így elkészült pSK275nfap2 expressziós vektor az 1280 bp paf 5'- és 373 bp 3'-UTR határolt, a paf gén preproszekvenciájával fúzionált nfap 2 cDNS-t tartalmazta (1. számú melléklet). Az nfap2t hordozó vektor $P$. chrysogenum $\Delta p a f$ sejtekbe történő bejuttatását követően a nagy mennyiségü rNFAP2 termelésére legalkalmasabb transzformáns kiválasztásához 10 klónt PCMM tápoldatban növesztettünk. A vektoron található paf gén szignálszekvencia lehetővé teszi a fehérje extracelluláris szekrécióját és ezáltal a fermentléből történő kimutatását. A legalkalmasabb termelő kiválasztásához a 10 klón felülúszójából 48, 72 és 96 óra után vett minták fehérjetartalmát, centrifugálást követően, 18\%-os poliakrilamid, bis-poliakrilamid fehérjegélen vizsgáltuk (16. ábra). A fehérjegélen látható eredmények alapján az 5. számú klónt választottuk ki az rNFAP2 nagymennyiségü termeléséhez.

\subsubsection{Az rNFAP2 termelése, tisztítása és azonosítása}

Az emelt hozamú rNFAP2 termelésére képes $P$. chrysogenum $\Delta$ paf/nfap2 törzs PCMM tápoldatban történő tenyésztését $\left(25^{\circ} \mathrm{C}\right.$-on, 4 napon át, $210 \mathrm{rpm}$ rázatás mellett) követően a felülúszóból kationcserés oszlopon tisztítottuk a fehérjét. A fehérjét tartalmazó egyesített frakciókkal elvégzett fehérje-gélelektroforézis során csak egy sáv jelent meg az NFAP2 molekulatömegével megegyező méretben (17. ábra).

$\mathrm{Az}$ elektrospray ionizációs tömegspektrométerrel (ESI-MS) végzett analízis megerősítette, hogy a tisztított fehérje monoizotópos molekulatömege 5555,4346 Da, ami megfelel az NFAP2 korábban mért monoizotópos moláris tömegének (5555,4380 Da) (18. és 9. ábrák). Ez az eredmény bizonyítja azt, hogy a $P$. chrysogenum $\Delta p a f / n f a p 2$ törzs képes megfelelően érett, 3 intramolekuláris diszulfid-híddal stabilizált NFAP2 termelésére. Az általunk alkalmazott kromatográfiás módszerrel 1000 ml fermentléből 15ะ1,2 mg rNFAP2t sikerült tisztítanunk. Az átlagérték 2 párhuzamos fehérjetermelésből származik. 


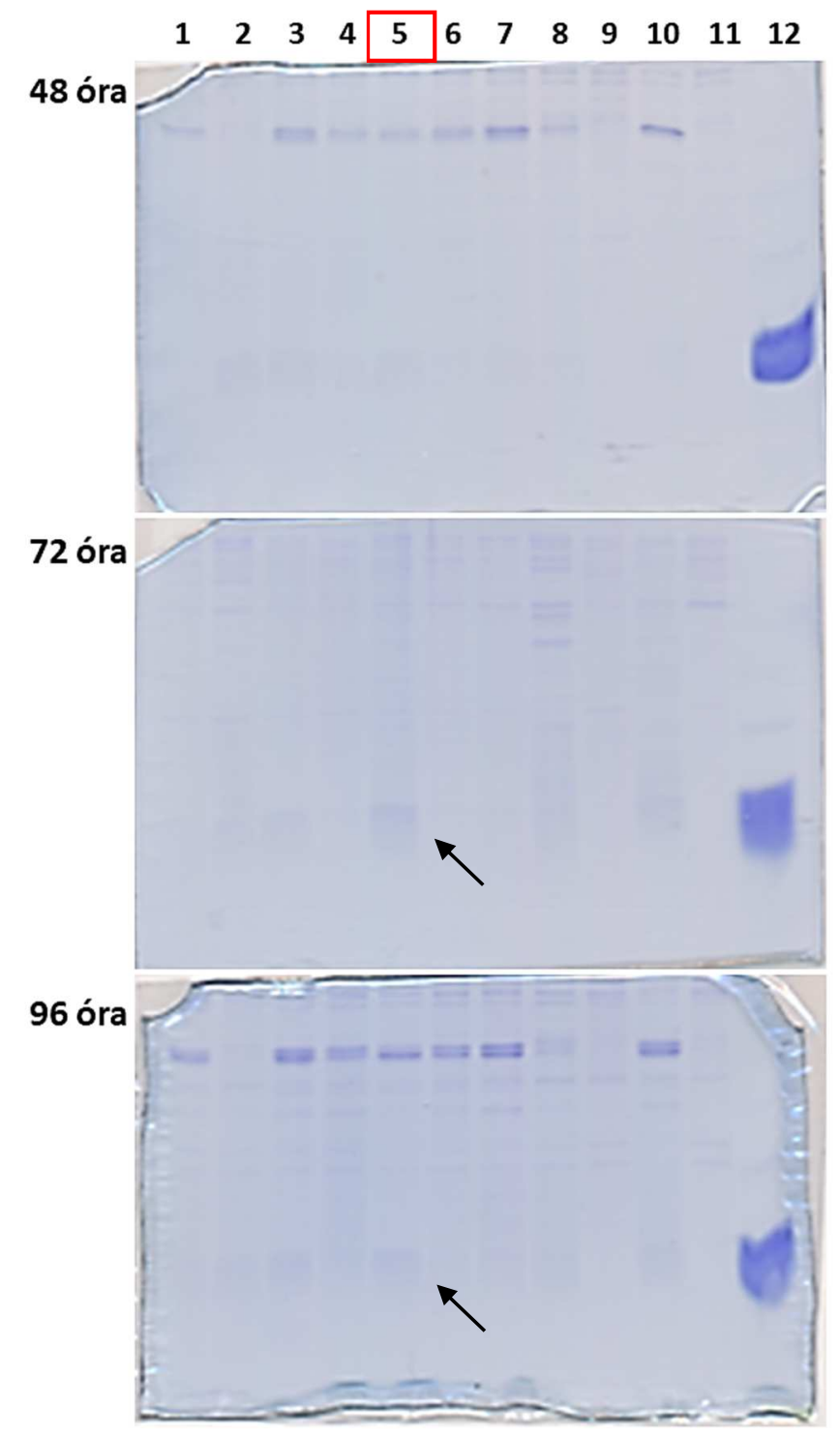

16. ábra. Eltérő $P$. chrysogenum $\triangle p a f / n f a p 2$ klónok extracelluláris fehérjeexpressziós mintázata 48, 72 és 96 órán át $25{ }^{\circ} \mathrm{C}-o n, 210 \mathrm{rpm}$ rázatás mellett történő tenyésztés után PCMM tápközegben (18\% trisglicin SDS-PAGE, Commassie-kék festés). 1-10: P. chrysogenum Apaf/nfap2 1-10 transzformáns klónok, 11: P. chrysogenum $\triangle p a f, 12$ : natív NFAP2 (15 $\mu \mathrm{g})$. Piros keret jelöli a termelésre kiválasztott klón számát, a fekete nyíl pedig az rNFAP2 jelenlétét.

A szakirodalom már korábban beszámolt az általunk alkalmazott $P$. chrysogenumalapú expressziós rendszerrel történő rekombináns NFAP termeléséről. A $N$. fischeri NRRL 181 natív termelöhöz képest azonban csak háromszor nagyobb mennyiségü NFAP hozam volt elérhető (Sonderegger és mtsi., 2016). A munkánk során létrehozott, rNFAP2 termelésére képes $P$. chrysogenum expressziós törzs 40-szer több proteint termel, mint a $N$. fischeri NRRL 181. Az NFAP2 antifungális hatásvizsgálata során megállapított MIC értékekhez viszonyítva ez a mennyiség rendkívül magas (7. táblázat). 
A

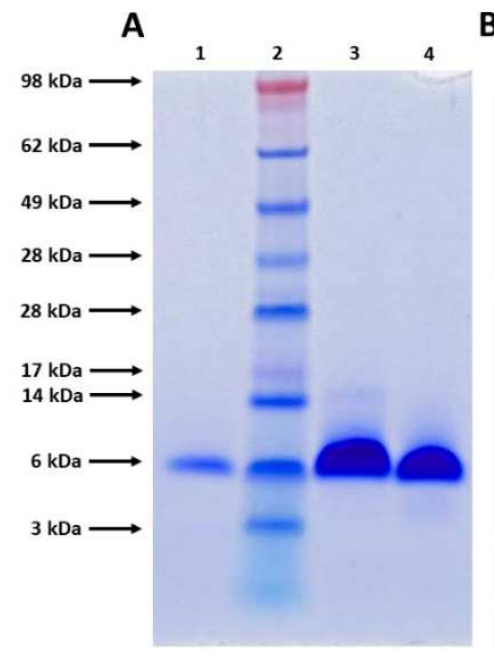

B

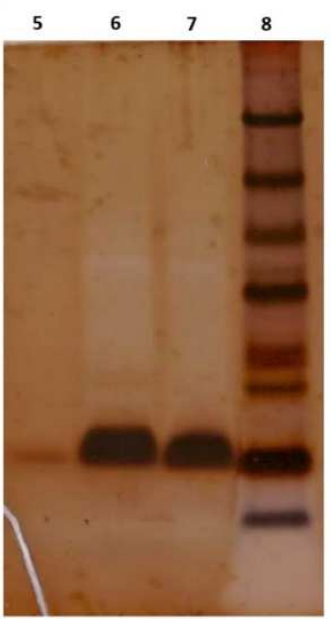

17. ábra. A natív, rekombináns és szintetikus NFAP2 elektroforetogramja 4-12\% Bis-Tris SDS-PAGEen Commassie-kék festés (A) és ezüst-festés (B) után. 1: NFAP2 $(2 \mu \mathrm{g})$, 2: molekulasúly marker (SeeBlue ${ }^{\mathrm{TM}}$ Plus2 Pre-stained Protein Standard, Thermo Fisher Scientific), 3: rNFAP2 (10 $\mu \mathrm{g}), 4$ : szNFAP2 (10 $\mu \mathrm{g}), 5$ : NFAP2 $(2 \mu \mathrm{g}), 6$ : rNFAP2 $(10 \mu \mathrm{g}), 7$ : szNFAP2 $(10 \mu \mathrm{g}), 8$ : molekulasúly marker (SeeBlue ${ }^{\mathrm{TM}}$ Plus 2 Pre-stained Protein Standard, Thermo Fisher Scientific). NFAP2, rNFAP2, szNFAP2: natív, rekombináns és szintetikus Neosartorya fischeri antifungális protein 2.

A

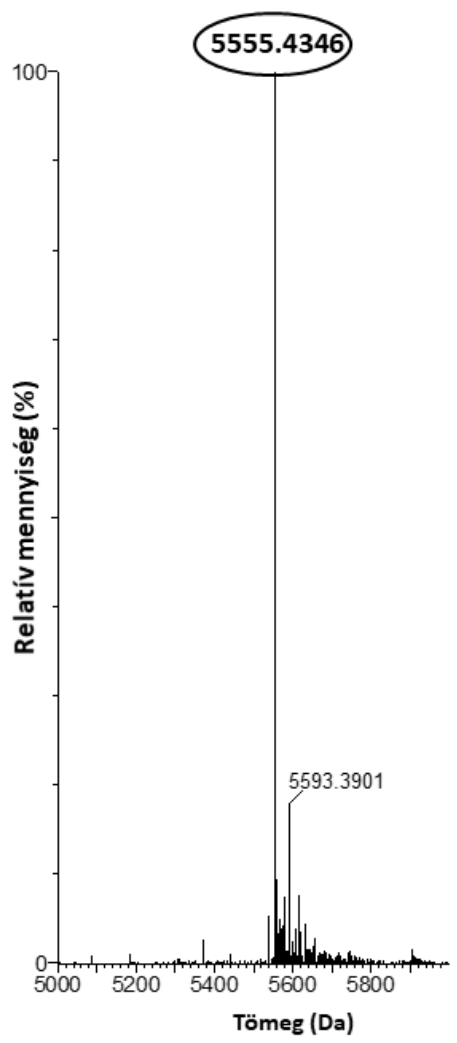

B

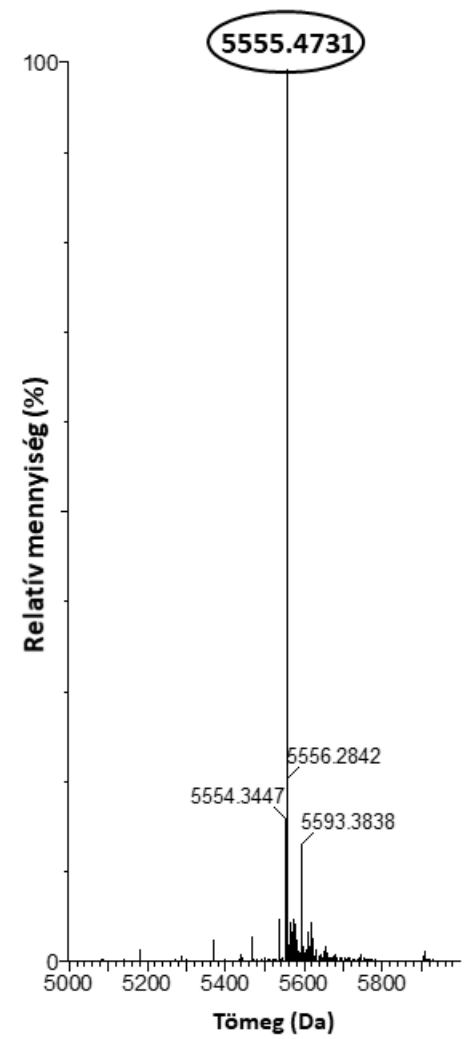

18. ábra. A rekombináns (A) és szintetikus (B) NFAP2 monoizotópos tömegspektruma. rNFAP2 és szNFAP2: rekombináns és szintetikus Neosartorya fischeri antifungális protein 2. 


\subsection{Az NFAP2 kémiai szintézise}

A vizsgálatokhoz szükséges nagy mennyiségü NFAP2 előállítására szilárd fázisú peptidszintézissel létrehozott NFAP2 fragmensek natív kémiai ligációval történő összekapcsolása is alkalmas módszer lehet. Az NFAP2 kémiai szintéziséhez az NFAP2 Cterminális felét (Fr-1 fragmens) a C-terminálison karboxil-csoportot hordozva, az Nterminális felét pedig tioészter formában szintetizáltuk (Fr-2t fragmens), hogy lehetővé tegyük az utóbbi natív kémiai ligációját az Fr-1 fragmenssel (Váradi és mtsi., 2013). A tisztított ligációs termék cisztein-tiol-csoportjainak diszulfid-hidakká történő oxidációját GSH-t és GSSG-t 1:1 arányban tartalmazó glutation-redox pufferben végeztük el. Az alkalmazott oxidatív körülmények között kialakulhat a feltételezett natív NFAP2-re jellemző „abcabc” duszilfid-híd mintázat, amit a 6.10.1. fejezetben tárgyalásra kerülő RP-HPLC eredmények is megerősítettek. Az alkalmazott szintézis módszer lépéseit a 19. ábra foglalja össze.

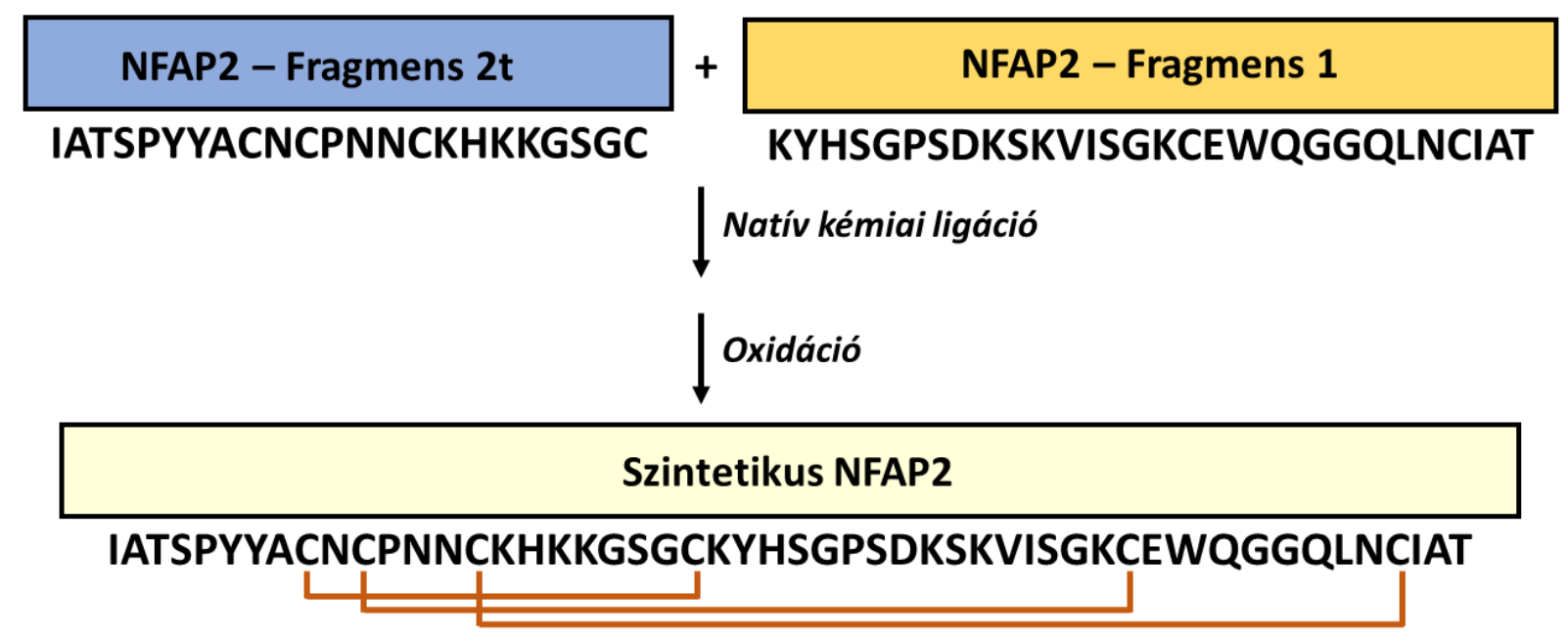

19. ábra. Az szNFAP2 előállításának folyamata. A kialakult diszulfid-hidakat barna vonalakkal jelöltük. szNFAP2: szintetikus Neosartorya fischeri antifungális protein 2.

Az szNFAP2 létrejöttét ESI-MS analízissel ellenőriztük, ami kimutatta, hogy a ligáció során nyert termék monoizotópos molekulatömege 5555,4731 Da (18. ábra), ami megfelel a három diszulfid-hidat tartalmazó natív NFAP2 monoizotópos molekulatömegének (9. ábra). Ez az eredmény egyértelmüen bizonyítja, hogy a szintetikus protein három intramolekuláris diszulfid-híddal rendelkezik. Az szNFAP2 tisztaságát és migrációs profilját fehérje-gélelektroforézissel ellenőriztük, ami az NFAP2 méretével megegyező proteint mutatott ki (17. ábra). A natív kémiai ligálás során a redukált szNFAP2 mennyisége $40-42 \%$, az oxidálté pedig 23-25\% volt. A szNFAP2 összhozama négy HPLC 
tisztítási lépést követően 2-3\% -ra csökkent, így 280 mg Fr-1 és Fr-2t-böl átlagosan 5-6 mg tiszta szNFAP2-t lehetett elöállítani.

A cgAFP-k kémiai szintéziséről már korábban beszámoltak a szakirodalomban. Váradi és mtsi. (2013) az szNFAP2 elöállítása során alkalmazott módszerrel már antifungálisan aktív PAF-ot is létrehoztak. A két protein szintézise során elért eredmények rámutatnak arra, hogy ez a módszer más élőlényekből származó, cisztein-gazdag antimikrobiális fehérjék előállítására is alkalmas lehet.

\subsection{A rekombináns és szintetikus NFAP2 antifungális hatásának vizsgálata}

\subsubsection{A rekombináns és szintetikus NFAP2 MIC értékének meghatározása LCM tápoldatban}

A rekombináns és szintetikus NFAP2 antifungális hatékonyságának vizsgálatára in vitro mikrodilúciós tesztet alkalmaztunk. Az rNFAP2 MIC értékeinek LCM tápoldatban történő meghatározásához az NFAP2 vizsgálata során alkalmazott kilenc, míg az szNFAP2 esetében négy élesztőgomba izolátumot vontuk be (8. táblázat).

8. táblázat. A natív, rekombináns és szintetikus NFAP2 minimális gátló koncentrációja LCM tápoldatban 48 óra, $30^{\circ} \mathrm{C}$-on történő inkubációt követően.

\begin{tabular}{lccc}
\hline & \multicolumn{3}{c}{ MIC $(\boldsymbol{\mu g} / \mathbf{m l})$} \\
\hline Protein, peptid / Izolátum & NFAP2 & rNFAP2 & szNFAP2 \\
\hline Candida albicans ATCC 10231 & 6,25 & 6,25 & 6,25 \\
Candida glabrata CBS 138 & 1,56 & 1,56 & n.a. \\
Candida guilliermondii CBS 566 & 1,56 & 1,56 & n.a. \\
Candida krusei CBS 573 & 12,5 & 12,5 & 12,5 \\
Candida lusitaniae CBS 6936 & 3,125 & 3,125 & n.a. \\
Candida parapsilosis CBS 604 & 1,56 & 1,56 & 1,56 \\
Candida tropicalis CBS 94 & 1,56 & 1,56 & n.a. \\
Saccharomyces cerevisiae SZMC 0644 & 3,125 & 3,125 & 3,125 \\
Schizosaccharomyces pombe SZMC 0142 & 1,56 & 1,56 & n.a. \\
\hline MIC: minimális gátló koncentráció, NFAP2, rNFAP2, szNFAP2: natív, rekombináns és & szintetikus \\
Neosartorya fischeri antifungális protein 2. & & &
\end{tabular}

Mind a két protein teljes növekedésgátlást eredményezett az élesztőgombák esetében a vizsgált koncentrációtartományon belül. Nem volt különbség a rekombináns, szintetikus és natív fehérje ugyanazon gomba izolátummal szemben mutatott MIC értéke között. A vizsgált fajtól függően a MIC értékek 1,56 és 12,5 $\mu \mathrm{g} / \mathrm{ml} \mathrm{között} \mathrm{változtak} 48$ óra inkubációt követően 
(8. táblázat). Az rNFAP2 az NFAP2-höz hasonlóan dózisfüggő módon fejtette ki antifungális hatását (20. ábra). Az szNFAP2-t alacsony hozama miatt csak négy fajjal szemben teszteltük, azonban az eredmények alapján a többi, nem vizsgált faj esetében is ugyanazokat a MIC értékeket feltételezzük, mint a natív és rekombináns NFAP2 esetében. Az érzékenységi tesztek, a heterológ expressziós rendszer termelési eredményeivel együtt a P. chrysogenum-mal magas hozamban, gazdaságosan előállítható rNFAP2 potenciális klinikai alkalmazhatóságát vetik fel.
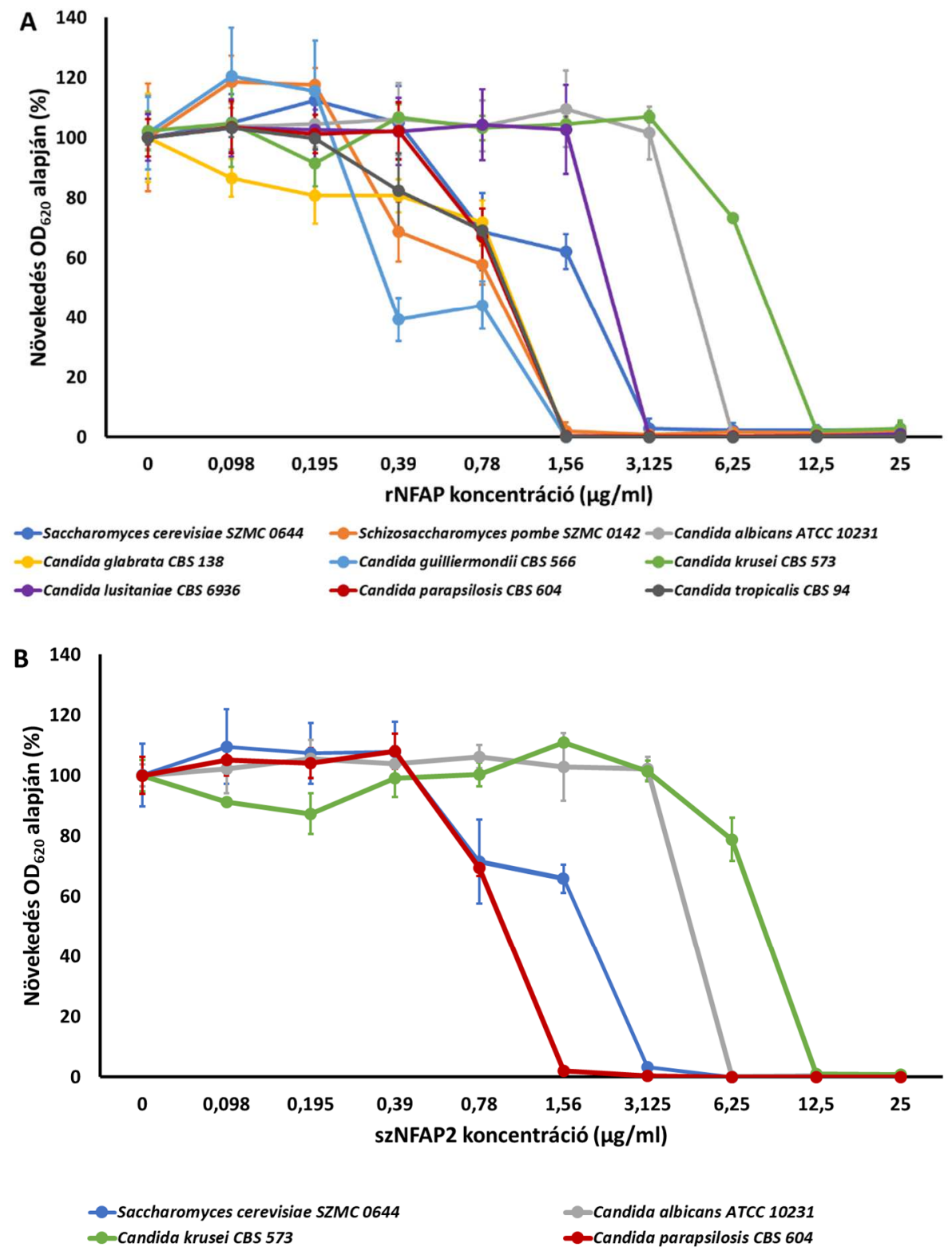

20. ábra. A rekombináns (A) és szintetikus (B) NFAP2 növekedésgátló hatékonysága LCM tápoldatban 48 órán át tartó, $30{ }^{\circ} \mathrm{C}$-on történő inkubációt követően. rNFAP2, szNFAP2: rekombináns és szintetikus Neosartorya fischeri antifungális protein 2. A kezeletlen kontrollhoz $(0 \mu \mathrm{g} / \mathrm{ml})$ tartozó fényelnyelés mértékét vettük $100 \%$-os növekedésnek. 


\subsubsection{Az rNFAP2 MIC értékének meghatározása RPMI 1640 tápoldatban}

Az rNFAP2 MIC értékeit sztenderd, klinikai mikrobiológiai körülmények között is meghatároztuk. A protein in vitro antifungális aktivitását humán patogén Candida fajokkal szemben RPMI 1640 tápoldatban vizsgáltuk, a CLSI-M27A3 módszer előírásainak megfelelően (Clinical and Laboratory Standards Institute, 2008). Az érzékenységi tesztek eredményeként megfigyelt MIC értékek a 9. táblázatban találhatók. A C. albicans ATCC 10231, a C. krusei CBS 573, a C. lusitaniae CBS 6936 és a C. tropicalis CBS 94 esetében $100 \mu \mathrm{g} / \mathrm{ml}$-nél magasabb MIC értékeket mértünk, azonban ez a dózis, a C. krusei CBS 573 kivételével, mintegy 50-70\%-kal csökkentette a gombák növekedését (21. ábra). A $C$. glabrata CBS 138, a C. guilliermondii CBS 566 és a C. parapsilosis CBS 604 törzsekkel szemben az rNFAP2 MIC értéke 12,5; 3,125 és $100 \mu \mathrm{g} / \mathrm{ml}$-nek adódott (9. táblázat, 21. ábra). Mindezek alapján az NFAP2 szisztémás, monoterápiás antifungális szerként való klinikai alkalmazhatósága korlátozott lehet, ezért megvizsgáltuk a protein szerkombinációban történő alkalmazásának lehetőségét is.

9. táblázat. Az rNFAP2, az FLK és a kombinációjuk esetén mért minimális gátló koncentrációk RPMI 1640 tápoldatban 48 órán át tartó, $35^{\circ} \mathrm{C}$-on történő inkubációt követően.

\begin{tabular}{lcccccc}
\hline \multicolumn{1}{c}{$\begin{array}{c}\text { Protein, antifungális szer/ } \\
\text { Izolátum }\end{array}$} & $\begin{array}{c}\text { MNFAP2 } \\
\text { (e) }\end{array}$ & $\begin{array}{c}\text { FLK } \\
(\mathbf{e})\end{array}$ & $\begin{array}{c}\text { rNFAP2 } \\
(\mathbf{k})\end{array}$ & $\begin{array}{c}\text { FLK } \\
(\mathbf{k})\end{array}$ & FICI & $\begin{array}{c}\text { Kölcsönhatás } \\
\text { típusa }\end{array}$ \\
\hline Candida albicans ATCC 10231 & $200^{*}$ & 1 & 6,25 & 0,25 & 0,28 & szinergista \\
Candida glabrata CBS 138 & 12,5 & n.a. & n.a. & n.a. & n.a. & n.a. \\
Candida guilliermondii CBS 566 & 3,125 & n.a. & n.a. & n.a. & n.a. & n.a. \\
Candida krusei CBS 573 & $400^{*}$ & 64 & 6,25 & 64 & 0,52 & indifferens \\
Candida lusitaniae CBS 6936 & $>100$ & n.a. & n.a. & n.a. & n.a. & n.a. \\
Candida parapsilosis CBS 604 & 100 & 8 & 6,25 & 1 & 0,19 & szinergista \\
Candida tropicalis CBS 94 & $>100$ & n.a. & n.a. & n.a. & n.a. & n.a. \\
\hline
\end{tabular}

*Ennél a törzsnél a 100 g/ml-nél nagyobb MIC értéket is meghatároztuk a FICI értékek kiszámításához. FICI: frakcionális gátló koncentráció index, FLK: flukonazol, MIC: minimális gátló koncentráció, rNFAP2: rekombináns Neosartorya fischeri antifungális protein 2 (e): az rNFAP2 és az FLK MIC értéke egyedüli alkalmazás esetén, (k): az rNFAP2 és az FLK MIC értéke kombinációban történő alkalmazás esetén. n.a.: nincs adat. 


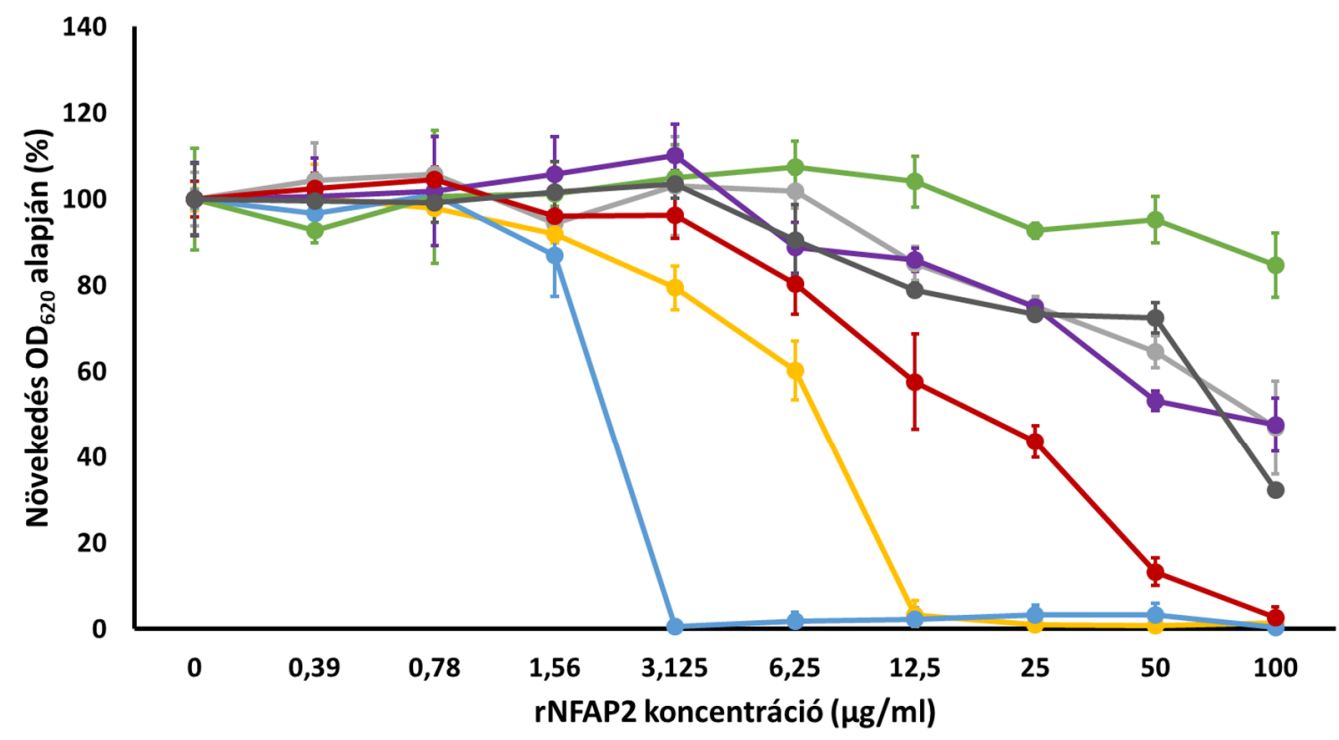

\footnotetext{
-Candida albicans ATCC 10231

-Candida krusei CBS 573

- Candida tropicalis CBS 94
}

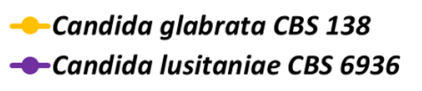

-Candida guilliermondii CBS 566

-Candida parapsilosis CBS 604

21. ábra. Az rNFAP2 növekedésgátló hatékonysága RPMI 1640 tápoldatban 48 órán át tartó, $35^{\circ} \mathrm{C}-0$ n történő inkubációt követően. rNFAP2: rekombináns Neosartorya fischeri antifungális protein 2. A kezeletlen kontrollhoz $(0 \mu \mathrm{g} / \mathrm{ml})$ tartozó fényelnyelés mértékét vettük 100\%-os növekedésnek.

\subsubsection{Az rNFAP2 és az FLK kölcsönhatásának vizsgálata}

A szerkombinációs tesztekbe a $C$. albicans-t és $C$. parapsilosis-t, mint a felnőttek, illetve az újszülöttek körében legelterjedtebb szisztémás fertőzést okozó opportunista humánpatogén élesztőgombákat, valamint a leggyakoribb azol-rezisztens fajt, a C. krusei-t vontuk be (Guinea, 2014). A kísérletet a CLSI-M27A3 dokumentumban leírt tesztkörülményeknek megfelelően hajtottunk végre (Clinical and Laboratory Standards Institute, 2008). A tesztek során az rNFAP2 kölcsönhatását FLK-val, a Candida fertőzések kezelésére leggyakrabban és elsődlegesen alkalmazott terápiás szerrel vizsgáltuk (Lockhart és mtsi., 2014). A kölcsönhatás típusának megállapításához szükséges frakcionális gátló koncentráció index (FICI) kiszámításához meghatároztuk az rNFAP2 és az FLK pontos MIC értékeit a C. albicans ATCC 10231 és C. krusei CBS 573 esetében is (9. táblázat). A FICI értékek alapján az rNFAP2 FLK-val történő együttes alkalmazása a $C$. albicans (ATCC 10231 ) és $C$. parapsilosis (CBS 604) esetében szinergista (FICI $=0,28$ és 0,19$)$, míg a $C$. krusei (CBS 573) esetében indifferens kölcsönhatást (FICI = 1,02) mutatott (9. táblázat). Az rNFAP2 és a FLK kombinált alkalmazása esetén észlelt teljes növekedésgátlást okozó vagy a növekedést hatékonyan visszaszorítani képes koncentrációkombinációkat a 22. ábra foglalja össze. 


\begin{tabular}{cccccccc}
\hline \multicolumn{7}{c}{ Candida albicans ATCC $\mathbf{1 0 2 3 1}$} \\
\hline $\begin{array}{c}\text { rNFAP2 / } \\
\text { FLK }\end{array}$ & $\mathbf{1 0 0}$ & $\mathbf{5 0}$ & $\mathbf{2 5}$ & $\mathbf{1 2 , 5}$ & $\mathbf{6 , 2 5}$ & $\mathbf{0}$ \\
\hline $\mathbf{1}$ & $0,25 \pm 0,36 \%$ & $0,59 \pm 0,83 \%$ & $0,67 \pm 0,95 \%$ & $0,34 \pm 0,47 \%$ & $0,84 \pm 1,18 \%$ & $1,17 \pm 0,95 \%$ \\
$\mathbf{0 , 5}$ & $\mathbf{0 , 4 2} \pm \mathbf{0 , 5 9} \%$ & $\mathbf{1 , 6 8} \pm \mathbf{0 , 7 1 \%}$ & $\mathbf{1 , 0 1} \pm \mathbf{1 , 4 2} \%$ & $\mathbf{1 , 5 1} \pm \mathbf{1 , 1 8 \%}$ & $\mathbf{3 , 4 3} \pm \mathbf{2 , 7 2} \%$ & $9,11 \pm 0,35 \%$ \\
$\mathbf{0 , 2 5}$ & $\mathbf{1 , 5 1} \pm \mathbf{1 , 1 8} \%$ & $\mathbf{3 , 4 3} \pm \mathbf{1 , 0 7} \%$ & $\mathbf{4 , 6 2} \pm \mathbf{1 , 5 5} \%$ & $9,46 \pm 1,30 \%$ & $10,55 \pm 1,42 \%$ & $21,52 \pm 8,17 \%$ \\
$\mathbf{0 , 1 2 5}$ & $20,85 \pm 4,38 \%$ & $31,49 \pm 2,13 \%$ & $29,23 \pm 3,67 \%$ & $25,29 \pm 1,90 \%$ & $50,92 \pm 6,40 \%$ & $60,44 \pm 3,12 \%$ \\
$\mathbf{0 , 0 6 2 5}$ & $32,69 \pm 0,98 \%$ & $54,05 \pm 0,08 \%$ & $58,59 \pm 0,88 \%$ & $67,24 \pm 0,60 \%$ & $71,47 \pm 0,01 \%$ & $81,02 \pm 3,48 \%$ \\
$\mathbf{0}$ & $43,22 \pm 4,50 \%$ & $65,66 \pm 2,37 \%$ & $97,04 \pm 9,78 \%$ & $98,69 \pm 0,90 \%$ & $104,56 \pm 1,85 \%$ & $100,28 \pm 0,40 \%$ \\
\hline
\end{tabular}

\section{B}

\begin{tabular}{|c|c|c|c|c|c|c|}
\hline \multicolumn{7}{|c|}{ Candida krusei CBS 573} \\
\hline $\begin{array}{l}\text { rNFAP2 / } \\
\text { FLK } \\
\end{array}$ & 100 & 50 & 25 & 12,5 & 6,25 & $\mathbf{0}$ \\
\hline 64 & $0,65 \pm 0,61 \%$ & $1,85 \pm 0,15 \%$ & $1,09 \pm 0,00 \%$ & $1,09 \pm 0,31 \%$ & $1,74 \pm 0,31 \%$ & $0,54 \pm 0,46 \%$ \\
\hline 32 & $3,26 \pm 3,07 \%$ & $15,54 \pm 3,23 \%$ & $19,13 \pm 2,46 \%$ & $27,83 \pm 0,61 \%$ & $33,8 \pm 1,38 \%$ & $66,96 \pm 4,30 \%$ \\
\hline 16 & $51,09 \pm 2,46 \%$ & $45,48 \pm 2,83 \%$ & $52,5 \pm 0,15 \%$ & $59,67 \pm 2,31 \%$ & $67,04 \pm 1,41 \%$ & $89,24 \pm 2,00 \%$ \\
\hline 8 & $107,61 \pm 4,92 \%$ & $107,28 \pm 0,15 \%$ & $107,83 \pm 2,46 \%$ & $94,35 \pm 9,84 \%$ & $100,65 \pm 1,38 \%$ & $100,76 \pm 2,61 \%$ \\
\hline 4 & $105,96 \pm 4,18 \%$ & $107,07 \pm 0,15 \%$ & $101,41 \pm 1,38 \%$ & $105,54 \pm 3,54 \%$ & $104,78 \pm 1,23 \%$ & $97,17 \pm 5,23 \%$ \\
\hline $\mathbf{0}$ & $100 \pm 15,99 \%$ & $99,24 \pm 12,14 \%$ & $100,11 \pm 2,31 \%$ & $105,33 \pm 3,23 \%$ & $109,13 \pm 2,15 \%$ & $103,59 \pm 5,07 \%$ \\
\hline \multicolumn{7}{|l|}{ C } \\
\hline \multicolumn{7}{|c|}{ Candida parapsilosis CBS 604} \\
\hline $\begin{array}{c}\text { rNFAP2 / } \\
\text { FLK }\end{array}$ & 100 & 50 & 25 & 12,5 & 6,25 & $\mathbf{0}$ \\
\hline 8 & $4,35 \pm 1,02 \%$ & $1,67 \pm 0,71 \%$ & $3,99 \pm 0,51 \%$ & $2,54 \pm 0,51 \%$ & $2,90 \pm 1,02 \%$ & $3,73 \pm 0,05 \%$ \\
\hline 4 & $3,93 \pm 0,58 \%$ & $5,43 \pm 0,51 \%$ & $3,26 \pm 0,51 \%$ & $4,05 \pm 0,42 \%$ & $2,87 \pm 1,63 \%$ & $7,9 \pm 1,02 \%$ \\
\hline 2 & $2,54 \pm 2,56 \%$ & $5,8 \pm 2,05 \%$ & $2,9 \pm 1,02 \%$ & $2,54 \pm 1,54 \%$ & $3,78 \pm 1,24 \%$ & $27,17 \pm 7,69 \%$ \\
\hline 1 & $5,8 \pm 2,05 \%$ & $6,16 \pm 1,54 \%$ & $2,90 \pm 1,03 \%$ & $2,54 \pm 2,56 \%$ & $6,23 \pm 1,64 \%$ & $73,41 \pm 2,77 \%$ \\
\hline 0,5 & $5,07 \pm 1,02 \%$ & $8,48 \pm 1,74 \%$ & $14,86 \pm 4,61 \%$ & $24,86 \pm 1,33 \%$ & $78,26 \pm 3,07 \%$ & $107,17 \pm 1,33 \%$ \\
\hline $\mathbf{0}$ & $2,54 \pm 1,54 \%$ & $6,52 \pm 2,05 \%$ & $35,29 \pm 2,36 \%$ & $103,48 \pm 3,48 \%$ & $101,52 \pm 0,10 \%$ & $104,78 \pm 6,76 \%$ \\
\hline
\end{tabular}

22. ábra. A C. albicans ATCC 10231 (A), a C. krusei CBS 573 (B) és a C. parapsilosis CBS 604 (C) növekedési százaléka az rNFAP2 és a FLK kombinált alkalmazása esetén RPMI 1640 tápoldatban 48 órán át tartó, $35{ }^{\circ} \mathrm{C}$-on történő inkubációt követően. A piros cellák a teljes növekedésgátlást (növekedés $<5 \%$ ), a narancssárga cellák a csökkent növekedési képességet (növekedés 5\% és 90\% között), a zöld cellák pedig a teljes növekedést (növekedés $90 \%$ és 100\% között) jelölik. A növekedést teljesen visszaszorítani képes, a szerek önmagukban történő alkalmazása során megállapított MIC értéknél alacsonyabb koncentrációkat fekete kerettel jelöltük, a hozzájuk tartozó növekedés százalékokat pedig félkövér betűvel emeltük ki. FLK: flukonazol, rNFAP2: rekombináns Neosartorya fischeri antifungális protein 2.

Az antifungális hatásvizsgálatok során megállapítottuk, hogy az rNFAP2 és az szNFAP2 a natív fehérjével megegyező antifungális aktivitást mutat és 48 óra elteltével is teljes növekedésgátlást eredményez a vizsgált törzseknél. Mindezek mellett az a tény, hogy 
az rNFAP2 az iparban használt penicillin-termelő törzsek ,generally recognized as safe" státuszú szülöi törzsével, a $P$. chrysogenum Q176-tal nagy mennyiségben és gazdaságosan megtermeltethető, lehetőséget adhat a protein antifungális szerként való klinikai alkalmazására antimikotikumokkal szemben rezisztens Candida törzsek által okozott fertőzések kezelésében. Míg az rNFAP2 az alacsony kationtartalmú LCM tápoldatban alacsony koncentrációban gátolta az élesztőgombák növekedését, addig a komplex, nagy kationtartalmú RPMI 1640 tápoldatban az antifungális hatása drasztikusan lecsökkent (8. és 9. táblázatok). Mivel az RPMI 1640 a humán szérum összetételét imitálja, az rNFAP2 szisztémás alkalmazási lehetősége megkérdőjelezhető, azonban felületi szerként alkalmazható lehet gombafertőzések kezelésére, mint ahogy azt a PAF esetében már korábban felvetették (Galgóczy és mtsi., 2008). A PAF és az NFAP esetében is leírták, hogy RPMI 1640 tápoldatban magas MIC értékeket mutatnak humán patogén dermatofitákkal (Galgóczy és mtsi., 2008), Aspergillus-okkal és Fusarium-okkal szemben (Virágh és mtsi., 2014). Mindezek az eredmények, más korábbi vizsgálatokkal együtt azt jelzik, hogy a tápoldatban magas koncentrációban jelenlévő kationok csökkenthetik a cgAFP-k hatékonyságát (Kaiserer és mtsi., 2003; Galgóczy és mtsi., 2017).

A különböző hatásmechanizmussal rendelkező antifungális szerek kombinációban történő alkalmazására általában akkor kerül sor, ha a szerekkel szemben a fertőzést okozó gomba kisfokú érzékenységet vagy rezisztenciát mutat, illetve, ha a hosszú ideig tartó, nagymennyiségü monoterápiás szerhasználat súlyos mellékhatásokat okozhat a gazdaszervezetben. Az antifungális szerek kombinációban történő alkalmazása hatékonyabbá teheti a kezelést, rövidítheti annak időtartamát, továbbá lehetővé teheti az alkalmazott hatékony dózis csökkentését és mindezek által csökkentheti a rezisztencia és a mellékhatások kialakulásának kockázatát. Mivel az FLK olcsó és könnyen hozzáférhető antifungális szer, ezért ez a leggyakrabban és elsődlegesen alkalmazott antimikotikum a Candida fajok által okozott fertőzések kezelésére (Gonçalves és mtsi., 2016; Bailly és mtsi., 2016). Az NFAP2 FLK-val történő együttes alkalmazása a C. albicans és $C$. parapsilosis esetében szinergista kölcsönhatásban csökkentette az antifungális szer hatékony növekedésgátló in vitro dózisát. Hasonló eredményről már korábban beszámoltak, amikor is a PAF FLK-val történő együttes alkalmazása jelentős mértékben gátolta a dermatofita fajok növekedését (Galgóczy és mtsi., 2008).

Ezekre az ígéretes eredményekre alapozva az FLK - cgAFP kombináció új terápiás stratégiát jelenthet a gombafertőzések kezelésében, azonban ennek bizonyítására részletes in vivo farmakoterápiás és klinikai vizsgálatokra van szükség. 


\subsection{Az NFAP2 funkcionális térképezése}

\subsubsection{NFAP2 peptidfragmensek szintézise}

Az NFAP2 funkcionális térképezéséhez szükséges peptidfragmensek előállítására szilárd fázisú peptidszintézist alkalmaztunk. A két fél (Fragmens 1 és 2 (Fr-1 és Fr-2), 10. táblázat) és a négy negyed (Fragmens 3-6 (Fr-3-6), 10. táblázat) NFAP2 peptidfragmenst szilárd hordozón Boc vagy Fmoc kémiával szintetizáltuk meg (7. ábra). A szintetizált peptidfragmensek teljes egészében lefedték az érett NFAP2 szekvenciáját. A peptideket preparatív RP-HPLC-vel tisztítottuk és a termékeket ESI-MS analízissel ellenőriztük (nem közölt adatok). A szintetizált peptidfragmensek fizikai-kémiai tulajdonságait a 10. táblázat foglalja össze.

10. táblázat. Az érett NFAP2 és szintetikus peptidfragmenseinek aminosavszekvenciája és in silico meghatározott fizikai és kémiai tulajdonságai.

\begin{tabular}{|c|c|c|c|c|c|c|c|}
\hline Protein/peptid & $\begin{array}{l}\text { Aminosavak } \\
\text { szá ma }\end{array}$ & $\begin{array}{l}\text { Molekulatömeg } \\
\quad(\text { kDa) }\end{array}$ & $\begin{array}{l}\text { Ciszteinek } \\
\text { szá ma }\end{array}$ & $\begin{array}{l}\text { Lizin/arginin } \\
\text { szám }\end{array}$ & pI & $\begin{array}{l}\text { Becsült } \\
\text { töltés } \\
\text { (pH 7) }\end{array}$ & GRAVY \\
\hline \multicolumn{8}{|c|}{ IATSPYYACNCPNNCKHKKGSGCKYHSGPSDKSKVISGKCEWQGGQLNCIAT } \\
\hline NFAP2 & 52 & 5,6 & 6 & $7 / 0 /$ & 9,01 & $+5,2$ & $-0,731$ \\
\hline \multicolumn{8}{|c|}{ KYHSGPSDKSKVISGKC(-SH)EWQGGQLNC(-SH)IAT } \\
\hline Fragmens 1 & 29 & 3,1 & 2 & $4 / 0$ & 8,79 & $+2,1$ & $-0,752$ \\
\hline \multicolumn{8}{|c|}{$\begin{array}{l}\text { IATSPYYAC(-SH)NC(-SH)PNNC(-SH)KHKKGSGC(-SH) } \\
\text { kevert aminosavsorrendú változat: IAGAHKC(-SH)KPC(-SH)YGYKTNSC(-SH)C(-SH)NSPN }\end{array}$} \\
\hline Fragmens 2 & 23 & 2,5 & 4 & $3 / 0$ & 8,87 & $+3,0$ & $-0,704$ \\
\hline \multicolumn{8}{|c|}{ GKC(-SH)EWQGGQLNC(-SH)IAT } \\
\hline Fragmens 3 & 15 & 1,6 & 2 & $1 / 0$ & 5,99 & $-0,2$ & $-0,373$ \\
\hline \multicolumn{8}{|c|}{$\begin{array}{c}\text { NNC(-SH)KHKKGSGC(-SH) } \\
\text { kevert aminosavsorrendú változat: C(-SH)C(-SH)NKGKNKGSH }\end{array}$} \\
\hline Fragmens 4 & 11 & 1,2 & 2 & $3 / 0$ & 9,39 & $+3,1$ & $-1,682$ \\
\hline \multicolumn{8}{|c|}{ KYHSGPSDKSKVIS } \\
\hline Fragmens 5 & 14 & 1,5 & 0 & $3 / 0$ & 9,53 & $+2,1$ & $-1,157$ \\
\hline \multicolumn{8}{|c|}{ IATSPYYAC(-SH)NC(-SH)P } \\
\hline Fragmens 6 & 12 & 1,3 & 2 & $0 / 0$ & 5,51 & $-0,2$ & $+0,192$ \\
\hline
\end{tabular}

GRAVY: átlagos hidrofóbicitás érték, NFAP2: Neosartorya fischeri antifungalis protein 2.

\subsubsection{Az SZNFAP2 peptidfragmensek antifungális hatásámechanizmusának vizsgálata}

A teljes hosszúságú antifungális fehérjékből származó peptidfragmensek gombaellenes hatásának vizsgálata lehetővé teszi a lehetséges, antifungálisan aktív fehérjemotívumok azonosítását (Garrigues és mtsi., 2017). Az NFAP2 antifungálisan aktív helyének felderítésére a protein hat szintetikus peptidfragmensének (Fragmensek 1-6, Fr-1- 
6, 10. táblázat és 23. ábra) gombaellenes hatását LCM tápoldatban, in vitro mikrodilúciós tesztben vizsgáltuk. A tesztek során csak az Fr-2 és az Fr-4 peptidfragmens mutatott dózisfüggő, antifungális hatást a vizsgálatba bevont 4 élesztőgomba ellen ( $C$. albicans ATCC 10231, C. krusei CBS 573, C. parapsilosis CBS 604, S. cerevisiae SZMC 0644) (24. ábra). Azonban a peptidfragmensek MIC értékei (50 $\mu \mathrm{g} / \mathrm{ml}$ minden esetben) magasabbak voltak, mint az azonos kísérleti körülmények között, a teljes hosszúságú NFAP2-vel végzett érzékenységi tesztek során meghatározott értékek $(12,5-1,56 \mu \mathrm{g} / \mathrm{ml})$ (11. táblázat). Figyelembe véve azt, hogy az Fr-4 az Fr-2 C-terminális része, és az Fr-2 N-terminális Fr-6 része nem mutatott antifungális aktivitást (23. ábra), azt feltételezzük, hogy az NFAP2 Nterminálisának középső része (vagyis az Fr-4, 23. ábra) felelős az antifungális aktivitásért.

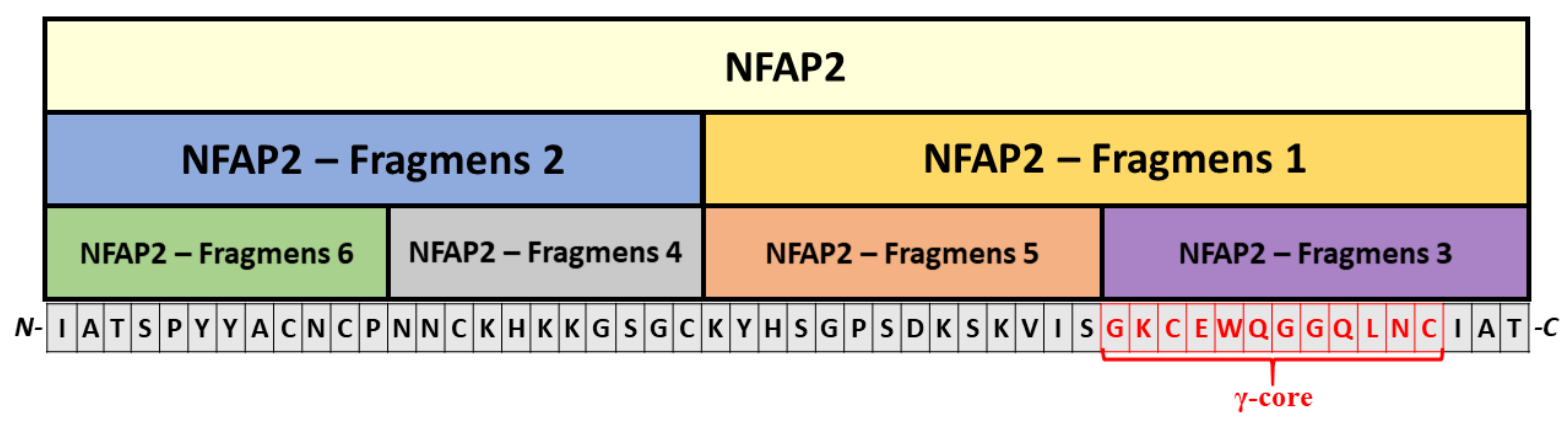

23. ábra. Az NFAP2 funkcionális térképezéséhez használt peptidfragmensek aminosavsorrendje. A $\gamma$ core motívumot piros betüvel emeltük ki. NFAP2: Neosartorya fischeri antifungális protein 2.

Annak a kérdésnek a megválaszolására, hogy vajon az Fr-4 által kifejtett antifungális hatás az adott szakasz elsődleges szerkezetétől vagy annak fizikai-kémiai tulajdonságaitól függ, elöállítottuk az Fr-2 és az Fr-4 véletlenszerüen kevert aminosavsorrendü változatait is (Kr-Fr-2 és Kr-Fr-4, 10. táblázat) és megvizsgáltuk azok antifungális hatékonyságát. Mindkét változat az Fr-2 és Fr-4 esetében megfigyelt gátló potenciált és MIC értéket mutatta (25. ábra, 11. táblázat). Ez az eredmény azt bizonyítja, hogy az NFAP2 antifungális hatása elsősorban az N-terminális régió középső részének nettó pozitív töltésétől és hidrofil jellegétől függ, nem pedig az adott proteinszakasz elsődleges szerkezetétől.

Érdemes megemlítenünk, hogy az NFAP2 C-terminális része tartalmazza az ún. $\gamma$ core motívumot ([GXC]-[X $\left.\mathrm{X}_{3-9}\right]-[\mathrm{C}]$, 23. ábra), ami fontos szerepet játszik az állati- és humán-eredetű antifungális proteinek, illetve az antifungális növényi defenzinek antimikrobiális aktivitásában vagy szerkezetének kialakításában (Lacerda és mtsi., 2014). Leírták, hogy a szintetikus $\gamma$-core peptidek, amik az N-vagy a C-terminálisukon három extra 
aminosavat hordoznak, antimikrobiálisan aktívak lehetnek (Yount és Yeaman, 2004). Érdekes módon az NFAP2 $\gamma$-core motívumot ( $N$-GKCEWQGGQLNC-C) 3 másik aminosavval együtt tartalmazó Fr-3 peptidfragmens (23. ábra és 10. táblázat) nem gátolta az élesztők növekedését (11. táblázat). Ezt az eredményt figyelembe véve azt feltételezzük, hogy ez a specifikus peptidmotívum önmagában nem rendelkezik élesztőellenes funkcióval, azonban szerkezetkialakító-szerkezetstabilizáló szerepe lehetséges.
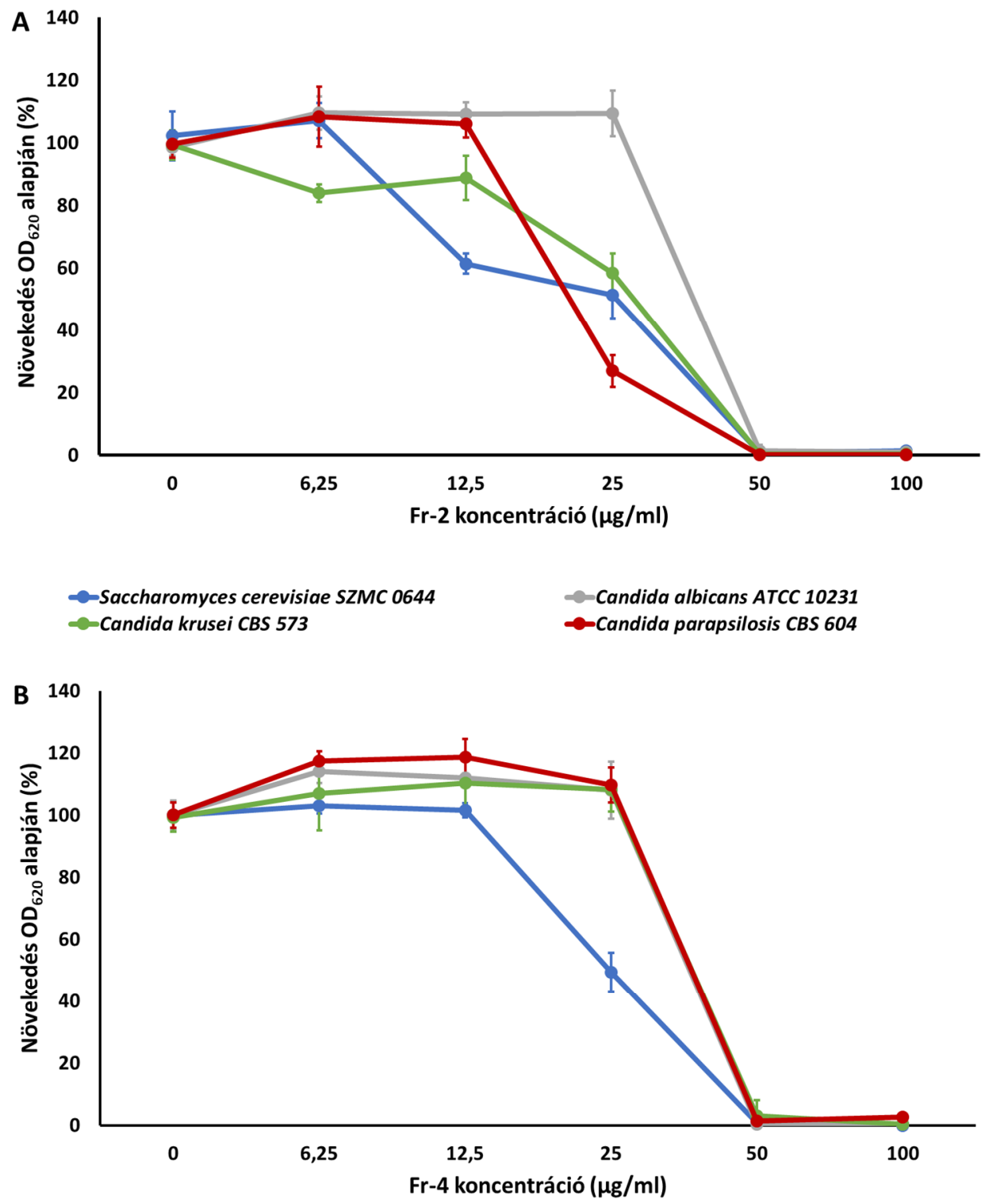

$\begin{array}{ll}- \text { Saccharomyces cerevisiae SZMC } 0644 & - \text { Candida albicans ATCC } 10231 \\ - \text { Candida krusei CBS } 573 & - \text { Candida parapsilosis CBS } 604\end{array}$

24. ábra. Az szNFAP2 Fr-2 (A) és Fr-4 (B) peptidfragmensek növekedésgátló hatékonysága LCM tápoldatban 48 órán át tartó, $30^{\circ} \mathbf{C}$-os inkubációt követően. szNFAP2: szintetikus Neosartorya fischeri antifungális protein 2. A kezeletlen kontrollhoz $(0 \mu \mathrm{g} / \mathrm{ml})$ tartozó fényelnyelés mértékét vettük $100 \%$-os növekedésnek. 
11. táblázat. Az NFAP2 és szintetikus peptidfragmenseinek minimális gátló koncentrációja (MIC) LCM tápoldatban 48 órán át tartó, $30{ }^{\circ} \mathrm{C}$-os inkubációt követően.

\begin{tabular}{lccccccccc}
\hline \multicolumn{7}{c}{ MIC $(\boldsymbol{\mu g} / \mathbf{m l})$} \\
\hline Protein, peptid / Izolátum & NFAP2 & Fr-1 & Fr-2 & Kr-Fr-2 & Fr-3 & Fr-4 & Kr-Fr-4 & Fr-5 & Fr-6 \\
\hline Candida albicans ATCC 10231 & 6,25 & $>100$ & 50 & 50 & $>100$ & 50 & 50 & $>100$ & $>100$ \\
Candida glabrata CBS 138 & 1,56 & n.a. & n.a. & n.a. & n.a. & n.a. & n.a. & n.a. & n.a. \\
Candida guilliermondii CBS 566 & 1,56 & n.a. & n.a. & n.a. & n.a. & n.a. & n.a. & n.a. & n.a. \\
Candida krusei CBS 573 & 12,5 & 100 & 50 & 50 & $>100$ & 50 & 50 & $>100$ & $>100$ \\
Candida lusitaniae CBS 6936 & 3,125 & n.a. & n.a. & n.a. & n.a. & n.a. & n.a. & n.a. & n.a. \\
Candida parapsilosis CBS 604 & 1,56 & $>100$ & 50 & 50 & $>100$ & 50 & 50 & $>100$ & $>100$ \\
Candida tropicalis CBS 94 & 1,56 & n.a. & n.a. & n.a. & n.a. & n.a. & n.a. & n.a. & n.a. \\
Saccharomyces cerevisiae SZMC 0644 & 3,125 & 100 & 50 & 50 & $>100$ & 50 & 50 & $>100$ & $>100$ \\
Schizosaccharomyces pombe SZMC 0142 & 1,56 & n.a. & n.a. & n.a. & n.a. & n.a. & n.a. & n.a. & n.a. \\
\hline
\end{tabular}

Fr-1-6: szNFAP2 peptidfragmensei 1-6., Kr-Fr-2 és 4: szNFAP2 2 és 4 peptidfragmens kevert aminosavsorrendü változatai. MIC: minimális gátló koncentráció, NFAP2 és szNFAP2: natív és szintetikus Neosartorya fischeri antifungális protein 2. n.a.: nincs adat.

Korábbi tanulmányok bebizonyították, hogy az antifungális fehérjék, azok szintetikus peptidfragmensei és célzottan tervezett változataik növekedésgátló hatást mutatnak, illetve plazmamembrán roncsoló hatást fejthetnek ki abban az esetben, ha hidrofilek és nagymértékű pozitív össztöltéssel rendelkeznek (Sagaram és mtsi., 2011; Garrigues, és mtsi., 2017). A 6.4.2. fejezet eredményei alapján az NFAP2 roncsolja az élesztősejtek plazmamembránját. Feltételezésünk szerint ezért a hatásért az Fr-4, a protein nagymértékben hidrofil és pozitívan töltött N-terminális középrégiója a felelős (23. ábra és 10. táblázat). Ennek bizonyítására vizsgáltuk az Fr-2, Fr-4, a kevert aminosavsorrendü változataik ( $\mathrm{Kr}-\mathrm{Fr}-2$ és $\mathrm{Kr}-\mathrm{Fr}-4)$ és az Fr-3 plazmamembrán roncsoló hatását PI-festéssel, összehasonlítva a teljes hosszúságú proteinnel. A minimális gátló koncentrációban alkalmazott Fr-2, Fr-4, illetve Kr-Fr-2 és Kr-Fr-4 10 percen belül plazmamembrán roncsoló hatást fejtettek ki a C. albicans ATCC 10231 sejteken, a natív, szintén MIC koncentrációban alkalmazott NFAP2-höz hasonlóan (26. ábra). Ezzel szemben a $\gamma$-core régiót tartalmazó Fr3 paptidfragmenssel kezelt sejtek nem muttattak PI festödést (26. ábra). Ezek az eredmények tovább erősítik a korábban tárgyalt feltételezésünket, miszerint az N-terminális középső régió felelős az NFAP2 antifungális hatásáért, míg a $\gamma$-core motívum feltételezhetően szerkezetkialakító-szerkezetstabilizáló szerepet tölt be. 


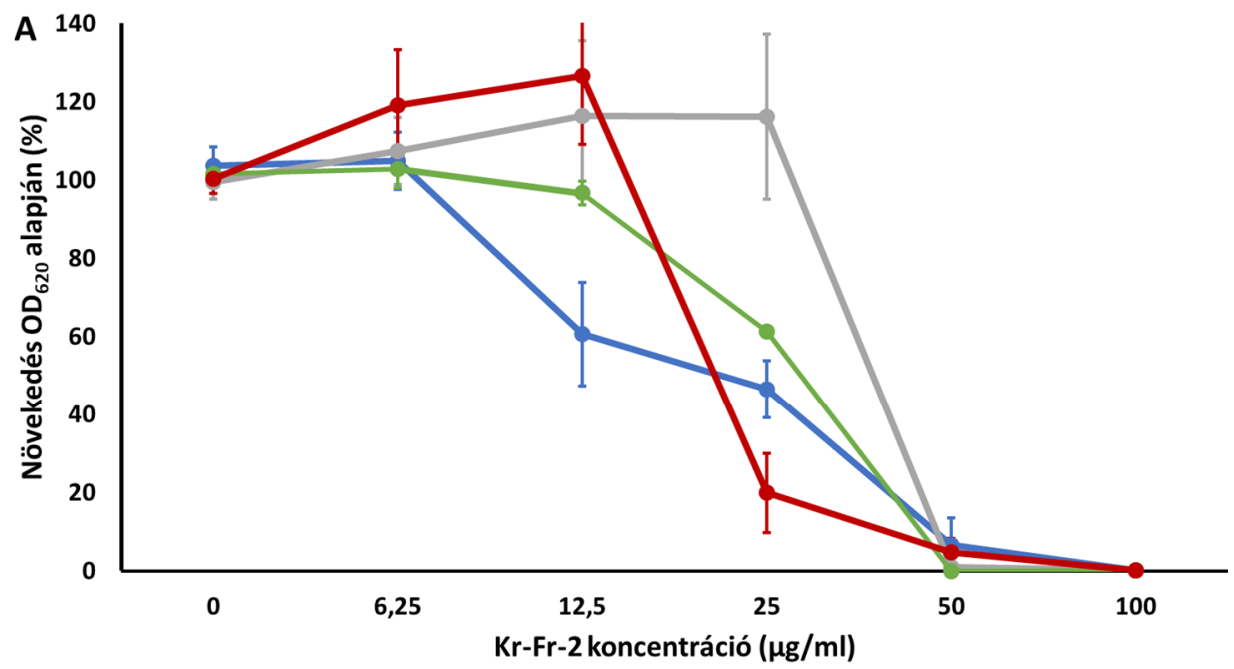

$\begin{array}{ll}- \text { Saccharomyces cerevisiae SZMC } 0644 & - \text { Candida albicans ATCC } 10231 \\ - \text {-Candida krusei CBS } 573 & - \text { Candida parapsilosis CBS } 604\end{array}$

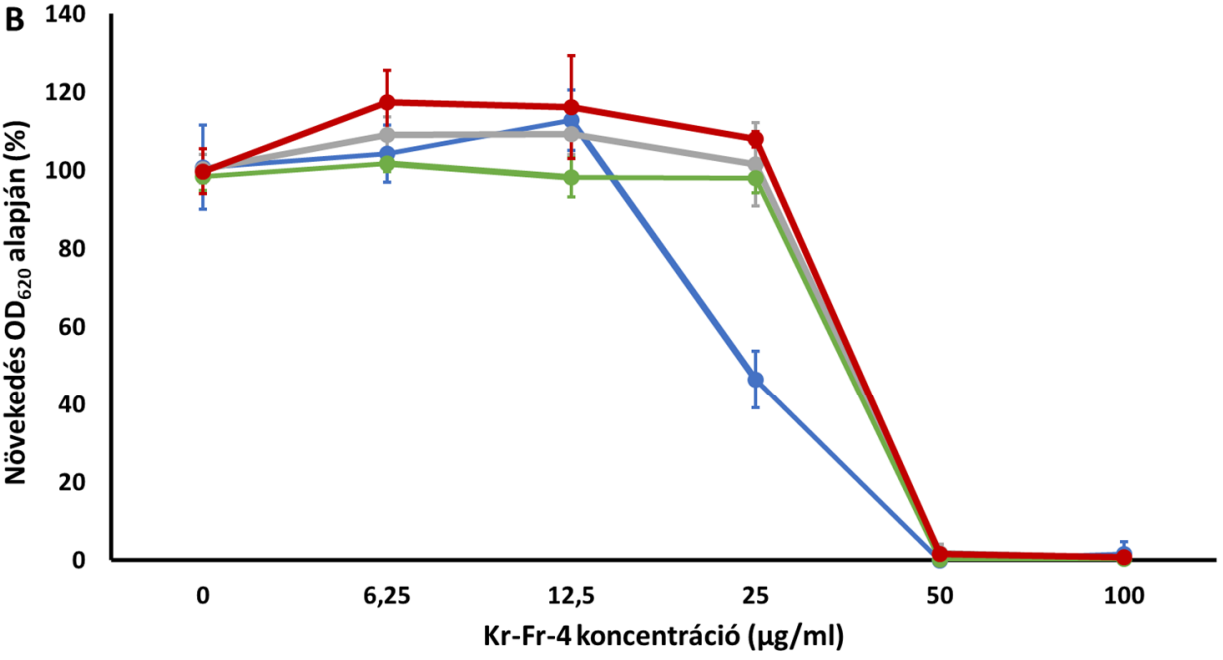

25. ábra. Az szNFAP2 Fr-2 és Fr-4 peptidfragmensek kevert aminosavsorrendü változatainak (Kr-Fr-2 (A), Kr-Fr-4 (B)) növekedésgátló hatékonysága LCM tápoldatban 48 órán át tartó, 30 C-os inkubációt követően. szNFAP2: szintetikus Neosartorya fischeri antifungális protein 2. A kezeletlen kontrollhoz $(0$ $\mu \mathrm{g} / \mathrm{ml})$ tartozó fényelnyelés mértékét vettük 100\%-os növekedésnek.

A fehérje funkcionális térképezésével feltárt peptidmotívumok megismerése lehetőséget ad a fehérjék módosított aktivitással, hatékonysággal és szelektivitással rendelkező változatainak a kifejlesztésére. Az antifungális növényi defenzinekben a konszenzus $[\mathrm{GXC}]-\left[\mathrm{X}_{3-9}\right]-[\mathrm{C}] \gamma$-core motívum jelenléte meghatározza az antimikrobiális aktivitást vagy szerkezeti szempontból funkcionális (Yount és Yeaman, 2004). Ha a $\gamma$-core 

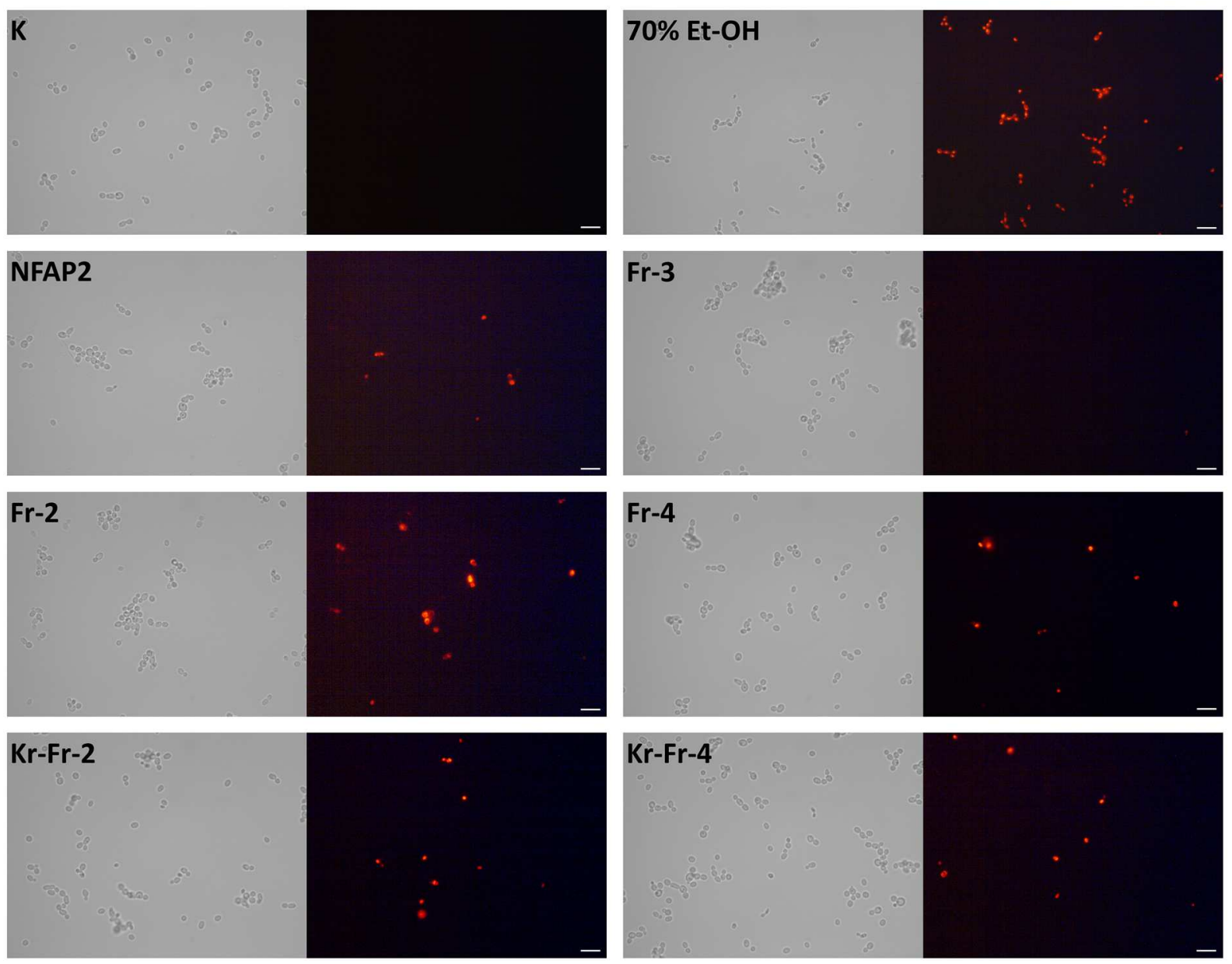

26. ábra. C. albicans ATTC 10231 sejtek PI- festődése, 10 percig, $30{ }^{\circ} \mathrm{C}$-on, minimális gátló koncentrációban alkalmazott NFAP2 és szNFAP2 peptidfragmensekkel történő kezelés után. A piros festődés membránkárosodást és sejthalált jelez. K: kezeletlen, negatív kontroll, 70\% Et-OH: pozitív PI-festési kontroll, NFAP2 és szNFAP2: natív és szintetikus Neosartorya fischeri antifungális protein 2, Fr-2 és 4: szNFAP2 2 és 4 peptidfragmens, Kr-Fr-2 és 4: szNFAP2 2 és 4 peptidfragmens kevert aminosavsorrendü változatai (10. Táblázat). Méretskála: $20 \mu \mathrm{m}$.

motívum számos hidrofil és pozitív töltésű aminosavat tartalmaz, akkor a defenzin sejtölő hatást mutat, míg a viszonylag nagy számban jelenlévő hidrofób és negatív töltésű aminosavak a molekulát a hifákon kifejtett, morfogenetikus változást indukáló hatással ruházzák fel. Érdekes módon a szintetikus növényi defenzin $\gamma$-core peptidek ugyanolyan antimikrobiális hatást mutatnak, mint a teljes hosszúságú fehérje (Sagaram és mtsi., 2011). A hidrofil és kationos antimikrobiális peptidek Candida fajokon kifejtett plazmamembrán roncsoló aktivitása már bizonyított (Nawrot és mtsi., 2013; Swidergall és Ernst, 2014). Az NFAP2 funkcionális térképezése az élesztőellenes aktivitást a molekula $N$ NNCKHKKGSGC-C N-terminális középső részéhez rendeli, nem pedig a C-terminálison jelenlévő $\gamma$-core motívumhoz ( $N$-GKCEWQGGQLNC- $C$ ). A fehérje $\gamma$-core motívumot 
tartalmazó része szinte semleges töltésü (nettó töltés pH 7,0 $=-0,2$ ) és enyhén hidrofil (GRAVY = -0,993), ellentétben az N-terminális középső résszel, ami számos pozitívan töltött (nettó töltés pH 7,0 = +3,1) és hidrofil aminosavat (GRAVY $=-1,682$ ) tartalmaz. In silico másodlagos szerkezetvizsgálatok alapján a fehérje N-terminális középső része feltekeredett harmadlagos szerkezet esetén is egy, a molekula külső részén elhelyezkedő, könnyen hozzáférhető hurokrégiót alkot (27. ábra). Ez a régió képes lehet elektrosztatikusan kapcsolódni a sejtmembrán negatívan töltött részeihez. Ez az eredmény is megerősíti az $N$ NNCKHKKGSGC-C régió valószínüsíthető szerepét az NFAP2 plazmamembrán roncsoló képességében. (27. ábra). Feltételezésünk bizonyítására további kísérletes szerkezetvizsgálatok szükségesek.

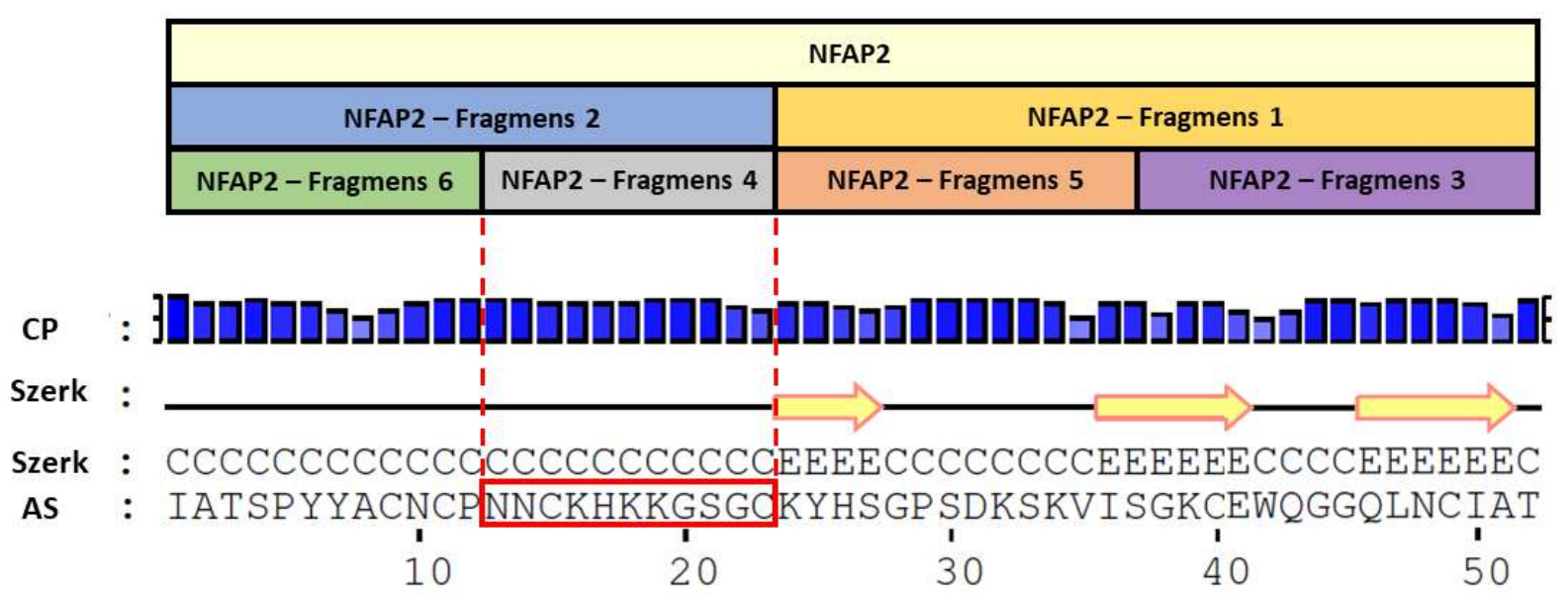

27. ábra. Az NFAP2 PSIPRED (v3.3) Protein Analysis Workbench (Buchan és mtsi., 2013) segítségével előre jelzett másodlagos szerkezete. Az antifungálisan aktív Fr-4-et, az NFAP2 feltételezett funkcionálisan aktív részét piros kerettel emeltük ki. A sárga nyíl és az „E” a $\beta$-redőt, a fekete vonal és a „C” pedig a hurokrégiót jelöli. AS: target szekvencia, CP: az adott régió analízisének a megbízhatósága aminosavakra lebontva, Szerk: feltételezett másodlagos szerkezet.

\subsection{Az NFAP2 másodlagos és harmadlagos szerkezetének vizsgálata}

\subsubsection{A rekombináns és szintetikus NFAP2 RP-HPLC analízise}

Az rNFAP2 és szNFAP2 feltekeredett szerkezetének és az NFAP2-ével megegyező diszulfid-híd mintázatának igazolására RP-HPLC analízist alkalmaztunk. A 28. ábra az rNFAP2 és szNFAP2 RP-HPLC elúciós profilját mutatja az NFAP2-vel összehasonlítva. Az analízis eredményeként az rNFAP2 és az szNFAP2 esetében ugyanazt a retenciós időt észleltük, mint a natív protein esetében, ami egyértelműen igazolja, hogy a rekombináns és 
szintetikus NFAP2 is a natívéra jellemzö feltekeredett szerkezettel és diszulfid-híd mintázattal rendelkezik (28. ábra).
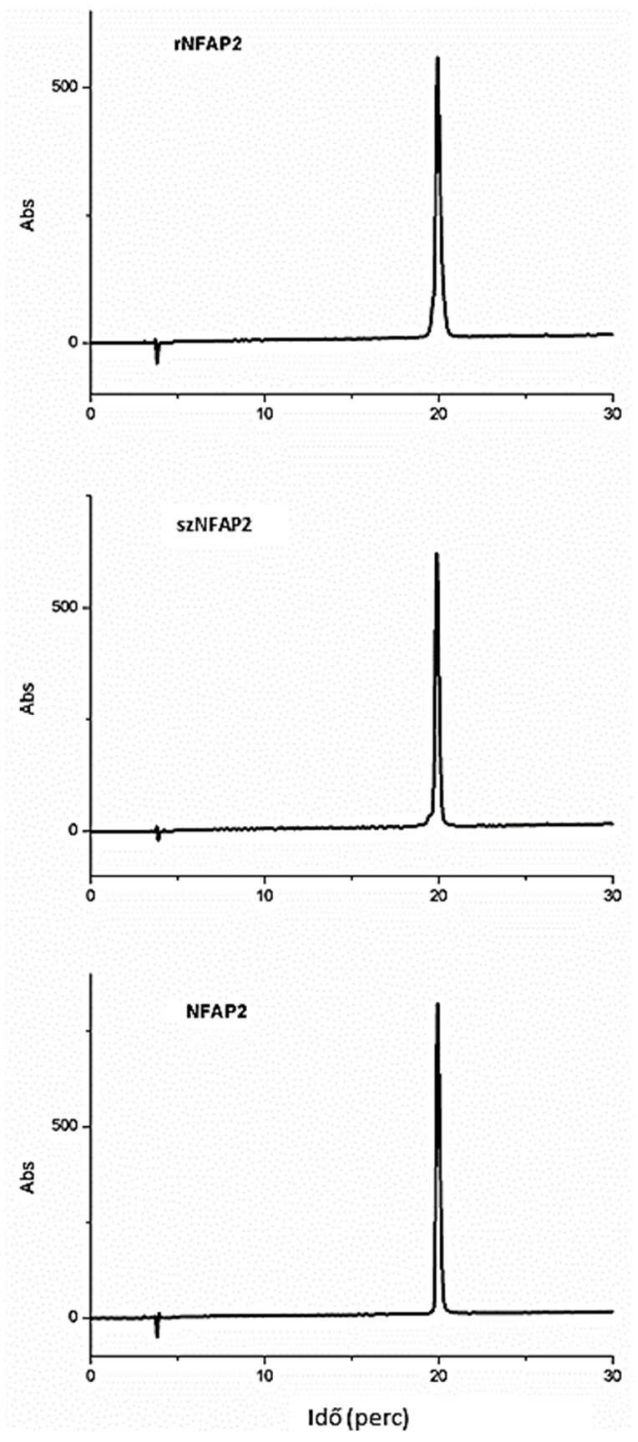

28. ábra. Az rNFAP2, szNFAP2 és NFAP2 RP-HPLC kromatogramjának összehasonlítása. NFAP2, rNFAP2 és szNFAP2: natív, rekombináns és szintetikus Neosartorya fischeri antifungális protein 2.

\subsubsection{A rekombináns és szintetikus NFAP2 szerkezetének vizsgálata ECD spektroszkópiával}

A rekombináns és szintetikus NFAP2 másodlagos szerkezeti elemeinek, diszulfidhíd mintázatának és hőstabilitásának meghatározására, az NFAP2-höz hasonlóan, ECD spektroszkópiát és termális letekeredési vizsgálatokat alkalmaztunk. Az szNFAP2-t a szintézisét követően RP-HPLC-vel tisztítottuk, így a hiteles és összehasonlítható 
eredmények eléréséhez minden, a vizsgálatba bevont fehérjét (natív NFAP2 és rNFAP2) szintén RP-HPLC-vel tovább tisztítottunk.

Az NFAP2 minták ECD spektruma nagymértékủ hasonlóságot mutatott a korábban vizsgált cgAFP-k spektrumával (Fizil, és mtsi., 2015; Galgóczy és mtsi., 2017; Garrigues és mtsi., 2017) (29. ábra). Minden esetben megfigyeltük a $\beta$-konformációra utaló pozitív és negatív csúcsot (200 nm-nél és 212 nm-nél) továbbá a diszulfid-kötésekre jellemző 228 nmnél megjelenő maximumot (29. ábra). Az ECD spektrumok alapján, az NFAP2 minták azonos másodlagos szerkezeti elemeket tartalmaznak eredettől függetlenül.
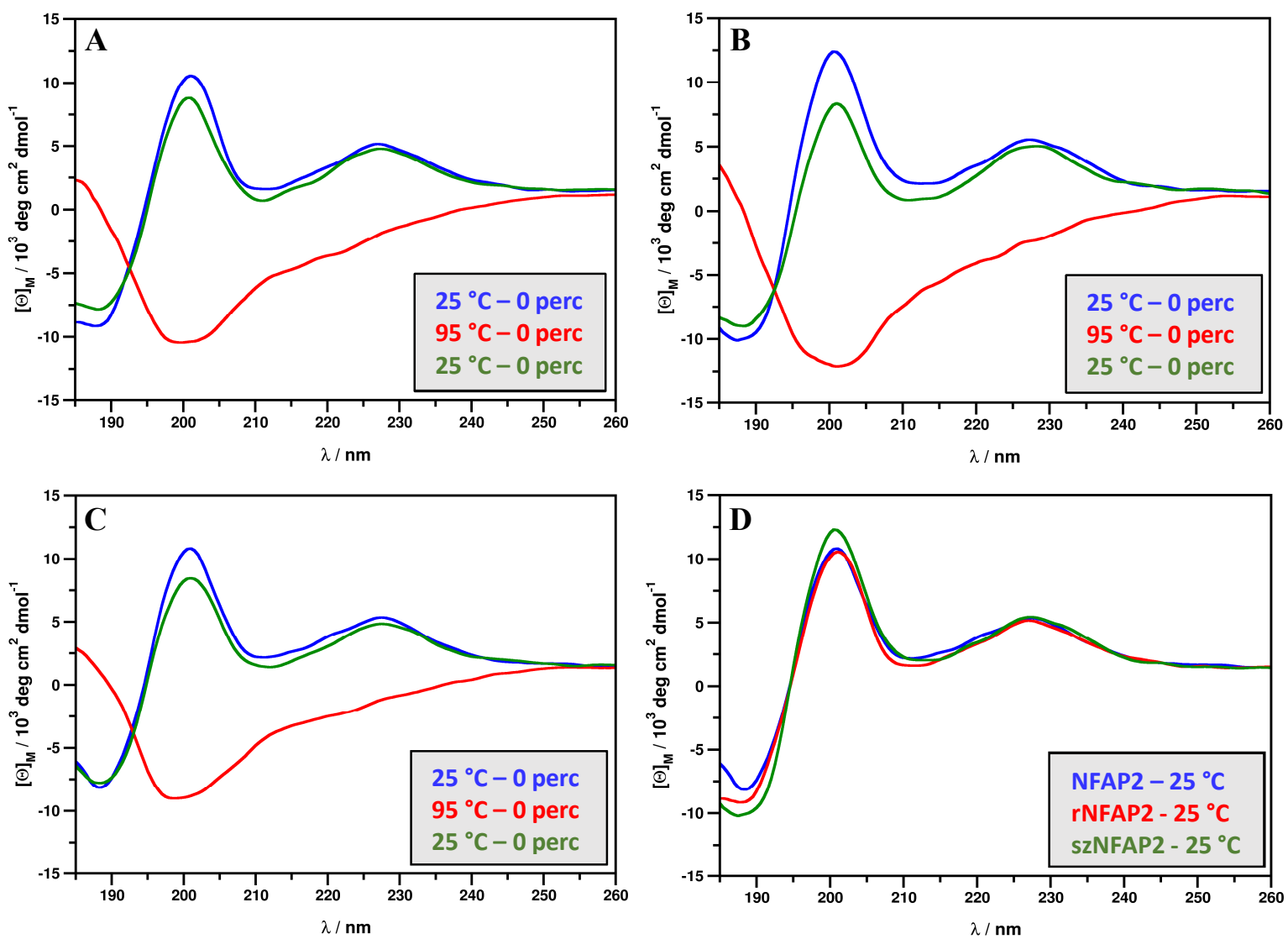

29. ábra. Az rNFAP2 (A), az szNFAP2 (B) és az NFAP2 (C) $25^{\circ} \mathrm{C}$-on (kék), $95^{\circ} \mathrm{C}$-on (piros) és a hőkezelést követően ismét $25^{\circ} \mathrm{C}-o n, 5$ perc után (zöld) rögzített ECD spektruma. Az NFAP2 (kék), rNFAP2 (piros) és szNFAP2 (zöld) $25^{\circ} \mathrm{C}$-on rögzített ECD spektrumainak illesztése (D). NFAP2, rNFAP2 és szNFAP2: natív, rekombináns és szintetikus Neosartorya fischeri antifungális protein 2.

Az ECD spektroszkópiával nyomon követett termális letekeredési vizsgálatok alapján a natív, a rekombináns és a szintetikus NFAP2 feltekeredett szerkezete $70{ }^{\circ} \mathrm{C}$-ig intakt marad és az ezután következö termális denaturáció reverzibilis (29. és 30. ábra). Ezek a megfigyelések ellentmondanak a korábbi, a nem RP-HPLC tiszta NFAP2 esetében 
tapasztaltakkal, ahol a hőkezelést követően még 4 hét után is csak mérsékelt szerkezeti visszarendeződés volt megfigyelhető (15. ábra). Feltételezéseink alapján ez az ellentmondás az eltérő módon tisztított minták (dialízis és RP-HPLC) különböző tisztaságának tulajdonítható. Az NFAP2 minták mellett, a funkcionális térképezés során használt szintetikus peptidfragmensek ECD spektrumait is rögzítettük (31. ábra), amik alapján megállapítottuk, hogy ezek a peptidfragmensek nem rendelkeznek másodlagos szerkezeti elemekkel.

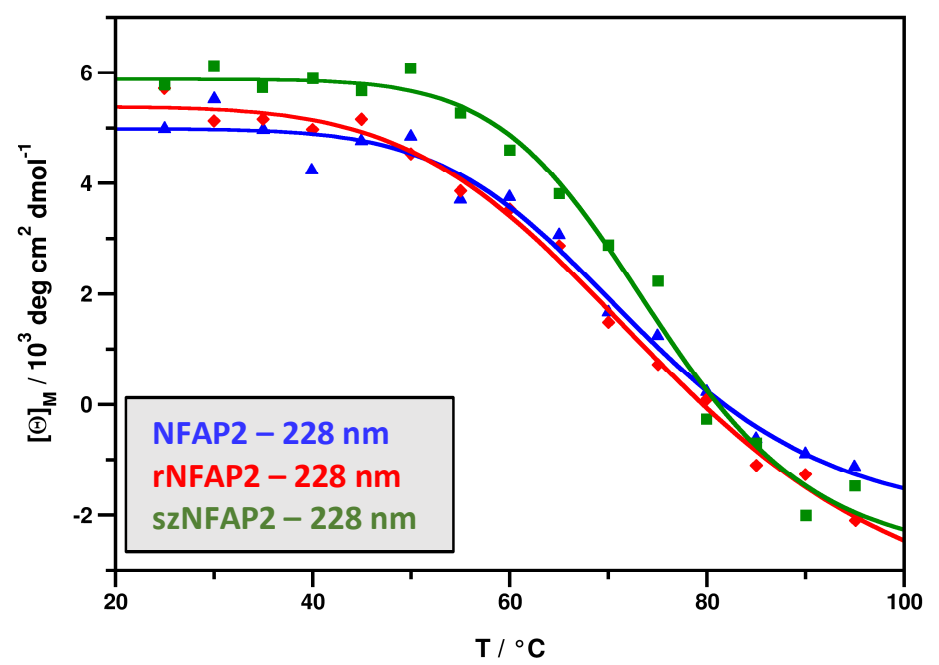

30. ábra. Az rNFAP2 (piros, $R^{2}=0,9942, T m=75,79{ }^{\circ} \mathrm{C}$ ), az szNFAP2 (zöld, $R^{2}=0,9864, T m=74,94{ }^{\circ} \mathrm{C}$ ) és az NFAP2 (kék, $R^{2}=0,9837, T m=72,92{ }^{\circ} \mathrm{C}$ ) $228 \mathrm{~nm}$-en mért termális letekeredési görbéi. NFAP2, rNFAP2 és szNFAP2: natív, rekombináns és szintetikus Neosartorya fischeri antifungális protein 2.

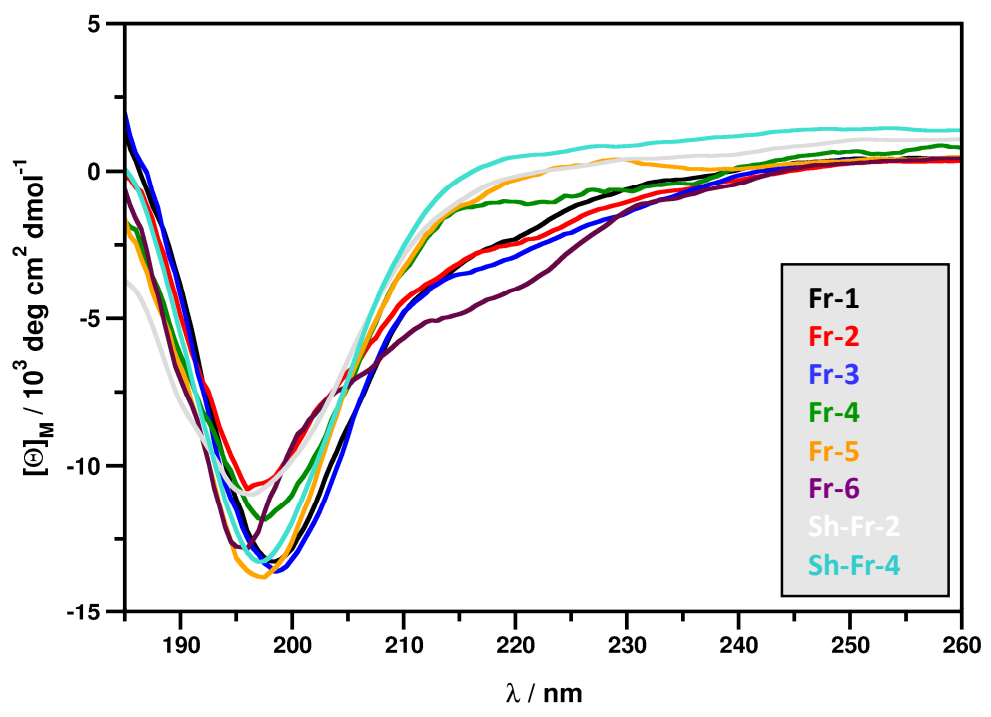

31. ábra. Az NFAP2 szintetikus peptidfragmenseinek $25^{\circ} \mathrm{C}$-on rögzített ECD spektruma. 


\subsubsection{A rekombináns és szintetikus NFAP2 NMR vizsgálata}

Az NMR vizsgálatok során a harmadlagos szerkezet és a szerkezeti dinamika nagyfelbontású vizsgálatához az izotóppal jelölt fehérjék milligrammjaira van szükség, így a natív termelö $N$. fischeri NRRL 181 által termelt és izotóppal jelölt NFAP2 elóállítása az alacsony hozam miatt nehezen kivitelezhető. Figyelembe véve az ESI-MS, RP-HPLC és ECD eredményeket, továbbá azt, hogy az szNFAP2 és az rNFAP2 a natív NFAP2-höz nagyon hasonló szerkezetet mutat, megkezdtük az elözetes NMR vizsgálatokat jelöletlen szNFAP2 és ${ }^{13} \mathrm{C} /{ }^{15} \mathrm{~N}$-jelölt rNFAP2 mintákon. A két vegyület ${ }^{13} \mathrm{C}$-HSQC típusú ujjlenyomat-spektrumának vizsgálatával megerösítettük azt az eredményt, hogy az szNFAP2 és az rNFAP2 szerkezete azonos (32. ábra). A 32. ábra „A” paneljén az szNFAP2 (kék) és rNFAP2 (piros és a jobb szemléltetés miatt a kék jelekhez képest elcsúsztatva) metil régióit tüntettük fel, míg a „B” panel az alifás $\mathrm{CH}$ régiók nagyobb tartományát mutatja. $\mathrm{Az}$ ábrákon jól látható, hogy szinte minden HSQC csúcsnak van egy párja (32. ábra). Ez a megfigyelés azt bizonyítja, hogy a két fehérje azonos felépítéssel, és nagyon hasonló feltekeredett térszerkezettel rendelkezik. Az eredmények figyelembevételével megállapíthatjuk, hogy a ${ }^{13} \mathrm{C} /{ }^{15} \mathrm{~N}$-jelölt rNFAP2 alkalmas lehet az NFAP2 feltekeredett szerkezetének és szerkezeti dinamikájának a további vizsgálatára.

A harmadlagos szerkezet pontos meghatározása az NFAP2 esetében is fontos lehet, mivel a cgAFP-k megfelelő feltekeredése elengedhetetlen a teljes antifungális hatás kiváltásához. Ez korábban az NFAP esetében már bizonyításra került, ahol is a fehérje Nterminális és a hidrofób magot alkotó aminosavakban létrehozott mutációk következtében a fehérje feltekeredése nem volt megfelelő és ezek a nem jól feltekeredett formák nem vagy csak csökkent antifungális aktivitást mutattak (Galgóczy és mtsi., 2017). Az MS mérések, az RP-HPLC analízis, az ECD és NMR spektroszkópiás vizsgálatok igazolták a rekombináns és a szintetikus NFAP2 megfelelő érését és a megfelelő antifungálisan aktív feltekeredett szerkezet kialakulását. 
A

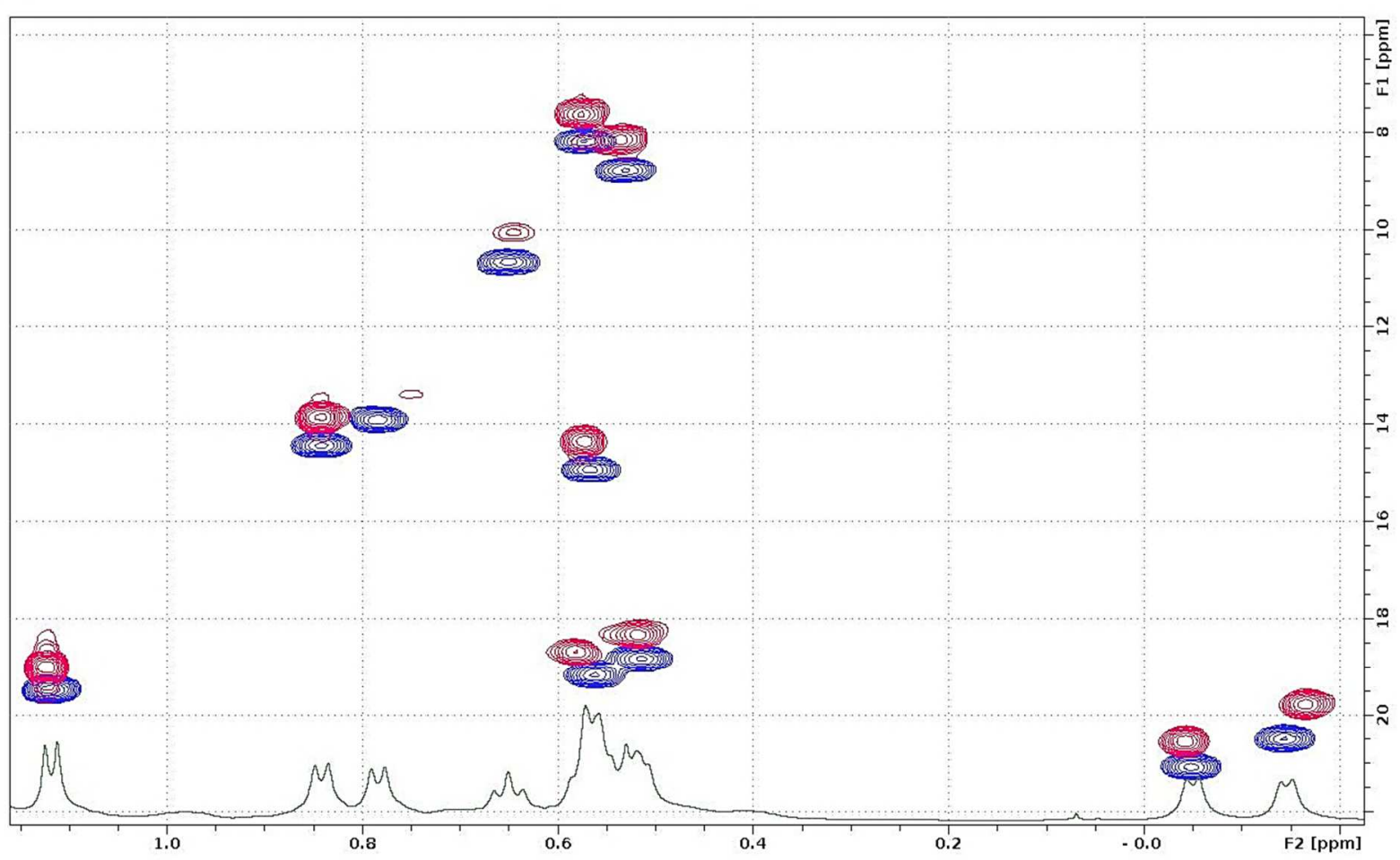

B

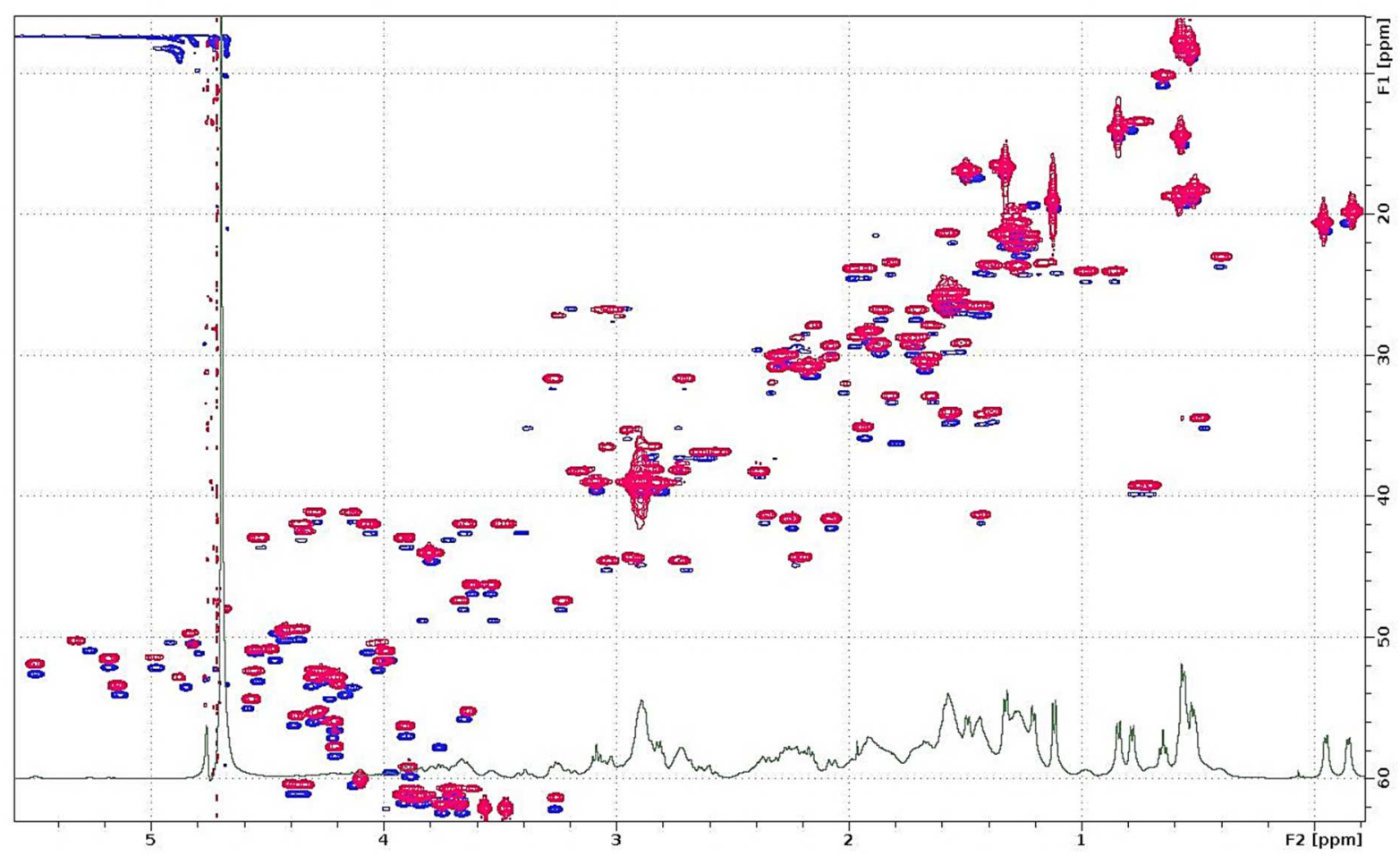

32. ábra. Az szNFAP2 (kék) és az rNFAP2 (piros) metil (A) és alifás (B) CH régiói. rNFAP2 és szNFAP2: rekombináns és szintetikus Neosartorya fischeri antifungális protein 2. 


\section{TARTALMI ÖSSZEFOGLALÓ}

Napjainkban a Candida fajok által okozott fertőzések egyre növekedő esetszámáról számolnak be világszerte. A fertőzések kezelése súlyos problémát jelent az egészségügy számára, mivel a legtöbb, jelenleg alkalmazott antifungális szer szük hatáspektrummal rendelkezik és hosszan tartó alkalmazásuk súlyos mellékhatásokkal járhat. A problémát tovább növeli az elsősorban azol, echinokandin rezisztens és multirezisztens Candida törzsek megjelenése. Mindezek alapján jelentősen megnőtt az igény új antifungális szerek kifejlesztése iránt. Az ilyen szerekkel szemben támasztott legfontosabb követelmények a következők: biztonságos alkalmazhatóság, széles hatásspektrum és gazdaságos előállíthatóság. A fonalas tömlősgombák által termelt ciszteinben gazdag fehérjék (cgAFP) megfelelhetnek ezeknek a feltételeknek, így új antifungális szerek potenciális alapjául szolgálhatnak. Gyakorlatban való alkalmazhatóságuk előfeltétele a hatásmechanizmusuk és szerkezetük megismerése, valamint a nagy mennyiségben való gazdaságos előállíthatóságuk biztosítása.

\section{Mindezek alapján a munkánk során a következő célokat tüztük ki:}

1. A Neosartorya fischeri NRRL 181 jelü izolátum által termelt élesztőellenes protein (NFAP2) izolálása, azonosítása és in silico vizsgálata.

2. Az NFAP2 filogenetikai kapcsolatainak feltárása.

3. Az NFAP2 hatékonyságának és hatásmechanizmusának tanulmányozása.

4. Az NFAP2 hőstabilitásának és szerkezetének vizsgálata.

5. Az NFAP2 nagy mennyiségben történő előállítása Penicillum chrysogenum-alapú heterológ expressziós rendszerben.

6. Az NFAP2 kémia szintézise.

7. A rekombináns és szintetikus NFAP2 antifungális hatásának vizsgálata.

8. Az NFAP2 funkcionális térképezése.

9. A rekombináns és szintetikus NFAP2 szerkezetének vizsgálata.

\section{A Neosartorya fischeri NRRL 181 jelü izolátum által termelt élesztőellenes protein} (NFAP2) izolálása, azonosítása és in silico vizsgálata

Munkánk első lépéseként a $N$. fischeri NRRL 181 fermentlevéből egy, a korábbi vizsgálatok során élesztőellenes aktivitást mutató, 5,6 kDa méretű fehérjét izoláltunk. A QTOF tömegspektrometria segítségével végzett móltömeg-mérés alapján a fehérje pontos 
monoizotópos molekulatömege 5555,4380 Da-nak adódott. Az enzimatikusan emésztett protein MS analíziséből származó tömegadatok felhasználásával elvégzett vizsgálatok eredményeként egy nem-jellemzett hipotetikus fehérjét azonosítottunk, amit Neosartorya fischeri antifungális protein 2-nek (NFAP2) neveztünk el. Az in silico vizsgálatok során kimutattuk, hogy az érett NFAP2 52 aminosavból álló, 5564,3 Da átlagos molekulatömegü, ciszteinben gazdag bázikus ( $\mathrm{pI}=9,02)$, hidrofil $(\mathrm{GRAVY}=-0,731)$ és pozitívan töltött molekula (nettó töltése $\mathrm{pH} 7,0=+5,2$ ), amit három, „abcabc” mintázatba rendeződő diszulfid-híd stabilizál.

\section{Az NFAP2 filogenetikai kapcsolatainak feltárása}

Az érett NFAP2 aminosav-szekvenciája 11-23\%-os azonosságot mutat a már izolált és jellemzett Penicillium chrysogenum antifungális protein (PAF)- és Penicillium brevicompactum DierckX bubble protein (BP)-klasztert tartalmazó cgAFP-kel. Az NFAP2 homológok keresése során a publikált Ascomycota genomokban 32 olyan fehérjeszekvenciát találtunk, amelyek nagymértékü hasonlóságot mutatnak az NFAP2-vel. A homológ NFAP2 fehérjék feltételezett érett formái 35-98\%-os azonosságot mutatnak az NFAP2 aminosav-szekvenciájával. Filogenetikai analízisünk alapján a cgAFP-k és azok feltételezett homológjai három nagy csoportot alkotnak: a PAF-klasztert, a BP-klasztert, illetve az NFAP2-klasztert hordozó fehérjék csoportját.

\section{Az NFAP2 hatékonyságának és hatásmechanizmusának tanulmányozása}

Antifungális érzékenységi vizsgálataink során az NFAP2 9 élesztőgomba és 3 fonalasgomba izolátum közül hatékonyan gátolta a 7 Candida izolátum (C. albicans ATCC 10231, C. glabrata CBS 138, C. guilliermondii CBS 566, C. krusei CBS 573, C. lusitaniae CBS 6936, C. parapsilosis CBS 604, C. tropicalis CBS 94), a Saccharomyces cerevisiae SZMC 0644 és a Schizosaccharomyces pombe SZMC 0142 növekedését dózisfüggő módon. Ugyanakkor, a fonalasgombák (Aspergillus nidulans FGSC A4, Aspergillus niger SZMC 601, Rhizomucor miehei CBS 360.92) rezisztensnek bizonyultak vele szemben. Legérzékenyebbnek a S. cerevisiae SZMC 0644 mutatkozott 24 óra inkubációt követően.

A letális és szubletális koncentrációban alkalmazott NFAP2 mid-log fázisú $S$. cerevisiae SZMC 0644 sejteken kiváltott antifungális hatásának mikroszkópos vizsgálata során a protein nem indukált apoptózist és nem okozott változást a metabolikus aktivitásban rövid időtartamon belül, viszont roncsolta a plazmamembránt. A szubletális koncentrációjú NFAP2-kezelt mintákban a PI-pozitív sejtek száma 16 órát követően szignifikánsan 
magasabb volt a kezeletlen kontrollhoz képest, míg az élesztősejtek letális koncentrációjú NFAP2-vel történő kezelése során, a kontroll és a kezelt mintákban jelenlévő piros fluoreszcenciát mutató sejtek száma között már 10 perces inkubációt követően szignifikáns különbség volt megfigyelhető.

\section{Az NFAP2 hőstabilitásának és szerkezetének vizsgálata}

Az NFAP2 oldat hőmérsékletének $25^{\circ} \mathrm{C}$-ról folyamatosan $95^{\circ} \mathrm{C}$-ra történő emelését követően az NFAP2 megőrizte a S. cerevisiae-vel szemben mutatott antifungális aktivitását, azonban a minimális gátló koncentráció (MIC) érték egy felező hígítási léptékkel növekedett.

A fehérje diszulfid-hidakkal stabilizált, kompakt szerkezetét RP-HPLC analízissel bizonyítottuk, amely során az NFAP2 a PAF-hoz hasonlóan hamar lemosódott a fordított fázisú oszlopról, ami arra utal, hogy a kompakt PAF-éval megegyező diszulfid-híd mintázattal (,abcabc”) rendelkezik. Az ECD spektroszkópiával végzett szerkezeti és hőstabil tulajdonságok vizsgálata során az NFAP2 $25^{\circ} \mathrm{C}$-on mért ECD spektruma a PAF és más, diszulfid-hidakkal stabilizált, $\beta$-szerkezetü fehérjék spektrumával megegyező tulajdonságokat mutatott. A fehérjeoldat $25{ }^{\circ} \mathrm{C}$-ra történő visszahütését követően a protein mérsékelt szerkezeti visszarendeződése volt megfigyelhető, azonban ez a visszarendeződés még négy héttel a hőkezelés után sem volt teljes. A termális letekeredési görbék alapján a protein feltekeredett szerkezete $70{ }^{\circ} \mathrm{C}$-ig sértetlen marad, azonban a termális denaturáció irreverzibilis.

\section{Az NFAP2 nagy mennyiségben történő előállítása Penicillum chrysogenum-alapú heterológ expressziós rendszerben}

Munkánk során létrehoztunk egy $P$. chrysogenum-alapú heterológ expressziós rendszert, amely lehetővé tette a rekombináns NFAP2 (rNFAP2) nagy mennyiségben történő előállítását. Az rNFAP2-kihozatal átlaga $15 \pm 1,2 \mathrm{mg} / \mathrm{l}(\mathrm{n}=2)$ volt, amely az eredeti termelő $N$. fischeri NRRL 181-gyel elérhető fehérjekihozatal negyvenszerese (368 $\pm 19 \mu \mathrm{g} / \mathrm{l}$, n=5). Az NFAP2-termelő $P$. chrysogenum fermentlevéből tisztított rNFAP2 ESI-MS analízise megerősítette, hogy a tisztított fehérje monoizotópos molekulatömege 5555,5 Da, ami megfelel az NFAP2 korábban mért monoizotópos molekulatömegének (5555,6 Da).

\section{Az NFAP2 kémiai szintézise}

Az NFAP2 további vizsgálatához szilárd fázisú peptidszintézissel létrehozott NFAP2 fragmensek natív kémiai ligációval történő összekapcsolásával szintetikus NFAP2-t 
(szNFAP2) állítottunk elő. Az szNFAP2 létrejöttét ESI-MS analízissel ellenőriztük, ami kimutatta, hogy a ligáció során kapott termék monoizotópos molekulatömege 5554,7 Da, ami megfelel a három diszulfid-hidat tartalmazó natív NFAP2 monoizotópos molekulatömegének.

\section{A rekombináns és szintetikus NFAP2 antifungális hatásának vizsgálata}

Az rNFAP2 és szNFAP2 antifungális hatásának vizsgálatába az előbbi esetében 9, míg az utóbbinál 4 élesztőgomba izolátumot vontuk be. Mind a két protein az élesztőgombák teljes növekedésgátlását okozta alacsony ionerősségü tápoldatban, és nem volt különbség a két fehérje azonos gomba izolátummal szemben meghatározott MIC értéke között, ami megegyezett a natív NFAP2 esetében megfigyeltekkel. Az rNFAP2 MIC értékeit sztenderd klinikai mikrobiológiai körülmények között (CLSI M27-A3 módszer) is meghatároztuk RPMI 1640 tápoldatban, ami során a vizsgált koncentrációtartományon belül nem minden izolátumnál figyeltünk meg teljes növekedésgátlást (C. glabrata CBS 138, C. guilliermondii CBS 566, $C$. parapsilosis CBS 604), viszont jelentős 30-50\%-os csökkenést igen $(C$. albicans ATCC 10231, C. lusitaniae CBS 6936, C. tropicalis CBS 94). Az rNFAP2 FLKval végzett kombinációs kísérlete során C. albicans (ATCC 10231) és C. parapsilosis (CBS 604) esetében a két szer között szinergista, míg C. krusei (CBS 573) esetében indifferens kölcsönhatást figyeltünk meg.

\section{Az NFAP2 funkcionális térképezése}

Az NFAP2 funkcionális térképezéséhez szilárd fázisú peptidszintézis alkalmazásával szintetikus peptidfragmenseket állítottunk elő. A két fél (Fragmens 1 és 2, Fr-1 és Fr-2) és a négy negyed (Fragmens 3-6, Fr-3-6) peptidfragmens teljes egészében lefedte az érett NFAP2 teljes szekvenciáját. A szintetikus peptidfragmensek gombaellenes hatásának in vitro mikrodilúciós tesztben elvégzett vizsgálata során csak az Fr-2 és az Fr-4 peptidfragmensek mutattak dózisfüggő, antifungális aktivitást a vizsgálatba bevont 4 élesztőgomba izolátum ellen (C. albicans ATCC 10231, C. krusei CBS 573, C. parapsilosis CBS 604, S. cerevisiae SZMC 0644), azonban magasabb MIC értékeket figyeltünk meg, mint a teljes hosszúságú NFAP2 esetében. További vizsgálatokhoz előállítottuk az Fr-2 és az Fr-4 kevert aminosavsorrendü változatait is $(\mathrm{Kr}-\mathrm{Fr}-2$ és $\mathrm{Kr}-\mathrm{Fr}-4)$ és vizsgáltuk az antifungális hatékonyságukat. Mindkét változat az Fr-2 és Fr-4 esetében megfigyelt gátló potenciált és MIC értéket mutatta. 
Az NFAP2 plazmamembrán roncsoló hatásának bizonyítására PI-festéssel vizsgáltuk az Fr-2, Fr-4, kevert változataik (Kr-Fr-4 és Kr-Fr-2) és az Fr-3 (evolúciósan konzervált $\gamma$ core régió, ami a növényi és állati antimikrobiális peptidekben és proteinekben funkcionális vagy szerkezeti szerepet játszik) C. albicans ATCC 10231 sejtekre gyakorolt hatását, összehasonlítva a teljes hosszúságú proteinnel. A MIC értéknél alkalmazott Fr-2, Fr-4 és kevert aminosavsorrendủ változataik 10 percen belül plazmamembrán roncsoló hatást fejtettek ki a sejteken, hasonlóan a szintén MIC értéknél alkalmazott natív NFAP2-höz. Ezzel szemben az NFAP2 $\gamma$-core régiót tartalmazó Fr-3 peptidfragmens nem mutatott plazmamembrán roncsoló hatást. Az eredmények alapján feltételezhetően az NFAP2 Nterminális középső régiója felelős az antifungális hatás kiváltásáért. In silico másodlagos szerkezetvizsgálatok alapján ez a régió feltekeredett harmadlagos szerkezet esetén is egy, a molekula külső részén elhelyezkedő, könnyen hozzáférhető hurkot hoz létre, ami képes lehet elektrosztatikusan kapcsolódni az érzékeny gomba sejtmembránjának negatívan töltött részeihez.

\section{A rekombináns és szintetikus NFAP2 szerkezetének vizsgálata}

Az rNFAP2 és szNFAP2 feltekeredett szerkezetének és az NFAP2-ével megegyező diszulfid-híd mintázatának igazolására alkalmazott RP-HPLC analízis eredményeként az rNFAP2 és az szNFAP2 esetében ugyanazt a retenciós időt észleltük, mint a natív protein esetében, ami egyértelmüen igazolja, hogy a rekombináns és szintetikus NFAP2 is a natívéra jellemző feltekeredett szerkezettel és diszulfid-híd mintázattal rendelkezik.

A rekombináns és szintetikus NFAP2 másodlagos szerkezeti elemeinek, diszulfidhíd mintázatának és hőstabilitásának ECD spektroszkópia segítségével történő meghatározása során az NFAP2 minták ECD spektruma nagymértékü hasonlóságot mutatott a korábban vizsgált cgAFP-k spektrumához, ami alapján a fehérjék azonos másodlagos szerkezeti elemeket tartalmaznak eredettől függetlenül. Ezzel ellentétben a funkcionális térképezés során használt szintetikus peptidfragmensek ECD spektroszkópiás vizsgálata során megállapítottuk, hogy a fragmensek nem rendelkeznek másodlagos szerkezeti elemekkel. A termális letekeredési vizsgálatok alapján a natív, a rekombináns és a szintetikus NFAP2 natív feltekeredett szerkezete $70{ }^{\circ} \mathrm{C}$-ig intakt marad, és az ezután következő termális denaturáció reverzibilis.

A harmadlagos szerkezet és a szerkezeti dinamika nagyfelbontású vizsgálatához az elözetes NMR analízis során jelöletlen szNFAP2 és ${ }^{13} \mathrm{C} /{ }^{15} \mathrm{~N}$-jelölt $\mathrm{rNFAP} 2$ mintákat 
használtunk. A két vegyület ${ }^{13} \mathrm{C}$-HSQC típusú ujjlenyomat-spektrumának vizsgálata alapján a két fehérje azonos felépítéssel és nagyon hasonló, feltekeredett térszerkezettel rendelkezik.

Munkánk növeli bővíti az izolált és jellemzett cgAFP-k csoportjainak számát. Az általunk megfigyelt tulajdonságai alapján az NFAP2 ígéretes jelölt lehet gyakorlati célú felhasználásra, továbbá antifungális spektrumának, pontos hatásmódjának és a szerkezethatás összefüggésének megismerése után új szintetikus antifungális protein-analógok alapjául szolgálhat. 


\section{ANGOL NYELVÜ ÖSSZEFOGLALÓ (SUMMARY)}

In the last three decades, systemic fungal infections caused by different Candida spp. have become one of the most frequent healthcare-associated infections showing an increasing trend worldwide. The treatment is problematic because the currently used antifungal agents have narrow spectrum and can cause serious side-effects. A trend in resistance due to the misuse of antifungal drugs, especially azoles and echinocandins is recently reported moreover multidrug resistant strains are also occurring. There is therefore an urgent need to reduce the application of routinely administrated antifungal drugs by introducing novel, alternative agents and therapeutic strategies (e.g. drug combinatory therapy). Naturally occurring peptides, proteins and their synthetic derivatives with antifungal activity have been proposed as a potential source and templates of novel drugs to treat mycotic infections. The small, cysteine-rich and cationic antifungal proteins of filametous ascomycetes have antifungal activity on several opportunistic human pathogenic filamentous fungi. Based on in vitro and in vivo interaction and toxicological studies the members of this protein group represent exceptionally suitable compounds of commercial drugs against fungi and offer an alternative, safely applicable solution for recent antifungal challenges in the human health.

\section{The aims of the present study were the followings:}

1. Isolation, identification and investigation of in silico structure of an anti-yeast protein secreted by Neosartorya fischeri NRRL 181 isolate (NFAP2).

2. Investigation of the phylogenetic relationships of NFAP2.

3. Examination of the in vitro antifungal activity and antifungal mechanism of NFAP2.

4. Investigation of heat stability and structure of NFAP2.

5. Heterologous expression and bulk production of NFAP2 by Penicillum chrysogenum.

6. Chemical synthesis of NFAP2.

7. Investigation the antifungal activity of synthetic and recombinant NFAP2.

8. Functional mapping of NFAP2.

9. Structural investigation of recombinant and synthetic NFAP2. 


\section{Isolation, identification and investigation of in silico structure of an anti-yeast protein secreted by Neosartorya fischeri NRRL 181 isolate (NFAP2)}

At first, we isolated and identified a $\sim 5.6 \mathrm{kDa}$ antifungal protein with high anti-yeast activity from the supernatant of $N$. fischeri NRRL 181 cultivated in a minimal medium. Based on mass spectrometric measurement, the monoisotopic molecular mass of this protein was 5555.5513 Da. Using the processed data from MS analysis of enzymatic digested NFAP2 we identified an uncharacterized, hypothetical protein that was termed as Neosartorya fischeri antifungal protein 2 (NFAP2).

Based on in silico investigations, the low molecular mass (average: $5564.3 \mathrm{Da}$ ), extracellular, cationic $(\mathrm{pI}=9.02)$, and cysteine-rich mature NFAP2 consists of 52 amino acid residues. The six cysteines form three intramolecular disulfide bridges showing " $a b c a b c$ " bounding pattern. Furthermore, the NFAP2 is a hydrophilic (Grand Average of Hydropathy Value, GRAVY $=-0.731$ ) and positively charged (net charge at $\mathrm{pH} 7.0=+5.2$ ) molecule.

\section{Investigation of the phylogenetic relationships of NFAP2}

The amino acid sequence of mature NFAP2 shows $11-23 \%$ identity to the isolated Penicillium chrysogenum antifungal protein (PAF)- and Penicillium brevicompactum DierckX bubble protein (BP)-cluster proteins from filamentous Ascomycetes. BLAST searches yielded 32 protein sequences with significant similarity to NAFP2 in published Ascomycota genomes. The predicted mature forms of these putative proteins show $35-98 \%$ amino acid identity to NFAP2. Based on a phylogenetic analysis, NFAP2 and its putative homologs represent a new group of ascomycetous cysteine-rich antifungal proteins beside the described PAF- and BP-cluster proteins.

\section{Examination of the in vitro antifungal activity and antifungal mechanism of NFAP2}

The minimal inhibitory concentration (MIC) of NFAP2 for yeasts were in the range of $0.195-1.563 \mu \mathrm{g} / \mathrm{ml}$, where Saccharomyces cerevisiae proved to be the most (MIC: 0.195 $\mu \mathrm{g} / \mathrm{ml}$ ), and Candida krusei the least (MIC: $1.563 \mu \mathrm{g} / \mathrm{ml}$ ) susceptible in low cationic medium. MIC values varied between $0.391-1.563 \mu \mathrm{g} / \mathrm{ml}$ for clinically relevant Candida species, after 24 hours of incubation.

The manifestation of antifungal mechanism of NFAP2 on S. cerevisiae cells was investigated at its sublethal $(1.56 \mu \mathrm{g} / \mathrm{ml})$ and lethal $(0.195 \mu \mathrm{g} / \mathrm{ml})$ concentrations measured after 24 hours of incubation. Physiological changes in cells in the presence of an antifungal can be investigated at its sublethal concentrations which do not kill the fungus. 
The two-colour fluorescent FUN1 stains the cytoplasm and metabolically inactive vacuoles green, while the metabolically active ones red. Based on the proportion of the red and green vacuoles between the treated and untreated samples, change in the metabolic activity of $S$. cerevisiae was not detected in the presence of sublethal NFAP2 concentration even after 16 hours-long NFAP2 treatment.

Annexin V-FITC Apoptosis Detection Kit (Sigma-Aldrich) dyes the apoptotic cells green, while the necrotic cells are counterstained red by the membrane impermeant, redfluorescent nuclear and chromosome stain propidium iodide (PI), and living cells do not show any fluorescence. There was no significant difference between the proportion of green cells in the NFAP2-treated and untreated samples even after 16 hours. In short exposure time $(10,30$ and 60 minutes) at sublethal NFAP2 concentration, same percent of the cells was counterstained with PI in the treated and untreated samples (ca. one percent of the total cell number), but after 16 hours of incubation though three times more red cells were counted in the treated sample than in the untreated control reaching a statistically significant difference $(\mathrm{p}=0.00004)$. Based on this last observation we suggested that NFAP2 cannot induce apoptosis in the yeast cells, but can disrupt the plasma membrane that was verified with a simple PI-staining.

After six hours of exposure to sublethal NFAP2 concentration, same percent of the total cell number showed red fluorescence as in the untreated control. In contrast to this, after 16 hours six percent of the total cell number were PI-positive in the untreated control compared to the sample treated with sublethal concentration of NFAP2 where it was $18 \%$. When the cells were exposed to lethal concentration of NFAP2, significant differences were observed in the number of PI-positive cells between the NFAP2-treated sample and the untreated control already after 10 minutes of incubation. After 16 hours, viable cells were not observed in the NFAP2-treated sample.

\section{Investigation of heat stability and structure of NFAP2}

After continuous heating and five minutes exposure to $95^{\circ} \mathrm{C}, \mathrm{NFAP} 2$ maintained its antifungal activity against $S$. cerevisiae with a one dilution step shift in the 24 hours MIC from $0.195 \mu \mathrm{g} / \mathrm{ml}$ to $0.391 \mu \mathrm{g} / \mathrm{ml}$.

To prove disulfide bond-stabilized compact tertiary structure of NFAP2 we applied a reversed-phase high performance liquid chromatography (RP-HPLC) method. Considering that NFAP2 eluted from the reversed-phase column as early as naturally folded PAF, the 
same interlocking disulfide bond pattern to it ("abcabc") seems to be the most probable for NFAP2.

Electronic circular dichroism (ECD) spectrum of NFAP2 at $25{ }^{\circ} \mathrm{C}$ shows features similar to spectra of the homologous PAF protein and other disulfide bridged, $\beta$-structured proteins. After the cooling of NFAP2 solution back to $25{ }^{\circ} \mathrm{C}$ moderate structural reorganization takes place, but this reorganization is incomplete even four weeks after the annealing. Based on thermal unfolding curves, the native fold remains intact up to $70{ }^{\circ} \mathrm{C}$, although thermal denaturation is irreversible.

\section{Heterologous expression and bulk production of NFAP2 by Penicillum chrysogenum}

The generated $P$. chrysogenum $\Delta$ paf/nfap2 strain produced recombinant NFAP2 (rNFAP2). After purification to homogeneity, only one protein band was detected by SDSPAGE at the molecular weight of the native NFAP2 (nNFAP2). Electrospray ionization mass spectrometry (ESI-MS) analysis confirmed that the monoisotopic molecular mass of this protein $(5555.5 \mathrm{Da})$ corresponds well to the previously detected monoisotopic molecular mass $(5555.6 \mathrm{Da})$ of nNFAP2 produced by $N$. fischeri NRRL 181 . This result clearly indicated the heterologous production of correctly processed NFAP2 with three intramolecular disulfide bonds between the six cysteine residues. The final NFAP2 yield was $15 \pm 1.2 \mathrm{mg} / \mathrm{l}(\mathrm{n}=2)$ compared to the native producer $N$. fischeri NRRL 181 where it was ony $368 \pm 19 \mu \mathrm{g} / \mathrm{l}$.

\section{Chemical synthesis of NFAP2}

Peptide fragments of NFAP2 were prepared using manual solid-phase peptide synthesis and either Boc or Fmoc chemistry applying N,N'-dicyclohexylcarbodiimide / 1Hbenzotriazol-1-ol hydrate (DCC/HOBt) coupling. For the chemical synthesis of NFAP2, the C-terminal half of the protein (Fragment 1) was prepared, and in addition to this, the Nterminal half of the protein was synthesized in thioester form (Fragment 2t, Fr-2t) to allow native chemical ligation with Fragment 1. Cysteine thiols of the ligation products were oxidized to disulfide bridges with glutathione redox buffer having the glutathione:glutathione disulfide (GSH:GSSG) ratio of 1:1. ESI-MS analysis revealed the expected molecular mass for synthetic NFAP2 (sNFAP2), having three intramolecular disulfide bonds (5554.7 Da). 


\section{Investigation of antifungal activity of synthetic and recombinant NFAP2}

Native, recombinant and synthetic forms of NFAP2 totally inhibited the yeast growth after 48 hours in their investigated concentration range in low cationic medium, and there was no difference between their MICs. The MICs varied in the range of $1.56-12.5 \mu \mathrm{g} / \mathrm{ml}$ depending on the investigated species. Both the recombinant and the native forms of NFAP2 showed dose-dependent antifungal activity. These results propose the potential clinical applicability of the high-yield produced rNFAP2.

To determine MICs of rNFAP2 under standardized clinical microbiological conditions, its in vitro antifungal activity was investigated against human pathogenic Candida spp. in human serum mimicking RPMI 1640 medium based on the recommendation of Clinical and Laboratory Standards Institute-M27A3 susceptibility test method. $C$. albicans ATCC 10231, C. krusei CBS 573, C. lusitaniae CBS 6936, and C. tropicalis CBS 94 showed higher MICs than $100 \mu \mathrm{g} / \mathrm{ml}$; however, this applied dosage could decrease the fungal growth to $30 \%$ and $50 \%$ except of C. krusei CBS 573. The growth of C. glabrata CBS 138, C. guilliermondii CBS 566, and C. parapsilosis CBS 604 was totally inhibited in the investigated concentration range with MICs of 12.5, 3.125, and $100 \mu \mathrm{g} / \mathrm{ml}$, respectively. These results sign the limited clinical applicability of NFAP2 as systemic monotherapeutic antifungal drug, thus its effectivity in combinatorial drug application was investigated.

C. albicans ATCC 10231, C. parapsilosis CBS 604, and C. krusei CBS 573 were involved in the interaction tests of NFAP2 with fluconazole (FLC). To calculate the fractional inhibitory concentration index (FICI) to reveal the type of interaction, exact MICs of NFAP2 and FLC were determined a proved to be $200 \mu \mathrm{g} / \mathrm{ml}$ and $400 \mu \mathrm{g} / \mathrm{ml}$ for C. albicans ATCC 10231 and C. krusei CBS 573, respectively. Co-administration of NFAP2 and FLC showed synergistic interactions $(\mathrm{FICI}=0.28$ and 0.19) against $C$. albicans ATCC 10231 and C. parapsilosis CBS 604, while it was indifferent $(\mathrm{FICI}=0.52)$ to C. krusei CBS 573.

\section{Functional mapping of NFAP2}

Peptide motifs derived from a full-length antifungal protein allow the identification of putative antimicrobially active motifs. Considering this approach, we involved six synthetic peptide fragments of NFAP2 (Fragments 1-6; Fr 1-6) in antifungal activity assays to reveal its functionally active site(s). Solid-phase peptide synthesis was applied to prepare peptide fragments of NFAP2. Two halves (Fr-1 and Fr-2) and four quarters (Fr-3-6) were synthesized on a solid support applying either Boc or Fmoc chemistry. Besides this, shuffle variants of Fragments 2 and 4 (Sh-Fr-2 and Sh-Fr-4) were prepared using the same method. 
In LCM, only Fr-2 and Fr-4 showed dose-dependent antifungal activity, and their MICs were higher than the full-length NFAP2. At their MICs they exerted the prompt plasma membrane disruption effect on C. albicans what we already observed at NFAP2 by applying PI staining. Taking into account that the Fr-4 is the C-terminal part of the Fr-2, and the Nterminal Fr-6 part of Fr-2 did not show antifungal activity, we assume that the mid-Nterminal part of the protein (Fr-4) influences the antifungal activity.

Previous studies demonstrated that synthetic peptide fragments of antifungal proteins and their rational-designed variants show remarkable inhibitory potential on fungi if they are hydrophilic and have high positive net-charge. Considering this, we were curious whether the observed antifungal activity of Fr-2 and Fr-4 depends on these features or the primary structure determines it. Hence, we also involved the shuffle variants of these two peptides (Sh-Fr-2 and Sh-Fr-4) in antifungal activity assays. Both shuffle variants showed the same inhibitory potential as Fr-2 and Fr-4, and the prompt plasma membrane disruption effect resulting in the conclusion that the antifungal activity of NFAP2 rather depends on the net charge and hydrophilicity of mid-N-terminal region than on its primary structure.

The C-terminal part of NFAP2 contains the consensus $\gamma$-core motif [GXC]-[X 3 3-9][C], which is important for the activity or folding of antifungal proteins in animals, humans, and antifungal plant defensins. Interestingly, the peptide fragment containing the $\gamma$-core motif of NFAP2 ( $N$-GKCEWQGGQLNC-C) (Fr-3) was inactive against yeasts, and did not have plasma membrane disruption ability assuming that this specific motif alone has no antiyeast function, but presumably needs the structural-functional support from other parts of NFAP2.

\section{Structural investigation of recombinant and synthetic NFAP2}

Formation of interlocking disulfide bridges characteristic for small, cysteine-rich antifungal proteins of filamentous ascomycetes results in decreased retention time on a reversed-phase column. RP-HPLC revealed the same retention time for the RNAP2 and SNFAP2 as for the native one confirming right pairing of cysteines and native fold of the recombinant and synthetic proteins.

ECD spectra of all NFAP2 samples show features highly similar to that reported earlier for this class of proteins, with contributions emerging from $\beta$-conformation $(200 \mathrm{~nm}$, $212 \mathrm{~nm})$ and disulfide bridges (228 nm). In fact, all NFAP2 samples are demonstrated to possess identical secondary structural elements regardless of their native, recombinant or synthetic origin. Thermal unfolding experiments followed by ECD indicated, that the native 
folds of NFAP2, rNFAP2 and SNFAP2 remain intact up to approximately $70{ }^{\circ} \mathrm{C}$, and thermal denaturation is reversible. This contradicts previous observations taken for nNFAP2 samples purified by dialysis, where only partial structural reorganization was observed even four weeks after the annealing. This discrepancy may be attributed to higher integrity of samples purified by RP-HPLC as opposed to those purified by dialysis.

The preliminary nucleic magnetic resonance investigations were started with unlabelled sNFAP2 and ${ }^{13} \mathrm{C} /{ }^{15} \mathrm{~N}$-labelled rNFAP2. First, we confirmed the structure identity of sNFAP2 and rNFAP2 using the ${ }^{13} \mathrm{C}$-heteronuclear single quantum coherence (HSQC) type fingerprint spectra of the two compounds. Though the signal intensities are diverse due to different relaxation behaviour and the constant-time version of HSQC experiment necessary to remove ${ }^{13} \mathrm{C}-{ }^{13} \mathrm{C}$ couplings in the rNFAP2, it can be seen that nearly all HSQC peaks have a pair, a closest neighbour in the map. This observation strongly suggests that the two compounds have identical constitution and even more very similar, folded spatial structure.

Summarizing, our results significantly contribute to the application of NFAP2 and its peptide derivatives as economic and easily-producible antifungal agents in the therapy of Candida infections; and they represent the first steps to reveal the tertiary structure and functional active sites for rational design of novel NFAP2-based antimicrobial proteins. 


\section{IRODALOMJEGYZÉK}

Abad, L.R.; D'Urzo, M.P.; Narasimhan, M.L.; Reuveni, M.; Zhu, J.K.; Niu, X. és mtsi. (1996). "Antifungal activity of tobacco osmotin has specificity and involves plasma membrane permeabilization." Plant Sci 118:11-23.

Arendrup, M.C. és Perlin, D.S. (2014). "Echinocandin resistance: an emerging clinical problem?" Curr Opin Infect Dis 27:484-492.

Bailly, S.; Maubon, D.; Fournier, P.; Pelloux, H.; Schwebel, C.; Chapuis, C. és mtsi. (2016). "Impact of antifungal prescription on relative distribution and susceptibility of Candida spp. - Trends over 10 years." J Infect 72:103-111.

Balashov, S.V.; Park, S. és Perlin, D.S. (2006). "Assessing resistance to the echinocandin antifungal drug caspofungin in Candida albicans by profiling mutations in FKS1." Antimicrob Agents Chemother 50:2058-2063.

Barna, B.; Leiter, E.; Hegedűs, N.; Bíró, T. és Pócsi, I. (2008). "Effect of the Penicillium chrysogenum antifungal protein (PAF) on barley powdery mildew and wheat leaf rust pathogens." J Basic Microbiol 48:516-520.

Bates, D.W.; Su, L.; Yu, D.T.; Chertow, G.M.; Seger, D.L. és Platt, R. (2001). "Mortality and costs of acute renal failure associated with amphotericin B therapy." Clin Infect Dis 32:686-693.

Batta, G.; Barna, T.; Gáspári, Z.; Sándor, S.; Kövér, K.E.; Binder, U. és mtsi. (2009). "Functional aspects of the solution structure and dynamics of PAF - a highly-stable antifungal protein from Penicillium chrysogenum." FEBS J 276:2875-2890.

Binder, U.; Oberparleiter, C.; Meyer, V. és Marx, F. (2010). "The antifungal protein PAF interferes with PKC/MPK and cAMP/PKA signalling of Aspergillus nidulans." Mol Microbiol 75:294-307.

Binder, U.; Bencina, M.; Eigentler, A.; Meyer, V. és Marx, F. (2011). "The Aspergillus giganteus antifungal protein $\mathrm{AFP}_{\mathrm{NN} 5353}$ activates the cell wall integrity pathway and perturbs calcium homeostasis." BMC Microbiol 11:209.

Borchsenius, F. (2009). FastGap 1.2. http://www.aubot.dk/FastGap home.htm.

Bouza, E. és Muñoz, P. (2008). "Epidemiology of candidemia in intensive care units." Int J Antimicrob Agents 32:S87-S91.

Brown, G.D.; Denning, D.W.; Gow, N.A.; Levitz, S.M.; Netea, M.G. and White, T.C. (2012). "Hidden killers: human fungal infections." Sci Transl Med 4:165rv13.

Buchan, D.W.A.; Minneci, F.; Nugent, T.C.O.; Bryson, K. és Jones, D.T. (2013). "Scalable web services for the PSIPRED Protein Analysis Workbench." Nucleic Acids Res 41:340348.

Campos-Olivas, R.; Bruix, M.; Santoro, J.; Lacadena, J.; Martinez del Pozo, A.; Gavilanes, J.G. és Rico, M. (1995). "NMR solution structure of the antifungal protein from Aspergillus giganteus: evidence for cysteine pairing isomerism." Biochemistry 34:30093021.

Ceroni, A.; Passerini, A.; Vullo, A. és Frasconi, P. (2006). "DISULFIND: a disulfide bonding state and cysteine connectivity prediction server." Nucleic Acids Res 34:177181.

Chen, Z.; Ao, J.; Yang, W.; Jiao, L.; Zheng, T. és Chen, X. (2013). "Purification and characterization of a novel antifungal protein secreted by Penicillium chrysogenum from an Arctic sediment." Appl Microbiol Biotechnol 97:10381-10390.

Clinical and Laboratory Standards Institute (2008). "Reference method for broth dilution antifungal susceptibility testing of yeasts." Approved standard-third edition. CLSI document M27-A3 (CLSI, Wayne, PA, USA). 
Cociancich, S.; Ghazi, A.; Hetru, C.; Hoffmann, J.A. és Letellier, L. (1993). "Insect defensin, an inducible antibacterial peptide, forms voltage-dependent channels in Micrococcus luteus." J Biol Chem 268:19239-19245.

Cohen, E. (2001). "Chitin synthesis and inhibition." Pest Manag Sci 57:946-950.

Cota, J.M.; Grabinski, J.L.; Talbert, R.L.; Burgess, D.S.; Rogers, P.D.; Edlind, T.D. és Wiederhold, N.P. (2008). " Increases in SLT2 expression and chitin content are associated with incomplete killing of Candida glabrata by caspofungin." Antimicrob Agents Chemother 52:1144-1146.

Cowen, L.E.; Sanglard, D.; Howard, S.J.; Rogers, P.D. és Perlin, D.S. (2015). "Mechanisms of antifungal drug resistance." Cold Spring Harb Perspect Med 5:a019752.

Das, I.; Nightingale, P.; Patel, M. és Jumaa, P. (2011). "Epidemiology, clinical characteristics, and outcome of candidemia: experience in a tertiary referral center in the UK." Int J Infect Dis 15:e759-763.

Day, J.N.; Chau, T.T.; Wolbers, M.; Mai, P.P.; Dung, N.T.; Mai, N.H. és mtsi. (2013). "Combination antifungal therapy for cryptococcal meningitis." N Engl J Med 368:12911302.

Delgado, J.; Acosta, R.; Rodríguez-Martín, A.; Bermúdez, E.; Núñez, F. és Asensio, M.A. (2015). "Growth inhibition and stability of PgAFP from Penicillium chrysogenum against fungi common on dry-ripened meat products." Int J Food Microbiol 205:23-29.

del Pozo, Á.M.; Lacadena, V.; Mancheno, J.M.; Olmo, N.; Onaderra, M. és Gavilanes, J.G. (2002). "The antifungal protein AFP of Aspergillus giganteus is an oligonucleotide/oligosaccharide binding (OB) fold-containing protein that produces condensation of DNA." J Biol Chem 277:46179-46183.

Demain, A.L. és Vaishnav, P. (2009). "Production of recombinant proteins by microbes and higher organism." Biotechnol Adv 27:297-306.

Denning, D.W. (2003). "Echinocandin antifungal drugs." Lancet 362:1142-1151.

Díez, B.; Mellado, E.; Rodríguez, M.; Bernasconi, E. és Barredo, J.L. (1999). "The NADPdependent glutamate dehydrogenase gene from Penicillium chrysogenum and the construction of expression vectors for filamentous fungi." Appl Microbiol Biotechnol 52:196-207.

Eder, J. és Fersht, A.R. (1995). "Pro-sequence-assisted protein folding." Mol Microbiol 16:609-614.

Edwards, S.G. (2004). "Influence of agricultural practices on fusarium infection of cereals and subsequent contamination of grain by trichothecene mycotoxins." Toxicol Lett 153:29-35.

Eliopoulos, G.M. és Moellering, R.C. (1996). "Antimicrobial combinations." In: Lorian, V. (szerk.) Antibiotics in Laboratory Medicine. The Williams and Wilkins Co., 4th ed. Baltimore, Md. 330-396.

Falagas, M.E.; Roussos, N. és Vardakas, K.Z. (2010). "Relative frequency of albicans and the various non-albicans Candida spp among candidemia isolates from inpatients in various parts of the world: a systematic review." Int J Infect Dis 14:e954-e966.

Favel, A.; Michel-Nguyen, A.; Peyron, F.; Martin, C.; Thomachot, L.; Datry, A. és mtsi. (2003). "Colony morphology switching of Candida lusitaniae and acquisition of multidrug resistance during treatment of a renal infection in a newborn: case report and review of the literature." Diagn Microbiol Infect Dis 47:331-339.

Fizil, A.; Gáspári, Z.; Barna, T.; Marx, F. és Batta, G. (2015). "'Invisible" conformers of an antifungal disulfide protein revealed by constrained cold and heat unfolding, CEST-NMR experiments, and molecular dynamics calculations." Chemistry 23:5136-5144. 
Galgóczy, L.; Papp, T.; Leiter, E.; Marx, F.; Pócsi, I. és Vágvölgyi, C. (2005). "Sensitivity of different Zygomycetes to the Penicillium chrysogenum antifungal protein (PAF)." J Basic Microbiol 45:136-141.

Galgóczy, L.; Papp, T.; Lukács, G.; Leiter, E.; Pócsi, I. és Vágvölgyi, C. (2007). "Interactions between statins and Penicillium chrysogenum antifungal protein (PAF) to inhibit the germination of sporangiospores of different sensitive Zygomycetes." FEMS Microbiol Lett 270:109-115.

Galgóczy, L.; Papp, T.; Pócsi, I.; Hegedűs, N. és Vágvölgyi, C. (2008). "In vitro activity of Penicillium chrysogenum antifungal protein (PAF) and its combination with fluconazole against different dermatophytes." Anton Leeuw Int J G 94:463-470.

Galgóczy, L.; Kovács, L. és Vágvölgyi, C. (2010). "Defensin-like antifungal proteins secreted by filamentous fungi." Current Research, Technology and Education Topics in Applied Microbilogy an Microbial Biotechnology 1:550-559.

Galgóczy, L.; Virágh, M.; Kovács, L.; Tóth, B.; Papp, T. és Vágvölgyi, C. (2013a). "Antifungal peptides homologous to the Penicillium chrysogenum antifungal protein (PAF) are widespread among Fusaria." Peptides 39:131-137.

Galgóczy, L.; Kovács, L.; Karácsony, Z.; Virágh, M.; Hamari, Z. és Vágvölgyi, C. (2013b). "Investigation of the antimicrobial effect of Neosartorya fischeri antifungal protein (NFAP) after heterologous expression in Aspergillus nidulans." Microbiol-SGM 159:411-419.

Galgóczy, L.; Borics, A.; Virágh, M.; Ficze, H.; Váradi, G.; Kele, Z. és Marx, F. (2017). "Structural determinants of Neosartorya fischeri antifungal protein (NFAP) for folding, stability and antifungal activity." Sci Rep. 7:1963.

Garcia-Effron, G.; Chua, D.J.; Tomada, J.R.; DiPersio, J.; Perlin, D.S.; Ghannoum, M. és Bonilla, H. (2010). "Novel FKS mutations associated with echinocandin resistance in Candida species." Antimicrob Agents Chemother 54:2225-2227.

Garrigues, S.; Gandía, M. és Marcos, J.F. (2016). "Occurrence and function of fungal antifungal proteins: a case study of the citrus postharvest pathogen Penicillium digitatum." Appl Microbiol Biotechnol 100:2243-256.

Garrigues, S.; Gandía, M.; Borics, A.; Marx F.; Manzanares, P. és Marcos, J.F. (2017). "Mapping and identification of antifungal peptides in the putative antifungal protein AfpB from the filamentous fungus Penicillium digitatum." Front Microbiol 8:592.

Gasteiger, E.; Hoogland, C.; Gattiker, A.; Duvaud, S.; Wilkins, M.R.; Appel, R.D. és Bairoch A. (2005). "Protein identification and analysis tools on the ExPASy server." In The proteomics protocols handbook, J. M. Walker ed. (New York, Humana Press) 571607.

Geisen, R. (2000). "P, nalgiovense carries a gene which is homologous to the paf gene of $P$, chrysogenum which codes for an antifungal peptide." Int J Food Microbiol 62:516-520.

Gonçalves, S.S.; Souza, A.C.R.; Chowdhary, A.; Meis, J.F. és Colombo, A.L. (2016). "Epidemiology and molecular mechanisms of antifungal resistance in Candida and Aspergillus." Mycoses 59:198-219.

Graessle, S.; Haas, H.; Friedlin, E.; Kürnsteiner, H.; Stöffler, G. és Redl, B. (1997). "Regulated system for heterologous gene expression in Penicillium chrysogenum." Appl Environ Microbiol 63:753-756.

Guinea, J. (2014). "Global trends in the distribution of Candida species causing candidemia." Clin Microbiol Infect 20:5-10.

Gupte, M.; Kulkarni, P. és Ganguli, B.N. (2002). "Antifungal antibiotics." Appl Microbiol Biotechnol 58:46-57. 
Hagen, S.; Marx, F.; Ram, A.F. és Meyer, V. (2007). "The antifungal protein AFP from Aspergillus giganteus inhibits chitin synthesis in sensitive fungi." Appl Environ Microbiol 73:2128-2134.

Hajji, M.; Jellouli, K.; Hmidet, N.; Balti, R.; Sellami-Kamoun, A. és Nasri, M. (2010). "A highly thermostable antimicrobial peptide from Aspergillus clavatus ES1: biochemical and molecular characterization." J Ind Microbiol Biotechnol 37:805-813.

Hall, T.A. (1999). "BioEdit: a user-friendly biological sequence alignment editor and analysis program for Windows 95/98/NT." Nucl Acids Symp Ser 41:95-98.

Hector, R.F. (2005). "An overview of antifungal drugs and their use for treatment of deep and superficial mycoses in animals." Clin Tech Small Anim Pract 20:240-249.

Hegedüs, N.; Sigl, C.; Zadra, I.; Pócsi, I. és Marx, F. (2011). "The paf gene product modulates asexual development in Penicillium chrysogenum." J Basic Microbiol 51:253262.

Hider, R.C.; Kupryszewski, G.; Rekowski, P. és Lammek, B. (1988). "Origin of the positive $225-230 \mathrm{~nm}$ circular dichroism band in proteins. Its application to conformational analysis." Biophys Chem 31:45-51.

Hill, J.A. és Cowen, L.E. (2015). "Using combination therapy to thwart drug resistance." Future Microbiol 10:1719-1726.

Hughes, P.; Dennis, E.; Whitecross, M.; Llewellyn, D. és Gage, P. (2000). "The cytotoxic plant protein, $\beta$-purothionin, forms ion channels in lipid membranes." J Biol Chem 275:823-827.

Hull, C.M.; Parker, J.E.; Bader, O.; Weig, M.; Gross, U.; Warrilow, A.G.S. és mtsi. (2012). "Facultative sterol uptake in an ergosterol-deficient clinical isolate of Candida glabrata harboring a missense mutation in ERG11 and exhibiting cross-resistance to azoles and amphotericin B." Antimicrob Agents Chemother 56:4223-4232.

Johnson, M.D.; MacDougall, C.; Ostrosky-Zeichner, L.; Perfect, J.R. és Rex, J.H. (2004). "Combination antifungal therapy." Antimicrob Agents Chemother 48:693-715.

Jung, D.S.; Farmakiotis, D.; Jiang, Y.; Tarrand, J.J. és Kontoyiannis, D.P. (2015). "Uncommon Candida species fungemia among cancer patients, Houston, Texas, USA." Emerg Infect Dis 21:1942-1950.

Kaiserer, L.; Oberparleiter, C.; Weiler-Görz, R.; Burgstaller, W.; Leiter, E. és Marx, F. (2003). "Characterization of the Penicillium chrysogenum antifungal protein PAF." Arch Microbiol 180:204-210.

Kovács, L.; Virágh, M.; Takó, M.; Papp, T.; Vágvölgyi, C. és Galgóczy, L. (2011). "Isolation and characterization of Neosartorya fischeri antifungal protein (NFAP)." Peptides 32:1724-1731.

Kovács, L. (2014). "A Neosartorya fischeri által termelt defenzinszerü antifungális protein azonosítása és jellemzése." Doktori Értekezés, Mikrobiológiai Tanszék, Természettudományi és Informatikai Kar, Szegedi Tudományegyetem.

Kumar, S.; Stecher, G. és Tamura, K. (2016). "MEGA7: Molecular Evolutionary Genetics Analysis version 7.0 for bigger datasets." Mol Biol Evol 33:1870-1874

Kuse, E.R.; Chetchotisakd, P.; da Cunha, C.A.; Ruhnke, M.; Barrios, C.; Raghunadharao, D. és mtsi. (2007). "Micafungin versus liposomal amphotericin B for candidaemia and invasive candidosis: a phase III randomised double-blind trial." Lancet 369:1519-1527.

Lacadena, J.; del Pozo, A.M.; Gasset, M.; Patiño, B.; Campos-Olivas, R.; Vázquez, C. és mtsi. (1995). "Characterization of the antifungal protein secreted by the mould Aspergillus giganteus." Arch Biochem Biophys 324:273-281.

Lacerda, A.F.; Vasconcelos, E.A.; Pelegrini, P.B. és Grossi de Sa, M.F. (2014). "Antifungal defensins and their role in plant defense." Front Microbiol 5:116. 
Lass-Flörl, C. (2009). "The changing face of epidemiology of invasive fungal disease in Europe." Mycoses 52:197-205.

Lee, G.D.; Shin, S.Y.; Maeng, C.Y.; Jin, Z.Z.; Kim, K.L. és Hahm, K.S. (1999). "Isolation and characterization of a novel antifungal peptide from Aspergillus niger." Biochem Biophys Res Commun 63:646-651.

Lee, D.G.; Park, Y.; Kim, H.N.; Kim, H.K.; Kim, P.I.; Choi, B.H. és Hahm, K.S. (2002). "Antifungal mechanism of an antimicrobial peptide, HP (2-20), derived from N-terminus of Helicobacter pylori ribosomal protein L1 against Candida albicans." Biochem Biophys Res Commun 291:1006-1013.

Lee, J. és Lee, D.G. (2015). "Antimicrobial peptides (AMPs) with dual mechanisms: Membrane disruption and apoptosis." J Microbiol Biotechnol 25:759-764.

Lees, J.G.; Miles, A.J.; Wien, F. és Wallace, B.A. (2006). "A reference database for circular dichroism spectroscopy covering fold and secondary structure space." Bioinformatics 22:1955-1962.

Leiter, E.; Szappanos, H.; Oberparleiter, C.; Kaiserer, L.; Csernoch, L.; Pusztahelyi, T. és mtsi. (2005). "Antifungal protein PAF severely affects the integrity of the plasma membrane of Aspergillus nidulans and induces an apoptosis-like phenotype." Antimicrob Agents Chemother 49:2445-2453.

Leroy, O.; Gangneux, J.P.; Montravers, P.; Mira, J.P.; Gouin, F.; Sollet, J.P. és mtsi. (2009). "Epidemiology, management, and risk factors for death of invasive Candida infections in critical care: a multicenter, prospective, observational study in France (2005-2006)." Crit Care Med 37:1612-1618.

Li, S.; Du, L.; Yuen, G. és Harris, S.D. (2006). "Distinct ceramide synthases regulate polarized growth in the filamentous fungus Aspergillus nidulans." Mol Biol Cell 17:12181227.

Lockhart, S.R.; Iqbal, N.; Cleveland, A.A.; Farley, M.M.; Harrison, L.H.; Bolden, C.B. és mtsi. (2012). "Species identification and antifungal susceptibility testing of Candida bloodstream isolates from population-based surveillance studies in two U.S. cities from 2008 to 2011." J Clin Microbiol 50:3435-3442.

Lockhart, S.R. (2014). "Current Epidemiology of Candida Infection." Clin Microbiol Newsletter 36:131-136.

López-García, B.; Moreno, A.B.; San Segundo, B.; De los Ríos, V.; Manning, J.M.; Gavilanes, J.G. és Martínez del Pozo, A. (2010). "Production of the biotechnologically relevant AFP from Aspergillus giganteus in the yeast Pichia pastoris." Protein Expr Purif 70:206-210.

Loyse, A.; Dromer, F.; Day, J.; Lortholary, O. és Harrison, T.S. (2013). " Flucytosine and cryptococcosis: time to urgently address the worldwide accessibility of a 50-year-old antifungal." J Antimicrob Chemother 68:2435-2444.

Löytynoja, A. és Goldman, N. (2008). "Phylogeny-aware gap placement prevents errors in sequence alignment and evolutionary analysis." Science 320:1632-1635.

Lyon, G.M.; Karatela, S.; Sunay, S.; Adiri, Y. és the Candida Surveillance Study Investigators (2010). "Antifungal susceptibility testing of Candida isolates from the Candida surveillance study." J Clin Microbiol 48:1271-1275.

Martínez-Ruiz, A.; del Pozo, A.M.; Lacadena, J.; Mancheño, J.M.; Oñaderra, M. és Gavilanes, J.G. (1997). "Characterization of a natural larger form of the antifungal protein (AFP) from Aspergillus giganteus." Biochim Biophys Acta 1340:81-87.

Marx, F.; Haas, H.; Reindl, M.; Stöffler, G.; Lottspeich, F. és Redl, B. (1995). "Cloning, structural organization and regulation of expression of the Penicillium chrysogenum paf gene, encoding an abundantly secreted protein with antifungal activity." Gene 167:167171. 
Marx, F. (2004). "Small, basic antifungal proteins secreted from filamentous ascomycetes: a comparative study regarding expression, structure, function and potential application." Appl Microbiol Biotechnol 65:133-142.

Marx, F.; Salvenmoser, W.; Kaiserer, L.; Graessle, S.; Weiler-Görz, R.; Zadra, I. és Oberparleiter, C. (2005). "Proper folding of the antifungal protein PAF is required for optimal activity." Res Microbiol 156:35-46.

Marx, F.; Binder, U.; Leiter, E. és Pócsi, I. (2008). "The Penicillium chrysogenum antifungal protein PAF, a promising tool for the development of new antifungal therapies and fungal cell biology studies." Cell Mol Life Sci 65:445-454.

Masia, C.M. és Gutierrez, R.F. (2002). "Antifungal drug resistance to azoles and polyenes." Lancet Infect Dis 2:550-563.

Maubon, D.; Garnaud, C.; Calandra, T.; Sanglard, D. és Cornet, M. (2014). "Resistance of Candida spp. to antifungal drugs in the ICU: where are we now?" Intensive Care Med 40:1241-1255.

Mazur, P.; Morin, N.; Baginsky, W.; el-Sherbeini, M.; Clemas, J.A.; Nielsen, J.B. és Foor, F. (1995). "Differential expression and function of two homologous subunits of yeast 1,3beta-D-glucan synthase." Mol Cell Biol 15:5671-5681.

McCarty, T.P. és Pappas, P.G. (2016). "Invasive Candidiasis." Infect Dis Clin NA 30:103124.

Meyer, V.; Wedde, M. és Stahl, U. (2002). "Transcriptional regulation of the antifungal protein in Aspergillus giganteus." Mol Genet Genomics 266:747-757.

Meyer, V. és Stahl, U. (2003). "The influence of co-cultivation on expression of the antifungal protein in Aspergillus giganteus." J Basic Microbiol 43:68-74.

Meyer, V. (2008). "A small protein that fights fungi: AFP as a new promising antifungal agent of biotechnological value." Appl Microbiol Biotechnol 78:17-28.

Monk, B.C.; Tomasiak, T.M.; Keniya, M.V.; Huschmann, F.U.; Tyndall, J.D.A.; O’Connell III, J.D. és mtsi. (2014). "Architecture of a single membrane spanning cytochrome P450 suggests constraints that orient the catalytic domain relative to a bilayer." Proc Natl Acad Sci USA 111:3865-3870.

Moreno, A.B.; del Pozo, Á.M.; Borja, M. és San Segudo, B. (2003). "Activity of the antifungal protein from Aspergillus giganteus against Botrytis cinerea." Phytopathology 93:1344-1353.

Moreno, A.B.; del Pozo, Á.M. és San Segudo, B. (2006). "Antifungal mechanism of the Aspergillus giganteus AFP against the rice blast fungus Magnaporthe grisea." Appl Microbiol Biotechnol 54:245-259.

Morgan, J.; Meltzer, M.I.; Plikaytis, B.D.; Sofair, A.N.; Huie-White, S.; Wilcox, S. és mtsi. (2005). "Excess mortality, hospital stay, and cost due to candidemia: a case-control study using data from population-based candidemia surveillance." Infect Control Hosp Epidemiol 26:540-547.

Nawrot, R.; Barylski, J.; Nowicki, G.; Broniarczyk, J.; Buchwald, W. és GoździckaJózefiak, A. (2013). "Plant antimicrobial peptides." Folia Microbiol (Praha) 59:181-196.

Nevalainen, K.M.H.; Téo, V.S.J. és Bergquist, P.L. (2005). "Heterologous protein expression in filamentous fungi." Trends Biotechnol 23:468-474.

Neves-Petersen, M.T.; Gryczynski, Z.; Lakowicz, J.; Fojan, P.; Pedersen, S.; Petersen, E. és Petersen, S.B. (2002). "High probability of disrupting a disulphide bridge mediated by an endogenous excited tryptophan residue." Protein Sci 11:588-600.

Odds, F.C.; Brown, A.J. és Gow, N.A. (2003). "Antifungal agents: mechanisms of action." Trends Microbiol 11:272-279.

Odds, F.C. (2003). "Synergy, antagonism, and what the chequerboard puts between them." J Antimicrob Chemother 52:1. 
Olsen, J.G.; Flensburg, C.; Olsen, O.; Marcus, S.; Bricogne, G. és Henriksen, A. (2004). "Solving the structure of the bubble protein using the anomalous sulfur signal from singlecrystal in-house $\mathrm{Cu}$ Kalpha diffraction data only." Acta Cryst 60:250-255.

Onyewu, C.; Blankenship, J.R.; Del Poeta, M. és Heitman, J. (2003). "Ergosterol biosynthesis inhibitors become fungicidal when combined with calcineurin inhibitors against Candida albicans, Candida glabrata and Candida krusei." Agents Chemother 47:956-964.

Ostrosky-Zeichner, L.; Casadevall, A.; Galgiani, J.N.; Odds, F.C. és Rex, J.H. (2010). "An insight into the antifungal pipeline: selected new molecules and beyond." Nat Rev Drug Discov 9:719-727.

Palczewska, M.; Batta, Gy. és Groves, P. (2003). "Concanavalin A-agarose removes mannan impurities from an extracellularly expressed Pichia pastoris recombinant protein." Cell Mol Biol Lett 8:783-792.

Palicz, Z.; Jenes, A.; Gáll, T.; Miszti-Blasius, K.; Kollár, S.; Kovács, I. és mtsi. (2013). "In vivo application of a small molecular weight antifungal protein of Penicillium chrysogenum (PAF)." Toxicol Appl Pharmacol 269:8-16.

Palicz, Z.; Gáll, T.; Leiter, E.; Kollár, S.; Kovács, I.; Miszti-Blasius, K. és mtsi. (2016). "Application of a low molecular weight antifungal protein from Penicillium chrysogenum (PAF) to treat pulmonary aspergillosis in mice." Emerg Microbes Infect 5:e114.

Papon, N.; Courdavault, V.; Clastre, M. és Bennett, R.J. (2013). "Emerging and emerged pathogenic Candida species: beyond the Candida albicans paradigm." PLoS Pathogens 9:e1003550.

Pappas, P.G.; Rex, J.H.; Lee, J.; Hamill, R.J.; Larsen, R.A.; Powderly, W. és mtsi. (2003). "A prospective observational study of candidemia: epidemiology, therapy, and influences on mortality in hospitalized adult and pediatric patients." Clin Infect Dis 37:634-643.

Pappas, P.G. (2006). "Invasive candidiasis." Infect Dis Clin North Am 20:485-506.

Pappas, P.G.; Kauffman, C.A.; Andes, D.; Benjamin, D.K.; Calandra, T.F.; Edwards, J.E. és mtsi. (2009). " Clinical practice guidelines for the management candidiasis: 2009 update by the Infectious Diseases Society of America." Clin Infect Dis 48:503-535.

Pappas, P.G.; Kauffman, C.A.; Andes, D.R.; Clancy, C.J.; Marr, K.A.; Ostrosky-Zeichner, L. és mtsi. (2016). " Clinical practice guidelines for the management candidiasis: 2016 update by the Infectious Diseases Society of America." Clin Infect Dis 62:e1-e50.

Perfect, J.R.; Dismukes, W.E.; Dromer, F.; Goldman, D.L.; Graybill, J.R.; Hamill, R.J. és mtsi. (2010). "Clinical practice guidelines for the management of cryptococcal disease: 2010 update by the infectious diseases society of America." Clin Infect Dis 50:291-322.

Perlin, D.S. (2007). "Resistance to echinocandin-class antifungal drugs." Drug Resist Updat 10:121-130.

Petersen, T.N.; Brunak, S.; von Heijne, G. és Nielsen, H. (2011). "SignalP 4.0: discriminating signal peptides from transmembrane regions." Nat Methods 8:785-786.

Pevsner, J. (2009). "Basic Local Alignment Search Tool (BLAST)." In: Bioinformatics and Functional Genomics, Second Edition. John Wiley \& Sons Inc., Hoboken, 121-166.

Pfaller, M.A. és Diekema, D.J. (2007). "Epidemiology of invasive candidiasis: a persistent public health problem." Clin Microbiol Rev 20:133-163.

Pfaller, M.A.; Diekema D.J.; Jones, R.N.; Messer, S.A. és Hollis, R.J. (2002). "Trends in antifungal susceptibility of Candida spp. isolated from pediatric and adult patients with bloodstream infections: SENTRY antimicrobial surveillance program, 1997 to 2000." J Clin Microbiol 40:852-856.

Pfaller, M.A.; Diekema D.J.; Gibbs, D.L.; Newell, V.A.; Ellis, D.; Tullio, V.; Rodloff, A.; Fu, W.; Ling, T.A. és a Global Antifungal Surveillance Group (2010). "Results from the ARTEMIS DISK Global Antifungal Surveillance Study, 1997 to 2007: a 10,5-year 
analysis of susceptibilities of Candida species to fluconazole and voriconazole as determined by CLSI standardized disk diffusion." J Clin Microbiol 48:1366-1377.

Pfaller, M.A.; Messer, S.A.; Moet, G.J.; Jones, R.N. és Castanheira, M. (2011). "Candida bloodstream infections: comparison of species distribution and resistance to echinocandin and azole antifungal agents in Intensive Care Unit (ICU) and non-ICU settings in the SENTRY Antimicrobial Surveillance Program (2008-2009)." Int J Antimicrobiol Agents 38:65-69.

Pfaller, M.; Neofytos, D.; Diekema, D.; Azie, N.; Meier-Kriesche, H.; Quan, S. és Horn, D. (2012). "Epidemiology and outcomes of candidemia in 3648 patients: data from the Prospective Antifungal Therapy (PATH Alliance ${ }^{\circledR}$ ) registry, 2004-2008." Diagn Microbiol Infect Dis 74:323-331.

Playford, G.E.; Marriott, D.; Nguyen, Q.; Chen, S.; Ellis, D.; Slavin, M. és Sorrell, T.C. (2008). "Candidemia in nonneutropenic critically ill patients: risk factors for non-albicans Candida spp." Crit Care Med 36: 2034-2039.

Polli, F.; Meijrink, B.; Bovenberg, R.A.L. és Driessen, A.J.M. (2016). "New promoters for strain engineering of Penicillium chrysogenum." Fungal Genet Biol 89:62-71.

Puig-Asensio, M.; Padilla, B.; Garnacho-Montero, J.; Zaragoza, O.; Aguado, J.M.; Zaragoza, R. és mtsi. (2014). "Epidemiology and predictive factors for early and late mortality in Candida bloodstream infections: a population-based surveillance in Spain." Clin Microbiol Infect 20:O245-O254.

Quindós, G. (2014). "Epidemiology of candidaemia and invasive candidiasis. A changing face." Rev Iberoam Micol 31:42-48.

Richardson, M. és Lass-Flörl, C. (2008). "Changing epidemiology of systemic fungal infections." Clin Microbiol Infect 14:5-24.

Rodloff, A.C.; Koch, D. és Schauman, R. (2011). "Epidemiology and antifungal resistance in invasive candidiasis." Eur J Med Res 16: 187-195.

Rodríguez-Martín, A.; Acosta, R.; Liddell, S.; Núñez, F.; Benito, M.J. és Asensio, M.A. (2010). "Characterization of the novel antifungal protein PgAFP and the encoding gene of Penicillium chrysogenum." Peptides 31:541-547.

Roemer, T. és Krysan, D.J. (2014). "Antifungal drug development: challenges, unmet clinical needs, and new approaches." Cold Spring Harb Perspect Med 4:a019703.

Rosano, G.L. és Ceccarelli, E.A. (2014). "Recombinant protein expression in Escherichia coli: advances and challenges." Front Microbiol 5:1-17.

Ruiz-Herrera, J. és Martinez-Espinoza, A.D. (1999). "Chitin biosynthesis and structural organization in vivo." EXS 87:39-53.

Sagaram, U.S.; Pandurangi, R.; Kaur, J.; Smith, T.J. és Shah, D.M. (2011). "Structureactivity determinants in antifungal plant defensins MsDefl and MtDef4 with different modes of action against Fusarium graminearum." PLoS One 6:e18550.

Sanglard, D.; Ischer, F.; Monod, M. és Bille, J. (1997). "Cloning of Candida albicans genes conferring resistance to azole antifungal agents: characterization of CDR2, a new multidrug ABC transporter gene." Microbiology 143:405-416.

Sanglard, D.; Coste, A. és Ferrari, S. (2009). "Antifungal drug resistance mechanisms in fungal pathogens from the perspective of transcriptional gene regulation." FEMS Yeast Res 9:1029-1050.

Seibold, M.; Wolschann, P.; Bodevin, S. és Olsen, O. (2011). "Properties of the bubble protein, a defensin and an abundant component of a fungal exudate." Peptides 32:19891995.

Shapiro, R.S.; Robbins, N. és Cowen, L.E. (2011). "Regulatory circuitry governing fungal development, drug resistance and disease." Microbiol Mol Biol Rev 75:213-267. 
Skouri-Gargouri, H. és Gargouri, A. (2008). "First isolation of a novel thermostable antifungal peptide secreted by Aspergillus clavatus." Peptides 29:1871-1877.

Skouri-Gargouri, H.; Ben, A.M. és Gargouri, A. (2009). "Molecular cloning, structural analysis and modelling of the AcAFP antifungal peptide from Aspergillus clavatus." Peptides 30:1798-1804.

Snelders, E.; Karawajczyk, A.; Verhoeven, R.J.; Venselaar, H.; Schaftenaar, G.; Verweij, P.E. és Melchers, W.J.G. (2011). "The structure-function relationship of the Aspergillus fumigatus cyp51A L98H conversion by site-directed mutagenesis: The mechanism of L98H azole resistance." Fungal Genet Biol 48:1062-1070.

Sonderegger, C.; Galgóczy, L.; Garrigues, S.; Fizil, A.; Borics, A.; Manzanares, P. és mtsi. (2016). "A Penicillium chrysogenum-based expression system for the production of small, cysteine-rich antifungal proteins for structural and functional analyses." Microb Cell Fact 15:192.

Staab, J.F.; Kahn, J.N. és Marr, K.A. (2010). "Differential Aspergillus lentulus echinocandin susceptibilities are Fksp independent." Antimicrob Agents Chemother 54:4992-4998.

Stamatakis, A. (2014). "RAxML version 8: a tool for phylogenetic analysis and postanalysis of large phylogenies." Bioinformatics 30:1312-1313.

Stothard, P. (2000). "The Sequence Manipulation Suite: JavaScript programs for analyzing and formatting protein and DNA sequences." Biotechniques 28:1102-1104.

Su, X.; Schmitz, G.; Zhang, M.; Mackie, R.I. és Cann, I.K.O. (2012). "Heterologous gene expression in filamentous fungi." Adv Appl Microbiol 81:1-61.

Swidergall, M. és Ernst, J.F. (2014). "Interplay between Candida albicans and the antimicrobial peptide armory." Eukaryot Cell 13:950-957.

Szappanos, H.; Szigeti, G.P.; Pál, B.; Rusznák, Z.; Szücs, G.; Rajnavölgyi, E. és mtsi. (2005). "The Penicillium chrysogenum-derived antifungal peptide shows no toxic effects on mammalian cells in the intended therapeutic concentration." Naunyn Schmiedebergs Arch Pharmacol 371:122-132.

Szappanos, H.; Szigeti, G.P.; Pál, B.; Rusznák, Z.; Szűcs, G.; Rajnavölgyi, E. és mtsi. (2006). "The antifungal protein AFP secreted by Aspergillus giganteus does not cause detrimental effects on certain mammalian cells." Peptides 27:1717-1725.

Talavera, G. és Castresana, J. (2007). "Improvement of phylogenies after removing divergent and ambiguously aligned blocks from protein sequence alignments." Syst Biol 56:564-577.

Talbot, N.J. (2003). "On the trail of a cereal killer: exploring the biology of Magnaporthe grisea." Annu Rev Microbiol 57:177-202.

Tam. J.P.; Wang, S.; Wong, K.H. és Tan, W.L. (2015). "Antimicrobial peptides from plants." Pharmaceuticals (Basel) 8:711-757.

Theis, T.; Wedde, M.; Meyer, V. és Stahl, U. (2003). "The antifungal protein from Aspergillus giganteus causes membrane permeabilization." Antimicrob Agents Chemother 47:588-593.

Theis, T.; Marx, F.; Salvenmoser, W.; Stahl, U. és Meyer, V. (2005). "New insights into the target site and mode of action of the antifungal protein of Aspergillus giganteus." Res Microbiol 156:47-56.

Tortorano, A.M.; Kibbler, C.; Peman, J.; Bernhardt, H.; Klingspor, L. és Grillot, R. (2006). "Candidemia in Europe: epidemiology and resistance." Int J Antimicrob Agents 27:359366.

Tu, C.Y.; Chen, Y.P.; Yu, M.C.; Hwang, I.E.; Wu, D.Y. és Liaw, L.L. (2016). "Characterization and expression of the antifungal protein from Monascus pilosus and its distribution among various Monascus species." J Biosci Bioeng 122:27-33. 
Váradi, G.; Tóth, G.K.; Kele, Z.; Galgóczy, L.; Fizil, A. és Batta, G. (2013). "Synthesis of $\mathrm{PAF}$, an antifungal protein from $P$, chrysogenum, by native chemical ligation: native disulfide pattern and fold obtained upon oxidative refolding." Chem-Eur J 19:1268412692.

Vila, L.; Lacadena, V.; Fontanet, P.; Martínez del Pozo, A. és San Segundo, B. (2001). "A protein from the mold Aspergillus giganteus is a potent inhibitor of fungal plant pathogens." Mol Plant Microbe Interact 14:1327-1331.

Virágh, M.; Vörös, D.; Kele, Z.; Kovács, L.; Fizil, A.; Lakatos, G. és mtsi. (2014). "Production of a defensin-like antifungal protein NFAP from Neosartorya fischeri in Pichia pastoris and its antifungal activity against filamentous fungal isolates from human infections." Protein Expr Purif 94:79-84.

Virágh, M.; Marton, A.; Vizler, C.; Tóth, L.; Vágvölgyi, C.; Marx, F. és Galgóczy, L. (2015). "Insight into the antifungal mechanism of Neosartorya fischeri antifungal protein." Protein Cell 6:518-528.

Virágh, M. (2015). "A Neosartorya fischeri antifungális protein (NFAP) heterológ expressziója és hatásmechanizmusának vizsgálata." Doktori Értekezés, Mikrobiológiai Tanszék, Természettudományi és Informatikai Kar, Szegedi Tudományegyetem.

Vuister, G.W. és Bax, A. J. (1992). "Resolution enhancement and spectral editing of uniformly ${ }^{13} \mathrm{C}$-enriched proteins by homonuclear broadband ${ }^{13} \mathrm{C}$ decoupling." $\mathrm{J}$ Magn Reson 98:428-435.

Walker, L.A.; Munro, C.A.; de Bruijn, I.; Lenardon, M.D.; McKinnon, A. és Gow, N.A. (2008). "Stimulation of chitin synthesis rescues Candida albicans from echinocandins." PLoS Pathog 4:e1000040.

Walker, L.A.; Gow, N.A. és Munro, C.A. (2010). "Fungal echinocandin resistance." Fungal Genet Biol 47:117-126.

Walker, L.A.; Gow, N.A. és Munro, C.A. (2013). "Elevated chitin content reduces the susceptibility of Candida species to caspofungin." Antimicrob Agents Chemother 57:146-154.

Walsh, T.J.; Anaissie, E.J.; Denning, D.W.; Herbrecht, R.; Kontoyiannis, D.P.; Marr, K.A. és mtsi. (2008). "Treatment of aspergillosis: clinical practice guidelines of the Infectious Diseases Society of America." Clin Infect Dis 46:327-360.

Wang, Y.H.; Zhang, J.P.; Chang, Y. és Hu, C.Q. (2010). "A newly identified derivative of amphotericin B: isolation, structure determination and primary evaluation of the activity and toxicity." J Antibiot (Tokyo) 63:553-557.

Wheat, L.J.; Freifeld, A.G., Kleiman, M.B.; Baddley, J.W.; McKinsey, D.S.; Loyd, J.E. és Kauffman, C.A. (2007). "Clinical practice guidelines for the management of patients with histoplasmosis: 2007 update by the infectious diseases society of America." Clin Infect Dis 45:807-825.

Wnendt, S.; Ulbrich, N. és Stahl, U. (1990). "Cloning and nucleotide sequence of a cDNA encoding the antifungal-protein of Aspergillus giganteus and preliminary characterization of the native gene." Nucleic Acids Res 18:3987.

Wnendt, S.; Ulbrich, N. és Stahl, U. (1994). "Molecular cloning, sequence analysis and expression of the gene encoding an antifungal-protein from Aspergillus giganteus." Curr Genet 25:519-523.

Zimmermann, G.R.; Lehar, J. és Keith, C.T. (2007). "Multi-target therapeutics: when the whole is greater than the sum of the parts." Drug Discovery Today 12:34-42.

Yapar, N. (2014). "Epidemiology and risk factors for invasive candidiasis." Ther Clin Risk Manag 10:95-105.

Yount, N.Y. és Yeaman, M.R. (2004). "Multidimensional signatures in antimicrobial peptides." Proc Natl Acad Sci USA 101:7363-7368. 


\section{KÖSZÖNETNYILVÁNÍTÁS}

Mindenekelőtt köszönetemet szeretném kifejezni Prof. Dr. Vágvölgyi Csabának, aki lehetővé tette, támogatta és segítette szakdolgozói és doktori munkámat a Szegedi Tudományegyetem, TTIK, Mikrobiológiai Tanszékén. Köszönetemet fejezem ki témavezetői munkájáért, hasznos szakmai tanácsaiért, támogatásáért.

Köszönettel tartozom témavezetőmnek, Dr. Galgóczi Lászlónak, aki az elmúlt évek során irányította, figyelemmel kísérte és segítette munkámat. Áldozatos munkája, szakmai tanácsai és bátorítása nagyban hozzájárultak a dolgozat elkészüléséhez.

Külön köszönet illeti Dr. Papp Tamást a doktori dolgozat kutatási témájának támogatásáért.

Szeretném megköszönni Dr. Virágh Máténak, hogy témavezetőm távollétében hasznos szakmai és baráti tanácsaival segítette munkámat.

Köszönetemet fejezem ki Dr. Váradi Györgyinek a kémiai peptid- és proteinszintézisben, illetve a fehérjetisztításban nyújtott segítségéért, Dr. Kele Zoltánnak a tömegspektrometriás mérésekben és fehérjeazonosításban nyújtott segítségéért és Prof. Dr. Tóth K. Gábornak a fenti munkák támogatásáért (SZTE, ÁOK, Orvosi Vegytani Intézet).

Köszönettel tartozom Prof. Dr. Batta Gyulának, Dr. Czajlik Andrásnak (DE, TTK, Szerves Kémiai Tanszék) és Dr. Borics Attilának (MTA, SZBK, Biokémiai Intézet) a fehérjeszerkezet-vizsgálatban nyújtott segítségükért.

Hálával tartozom Dr. Kocsubé Sándornak és Dr. Nagy G. Lászlónak a filogenetikai analízis során nyújtott segítségükért és Dr. Takó Miklósnak a fehérjetisztításban nyújtott segítségéért.

Köszönöm a 312. labor valamennyi munkatársának szakmai segítségüket és barátságukat. Külön szeretném megköszönni Dr. Baranyi Nikolettnek, Dr. Homa Mónikának és Vidács Anitának, hogy az elmúlt évek során mindig türelemmel és barátsággal fordultak hozzám, bátorítottak, és ezzel nagyban hozzájárultak a dolgozatom elkészüléséhez.

Köszönettel tartozom volt és jelenlegi szakdolgozóinknak, Ficze Hargitának és Tóth Robertának, akik munkájukkal szintén hozzájárultak a dolgozat kutatási eredményeihez.

Emellett köszönetemet fejezem ki a tanszék valamennyi volt és jelenlegi munkatársának és mindazoknak, akik bármilyen módon segítették a dolgozat elkészültét.

Szeretném megköszönni barátaimnak, elsősorban Gódor Nikolettának, Kisvárdai Mírának, Ámon Juditnak és Csonka Katának bíztató szavaikat és lelki támogatásukat. 
Végül, de nem utolsósorban külön köszönet illeti családomat és páromat, akik szeretetükkel és támogatásukkal segítették tanulmányaimat és dolgozatom elkészültét.

A disszertáció az "Opportunista és felbukkanó gombafertőzések patomechanizmusa" (GINOP-2.3.2-15-2016-00035) címü projekt támogatásával készült (Széchenyi 2020 Program) 2017-ben. 


\section{MELLÉKLETEK}

1. számú melléklet. A pSK275nfap2 expressziós vektor létrehozásának lépései. Az érett NFAP2-t kódoló cDNS-t sárga kiemeléssel jelöltük, a paf preproszekvenciát piros, dőlt betűk, az 5'- és 3'-UTR-t lila és kék betűk mutatják. A restrikciós endonukleázok hasítóhelyeit aláhúzással és függőleges nyilakkal jelöltük.

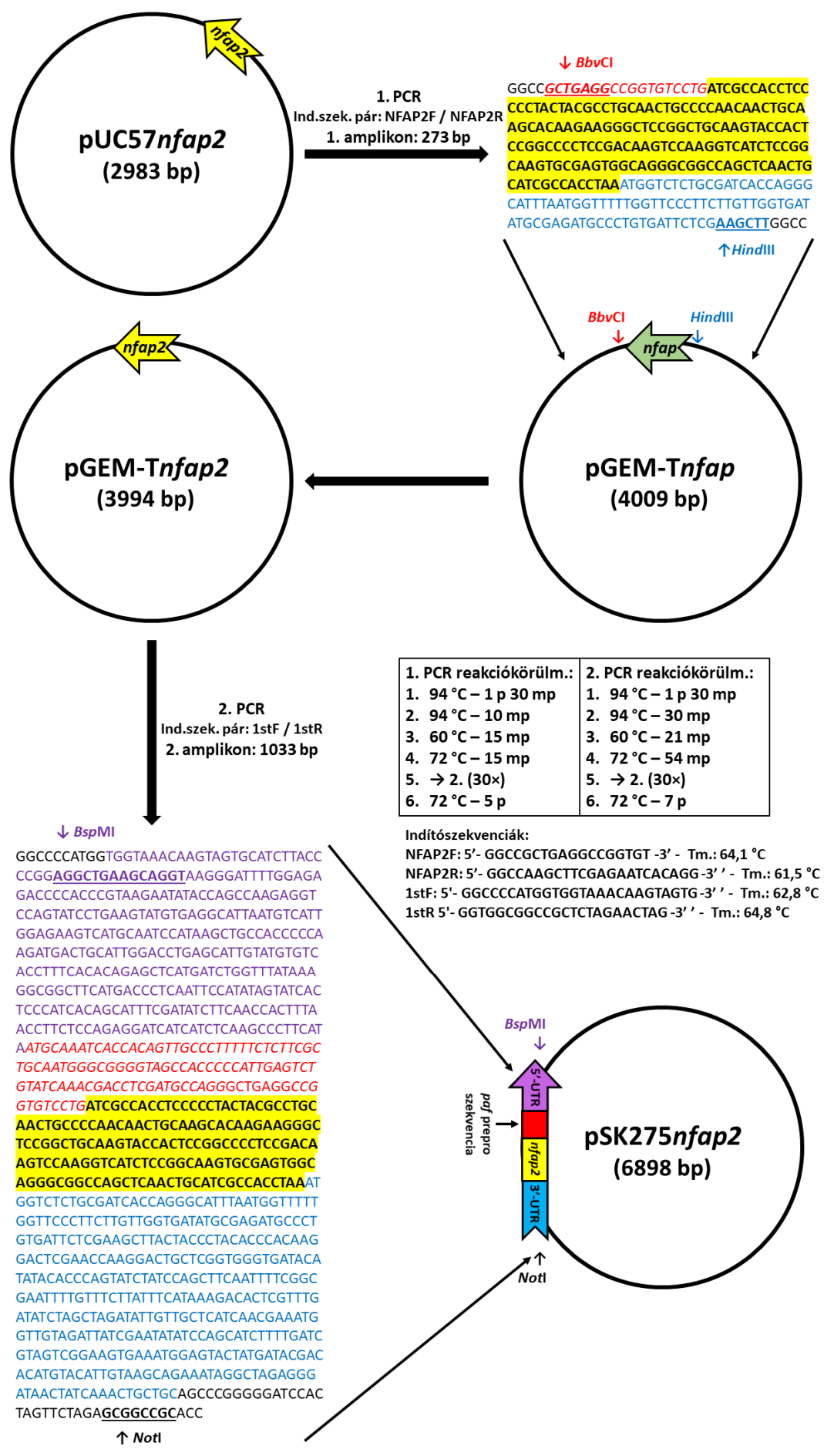


2. számú melléklet. Fonalas tömlősgomba-eredetü feltételezett NFAP2 homológ proteinek aminosav-szekvenciáinak illesztése. A piros vonal a lehetséges szignálszekvencia hasítóhelyét jelöli (SignalP1 4.1 server; Petersen és mtsi., 2011). Az azonosítószám vagy a protein azonosítószáma az ábrán látható, a hozzá tartozó termelő izolátum pedig a 3. számú mellékletben került feltüntetésre.

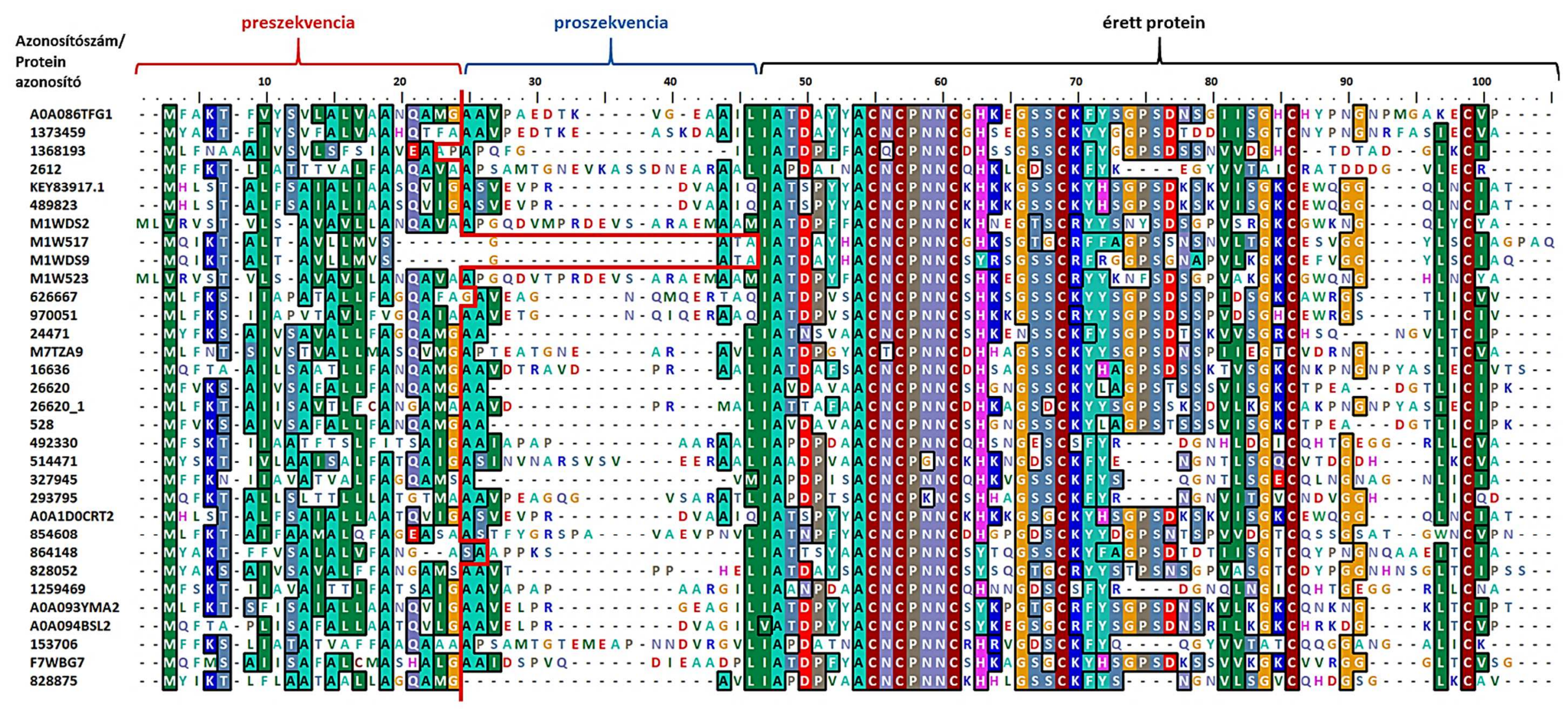


3. számú melléklet. A fonalas tömlősgombák genomjában azonosított NFAP2-, PAF- illetve BP-klaszter és homológ proteinek.

\begin{tabular}{|c|c|c|c|c|c|}
\hline Gomba & Protein neve & $\begin{array}{c}\text { Azonosítószám } \\
\text { /Protein } \\
\text { azonosító }\end{array}$ & Aminosav-szekvencia & Egyéb információk & Adatbázis \\
\hline \multicolumn{6}{|c|}{ NFAP2-klaszter } \\
\hline $\begin{array}{l}\text { Acremonium chrysogenum } \\
\text { ATCC } 11550\end{array}$ & nem jellemzett protein ACRE_009950 & A0A086TFG1 & $\begin{array}{l}\text { MFAKTFVYSVLALVAANQAMGAAVPAEDTKVGEAAILIATDAYYACNCPNN } \\
\text { CGHKEGSSCKFYSGPSDNSGIISGHCHYPNGNPMGAKECVP }\end{array}$ & n.a. & UniProtKB \\
\hline \multirow{2}{*}{$\begin{array}{l}\text { Acremonium strictum } \\
\text { DS1bioAY4a }\end{array}$} & gm1.11729_g & 1373459 & $\begin{array}{l}\text { MYAKTFIYSVFALVAAHQTFAAAVPEDTKEASKDAAILIATDAYYACNCPNN } \\
\text { CGHSEGSSCKYYGGPSDTDDIISGTCNYPNGNRFASIECVA }\end{array}$ & \multirow{2}{*}{ n.a. } & \multirow{2}{*}{ JGI } \\
\hline & gm1.6463_g & 1368193 & $\begin{array}{l}\text { MLFNAAAIVSVLSFSIAVEAAPAPQFGILIATDPFFACQCPNNCDHSSGSSCKF } \\
\text { YGGPSDSSNVVDGHCTDTADGLKCI }\end{array}$ & & \\
\hline Alternaria brassicicola & AB02612.1 & 2612 & $\begin{array}{l}\text { MFFKTLLATTTVALFAAQAVAAPSAMTGNEVKASSDNEARAALIAPDAINAC } \\
\text { NCPNNCQHKLGDSCKFYKEGYVVTAICRATDDDGVLECR }\end{array}$ & n.a. & JGI \\
\hline $\begin{array}{l}\text { Aspergillus fumigatus } \\
\quad \text { var. RP-2014 }\end{array}$ & nem jellemzett protein BA78_8705 & KEY83917.1 & $\begin{array}{l}\text { MHLSTALFSAIALIAASQVIGASVEVPRDVAAIQIATSPYYACNCPNNCKHKK } \\
\text { GSSCKYHSGPSDKSKVISGKCEWQGGQLNCIAT }\end{array}$ & $\begin{array}{l}\text { Eredet: Brazília } \\
\text { Izoláció: trópusi erdei talaj } \\
(2007)\end{array}$ & NCBI \\
\hline $\begin{array}{l}\text { Byssothecium circinans } \\
\text { CBS } 675.92\end{array}$ & $\begin{array}{c}\text { fgenesh1_kg.8_\#_209_\#_Locus10000v1rpk } \\
\text { m3.04 }\end{array}$ & 489823 & $\begin{array}{l}\text { MHLSTALFSAIALIAASQVIGASVEVPRDVAAIQIATSPYYACNCPNNCKHKK } \\
\text { GSSCKYHSGPSDKSKVISGKCEWQGGQLNCIAT }\end{array}$ & $\begin{array}{l}\text { Eredet: USA, Dél-Dakota } \\
\text { Izoláció: rothadó fakorona } \\
\text { Szubsztrát: Medicago sativa }\end{array}$ & JGI \\
\hline \multirow{4}{*}{ Claviceps purpurea 20.1} & nem jellemzett protein CPUR_03466 & M1WDS2 & $\begin{array}{l}\text { MLVRVSTVLSAVAVLLANQAVAAPGQDVMPRDEVSARAEMAAMIATDPFF } \\
\text { ACNCPNNCKHNEGTSCRYYSNYSDSGPVSRGKCGWKNGQLYCYA }\end{array}$ & \multirow{4}{*}{ n.a. } & \multirow{4}{*}{ UniProtKB } \\
\hline & nem jellemzett protein CPUR_03467 & M1W517 & $\begin{array}{l}\text { MQIKTALTAVLLMVSGATAIATDAYHACNCPNNCGHKSGTGCRFFAGPSSNS } \\
\text { NVLTGKCESVGGYLSCIAGPAQ }\end{array}$ & & \\
\hline & nem jellemzett protein CPUR_03481 & M1WDS9 & $\begin{array}{l}\text { MQIKTALTAVLLMVSGATAIATDAYHACNCPNNCSYRSGSSCRFRGGPSGNA } \\
\text { PVLKGKCEFVGGYLSCIAQ }\end{array}$ & & \\
\hline & nem jellemzett protein CPUR_03482 & M1W523 & $\begin{array}{l}\text { MLVRVSTVLSAVAVLLANQAVAAPGQDVTPRDEVSARAEMAAMIATDPYFA } \\
\text { CNCPNNCSHKEGSSCRYYKNFSDSGPVAKGKCGWQNGHLNCYA }\end{array}$ & & \\
\hline
\end{tabular}




\begin{tabular}{|c|c|c|c|c|c|}
\hline $\begin{array}{l}\text { Coniochaeta ligniaria } \\
\quad \text { NRRL } 30616\end{array}$ & $\begin{array}{c}\text { fgenesh1_kg.1_\#_380_\#_Locus1 1190v1rpk } \\
\mathrm{m} 0.72\end{array}$ & 626667 & $\begin{array}{l}\text { MLFKSIIAPATALLFAGQAFAGAVEAGNQMQERTAQIATDPVSACNCPNNCS } \\
\text { HKSGSSCKYYSGPSDSSPIDSGKCAWRGSTLICVV }\end{array}$ & n.a. & JGI \\
\hline Coniochaeta sp. PMI_546 & gm1.7183_g & 970051 & $\begin{array}{l}\text { MLFKSIIAPVTAVLFVGQAIAAAVETGNQIQERAAQIATDPVSACNCPNNCSH } \\
\text { KKGSSCRYYSGPSDSSPVDSGHCEWRGSTLICIV }\end{array}$ & Izoláció: Populus deltoides & JGI \\
\hline Daldinia eschscholzii $\mathrm{EC} 12$ & gm1.7079_g & 24471 & $\begin{array}{l}\text { MYFKSAIVSAVALLFAGQAMGAALIATNSVAACNCPNNCSHKENSSCKFYSG } \\
\text { PSDTSKVVSGRCHSQNGVLTCIP }\end{array}$ & n.a. & JGI \\
\hline Eutypa lata UCR-EL1 & hipotetikus protein UCREL1_925 & M7TZA9 & $\begin{array}{l}\text { MLFNTSIVSTVALLMASQVMGAPTEATGNEARAVLIATDPGYACTCPNNCDH } \\
\text { HAGSSCKYYSGPSDNSPIIEGTCVDRNGLTCVA }\end{array}$ & n.a. & UniProtKB \\
\hline Hypoxylon sp. CI-4A & gm1.10063_g & 16636 & $\begin{array}{l}\text { MQFTAAILSAATLLFANQAMGAAVDTRAVDPRAALIATDAFSACNCPNNCD } \\
\text { HSAGSSCKYHAGPSDSSKTVSGKCNKPNGNPYASLECIVTS }\end{array}$ & n.a. & JGI \\
\hline Hypoxylon sp. CO27-5 & gm1.426_g & 26620 & $\begin{array}{l}\text { MFVKSAIVSAFALLFANQAMGAALIAVDAVAACNCPNNCSHGNGSSCKYLA } \\
\text { GPSTSSSVISGKCTPEADGTLICIPK }\end{array}$ & n.a. & JGI \\
\hline Hypoxylon sp. CO27-5 & gm1.7264_g & 26620_1 (33458) & $\begin{array}{l}\text { MLFKTAIISAVTLFCANGAMAAAVDPRMALIATTAFAACNCPNNCDHKAGSD } \\
\text { CKYYSGPSSKSDVLKGKCAKPNGNPYASIECIP }\end{array}$ & n.a. & JGI \\
\hline Hypoxylon sp. EC38 & $\mathrm{gm} 1.528 \_\mathrm{g}$ & 528 & $\begin{array}{l}\text { MFVKSAIVSAFALLFANQAMGAALIAVDAVAACNCPNNCSHGNGSSCKYLA } \\
\text { GPSTSSSVISGKCTPEADGTLICIPK }\end{array}$ & n.a. & JGI \\
\hline $\begin{array}{l}\text { Karstenula rhodostoma } \\
\text { CBS } 690.94\end{array}$ & gm1.14118_g & 492330 & $\begin{array}{l}\text { MFSKTIIAATFTSLFITSAIGAAIAPAPAARAALIAPDPDAACNCPNNCQHSNGE } \\
\text { SCSFYRDGNHLDGICQHTGEGGRLLCVA }\end{array}$ & $\begin{array}{l}\text { Eredet: Svédország } \\
\text { Szubsztrát: Frangula alnus } \\
\text { Izolálás: 25/02/1986 }\end{array}$ & JGI \\
\hline $\begin{array}{l}\text { Massarina eburnea } \\
\text { CBS } 473.64\end{array}$ & gm1.2277_g & 514471 & $\begin{array}{l}\text { MYSKTIVLAAISALFATQAIGASINVNARSVSVEERAALIAADPVAACNCPGN } \\
\text { CKHKNGDSCKFYENGNTLSGQCVTDGDHLKCVA }\end{array}$ & $\begin{array}{l}\text { Eredet: Svájc, Zürich, } \\
\text { Talstrasse, Rehalp erdő } \\
\text { Szubsztrát: Fagus sylvatica }\end{array}$ & JGI \\
\hline Melanomma pulvis-pyrius & $\begin{array}{c}\text { fgenesh1_kg.370_\#_2_\#_Locus74v1 rpkm13 } \\
68.98\end{array}$ & 327945 & $\begin{array}{l}\text { MFFKNIIAVATVALFAGQAMSAVMIAPDPISACNCPNNCQHKVGSSCKFYSQ } \\
\text { GNTLSGECQLNGNAGNLICIA }\end{array}$ & n.a. & JGI \\
\hline $\begin{array}{l}\text { Myriangium duriaei } \\
\text { CBS } 260.36\end{array}$ & gm1.4858_g & 293795 & $\begin{array}{l}\text { MQFKTALLSLTTLLLATGTMAAAVPEAGQGVSARATLIAPDPTSACNCPKNC } \\
\text { SHHAGSSCKFYRNGNVITGVCNDVGGHLICQD }\end{array}$ & $\begin{array}{l}\text { Eredet: Argentína, Delta del } \\
\text { Paraná } \\
\text { Szubsztrát: Chrysomphalus }\end{array}$ & JGI \\
\hline $\begin{array}{l}\text { Neosartorya fischeri } \\
\quad \text { NRRL } 181\end{array}$ & NFAP2 & A0A1D0CRT2 & $\begin{array}{l}\text { MHLSTALFSAIALLAATQVIGASVEVPRDVAAIQIATSPYYACNCPNNCKHKK } \\
\text { GSGCKYHSGPSDKSKVISGKCEWQGGQLNCIAT }\end{array}$ & n.a. & UniProtKB \\
\hline
\end{tabular}




\begin{tabular}{|c|c|c|c|c|c|}
\hline \multirow{3}{*}{ Niesslia exilis CBS 358.70} & estExt_Genemark1.C_1_t10048 & 854608 & $\begin{array}{l}\text { MLFKTAIFAAMALQFAGEASAASTFYGRSPAVAEVPNVLIATNPFYACNCPN } \\
\text { NCDHGPGDSCKYYDGPSNTSPVVDGTCQSSGSATGWNCVPN }\end{array}$ & \multirow{3}{*}{$\begin{array}{l}\text { Eredet: Hollandia, Noord } \\
\text { Brabant, Kampina Heide. } \\
\text { Szubsztrát: Pteridium } \\
\text { aquilinum }\end{array}$} & \multirow{3}{*}{ JGI } \\
\hline & estExt_Genemark1.C_190067 & 864148 & $\begin{array}{l}\text { MYAKTFFVSALALVFANGASAAPPKSLIATTSYAACNCPNNCSYTQGSSCKY } \\
\text { FAGPSDTDTIISGTCQYPNGNQAAEITCIA }\end{array}$ & & \\
\hline & gm1.8228_g & 828052 & $\begin{array}{l}\text { MYAKSAIVSAVALFFANGAMSAAVTPPHELIATDAYSACNCPNNCSYSQGTG } \\
\text { CRYYSTPSNSGPVASGTCDYPGGNHNSGLTCIPSS }\end{array}$ & & \\
\hline $\begin{array}{l}\text { Paraconiothyrium sporulosum } \\
\text { AP3s5-JAC2a }\end{array}$ & estExt_Genemark1.C_5_t20273 & 1259469 & $\begin{array}{l}\text { MFSKTIIAVAITTLFATSAIGAAVAPAPAARGILIAANPDAACNCPNNCQHNNG } \\
\text { DSCSFYRDGNQLNGICQHTGEGGRLLCNA }\end{array}$ & n.a. & JGI \\
\hline $\begin{array}{l}\text { Pseudogymnoascus pannorum } \\
\text { VKM F-3808 }\end{array}$ & hipotetikus protein O988_03546 & A0A093YMA2 & $\begin{array}{l}\text { MLFKTSFISAIALLAANQVIGAAVELPRGEAGILIATDPYYACNCPNNCSYKPG } \\
\text { TGCRFYSGPSDNSKVLKGKCQNKNGKLTCIPT }\end{array}$ & $\begin{array}{l}\text { Eredet: Oroszország, } \\
\text { Tverskaya oblast. } \\
\text { Izoláció: haj }\end{array}$ & UniProtKB \\
\hline $\begin{array}{l}\text { Pseudogymnoascus pannorum } \\
\text { VKM F-4513 }\end{array}$ & hipotetikus protein V494_01379 & A0A094BSL2 & $\begin{array}{l}\text { MQFTAPLISAFALLAATQVLGAAVELPRDVAGILVATDPYYACNCPNNCSYK } \\
\text { EGSGCRFYSGPSDNSRILKGKCHRKDGKLTCVP }\end{array}$ & $\begin{array}{l}\text { Eredet: Oroszország, Kolyma } \\
\text { Lowland. } \\
\text { Izoláció: permafrost talaj }\end{array}$ & UniProtKB \\
\hline Pyrenophora tritici-repentis & PTRT_08027 & 153706 & $\begin{array}{l}\text { MFFKSLIATATVAFFAAQAAAAPSAMTGTEMEAPNNDVRGVLIAPDATNACN } \\
\text { CPNNCRHRVGDSCKFYQQGYVVTATCQQGGANGALICK }\end{array}$ & n.a. & JGI \\
\hline Sordaria macrospora K-hell & hipotetikus protein SMAC_09189 & F7WBG7 & $\begin{array}{l}\text { MQFMSAIISAFALCMASHALGAAIDSPVQDIEAADPLIATDPFYACNCPNNCS } \\
\text { HKAGSGCKYHSGPSDKSSVVKGKCVVRGGGLTCVSG }\end{array}$ & Szövet típus: mycelium & UniProtKB \\
\hline Thozetella sp. PMI_491 & gm1.14407_g & 828875 & $\begin{array}{l}\text { MYIKTLFLAATAALLAGQAMGAVLIAPDPVAACNCPNNCKHHLGSSCKFYSN } \\
\text { GNVLSGVCQHDGSGLKCAV }\end{array}$ & $\begin{array}{l}\text { Eredet: Ausztrália } \\
\text { Izoláció: fakéreg }\end{array}$ & JGI \\
\hline \multicolumn{6}{|c|}{ PAF-klaszter } \\
\hline $\begin{array}{l}\text { Apiospora montagnei } \\
\text { NRRL } 25634\end{array}$ & MIX11387_2_52 & 719503 & $\begin{array}{l}\text { MQFSTVALFLFAVVGAVANPVEGSADGIDARELQITYDGTCSRSKNECKYKG } \\
\text { QNGRTTIVKCPSFANKKCTRDGAKCSFDSHSRKVTCH }\end{array}$ & n.a. & JGI \\
\hline Aspergillus brasiliensis & $\begin{array}{c}\text { fgenesh1_kg.5_\#_8_\#_Locus37v1 rpkm4132. } \\
66\end{array}$ & 41941 & $\begin{array}{l}\text { MGAIANPIAAEADDLLAREAQLSKYGGECSLEHNTCTYRKDGKNHVVACPT } \\
\text { AANLRCKTDRHHCEYDDHHKTVDCQTPV }\end{array}$ & n.a. & JGI \\
\hline
\end{tabular}




\begin{tabular}{|c|c|c|c|c|c|}
\hline $\begin{array}{l}\text { Aspergillus campestris } \\
\text { IBT } 28561\end{array}$ & estExt_Genemark1.C_10_t10236 & 329071 & $\begin{array}{l}\text { MQLISLASMGLVLFAAVGAVASPVDNNALDVNDNLEVHDEAATLITYNGSCS } \\
\text { KKNNSCKYKGQKGKTSFCHCKFKKCGKDGNKCHFDSYSRDCKCI }\end{array}$ & n.a. & JGI \\
\hline Aspergillus clavatus $\mathrm{ES} 1$ & anitmikrobiális peptid & D3Y2M3 & $\begin{array}{l}\text { MKVVSLASLGFALVAALGVAASPVDADSLAAGGLDARDESAVQATYDGKC } \\
\text { YKKDNICKYKAQSGKTAICKCYVKVCPRDGAKCEFDSYKGKCYC }\end{array}$ & $\begin{array}{l}\text { Eredet: Tunézia, Sfax } \\
\text { Izoláció: szennyvíz }\end{array}$ & UniProtKB \\
\hline $\begin{array}{c}\text { Aspergillus clavatus } \\
\text { NRRL } 1 \\
\text { (ATCC } 1007 \text { / CBS } 513.65 \text { / } \\
\text { DSM } 816 \text { / NCTC 3887) }\end{array}$ & antifungális protein Afp & A1CSS4 & $\begin{array}{l}\text { MKVVSLASLGFALVAALGVVASPVDADSLAAGGLDARDESAVQATYDGKC } \\
\text { YKKDNICKYKAQSGKTAICKCYVKVCPRDGAKCEFDSYKGKCYC }\end{array}$ & n.a. & UniProtKB \\
\hline $\begin{array}{l}\text { Aspergillus clavatus VR1 } \\
\quad \text { (CTM 10.520) }\end{array}$ & antifungális protein & A6N2V2 & $\begin{array}{l}\text { MKFVSLASLGFALVAALGVVASPVDADSLAAGGLDARDESAVQATYDGKCY } \\
\text { KKDNICKYKAQSGKTAICKCYVKVCPRDGAKCEFDSYKGKCYC }\end{array}$ & $\begin{array}{l}\text { Eredet: Tunézia, Sfax } \\
\text { Izoláció: szennyezett táptalaj }\end{array}$ & UniProtKB \\
\hline $\begin{array}{l}\text { Aspergillus giganteus } \\
\text { MDH } 18894\end{array}$ & antifungális protein & P17737 & $\begin{array}{l}\text { MKFVSLASLGFALVAALGAVATPVEADSLTAGGLDARDESAVLATYNGKCY } \\
\text { KKDNICKYKAQSGKTAICKCYVKKCPRDGAKCEFDSYKGKCYC }\end{array}$ & $\begin{array}{l}\text { Eredet: USA, Michigan } \\
\text { Izoláció: talaj }\end{array}$ & UniProtKB \\
\hline $\begin{array}{l}\text { Aspergillus kawachii IFO } 4308 \\
\quad \text { (NBRC 4308) }\end{array}$ & nem jellemzett protein & G7XGG7 & $\begin{array}{l}\text { MQLTNIAIILFAAMGAIANPIAAESDDLLARDAQLSKYGGECSLEHNTCTYRK } \\
\text { DGKNHVVSCPSATNKRCKTDRHHCEYDDHHKTVDCQTPV }\end{array}$ & Eredet: Japán & UniProtKB \\
\hline $\begin{array}{l}\text { Aspergillus luchuensis } \\
\qquad \text { CBS } 106.47\end{array}$ & estExt_Genemark1.C_2_t10089 & 214633 & $\begin{array}{l}\text { MQLTSIAIILFAAMGAIANPIAAESDDLLARDAQLSKYGGECSLEHNTCTYRK } \\
\text { DGKNHVVSCPSATNLRCKTDRHHCEYDDHHKTVDCQTPV }\end{array}$ & Eredet: Svájc, Basel & JGI \\
\hline $\begin{array}{l}\text { Aspergillus niger ATCC } 1015 \\
\text { (ATCC 10582, CBS 113.46, IMI } \\
\text { 31821, LSHB Ac4, NCTC } \\
\text { 3858a, NRRL 1278, NRRL 328, } \\
\text { NRRL 350, NRRL 511, TC 167) }\end{array}$ & estExt_Genemark1.C_chr_401_t10108 & 1183897 & $\begin{array}{l}\text { MQLTSIAIILFAAMGAIATPITAEADNLAAREAELSKYGGECSVEHNTCTYLK } \\
\text { GGKDHIVSCPSAANLRCKTERHHCEYDEHHKTVDCQTPV }\end{array}$ & n.a. & JGI \\
\hline $\begin{array}{l}\text { Aspergillus niger CBS } 513.88 \\
\qquad \text { (FGSC A1513) }\end{array}$ & $\begin{array}{l}\text { An } 07 \mathrm{~g} 01320 \mathrm{~m} .01 \\
\text { Aspergillus niger contig An } 07 \mathrm{c} 0020, \\
\text { genomic contig }\end{array}$ & A2QM98 & $\begin{array}{l}\text { MQLTSIAIILFAAMGAIANPIAAEADNLVAREAELSKYGGECSVEHNTCTYLK } \\
\text { GGKDHIVSCPSAANLRCKTERHHCEYDEHHKTVDCQTPV }\end{array}$ & n.a. & UniProtKB \\
\hline Aspergillus niger КСТС 2025 & antifungális protein & A2QM98 & $\begin{array}{l}\text { LSKYGGECSLEHNTCTYRKDGKNHVVSCPSAANLRCKTDRHHCEYDDHHKT } \\
\text { VDCQTPV } \\
\text { Full: n.a. }\end{array}$ & n.a. & UniProtKB \\
\hline
\end{tabular}




\begin{tabular}{|c|c|c|c|c|c|}
\hline $\begin{array}{l}\text { Aspergillus phoenicis (Corda) } \\
\text { Thom ATCC } 13157\end{array}$ & estExt_Genemark1.C_230094 & 339122 & $\begin{array}{l}\text { MQLTSIAIILFAAMGAIANPITAEANNLVAREEELSKYGGECSVEHNTCTYLK } \\
\text { GGKDHIVSCPSAANLRCKTERHHCEYDEHHKTVDCQTPV }\end{array}$ & n.a. & JGI \\
\hline $\begin{array}{l}\text { Aspergillus steynii IBT } 23096 \\
\text { (CBS 112812) }\end{array}$ & e_gw1.9.1205.1 & 368051 & $\begin{array}{l}\text { MKFLSIASLSLILFTAMGVLGSPIESEALASNDLDARDEAGILIKYPGTCSKKN } \\
\text { NNCRYKSQNGRTAFCKCKFKKCAKDGNKCHFDSYNQDCQCI }\end{array}$ & $\begin{array}{l}\text { Eredet: Karnataka, } \\
\text { Chamumdeshuran Estata, } \\
\text { Giris }\end{array}$ & JGI \\
\hline Aspergillus tubingensis & estExt_Genemark1.C_6_t10079 & 202739 & $\begin{array}{l}\text { MQLTSIAIILFAAMGAIANPIAAESDDLLARDAQLSKYGGECSLEHNTCTYRK } \\
\text { DGKNHVVSCPSAANLRCKTDRHHCEYDDHHKTVDCQTPV }\end{array}$ & n.a. & JGI \\
\hline $\begin{array}{l}\text { Beauveria bassiana } \\
\text { ARSEF } 2860\end{array}$ & antifungális protein & EJP62050 & $\begin{array}{l}\text { MQIISIALSLLAATGAVAAATPEQFEARDGAGAMIKYHGICTKAKNECKFKGQ } \\
\text { NGRDTFVKCPNFANKRCTKDYNECSYDSVSRAVVCH }\end{array}$ & Eredet: Kína & NCBI \\
\hline $\begin{array}{l}\text { Fusarium avenaceum } \\
\text { SZMC } 11044\end{array}$ & antifungális protein & CAR79018 & $\begin{array}{l}\text { MQFSTIIPLFVAAMGVVATPVNSPAQELDARGNLFPRLEYWGKCTKAENRCK } \\
\text { YKNDKGRDVLQNCPKFDNKKCTKDGNSCKWDSATKALTCY }\end{array}$ & n.a. & NCBI \\
\hline Fusarium boothi SZMC 3855 & antifungális protein & CAR79009 & $\begin{array}{l}\text { MQFSTIIPLFVAAMGVVATPVNSPAQELDARGNLFPRLEYWGKCTKAENRCK } \\
\text { YKNDKGKDVLQNCPKFDNKKCTKDGNSCKWDSASKALTCY }\end{array}$ & n.a. & NCBI \\
\hline Fusarium boothi SZMC 3856 & antifungális protein & E1UGW9 & $\begin{array}{l}\text { MQFSAIIPLFVAAMGVVATPVNSPAQELDARGNLFPRLEYWGKCTKAENRCK } \\
\text { YKNDKGKDVLQNCPKFDNKKCTKDGNSCKWDSASKALTCY }\end{array}$ & n.a. & UniProtKB \\
\hline Fusarium cerealis SZMC 11048 & antifungális protein & CAR79014 & $\begin{array}{l}\text { MQFSTIIPLFLAVMGVVATPVNSPAQELDARGNLFPRLEYWGKCTKAENRCK } \\
\text { YKNDKGKDVLQNCPKFDNKKCTKDGNSCKWDSASKALTCY }\end{array}$ & n.a. & NCBI \\
\hline $\begin{array}{c}\text { Fusarium fujikuroi IMI } 58289 \\
\text { (CBS } 195.34 \text { / IMI } 58289 \text { / } \\
\text { NRRL A-6831) }\end{array}$ & antifungális proteinnel kapcsolatos & S0ELR5 & $\begin{array}{l}\text { MQFSAITLLLVAAVGVAATPIDSPVMALDARGNLEKRLDYKGTCTKSSNTCR } \\
\text { YKGPNGRTAFKKCGTFANQKDGAPCVWQSDKGVGGKITCK }\end{array}$ & $\begin{array}{l}\text { Eredet: Taiwan } \\
\text { Izoláció: Saccharum } \\
\text { officinalum }\end{array}$ & UniProtKB \\
\hline Fusarium poae SZMC 11045 & antifungális protein & CAR79017 & $\begin{array}{l}\text { MQFSTIIPLFLAVMGVVATPVNSPAQELDARGNLFPRLEYWGKCTKAENRCK } \\
\text { YKNDKGKDVLQNCPKFDNKKCTKDGNSCKWDSASKALPCY }\end{array}$ & n.a. & NCBI \\
\hline $\begin{array}{l}\text { Fusarium pseudograminearum } \\
\qquad \text { CS3096 }\end{array}$ & nem jellemzett protein & K3U8M5 & $\begin{array}{l}\text { MQFSTILPLFVAAMGIVATPVNSPAQELDARGNLLPRLEYWGKCTKAENRCK } \\
\text { YKNDKGRDVLQNCPKFDNKKCTKDGNSCKWDSASKALTCY }\end{array}$ & $\begin{array}{l}\text { Eredet: Ausztrális, Moree, } \\
\text { Northern New South Wales } \\
\text { Izoláció: búzakalász }\end{array}$ & UniProtKB \\
\hline $\begin{array}{l}\text { Fusarium verticillioides } 7600 \\
\text { (strain M3125 / FGSC 7600) }\end{array}$ & nem jellemzett protein & W7MV04 & $\begin{array}{l}\text { MQFSTITLLLLASTGVAATPIYSPAMPLDARRNLEKRLEYKGTCTKSSNTCRY } \\
\text { KGPNGRTTFKKCGTFANQKCTKDGAPCVWESEKGVGGKVTCK }\end{array}$ & n.a. & UniProtKB \\
\hline
\end{tabular}




\begin{tabular}{|c|c|c|c|c|c|}
\hline Monascus pilosus BCRC38072 & MAFP1 & V5NDL2 & $\begin{array}{l}\text { MQFTKIAIFLFAAMGAVANPIAAESGDLDVRDVQLSKYGGECSLQHNTCTYL } \\
\text { KGGKNQVVHCGSAANQKCKSDRHHCEYDEHHKTVNCQTPV }\end{array}$ & n.a. & UniProtKB \\
\hline Monascus ruber NRRL 1597 & gm1.5425_g & 472164 & $\begin{array}{l}\text { MKLTSLGLLALAAIGAVATPIDPDSQSLGVRNEDSVLIKYDGTCSKKDNSCKY } \\
\text { KSQDGKTAFCHCKFKMCAKDGDKCHFDSYKSECICS }\end{array}$ & n.a. & JGI \\
\hline $\begin{array}{c}\text { Neosartrorya fischeri NRRL } 181 \\
\text { (strain ATCC } 1020 \text { / DSM } 3700 \text { / } \\
\text { CBS } 544.65 \text { / FGSC A1164 / } \\
\text { JCM } 1740 \text { / NRRL } 181 \text { / WB } \\
\text { 181) }\end{array}$ & Neosartorya fischeri antifungális protein & D4YWE1 & $\begin{array}{l}\text { MQITKISLFLFVGIGVVASPIHAESDGLNARAVNAADLEYKGECFTKDNTCKY } \\
\text { KIDGKTYLAKCPSAANTKCEKDGNKCTYDSYNRKVKCDFRH }\end{array}$ & $\begin{array}{l}\text { Izoláció: Étel, konzerv } \\
\text { gyümölcs (alma) }\end{array}$ & UniProtKB \\
\hline Neosartorya fischeri NRRL 4585 & antifungális protein & - & $\begin{array}{l}\text { MQITKISLFLFAGIGVVASPIHAESDGLNARAVNAADLEYKGECFTKDNTCKY } \\
\text { KIDGKTYLAKCPSAANTKCEKDGNKCTYDSYNRKVKCDFRH }\end{array}$ & $\begin{array}{l}\text { Eredet: Haiti } \\
\text { Izoláció: babbal beültetett } \\
\text { terület talaja }\end{array}$ & - \\
\hline $\begin{array}{l}\text { Neosartorya spathulate } \\
\text { SZMC } 1380\end{array}$ & antifungális protein & - & $\begin{array}{l}\text { MQITKISLFLFVGVGVVASPIHAESDGLNARAVNAADLEYKGECFTKDNTCK } \\
\text { YKIDGKTYLAKCPSAANTKCEKDGNKCTYDSYNRKVKCDFRH }\end{array}$ & n.a. & - \\
\hline Penicillium chrysogenum & gm1.5472_g & 5484 & $\begin{array}{l}\text { MHITSIAIVFFAAMGAVASPIATESDDLDARDVQLSKFGGECSLKHNTCTYLK } \\
\text { GGKNHVVNCGSAANKKCKSDRHHCEYDEHHKRVDCQTPV }\end{array}$ & n.a. & JGI \\
\hline Penicillium chrysogenum Q176 & antifungális protein & Q01701 & $\begin{array}{l}\text { MQITTVALFLFAAMGGVATPIESVSNDLDARAEAGVLAKYTGKCTKSKNECK } \\
\text { YKNDAGKDTFIKCPKFDNKKCTKDNNKCTVDTYNNAVDCD }\end{array}$ & n.a. & UniProtKB \\
\hline Penicillium chrysogenum $\mathrm{RP} 42 \mathrm{C}$ & antifungális protein & D0EXD3 & $\begin{array}{l}\text { MQITSIAIVFFAAMGAVANPIARESDDLDARDVQLSKFGGECSLKHNTCTYLK } \\
\text { GGKNHVVNCGSAANKKCKSDRHHCEYDEHHKRVDCQTPV }\end{array}$ & Izoláció: száraz-párolt sonka & UniProtKB \\
\hline $\begin{array}{l}\text { Penicillium digitatum } \\
\text { CECT } 20795 \text { (Pd1) }\end{array}$ & antifungális protein Afp & K9FEL1 & $\begin{array}{l}\text { MQITSIAIILFTAMGAVANPIATASDDLDARDVQLSKYGGQCSLKHNTCTYLK } \\
\text { GGRNVIVNCGSAANKRCKSDRHHCEYDEHHRRVDCQTPV }\end{array}$ & $\begin{array}{l}\text { Eredet: Spanyolország, } \\
\text { Valencia } \\
\text { Izoláció: fertőzött grapefruit }\end{array}$ & UniProtKB \\
\hline \multirow{2}{*}{$\begin{array}{l}\text { Penicillium expansum } \\
\text { ATCC } 24692\end{array}$} & estExt_Genemark1.C_6_t10265 & 444546 & $\begin{array}{l}\text { MQITRIAIFLFAAMGAVASPIVAESRDVDAQALSKYGGECSKEHNTCTYRKD } \\
\text { GKDHIVKCPSADNKKCKTDRHHCEYDGHHKTVDCQTPV }\end{array}$ & n.a. & JGI \\
\hline & $\begin{array}{c}\text { fgenesh1_kg.4_\#_1163_\#_Locus5213v1rpk } \\
\text { m9.21 }\end{array}$ & 376451 & $\begin{array}{l}\text { MQITKIALFLFAAMGAVASPIEAEAESGINARAENGANVLYTGQCFKKDNICK } \\
\text { YKVNGKQNIAKCPSAANKRCEKDKNKCTFDSYDRKVTCDFRK }\end{array}$ & n.a. & JGI \\
\hline Penicillium expansum & antifungális protein & A0A0A2K0J0 & $\begin{array}{l}\text { MQITRIAIFLFAAMGAVASPIVAESRDVDAQALSKYGGECSKEHNTCTYRKD } \\
\text { GKDHIVKCPSADNKKCKTDRHHCEYDDHHKTVDCQTPV }\end{array}$ & n.a. & UniProtKB \\
\hline
\end{tabular}




\begin{tabular}{|c|c|c|c|c|c|}
\hline Penicillium italicum & antifungális protein & A0A0A2KW66 & $\begin{array}{l}\text { MQITRIAIFFFAAMGAVANPITNDLNAQALSKYGGECSKEHNTCTYRKDGKD } \\
\text { HKVKCPSADNLKCKTDRHHCEYDDHHKKVDCQTPV }\end{array}$ & n.a. & UniProtKB \\
\hline $\begin{array}{l}\text { Penicillium oxalicum } 114-2 \\
\quad \text { (CGMCC 5302) }\end{array}$ & nem jellemzett protein & S7ZGG3 & $\begin{array}{l}\text { MQITKISLFLFAAMGAVASPIDAESDGLNARAVNAANIQYTEKCYTKDNNCK } \\
\text { YENDGKTHFVKCPSAANTKCEKDGNRCTHESYNGNVKCDFRH }\end{array}$ & Eredet: Kína & UniProtKB \\
\hline $\begin{array}{l}\text { Penicillium oxalicum (strain 114- } \\
\qquad 2 \text { / CGMCC } 5302 \text { ) }\end{array}$ & nem jellemzett protein & S8AKE6 & $\begin{array}{l}\text { MQFSSLSLVFLAVIGAIANPIAVDSELENRDVQLSKYGGECNLKTNACRYTKG } \\
\text { GKSVFVPCGTAANKRCKSDRHHCEYDEHHKRVDCQTPV }\end{array}$ & n.a. & UniProtKB \\
\hline $\begin{array}{c}\text { Penicillium raistrickii ATCC } \\
10490 \\
\text { NRRL } 2039 \text { (CBS 261.33, FRR } \\
\text { 1044, IBFM(MGU) F183, IFO } \\
\text { 6104, IMI 40221, LSHB BB100, } \\
\text { MWi 477, NRRL 1044, QM } \\
\text { 1936, VKM F-337) }\end{array}$ & gm1.10905_g & 364170 & $\begin{array}{l}\text { MQITSIAIALFAAMVVVANPIATDSDSLGARDAQLSKYGGECSLQHNTCTYRK } \\
\text { DGKNHVVNCPTATNKKCKTDRHHCEYDDHHKTVDCQTPV }\end{array}$ & n.a. & JGI \\
\hline Pyrenophora teres $f$. teres $0-1$ & feltételezett, nem jellemzett protein & E3RKD1 & $\begin{array}{l}\text { MQFTTATLIFLTALNAVATPIDSASVPTEVRLKFTGTCTKSTDQCSFTRNGKTS } \\
\text { ISKCSTATAVNYRCTKDKNSCTYDDVDGKTRCT }\end{array}$ & n.a. & UniProtKB \\
\hline $\begin{array}{l}\text { Pyrenophora tritici-repentis Pt- } \\
\qquad 1 \mathrm{C}-\mathrm{BFP}\end{array}$ & nem jellemzett protein & B2W0K7 & $\begin{array}{l}\text { MQFTTATLLFLTAITVVASPVESVPGDIRIKFDGKCTKSTDQCSFTRNGKTSISK } \\
\text { CSTATAVNYRCTKDKNPCTYDDVDGKTRCT }\end{array}$ & n.a. & UniProtKB \\
\hline \multicolumn{6}{|c|}{ BP-klaszter } \\
\hline $\begin{array}{l}\text { Apiospora montagnei } \\
\text { NRRL } 25634\end{array}$ & gm1.11972_g & 114284 & $\begin{array}{l}\text { MQFSTVFTTLLAAVAVTASAVPDVEARAPEIESIPELQARDTCGAGYGGDQR } \\
\text { RTNSPCKSSNGDRHFCGCDRTGIVECKRGKWTEIKDCRRASCHGTNQGAAVC }\end{array}$ & n.a. & JGI \\
\hline $\begin{array}{l}\text { Aspergillus campestris } \\
\text { IBT } 28561\end{array}$ & gm1.5151_g & 318976 & $\begin{array}{l}\text { MKLIAIVCTLMAAAAVSASTIEARDTCGAGYGGDQRRTNSPCAASNGDRHFC } \\
\text { GCDRTGVVECKGGKWTEVKDCGRGTCHGGNQGAAQC }\end{array}$ & n.a. & JGI \\
\hline $\begin{array}{l}\text { Aspergillus fumigatus A1163 } \\
\text { (strain CEA10 / CBS } 144.89 \text { / } \\
\text { FGSC A1163) }\end{array}$ & CADAFUBT00009588m.01 & 108562 & $\begin{array}{l}\text { MKFTALLCTLIAATAVSASTVPRDEFQIQDTCGSGYGGDQRRTNRLVWYVNP } \\
\text { SQLEDETSFAHGYSFKKVECRNGRWTEIQDCHASTCHGTNDGAARC }\end{array}$ & n.a. & JGI \\
\hline $\begin{array}{l}\text { Aspergillus novofumigatus (MB } \\
\text { 500297) }\end{array}$ & fgenesh1_pm.3_\#_1203 & 459645 & $\begin{array}{l}\text { MKFTALLCTLMAATAVSASTLPRGEFQVQDTCGAGYGGDQRRTNSPCNASN } \\
\text { GDRHFCGCDRTGVVECRGGKWTEIQDCHASTCHGTNDGAARC }\end{array}$ & n.a. & JGI \\
\hline
\end{tabular}




\begin{tabular}{|c|c|c|c|c|c|}
\hline Aspergillus sydowii & gm1.870_g & 84187 & $\begin{array}{l}\text { MKFTSVILTLLAAAAVTAAPSPELEVRDTCGAGYGGDQRRTNSPCNASNGDR } \\
\text { HFCGCDRTGVDVVAD }\end{array}$ & n.a. & JGI \\
\hline Aspergillus versicolor & gm1.2374_g & 79906 & $\begin{array}{l}\text { MKFTSLILTLMAAAAVTAAPSPELEVRDTCGPGYGGDQRRTNSPCNASNGDR } \\
\text { HFCGCDRTGVVECRGGRWTEIRDCGRGTCHGGNDGGAVC }\end{array}$ & n.a. & JGI \\
\hline $\begin{array}{c}\text { Caetomium globosum } \\
\text { CBS } 148.51 \\
\text { (strain ATCC } 6205 \text { / CBS } 148.51 \\
\text { / DSM } 1962 \text { / NBRC } 6347 \text { / } \\
\text { NRRL 1970) }\end{array}$ & nem jellemzett protein & Q2GQ49 & $\begin{array}{l}\text { MKVSAIVCTLMAAVAVTASAAPNVQARDTCGAGYGGDQRRTNSPCQSSNG } \\
\text { DRHFCGCDRTGVVECRGGKWTEIRDCGSGTCHGGNDGGAVC }\end{array}$ & $\begin{array}{l}\text { Eredet: USA, Washington } \\
\text { DC, Columbia } \\
\text { Izoláció: tárolt pamut }\end{array}$ & UniProtKB \\
\hline Eutypa lata UCREL1 & UCREL1_11172m.01 & 6607 & $\begin{array}{l}\text { MKFTAILFTLAAAVAVNASATPQLETRDTCGAGYGGDQRRTNSPCESSNGDR } \\
\text { HFCGCDRTGVVQCIGGTWSEIQDCHSGTCHGGNDGGAVC }\end{array}$ & n.a. & JGI \\
\hline $\begin{array}{l}\text { Myceliophthora heterothallica } \\
\text { CBS } 203.75\end{array}$ & estExt_Genewise1Plus.C_8_t30252 & 736991 & $\begin{array}{l}\text { MKVTAILCTLIAAVVVGASTIPEIQARDTCGAGYGGDQRRTNSPCQASNGDR } \\
\text { HFCGCDRTGVVECRNGR WTEIRDCGSSTCHGTNDGGAVC }\end{array}$ & $\begin{array}{l}\text { Eredet: USA, Indiana, } \\
\text { Bloomington } \\
\text { Izoláció: talaj }\end{array}$ & JGI \\
\hline $\begin{array}{l}\text { Neosartorya botucatensis } \\
\quad \text { SZMC } 2035\end{array}$ & antifungális protein & - & $\begin{array}{l}\text { MKLPALLCTLMAATAVSASTLPRGEFQVQDTCGAGYGGDQRRTNSPCNASN } \\
\text { GDRHFCGCDRTGVVECRGGRWTEIQDCHASTCHGTNDGAARC }\end{array}$ & n.a. & - \\
\hline $\begin{array}{l}\text { Neosartorya fennelliae } \\
\quad \text { SZMC } 1378\end{array}$ & antifungális protein & - & $\begin{array}{l}\text { MKFPALLCTLMAAAAVSASTVPRAVLDTCGAGYGGDQRRTNSPCEASNGDR } \\
\text { HFCGCDRTDVVECQGGYWREIQDCRAGTCHGTNDGAAGC }\end{array}$ & n.a. & - \\
\hline $\begin{array}{l}\text { Neosartorya fennelliae } \\
\quad \text { SZMC } 1379\end{array}$ & antifungális protein & - & $\begin{array}{l}\text { MKFPALLCTLMAAAAVSASTVPRAVLDTCGAGYGGDQRRTNSPCEASNGDR } \\
\text { HFCGCDRTDVVECQGGYWREIQDCGAGTCHGTNDGAAGC }\end{array}$ & n.a. & - \\
\hline $\begin{array}{l}\text { Neosartorya fennelliae } \\
\text { SZMC } 2044\end{array}$ & antifungális protein & - & $\begin{array}{l}\text { MKFPALLCTLMAAAAVSALTVPRAVLDTCGAGYGGDQRRTNSPCEASNGDR } \\
\text { HFCGCDRTDVVECQGGYWREIQDCGAGTCHGTNDGAAGC }\end{array}$ & n.a. & - \\
\hline $\begin{array}{l}\text { Neosartorya fennelliae } \\
\quad \text { SZMC } 2045\end{array}$ & antifungális protein & - & $\begin{array}{l}\text { MKFTALLCTLMAATAVSASTLPRGEFQVQDTCGAGYGGDQRRTNSPCNASN } \\
\text { GDRHFCGCDRTGVVECRGGR WTEIQDCHASTCHGTNDGAAGC }\end{array}$ & n.a. & - \\
\hline $\begin{array}{l}\text { Neosartorya fennelliae } \\
\quad \text { SZMC } 22337\end{array}$ & antifungális protein & & $\begin{array}{l}\text { MKFPALLCTLMAAAAVSASTVPRAVLDTCGAGYGGDQRRTNSPCEASNGDR } \\
\text { HFCGCDRTDVVECQGGYWREIQDCGAATCHGTNDGARGC }\end{array}$ & n.a. & - \\
\hline $\begin{array}{l}\text { Neosartorya fennelliae } \\
\text { SZMC } 22338\end{array}$ & antifungális protein & - & $\begin{array}{l}\text { MKFQALLCTLMAAAAVSASTVPRAVLDTCGAGYGGDQRRTNSPCEASNGDR } \\
\text { HFCGCDRTDVVECQGGYWREIQDCGAATCHGTNDGAAGC }\end{array}$ & n.a. & - \\
\hline
\end{tabular}




\begin{tabular}{|c|c|c|c|c|c|}
\hline $\begin{array}{l}\text { Neosartorya ferenczii } \\
\text { NRRL } 4179\end{array}$ & antifungális protein & - & $\begin{array}{l}\text { MKFSALLCTLMAATAVSASTLPRGEFQVQDTCGAGYGGDQRRTNSPCNASN } \\
\text { GDRHFCGCDRTGVVECRGGR WTEIQDCHASTCHGTNDGAAGC }\end{array}$ & $\begin{array}{l}\text { Eredet: Ausztrália } \\
\text { Izoláció: talaj }\end{array}$ & - \\
\hline $\begin{array}{c}\text { Neosartorya fischeri NRRL } 181 \\
\text { (strain ATCC } 1020 \text { / DSM } 3700 \text { / } \\
\text { CBS } 544.65 \text { / FGSC A1164 / } \\
\text { JCM } 1740 \text { / NRRL } 181 \text { / WB } \\
\text { 181) }\end{array}$ & nem jellemzett protein & A1DKX1 & $\begin{array}{l}\text { MKFTALLCTLMAATAVSASTVPRDEFQIQDTCGAGYGGDQRRTNSPCNASN } \\
\text { GDRHFCGCDRTGVVECRGGRWTEIQDCRASTCHGTNDGAARC }\end{array}$ & $\begin{array}{l}\text { Izoláció: Étel, konzerv } \\
\text { gyümölcs (alma) }\end{array}$ & UniProtKB \\
\hline Neosartorya fischeri A-7223 & antifungális protein & - & $\begin{array}{l}\text { MKFSALLCTLMAATAVSASTVPRDEFQIQDTCGAGYGGDQRRTNSPCNASNG } \\
\text { DRHFCGCDRTGVVECRGGRWTEIQDCRASTCHGTNDGAARC }\end{array}$ & n.a. & - \\
\hline Neosartorya fischeri NRRL 4075 & antifungális protein & - & $\begin{array}{l}\text { MKLSTLLCTLMAATAVSASTVPRDEFQIQDTCGAGYGGDQRRTNSPCNASNG } \\
\text { DRHFCGCDRTGVVECRGGRWTEIQDCRASTCHGTNDGAAGC }\end{array}$ & $\begin{array}{l}\text { Eredet: Egyesült Királyság } \\
\text { Izoláció: kerti talaj }\end{array}$ & - \\
\hline Neosartorya fischeri NRRL 4161 & antifungális protein & - & $\begin{array}{l}\text { MKFTALLCTLMAATAVSASTVPRDEFQIQDTCGAGYGGDQRRTNSPCNASN } \\
\text { GDRHFCGCDRTGVVECRGGRWTEIQDCRASTCHGTNDGAAGC }\end{array}$ & n.a. & - \\
\hline $\begin{array}{l}\text { Neosartorya spinosa } \\
\quad \text { NRRL } 3435\end{array}$ & antifungális protein & - & $\begin{array}{l}\text { MKFSALLCTLMAAAAVSASTVPRGEFQVQDTCGAGYGGDQRRTNSPCNASN } \\
\text { GDRHFCGCDRTGVVECRGGRWTEIRDCHASTCHGTNDGAARC }\end{array}$ & n.a. & - \\
\hline $\begin{array}{l}\text { Penicillium brevicompactum } \\
1011305\end{array}$ & gm1.665_g & 53502 & $\begin{array}{l}\text { MKITALLYTLTAATAVSAAAVAERDTLGGLEARDTCGSGYNVDQRRTNSGC } \\
\text { KAGNGDRHFCGCDRTGVVECKGGKWTEVQDCGSSSCKGTSNGGATC }\end{array}$ & n.a. & JGI \\
\hline $\begin{array}{l}\text { Penicillium brevicompactum } \\
\text { AgRF18 }\end{array}$ & gm1.2484_g & 348372 & $\begin{array}{l}\text { MKITALLYTLMAATAVSAAAVAERDTLGGLEARDTCGSGYNVDQRRTNSGC } \\
\text { KAGNGDRHFCGCDRTGVVECKGGKWTEVQDCGSSSCKGTSNGGATC }\end{array}$ & n.a. & JGI \\
\hline $\begin{array}{l}\text { Penicillium brevicompactum } \\
\text { Dierckx }\end{array}$ & bubble protein & G5DC88 & $\begin{array}{l}\text { MKITALFYTLMAATAVSAAAVAERDTLGGLEARDTCGSGYNVDQRRTNSGC } \\
\text { KAGNGDRHFCGCDRTGVVECKGGKWTEVQDCGSSSCKGTSNGGATC }\end{array}$ & n.a. & UniProtKB \\
\hline $\begin{array}{c}\text { Penicillium chrysogenum } \\
\text { (rubens) Wisconsin 54-1255 } \\
\text { (strain ATCC 28089 / DSM } 1075 \\
\text { / NRRL 1951) }\end{array}$ & Pc21g12970 protein & B6HMF2 & $\begin{array}{l}\text { MKVTALLFTLMAATAVSASVLDTRDTCGGGYGVDQRRTNSPCQASNGDRHF } \\
\text { CGCDRTGIVECKGGKWTEIQDCGGASCRGVSQGGARC }\end{array}$ & $\begin{array}{l}\text { Eredet: USA, Illinois, Peoria } \\
\text { Izoláció: étel, gyümölcs } \\
\text { (kantalup dinnye) }\end{array}$ & UniProtKB \\
\hline $\begin{array}{l}\text { Penicillium expansum } \\
\quad \text { ATCC } 24692\end{array}$ & estExt_Genemark1.C_3_t40302 & 441362 & $\begin{array}{l}\text { MKVTAILFTLMAATAVSASVLDKRDTCGAGYDPAQRRTNSPCQASNGDRHF } \\
\text { CGCDRTGIVECKGGKWTEIQDCGRNSCHGGTEGGAKC }\end{array}$ & n.a. & JGI \\
\hline
\end{tabular}




\begin{tabular}{|c|c|c|c|c|c|}
\hline Penicillium expansum & nem jellemzett protein & A0A0A2JEC9 & $\begin{array}{l}\text { MKVTAILFTLMAATAVSASVLDKRDTCGAGYDPAQRRTNSPCQASNGDRHF } \\
\text { CGCDRTGIIMFANIYFRDKVECKGGKWTEIQDCGRNSCHGGTEGGAKC }\end{array}$ & n.a. & UniProtKB \\
\hline $\begin{array}{l}\text { Penicillium lanosocoeruleum } \\
\text { ATCC } 48919 \\
\text { (Penicillium aurantiogriseum } \\
\text { var. viridicatum (Westling)) }\end{array}$ & $\begin{array}{c}\text { fgenesh1_kg.7_\#_91_\#_Locus9265v1rpkm1. } \\
74\end{array}$ & 385694 & $\begin{array}{l}\text { MKVTSFFLTIMAATAATASVLNTRDTCGSGYAPEQRRTNSPCQASNGDRHFC } \\
\text { GCDRTGVVQCKGGKWTEVQDCGKNSCHGGIEGGAKC }\end{array}$ & n.a. & JGI \\
\hline Penicillium roqueforti & bubble protein & W6QPZ7 & $\begin{array}{l}\text { MKVTAILFTLMAATAVNASVLDKRDTCGSGYDPAQRRTNSPCQASNGDRHF } \\
\text { CGCDRTGIVECKGGKWTEVQDCHTNSCHGGTEGGAKC }\end{array}$ & n.a. & UniProtKB \\
\hline $\begin{array}{l}\text { Thermothelomyces thermophila } \\
\text { ATCC } 42464 \\
\text { (strain ATCC } 42464 \text { / BCRC } \\
31852 \text { / DSM 1799) }\end{array}$ & nem jellemzett protein & G2QMD8 & $\begin{array}{l}\text { MKVTAILCTLVAAAVVGASTIPEIPEIQARDTCGAGYGGDQRRTNSPCQASNG } \\
\text { DRHFCGCDRTGVVECRNGKWTEIRDCRSATCHGTNDGGAVC }\end{array}$ & Izoláció: papír komposzt & UniProtKB \\
\hline $\begin{array}{l}\text { Thielavia antarctica } \\
\qquad \text { CBS } 123565\end{array}$ & $\begin{array}{c}\text { fgenesh1_kg.1_\#_824_\#_Locus1038v1rpkm } \\
196.06\end{array}$ & 438289 & $\begin{array}{l}\text { MKFTAILFTLAAAVAVNASAVPGAEGIQARDTCGSGYGGDQRRTNSPCNASN } \\
\text { GDRHFCGCDRTGVVECRRGKWTEIRDCGRGTCHGGNDGGAVC }\end{array}$ & $\begin{array}{l}\text { Eredet: Antarktisz } \\
\text { Izoláció: Usnea cf.aurantio- } \\
\text { atra }\end{array}$ & JGI \\
\hline
\end{tabular}

Az adatbázisok rövidítése: NCBI: National Center for Biotechnology Information; Bethesda, MD, USA; JGI: Joint Genome Institute; Walnut Creek, CA,

USA; UniProtKB: Universal Protein Knowledgebase. A törzsgyüjteményi azonosítószám és a fehérjeazonosító a táblázatban látható. Piros színnel jelöltük a preproszekvenciát. n.a.: nincs adat. 